\title{
THE POTENTIAL NEED FOR FUSION IN THE U.S. ENERGY SYSTEM
}

\author{
E. BEARDSWORTH AND J. POWELL
}

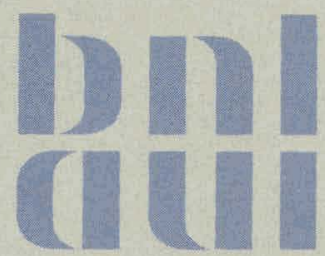

September 1977

DEPARTMENT OF NUCLEAR ENERGY

BROOKHAVEN NATIONAL LABORATORY ASSOCIATED UNIVERSITIES, INC. UNDER CONTRACT NO. EY-76-C-02-0016 WITH THE UNITED STATES DEPARTMENT OF ENERGY 


\section{DISCLAIMER}

This report was prepared as an account of work sponsored by an agency of the United States Government. Neither the United States Government nor any agency Thereof, nor any of their employees, makes any warranty, express or implied, or assumes any legal liability or responsibility for the accuracy, completeness, or usefulness of any information, apparatus, product, or process disclosed, or represents that its use would not infringe privately owned rights. Reference herein to any specific commercial product, process, or service by trade name, trademark, manufacturer, or otherwise does not necessarily constitute or imply its endorsement, recommendation, or favoring by the United States Government or any agency thereof. The views and opinions of authors expressed herein do not necessarily state or reflect those of the United States Government or any agency thereof. 


\section{DISCLAIMER}

Portions of this document may be illegible in electronic image products. Images are produced from the best available original document. 


\title{
THE POTENTIAL NEED FOR FUSION IN THE U.S. ENERGY SYSTEM
}

\author{
E. Beardsworth AND J. PoWell
}

This report was prepared as an account of work
sponsored by the United States Government. Neither the
United States nor the United States Department of
Energy, nor any of their employees, nor any of their
contractors, subcontractors, or their employees, makes
any warranty, express or implied, or assumes any legal
liability or responsibitity for the accuracy, completeness
or usefulness of any information, apparatus, product or
process disclosed, or represents that its use would not
infringe privately owned rights.

DEPARTMENT OF NUCLEAR ENERGY

BROOKHAVEN NATIONAL LABORATORY

UPTON, NEW YORK 11973 
This report was prepared as an account of work sponsored by the United States Government. Neither the United States nor the United States Department of Encrgy (DOE), nor any of their employees, nor any of their contrastors, suhrontractors, or their employees, makes any warranty, express or implied, or assumes any legal liability

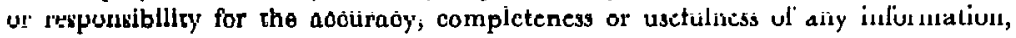
apparatus, product or process disclosed, or represents that its use would not infringe privately owned rights.

Printed in the United States of America

Available from

National Technical Information Service

U.S. Department of Commerce

5285 Port Royal Road

Springfield, VA 22161

Price: Printed Copy $\$ 8.00$; Microfiche $\$ 3.00$

November 1977

250 copies 
LIST OF TABLES .

vi

LIST OF FIGURES

vii

ABSTRACT

$1 x$

PREFACE

$\mathbf{x}$

SUMMARY AND CONCLUSIONS $\ldots \ldots \ldots \ldots \ldots \ldots \ldots \ldots \ldots \ldots \ldots \ldots \ldots$

1.

INTRODUCTION $\ldots \ldots \ldots \ldots \ldots \ldots \ldots \ldots \ldots \ldots \ldots \ldots \ldots \ldots \ldots \ldots \ldots \ldots \ldots$

A. Background and Purpose ..................... 1

B. Approach $\ldots \ldots \ldots \ldots \ldots \ldots \ldots \ldots \ldots \ldots \ldots \ldots \ldots \ldots \ldots \ldots \ldots \ldots \ldots$

c. Methodology ............................ 3

2.

APPROACH AND METHODOLOGY $\ldots \ldots \ldots \ldots \ldots \ldots \ldots \ldots \ldots \ldots \ldots \ldots \ldots \ldots \ldots$

A. Introduction $\ldots \ldots \ldots \ldots \ldots \ldots \ldots \ldots \ldots \ldots \ldots \ldots \ldots \ldots \ldots$

B. Long-Range Benefits $\ldots \ldots \ldots \ldots \ldots \ldots \ldots \ldots \ldots \ldots \ldots \ldots$

C. Time Scale and Uncertainty .................. 10

D. Major Areas of Uncertainty .................. 11

Total Energy Resource Consumption .............. 11

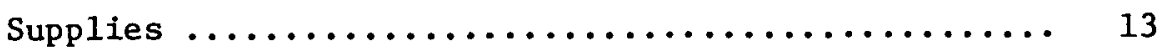

Rate Constraints ........................ 16

E. The Model and Scenarios .................... 17

Scenarios ................................ 20

Sample TPRESG Output ..................... 21

F. Cost and Environmental Coefficients ............ 24

Fuston Capital Cost and Learning Curves .......... 24

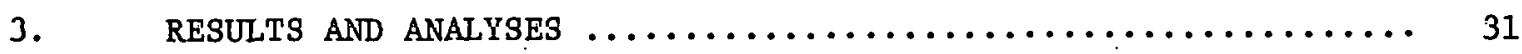

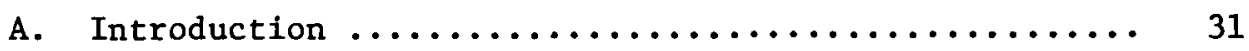


B. Resource Trade-offs and Cost/Benefit .......... 32

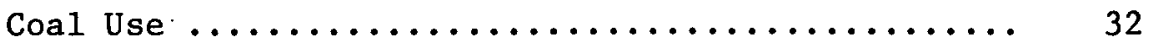

Cost $\ldots \ldots \ldots \ldots \ldots \ldots \ldots \ldots \ldots \ldots \ldots \ldots \ldots \ldots \ldots \ldots \ldots \ldots \ldots \ldots \ldots, 37$

Annual Cost Curves and Discounting $\ldots \ldots \ldots \ldots \ldots . . . .37$

C. Drastic Limits ....................... 40

D. Basic Long-Range Alternatives ............. 40

E. Early Implementation of Fusion $\ldots \ldots \ldots \ldots \ldots \ldots \ldots$. 46

F. Coot Ecnoitivity $\ldots \ldots \ldots \ldots \ldots \ldots \ldots \ldots \ldots \ldots \ldots$ 16

CTR Capital Cost Learning Curve ............ 50

4. PROJECTIONS OF TOTAL ENERGY CONSUMPTION $\ldots \ldots \ldots \ldots \ldots \ldots \ldots \ldots$

A. The Twentiety Century $\ldots \ldots \ldots \ldots \ldots \ldots \ldots \ldots \ldots \ldots$

B. The Twenty-first Century .................... 64

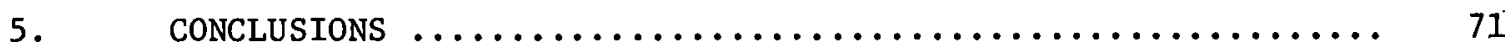

Total Resource Consumption ............... 73

APPENDICES $\ldots \ldots \ldots \ldots \ldots \ldots \ldots \ldots \ldots \ldots \ldots \ldots \ldots \ldots \ldots \ldots \ldots \ldots \ldots \ldots \ldots$

A. Cost/Benefit Analysis $\ldots \ldots \ldots \ldots \ldots \ldots \ldots \ldots \ldots \ldots$

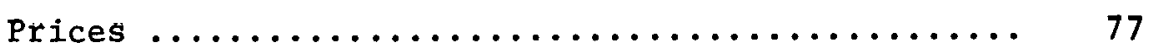

The Discount Rate ...................... 79

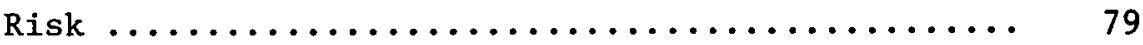

Social Discount Rate .................... 80

For low discount rates $\ldots \ldots \ldots \ldots \ldots \ldots \ldots \ldots, 80$

For high rates $\ldots \ldots \ldots \ldots \ldots \ldots \ldots \ldots \ldots \ldots, 81$

B. Minimun Long-range Net Benefits ............ 83

C. Time Phased Reference Energy System Generator .... 87

Bacic Structurc ....................... 87

Initial Data Set $\ldots \ldots \ldots \ldots \ldots \ldots \ldots \ldots \ldots \ldots \ldots, 87$ 
Activity Level Changes $\ldots \ldots \ldots \ldots \ldots \ldots \ldots \ldots$

Time Dependence $. . \ldots \ldots \ldots \ldots \ldots \ldots \ldots \ldots \ldots \ldots \ldots . \ldots . \ldots . \ldots$

Interpolation $\ldots \ldots \ldots \ldots \ldots \ldots \ldots \ldots \ldots \ldots \ldots \ldots$

Calculation of Effects $\ldots \ldots \ldots \ldots \ldots \ldots \ldots \ldots \ldots$

Cost Calculation ...................... 97

Health and Environmental - Emissions and

Effects ............................ 98

D. Scenario Printouts ..................... 105 
TABLE $2-1 \quad$ Present Value of Future Benefits $\ldots \ldots \ldots \ldots \ldots \ldots \ldots$. 9

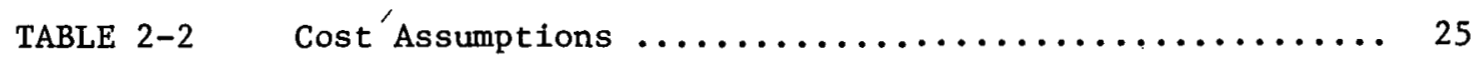

TABLE $2-3 \quad$ Fusion Capital Costs Learning Curves ............ 27

TABLE $3-1 \quad$ Summary of Scenarios $\ldots \ldots \ldots \ldots \ldots \ldots \ldots \ldots \ldots \ldots \ldots \ldots \ldots$

TABLE $3-2$ Total Cumulative Fossil Resource Use $\ldots \ldots \ldots \ldots \ldots \ldots$

TABLE $3-3$ Discounted Net Benefits $(\mathrm{HZ}) \ldots \ldots \ldots \ldots \ldots \ldots \ldots \ldots$

TABLE 3-4 Change in 1975 Discounted Present Value - Early

Implementation of Fusion $\ldots \ldots \ldots \ldots \ldots \ldots \ldots \ldots \ldots \ldots$

TABLE $4-1 \quad$ Electrification Trends $\ldots \ldots \ldots \ldots \ldots \ldots \ldots \ldots \ldots \ldots \ldots . \ldots \ldots$

TABLE $4-2 \quad$ Fuels Consumption Projections ................ 61

TABLE 4-3 Fuels Consumption Projections (this study) .........63

TABLE 4-4 Future U.S. and World Population and Energy Use ...... 67

TABLE B-1 Results for Different Discount Rates ............ 85

TABLE $C-1 \quad$ Base Case Data Set $\ldots \ldots \ldots \ldots \ldots \ldots \ldots \ldots \ldots \ldots \ldots \ldots \ldots \ldots \ldots \ldots \ldots \ldots$

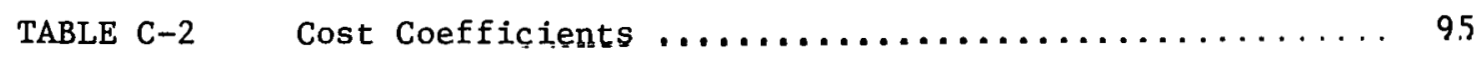

$\begin{array}{ll}\text { TABLE } & \text { Health } \& \text { Environmental Emissions and Efferts } \\ & \text { Coefficients } \ldots \ldots \ldots \ldots \ldots \ldots \ldots \ldots \ldots \ldots \ldots \ldots \ldots \ldots \ldots \ldots \ldots\end{array}$ 
FIGURE 2-1 Annual Resource Consumption $\ldots \ldots \ldots \ldots \ldots \ldots \ldots \ldots \ldots \ldots \ldots$

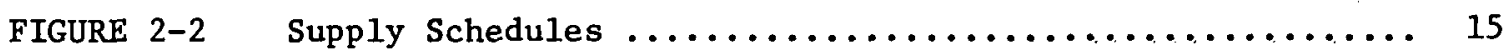

FIGURE 2-3 Reference Energy System, Year $1972 \ldots \ldots \ldots \ldots \ldots \ldots \ldots \ldots$

FIGURE 2-4 Reference Energy System (TPRESG), 1975 Data ........... 19

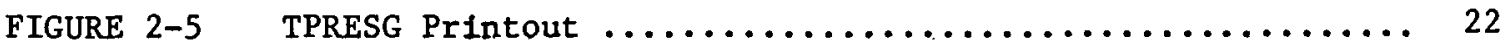

FIGURE $2-6$ Fusion Capital Cost Learning Curves $\ldots \ldots \ldots \ldots \ldots \ldots \ldots$

FIGURE 3-1 Annual System Cost \& Resource Use (HZ) $\ldots \ldots \ldots \ldots \ldots \ldots . . .$.

FIGURE 3-2 Annual System Cost \& Resource Use (HH) $\ldots \ldots \ldots \ldots \ldots \ldots \ldots$

FIGURE 3-3 Annual System Cost \& Resource Use (Drastic Limits) ..... 41

FIGURE $3-4$ Total Resource Consumption $\ldots \ldots \ldots \ldots \ldots \ldots \ldots \ldots \ldots \ldots$

FIGURE 3-5 Annual System Cost \& Resource Use (MZ) $\ldots \ldots \ldots \ldots \ldots \ldots \ldots 44$

FIGURE 3-6 Annual System Cost \& Resource Use (HH) ............ 45

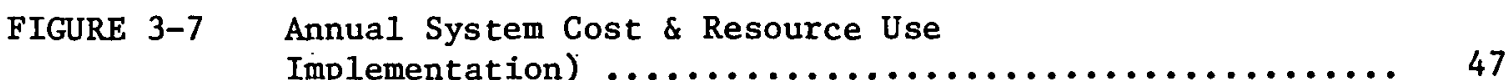

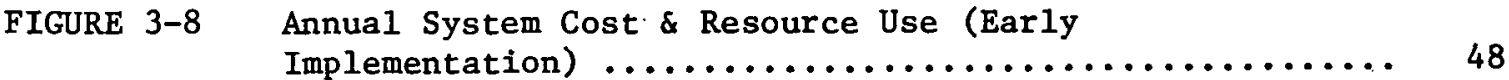

FIGURE 3-9 Effect on System Cost of Fixing Coal Supply Curve ..... 51

FIGURE 3-10 Effect of Capital Cost Learning Curves $\ldots \ldots \ldots \ldots \ldots \ldots$

FIGURE 4-1 Total Resource Consumption (to 2000) $\ldots \ldots \ldots \ldots \ldots \ldots \ldots$....... 58

FIGURE 4-2 U.S. Population - Projections to $2050 \ldots \ldots \ldots \ldots \ldots$

FIGURE $4-3$ Annual Resource Consumption .................... 69

FIGURE 5-1 Annual System Cost \& Resource Use - Total Consumption Comparisons .................................. 74

FIGURE B-1 Net Benefit Stream $\ldots \ldots \ldots \ldots \ldots \ldots \ldots \ldots \ldots \ldots \ldots \ldots \ldots \ldots$

FIGURE C-1 Reference Energy System (TPRESG), 1975 Data ......... 81 
FIGURE C-2 Reference Inergy System (TPRESG), Energy Flow Activity Variable Indexes $: \ldots \ldots \ldots \ldots \ldots \ldots \ldots \ldots \ldots \ldots \ldots \ldots . \ldots 9$

FIGURE C-3 Reference Years $\ldots \ldots \ldots \ldots \ldots \ldots \ldots \ldots \ldots \ldots \ldots \ldots \ldots \ldots$

FIGURE $C-4$ TPRESG Program Flow Chart $\ldots \ldots \ldots \ldots \ldots \ldots \ldots \ldots \ldots$

FIGURE C-5 Energy Activity Levels - National Annual Totals ...... 102

FIGURES D-1 Energy Activity Levels - National Annual Totals

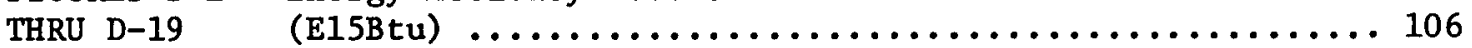




\section{ABSTRACT}

For fusion to become available for commercial use in the 21 st century, $R \& D$ must be undertaken now. But it is hard to justify these expenditures with a "cost/benefit" oriented assessment methodology, because of both the timeframe and the uncertainty of the future benefits. Focusing on the factors most relevant for current consideration of fusion's commercial prospects, i.e., consumption levels and the outcomes for fission, solar, and coal, many possible futures of the U.S. energy system are posited and analyzed under various assumptions about costs. The "Reference Energy System" approach was modified to establish both an appropriate degree of detall and explicit time dependence, and a computer code used to organize the relevant data and to perform calculations of system cost (annual and discounted present value), resource use, and residuals that are implied by the consumptions levels and technology mix in each scenario. Not unreasonable scenarios indicate benefits in the form of direct cost savings, which may well exceed $R \& D$ costs, which could be attributed to the implementation of fusion. 


\section{PREFACE}

This study was undertaken to examine how and what degree fusion might be expected to contribute to the future of the U.S. energy system. We live in a highly complex and uncertain world--a fact more pervasive and significant than is usually acknowledged in much modeling and assessment activity. To know what happened last year is hard enough. To know what will happen fifty or one-hundred years into the future is clearly impossible. The initial phase of our work was centered on establishing an approach and methodology: to develop a framework that would organize any quantification that might be undertaken, and to focus it on issues that could be meaningfully addressed.

The long time scale involved and its attendant high degree of uncertainty became the dominant consideration as each of several existing energy models were considered. Among others, these included the Brookhaven linear programming models BESOM and DESOM and the Institute for Energy Analysis (IEA) Energy Simulation Model. It was decided to develop an accounting model approach which would keep the highly explicit and aggregated features of the IEA work, while overcoming the artificiality of its supply-demand matching procedure. At the same time, economics was also incorporated, though not to the extent of the normative cost-optimization approach of the linear program models.

In earlier work, the static model BESOM had been used to study the impact of district heating applications on fusion implementation. The present study began as a follow-on to that effort, with the recognition that time dependence should be explicitly incorporated, and that a simpler model of the energy system would probably be appropriate.

The Reference Energy System description of energy flows provided an excellent point of departure for the development of an interactive computer program, 
a subtask whose successful completion relied totally on the quick and imaginative programing of Gary Goldstein and innumerable insights from Ellen Cherniavsky. The major variables relevant to fusion were quickly identified--total demand, and the extent and costs of alternative resources. To investigate each of these, the expertise of the National Center for Analysis of Energy Systems (NCAES) was relied upon heavily--Morris Beller, Chaim Braun, and Doug Gunwaldsen were most helpful in discussions about each of the major supply sectors and their respective possible implementation schedules.

At the urging of Ron Kostoff (ERDA), the concept of a "Cost/Benefit" analysis was introduced into the study, beginning with an examination of the state of the art to evaluate its applicability to fusion. If the study was to make a useful contribution in the area of $R \& D$ budget priority evaluation, it would have to consider commonly used parlance and concepts at least as a point of departure.

Suggestions from Ken Hoffman were helpful in examining issues of Cost/Benefit analysis. Very helpful and thorough critiques of an earlier draft were done by Dave Behling, Morris Beller, and Ron Kostoff.

Absolutely vital to the entire effort was Pam Walton's cheerful and prompt typing of the far too numerous revisions and additions, and Stan Majeski and Metzi Rappold's attention to the figures and drawings. 
This study was undertaken to explore the potential role fusion might play in the future U.S. energy system, especia11y as interpreted through a Cost/ Benefit Analysis, and as it might bear on current $\mathrm{R} \& \mathrm{D}$ decisions. Purposes of the Study

- To determine the conditions under which fusion could contribute significantly to long range U.S. energy needs, and

- To apply Cost/Benefit Analysis so as to examine its suitability, 1imitations, and relevance to the case of fusion.

\section{Approach}

To evaluate the potential role of fusion by:

- Developing a perspective on the issues that can be meaningfully addressed,

- Developing a methodological framework which sufficiently and appropriately characterizes the U.S. energy system,

- Identifying the key factors that will bear on the need for fusion,

- Identifying which quantitative assumptions about the future of energy result in a finding that benefits are indeed attrihutahle to fusion, and

- Making explicit the consequences imbedded in those assumptions.

\section{Conclusions}

- This study demonstrates the extreme sensitivity of Cost/Benefit Analysis to input assumptions which, because of the time scale of fusion, must be highly arbitrary. The applicability of Cost/Benefit to fusion is therefore questionable.

- Nevertheless, not unreasonable scenario comparisons, with and without fusion, indicate benefits in the form of direct cost savings which could substantially exceed the projected costs of $R$ \& $D$ (depending on the choice 
of discount rate); this without an accounting of externalities--the benefits of avoiding pollution and nuclear proliferation, as well as the benefit of the availability of energy itself.

- Simple arithmetic and common sense provide powerful constraints on allowable or reasonable projections of future total energy use and combinations of energy supply. However, the parameter space of possible energy futures remains large.

- By mapping out parts of that space, some of the factors critical to the need for fusion have been explored:

1. the future behavior of total energy consumption, and

2. the future availability and cost of alternative supplies.

- In certain regions of that space, significant benefits are attributable to fusion.

The potential benefits of a commercial fusion program are enhanced in a world where: 1) total demand continues to grow, and/or 2) where alternative resources are limited or costly:

- If imports are restricted,

- If coal use cannot increase greatly (because of limitations on production capacity, increasing costs, or environmental effects),

- If fission is not to be greatly expanded and developed in a form which can make more complete use of the resource,

- If central station solar cannot be made reliable and economic,

- If the choice of discount rate is not too high, and

- If fusion can be available earlier and quickly implemented, regardless of initial cost. 
An extreme in any of these factors, or any combination of them to a lesser degree indicates the necessity and desirability of substantial reliance on fusion energy in the twenty-first century.

Particulars of the Study

Projections were developed for each of the major supply sectors over the next 100 years, incorporating assumptions regarding possible technical and policy developments for each resource. Levels of total energy consumption were fixed by assumption, distinguishing two cases in the near-term (HIGH and LOW) based on detailed demand analysis, and two cases in the long-term (HIGH and ZEG) based on possible trends. The zero growth cases level off at 115 and 180 Quad respectively, with the high cases reaching 240 to 300 Quad by the year 2075 . Scenarios were developed for each total consumption case using various combinations of the different supply projections.

The "Reference Energy System" concept was modified to incorporate a greater degree of aggregation and explicit time dependence, and a computer code was developed to organize the relevant data, to permit interactive user modification of scenarios, and to perform calculations of system costs, resource depletion, and envirunmental effects. Total annual system cost was calculated in each of the 100 years, based on cost figures which were estimated for the various fuels and capital equipment. Calculations were also done of the cumulative discounted present value using different discount rates and starting dates.

Basic trade-offs among resources were studied, and some sensitivity analyses were done on coal cost, fusion introduction date, and fusion capital cost:

- Fusion is absolutely required to meet even modest energy demand, in cases involving less optimistic assumptions about alternatives. 
- Very high initial fusion plant capital costs can be tolerated on a system-wide basis, with widescale implementation of fusion to follow only as the ensuing learning curve brings the capital costs down.

- Early introduction of fusion considerably enhances its cost/benefit picture.

The cases which indicate the greatest relative benefits of fusion (i.e., the difference between the total system cost of two scenarios with and without fusion) are those involving high reliance on coal and high costs for coal. In these cases the use of fusion to replace a major portion of the coal use results in systems savings which can reach a level of $\$ 200$ to 500 billion/year out of total annual cost of $\$ 700$ to 1100 billion/year. For assumptions leading to lower relative benefits, it must be remembered that only direct costs have been considered. Decisions are more likely to be made on the basis of the less quantifiable externality issues such as health, safety, and the environment. For example, society may make a political (noneconomic) desision against plutonium, or a health decision against expanded coal usage.

Future work should focus on developing alternative methodologies to deal with the question of present society's responsibility for future generations, and help in the decisions which allocate current $\mathrm{RD} \& \mathrm{D}$ expenditures. For example, the range of energy, supply, demand, and cost projections might be handled with a probabilistic approach, as an advance over the use of deterministic single-valued scenarios whose relative likelihood of occurrence can only be implicitly considered. Uncertainty is a key issue--it is one of the reasons discounting is used, and at the same time the reason why a more complex treatment is needed. Keeping energy options open involves the expenditure of resources and the bearing of risk, where the possibility of failure must be weighed against the possibility of immense value if not critical necessity. 


\section{Chapter 1}

\section{INTRODUCTION}

\section{A. Background and Purposes}

Fusion energy is released when certain light atomic nuclei undergo nuclear reactions to form heavier elements. For such reactions to occur, extraordinary conditions of temperature and pressure are required, which so far have occured only in stars and in thermonuclear devices (the hydrogen bomb). The goal of the fusion $R \& D$ program is to create such conditions in a reactor, suitable for the generation of useful energy. The relevant physics and engineering for such devices have been widely examined. ${ }^{1,2}$ This study, however, examines the role fusion might play in the U.S. energy system from the standpoint of economics, environment, and resources. ${ }^{3}$

Fusion $R \& D$ is public business because the uncertainty of success, the time scale, and the financial requirements of fusion development prevent the private sector from undertaking it fully. Thus, fusion will require public funding and significant physical and social resources for its development. For these expenditures to be justified over the claims of all the many competing 
and urgent problems and programs, fusion must hold some promise of meeting the demonstrable future needs or desires of society in a technically and economically practical manner. Also, our society has begun to learn to evaluate what use will be made of any new technology, and fusion is no exception.

The questions underlying this work are these: On what basis can fusion $\mathrm{R} \& \mathrm{D}$ be justified? Will fusion be needed, or be able to make an important contribution to future energy needs? Will its benefits, in the usual terminology, outweigh its costs?

\section{B. Approach}

The central question addressed in this study is somewhat narrower: to identify and analyze the quantitative assumptions about the future of society and energy which relate to judgments about the necessity or desirability of fusion. A corollary concern is the justification of current $R \& D$ spending on a Cost/Benefit or other basis, acknowledging the many difficult methodological and philosophical issues involved. With respect to the former, a scenario approach is used to describe alternative futures of the U.S. energy system. For the latter, a dual approach is taken. First, a straightforward Cost/Benefit analysis is performed, but partially reversed from normal procedure. Second, the relevance and applicability of Cost/Benefit Analysis are examined, especially with regard to the long time-scale of fusion. (See Appendix. A.) Some modest suggestions are offered about where its relevance might be strengthened and in what directions alternative methodologies might be sought.

The "reversal" of normal Cost/Benefit procedure ${ }^{4}$ involves asking first how big the net benefits of fusion in the twenty-first century would have to be 
in order to justify current $R \& D$ budgets on a discounted present value basis (depending of course on the choice of discount rate). The normal tendency is to presume that for long time scales, discounting totally obliterates the effect of any future net benefits, so that only immense benefits would result in a non-negligible present value. Interestingly, simple calculations indicate that the required quantities are not so outrageously large when compared with potential cost differences among various scenarios for the U.S. energy system. (The benefits of fusion are taken as the system cost savings brought about by its implementation.) These results are discussed in Chapter 2, and the calculations described in Appendix B. The relevance of Cost/Benefit Analysis and discounting to long-range projects is controversial--some of the arguments often put forth are summarized in Appendix A. It is nevertheless useful to proceed with a Cost/Benefit Analysis because it does provide insights, because alternative methodologies are not widely available or accepted, and finally because various agencies of government insist upon it as a standard means of program evaluation.

\section{Methodology}

The quantitative descriptions of alternative energy futures were developed using a simplified model of the entire U.S. energy system over the next one hundred years. The major factors which will bear most directly on the need for fusion were identified and examined. Levels of total energy consumption in the U.S. were established, distinguishing two cases in the near-term (HI and LOW) based on detailed demand analysis, and two cases in the long term (HI and ZEG) based on possible trends. Independently, projections were developed to provide several difterent possible implementation schedules for each of the major supply sectors, incorporating assumptions regarding many possible 
technical and policy developments for each resource. Clearly the extent to which fusion will be implemented will depend on total energy demand and on the availability and cost of alternative sources: oil and gas, coal, fission, solar, and of course fusion itself.

Complete scenarios were constructed by selecting from among the various supply schedules to meet each of the demand projections, within a model of the U.S. energy system which was adapted from the "Reference Energy System" concept. 5 A computer code was developed to organize the relevant data to permit interactive user modification of scenarios and to peiform calculations of system cost, resource depletion, and environmental effects. Total annual system cost was calculated in each of the 100 years, based on cost figures which were estimated for the various fuels and capital equipment. The actual behavior over time of the system cost stream offers more detailed information and insight into implications of different energy futures than is provided under discounting. However, the cumulative discounted present value was also calculated using several diffèrent discount rates and starting dates. The intent of developing the model was to provide a convenient means to make explicit the consequences of a given set of assumptions about the future of the energy system. The approach first requires that the scenario ("fuel m1x") be self-consistent and reasonable in each of the one-hundred years--totals must add up properly and supply must equal demand, with all conversion effi_...... ciencies taken properly into account. Furthermore, each variable must exhibit smooth and reasonable behavior over time. Only then can an assessment be undertaken of the economic, resource, and environmental effects implied by the consumption level and technology mix of a given scenario. 
The development of the approach and.methodology (the "right tool for the job") constituted a major subtask in itself and is discussed in Chapter 2. Results and analyses of several scenarios are presented in Chapter 3 . In addition to the basic question of the potential discounted benefits of fusion, several other issues are explored, such as drastic limits on alternatives, and acce1erated development of fusion (early implementation). Chapter 4 offers the philosophical and methodological basis by which the total consumption scenarios were derived. This most basic variable requires different treatments for the near and far-terms. Cost/Benefit Analysis is discussed in Appendix $A$, where some of its controversial aspects are reviewed. The reader is encouraged to establish his own view of the suitability of cost/benefit to fusion as the application of it undertaken here unfolds.

Several caveats should be noted. First, no attempt is made here at prediction. Rather the study examines future possibilities. Second, no claim is made that the pertinent parameter space has even begun to be explored. The number and variability of outcomes for the U.S. and the world increases greatly as one considers a longer time scale, but only a very few can receive detailed scrutiny. This study has aimed at a useful bracketing of possible ranges of some of the relevant variables.

No attempt is made here to assess the desirability of relative "benefits" of a greater or lesser amount of energy consumption. Nor is any assertion been made as to whether or to what extent GNP growth, or the more relevant but less quantifiable "quality-of-life", will depend on energy in the long run. The discussion of benefits in terms of direct energy system cost savings has the advantage that it can readily be done, although such savings may not, in the final analysis, be the most important consideration in determining the extent of fusion implementation. 
1. D. Steiner, The Technology Requirements for Power by Fusion, Nuvl. Science and Engineering, 58 107-156 (1975).

2. R. F. Post and F. L. Ribe, Fusion Reactors as Future Energy Sources, Science 186, 397, (November, 1974).

3. G. L. Kulcinski, Fusion Power - An Assessment of its Potential Impact in the USA, Energy Policy, P. 104 (June 1974).

4. Ideally a Cost/Benefit assessment would proceed first from an ingenuous and thorough enumeration of all costs and benefits to a later determination of the Cost/Benefit ratio. With so much latitude in the determination of the costs and benefits in the case of fusion, however, such a procedure could not meaningfully be undertaken.

5. Sourcebook for Energy Assessment, M. Beller, ed. BNL Report No. 50483 (December 1975). 


\section{Chapter 2}

\section{APPROACH AND METHODOLOGY}

\section{A. Introduction}

Developing the approach and methodology was in one sense a separate subtask from the analysis and generation of results and conclusions. But there was also give and take between these interdependent means and ends, as both became more clearly defined over the course of the study.

With the general initial objective in mind (see Chapter 1) the first task was to identify the major variables or key factors considered to have the greatest bearing on the potential need for fusion. There then followed the parallel tasks of determining what level of detail was appropriate and choosing a suitable model. Then total energy demand projections were developed together with projections of possible implementation schedules for each of the major supply resources. Scenarios of the energy future of the U.S. were then constructed by selecting various combinations of the different supply 
options to meet each of the total demand projections. Total energy system cost was calculated using cost estimates for the several fuels and technologies that were distinguished in the model.

The "benefit" of fusion was taken as the difference in annual system cost for two otherwise comparable scenarios with and without fusion. The first step of the "reversed" cost-benefit approach, however, was the ca1culation of miminum long range net benefits.

B. Long Range Benetits

A straight forward calculation was done to determine the minimum long range net benefits that result in a $\$ 10$ billion dollar present value as of 1975. This calculation is presented in detail in Appendix $B$. The $\$ 10$ billion figure represents an approximation of the present value of the projected Fusion $R \& D$ program cost (expected to total $\$ 20$ billion to be spent between now and the year 2000). This is the "cost" to be matched or exceeded by the "benefit" referred to above, if the fusion $R \& D$ program is to be justified on this basis.

A net benefit stream was assumed to start in the year 2025 , increasing linearly through the year 2075. This "wedge" of savings approximates the general shape of an actual net benefit stream that might result from the difference in system cost between two different scenarios. Table 2-1 shows the annual savings the wedge must reach by 2075 , to give the cumulative discounted present value in 1975 of $\$ 10$ billion. The total net benefit, or area of the savings wedge, is given in the last column. The extreme sensitivity to discount rate is noteworthy. Going from a $5 \%$ to a $10 \%$ discount rate increases the required annual benefit in 2075 by over a factor of 50 .

Also perhaps surprising, and contrary to the usual supposition, is the fact that these figures for the annual benefit are not astronomical (for some discount rates), but as is demonstrated later are in some cases quite within the range of possible 
TABLE 2-1

PRESENT VALUE OF FUTURE BENEFITS

\begin{tabular}{|c|c|c|c|c|}
\hline \multirow{4}{*}{$\begin{array}{l}\text { DISCOUNT } \\
\text { RATE }(\%)\end{array}$} & \multicolumn{4}{|c|}{ BILLIONS OF DOLLARS } \\
\hline & \multicolumn{2}{|c|}{ PRESENT VALUE } & \multirow{3}{*}{$\begin{array}{l}\text { ANN. NET } \\
\text { BENEFIT } \\
\$ / \mathrm{yr} .2075 \\
\end{array}$} & \multirow{3}{*}{$\begin{array}{l}\text { TOT.NET } \\
\text { BENEFIT }\end{array}$} \\
\hline & & & & \\
\hline & $\underline{1975}$ & 2025 & & \\
\hline 0 & & 10 & 0.4 & 10 \\
\hline 1 & & 16.4 & 0.9 & 23 \\
\hline 3 & & 43.6 & 4.4 & 110 \\
\hline 5 & 10 & 118 & 20 & 500 \\
\hline 7 & & 307 & 83 & 2,080 \\
\hline 9 & & 825 & 330 & 8,250 \\
\hline 10 & & 1,155 & 550 & 13,800 \\
\hline 15 & & 11,220 & 11,000 & 280,000 \\
\hline
\end{tabular}


system cost savings. In any event, the required "benefit" is estimated, whether such amounts are to be found in cost savings, or in estimates of the many less commensurable advantages that might be attributed to the use of fusion. ${ }^{2}$

C. Time-Scale and Uncertainty

The study approach was in large part dictated by the long time scale involved--a context dominated by uncertainty. Highly detailed characterizations or models of the energy system (technological, economic, and soctal) were not attempted, as they could not be provided with adequate or meaningful input data for the time-scale under consideration. Furthermore, a broader based description more readily permits the kinds of issues that are of interest to be addressed: these concern the gross features, and not the details, of the overall future of energy over the next 100 years. To that end, the entire U.S. energy system ${ }^{3}$ from resource supply through conversion to end use was described in terms of five supply and three end use categories with conversion processes and energy flows which connect them specified at a commensurate level of detail. Using this framework, a completed scenario consists of an entire set of energy activity levels specified for each of the 100 years from 1975 to 2075, thus representing one possible future state of the U.S. energy system that might arise from technological developments, resource availability or policy action. For the exploration of economic implications, an optimization or economic (price) deterministic approach was not undertaken, again because of the time scale and uncertainty. ${ }^{4}$ Instead of allowing cost estimates to determine the levels of implementation of the various technologies, the methodology used here first assumes implementation levels exogenously in the form of working hypotheses, and then explores their economic and other implications in a straightforward manner. Environmental effects are calculated from 
coefficients input separately, and each scenario is evaluated under several different sets of cost assumptions embodying different possible futures of energy costs. 5

\section{Major Areas of Uncertainty}

Whether or not fusion will be needed, and if so to what extent, will depend on several major factors, which can be roughly categorized under supply and demand. A discussion of demand, or consumption, ${ }^{6}$ would include matters such as the rates and nature of the social and technical change which establish our energy needs; the changes in consumption patterns and efficiencies, as affected by environmental concerns, cultural values, technological developments, and the availability of supplies. What will the long-range pattern of energy consumption be? Are there "Limits to Growth?" Under the heading of supply comes a description of the several major resource and supply technology options--the availability, viability, costs, and externalities of coal, oil and gas, fission (including the breeder), renewable (solar), and fusion.

These are the basic and interdependent major variables (here presented as separable issues only to facilitate analysis) that will bear on the future need for fusion. Each is discussed in turn, both as to its general aspects, and to the approach taken to incorporate these aspects into the analysis.

TOTAL ENERGY RESOURCE CONSUMPTION

Twentieth century energy demand levels have been set according to projections in the current literature, where extrapolations of detailed historical and present trends have been performed. Detailed extrapolation would not be suitable to the far term (after 2000). Instead, general possible trends were used to define overall energy consumption levels. 


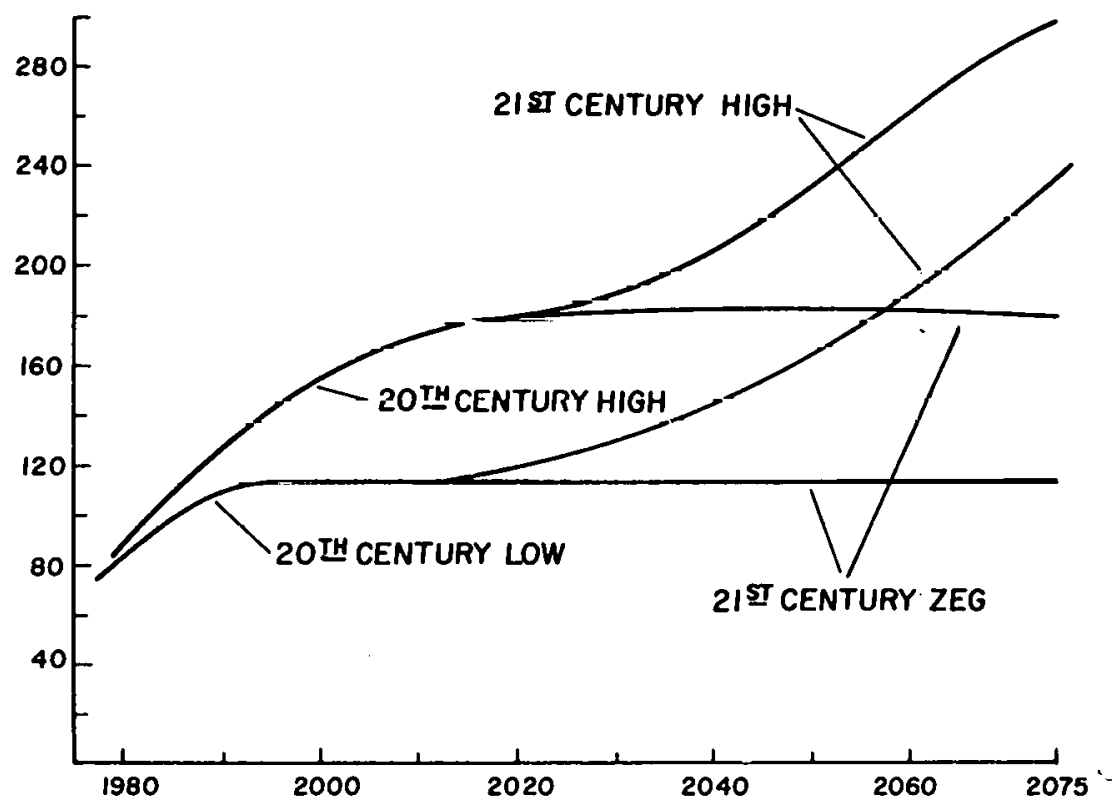

Figure 2-1. Annual resource consumption $10^{13} \mathrm{~B} t u /$ Year. 
The near-term (20th century) was thus separated from the far-term (21st century) because the methodology appropriate to each one is different. Even with the more exacting approach that can be applied to the 20th century, by the year 2000 the range of variation among different projections is substantial; and two cases were chosen to represent that range. For the 21st century, it was assumed that consumption would level off, and only the advent of some advanced technology would permit renewed growth. Four scenarios were defined for the total annual resource consumption over the 100 year period of the study, as shown in Figure 2-1. The more detailed scenarios which define the complete fuel mix comprising these total demands are labeled LZ, HZ, LH, and HH; referring to Low or High, and Zero Growth or High, in the 20th and 21st centuries respectively. A detailed discussion of these matters appears in Chapter 4. SUPPLIES

The many factors involved in each of the various supply resources are increasingly discussed in every conceivable forum, from the popular press to academia, government, and the general population. Yet another recitation of these issues is therefore not included here. Instead, two or more scenarios are posited for each major supply category to represent the fundamentally different possible outcomes for each, with quantities and growth rates adapted from the various studies which provided the near-term total consumption projections discussed in Chapter 4.

0i1 and Gas, the major fuels today, are eminently exhaustable, even globally, and will not be major long-term sources of energy. For the study, they were combined into a single category, including all domestic and imported resources. Two possibilities are considered. In the first, oil and gas continue to play a major role in the near and aid terms with consumption at about the current 
level, implying continued increasing reliance on imports and vigorous secondary recovery in domestic production. A second scenario involves no imports, but domestic production continues even after 2050 (possibly optimistic). See Figure 2-2a.

LWR's and breeders were aggregated to form a single fission category. Two scenarios are assumed. In the first, wlthout the breeder, fission generation is limited in time (because of uranium resource limitations) and falls off after peaking some time after the year 2000. In the second, fission continues to make a steady state contribution through the use of breeders. However, it is assumed that the difficulties associated with the breeder will limit its acceptability to some degree, constraining its implementation. At issue is whether the public will accept the plutonium economy or not (See Figure 2-2b). A third scenario involves intensive breeder implementation, even though this is considered to be a relatively improbable outcome. Fission, on the threshold of true commercial maturity, is confronted with a now familiar host of problems which involve not its technical feasibility but its social acceptability.

Coal is often cited as the mainstay energy resource of the U.S., but there are considerable problems to be expected from a vastly greater level of use, whether through direct combustion or by conversion to synthetic fuels. The severe environmental impacts involved in every part of the coal fuel cycle will not be readily or cheaply dealt with. In several scenarios, the use of coal was allowed to increase to whatever degree necessary to make up the slack between other resources, and the total resource consumption indicated for the scenarios. In some cases, this resulted in manifestly immense utilization of coal, the total U.S. proven reserves being exhausted within the next century, with annual production levels more than ten times current ones. In other cases, the use of coal was allowed to grow no higher than 50 Quad/yr. (roughly four times the current level), representing 

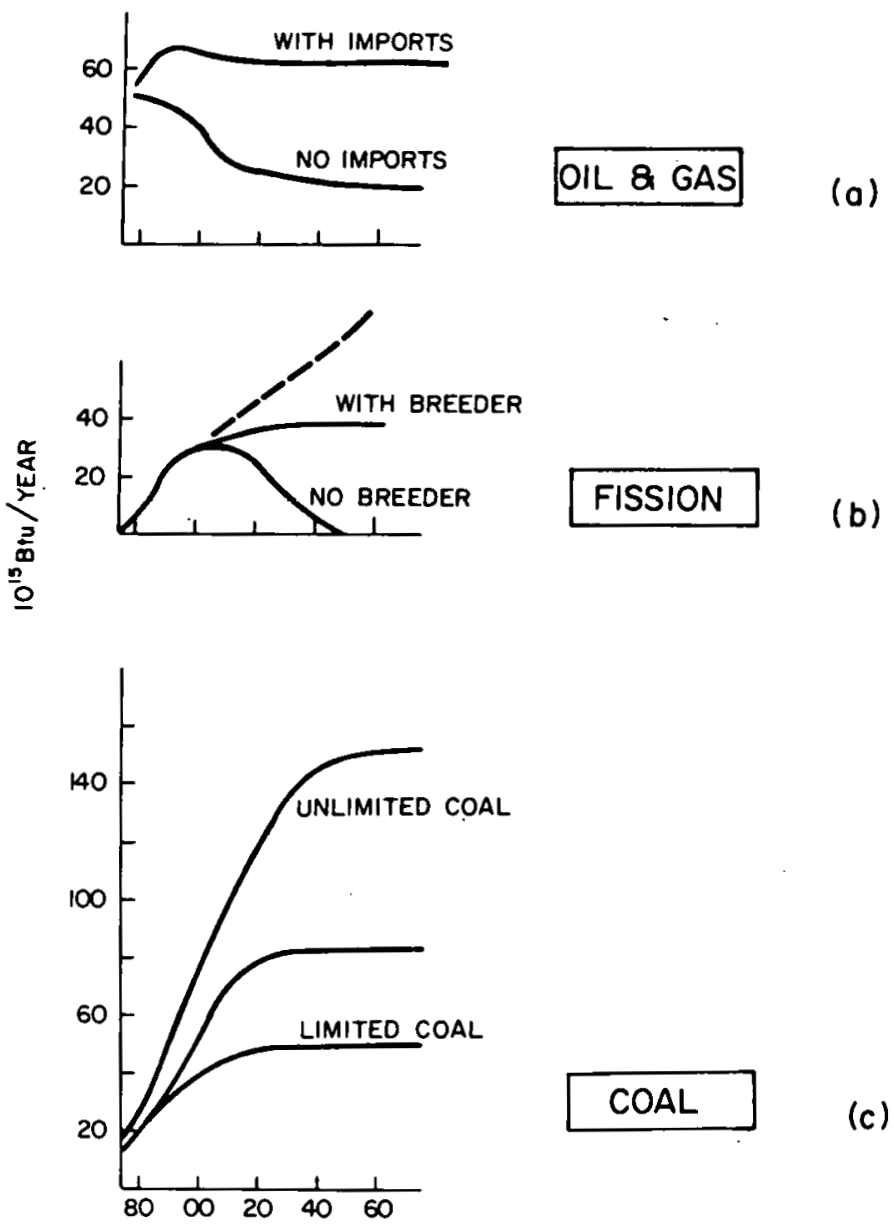

Figure 2-2. Supply schedules. 
the situation where either production capability or environmental damage results in such a limitation (see Figure 2-2c).

Fusion is assumed to contribute to national energy needs in the early part of the 21 st century, and its growth rate varies from high to very high in order to meet the postulated total energy demand. Fusion, implementated only if breeders are not, is assumed to relieve the pressure on other resources In the 21st century ZEG cases, and to be solely responsible for allowing later growth in the 21 st century HIGH cases. Like the other technologies, the fusion power reactor is treated here as a black box, characterized by a few parameters such as cost, efficiency, and environmental emissions. The probability of success of the $R \& D$ program and the question of what type of fusion reactor will be developed is not addressed here. Scenarios are simply run with or without fusion.

Solar Energy is separated into two distinct categories. Near-term technology solar thermal application to space conditioning is incorporated into the long-range total demand figures. It simply reduces the total demand for fuels and electricity. On the other hand, advanced solar electric (photovoltaic or thermal), like fusion, is an advanced technology which may or may not be available in the future for electrical power generation, and 18 characterized by 1 ts cost and environmental effects. RATE CONSTRAINTS

For each of these resources, the rate of change of implementation levels are constrained by several factors which were taken into account in establishing these scenarios. These include:

- Orderly retirement of existing capital equipment. A widely implemented technology with a large investment is not likely to be dropped suddenly. Typical plant life is 30 years, so rates of decline (or replacement) must reflect full utilization of equipment in place. 
- Maximum growth rate. ${ }^{7}$ During the early phase of the introduction of a new technology, very high rates (but small absolute numbers) of growth can be maintained. But as the number of plants increase, a lower percentage growth rate is to be expected.

- U1timate limits. It taxes one's imagination to foresee a full scale power plant on every street corner, or a construction rate corresponding to several new plants per week. Some cognizance must be taken of the realistic scale of things.

\section{E. The Model and Scenarios}

The description of the U.S. energy system used in this study specifies supply and demand categories together with the flows connecting them. It is based on the "Reference Energy System" technique ${ }^{9}$ which was devised at BNL. Figure 2-3 shows the RES diagram for the year 1972. Energy resources flow from left to right, undergoing conversion processes to reach demands. Energy quantities are given in Quads ( 1 Quad $=10^{15}$ BTU) and are national annual totals.

Figure 2-4 shows the simpler more aggregated version of the RES developed for this study to provide the framework to address the overall features of the energy system. The parameters of this simplified version are aggregated to reflect the major variables defined above, and to permit time dependence to be expl1c1rly and readlly Lrealed.

A computer program Time-Phased Reference Energy System Generator (TPRESG) was developed to organize the relevant data, to permit interactive user modification of scenarios, and to perform calculations of the system cost, resource depletion (cumulative and annual), and environmental effects which result from the consumption levels and the technology mix of a given scenario. 


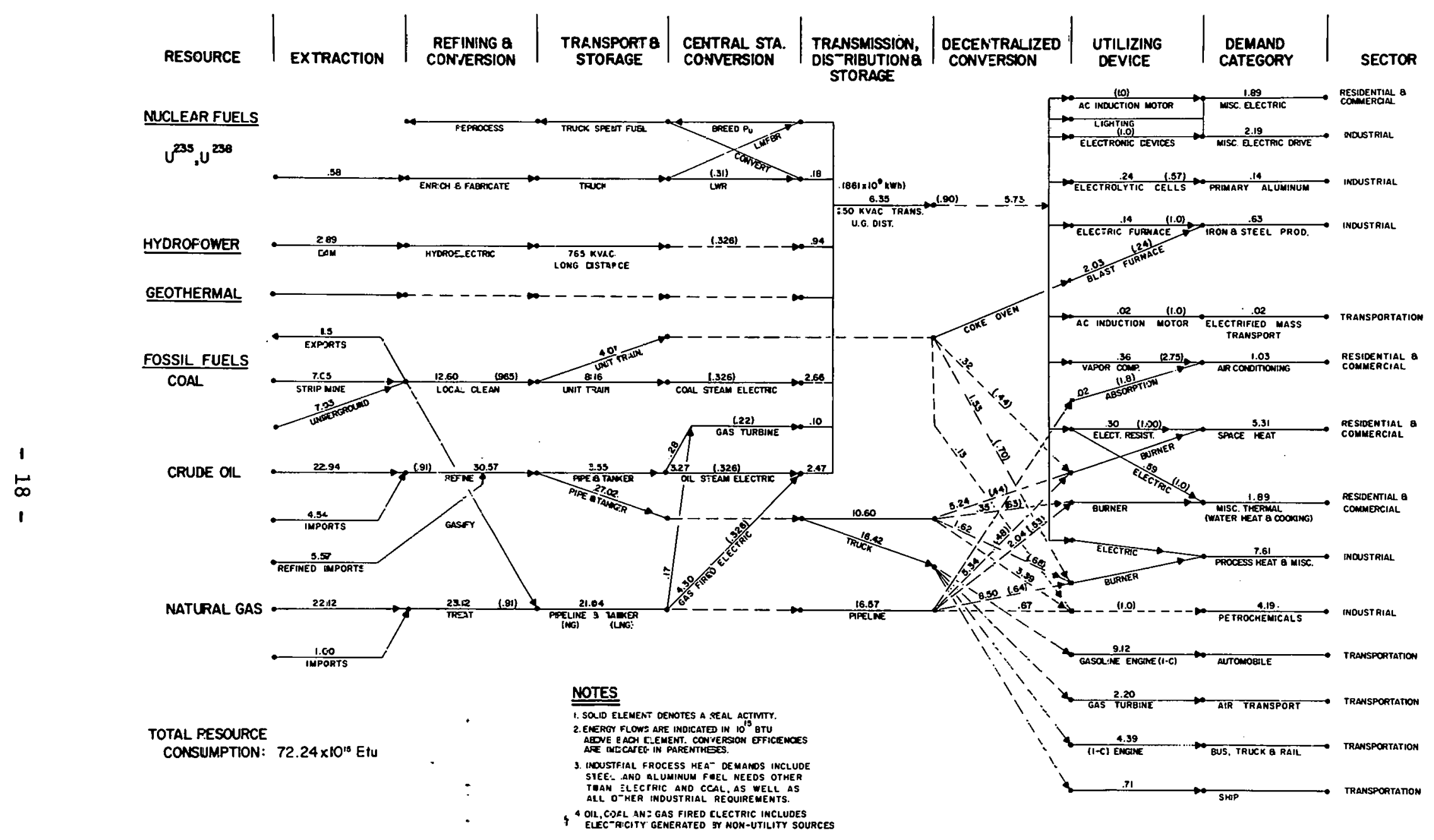

Figure 2-3. Reference energy system, year 1972. 


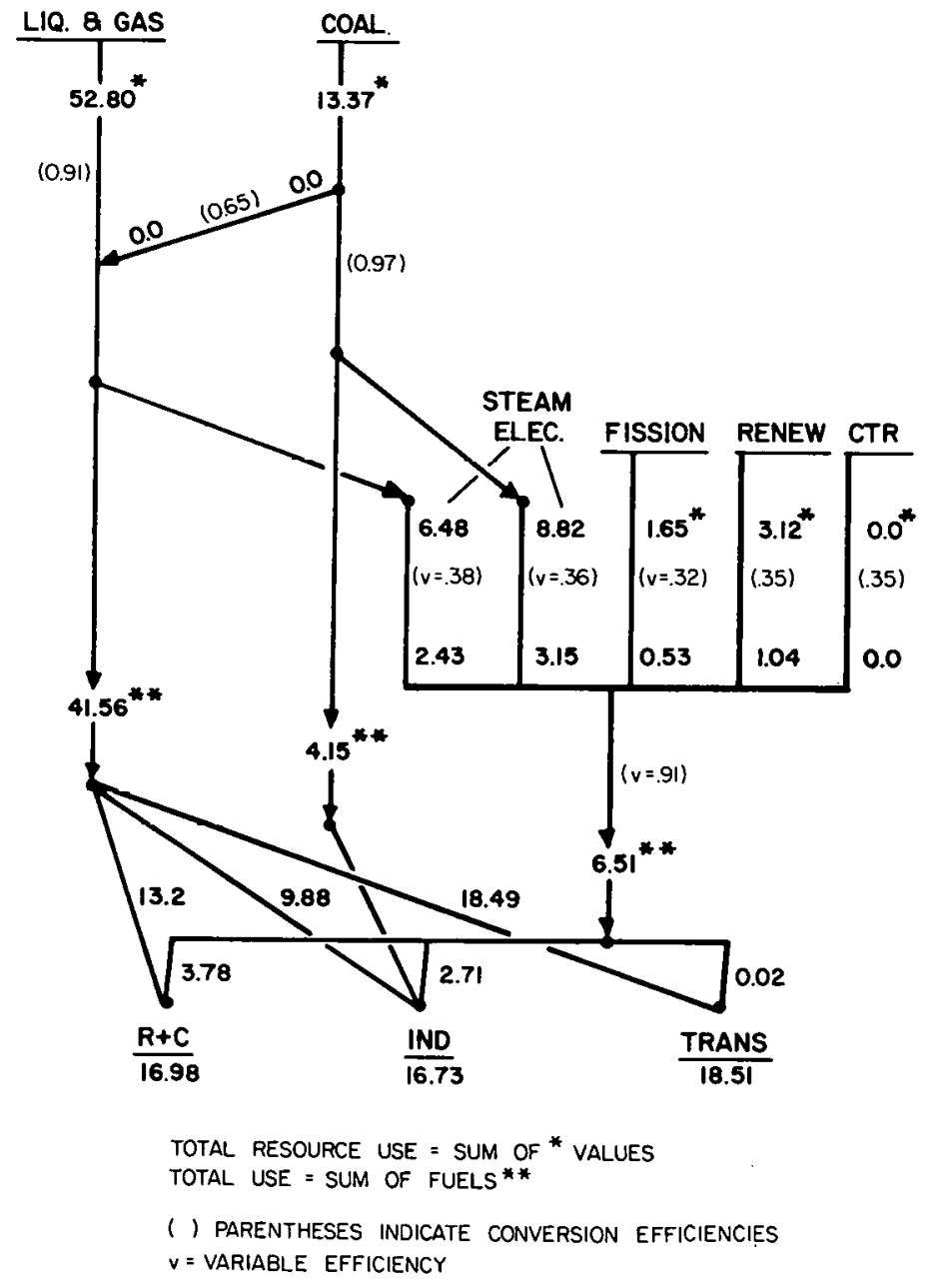

Figure 2-4.. Reference energy system T P R E S G (1975 data). 
Where the RES treats only one year at a time, in TPRESG each category activity level is exogenously specified over the entire 100 year time period. As the user makes changes to selected activities, the program corrects the value of associated parameters. For example, if coal-steam electric is changed, then corrected values are inserted for coal resource and total electricity, etc. With the time dependence of each variable explicitly displayed, the user can manipulate the scenario until each parameter exhibits smooth and reasonable behavior over time, while maintaining self-consistency at each point in time (1.e., the varlables in the RES are all properly arrayed). The final output is a complete set of energy activity levels and their resulting implications for each of the 100 years from 1975 to 2075, and thus can represent any given future course of the U.S. energy system which might arise from technological developments, resource availability, or policy action.

\section{SCENARIOS}

The approach taken to establish these complete scenarios involved first choosing a total consumption case, and then selecting from among the individual supply schedules to provide that total amount of energy. Judgment was exercised to limit the rapid escalation in the number of combinations that could result from even the limited number of choices available. ${ }^{8}$ In many cases coal was allowed to take up the slack between other supplies and total consumption. Through the year 2000, the individual supply schedules and technology mix follow closely the more detailed fuel mix described in the Sourcebook "reference" and "future" cases. 9 
SAMPLE TPRESG OUTPUT

Figure 2-5 shows the TPRESG printout for the "HIGH-ZEG" base case. Each group of numbers gives the levels of energy activities for reference years covering the 100-year period. These activities correspond exactly to those shown in the Reference Energy System (Figure 2-4). This output provides various characterizations of the energy system as calculated from the exogenously determined energy activity levels:

- Average annual percentage growth rates for selected activities are shown for the time intervals between reference years. Requiring smooth behavior over time is in effect a second derivative check on the time behavior of the activity. Note, for example, that fission experiences very high growth rates in the near term $(23.4 \%$ over the next five years).

- The Electrification Ratio is calculated as delivered electricity divided by the sum of all delivered fuels and electricity, making immediately evident any fuel mix assumptions which would imply drastic changes in end-use technology.

- Total Use and Total Resource are the total delivered fuels at the point of end use, and the total annual resource requirement, respectively. The difference between them is simply due to losses in conversion from resource to.usable fuel or electricity.

- Cost implications:

Total annual system cost is given. This includes operating and maintenance, annualized capital cost. (assuming a 30-year plant life and appropriate plant factors), and fuel and transportation costs: Enduse equipment costs were-not included. 


\section{rOSSII RESNURCES}

\begin{tabular}{|c|}
\hline 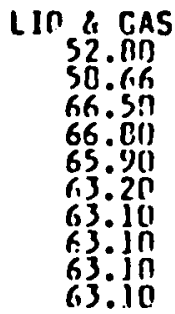 \\
\hline
\end{tabular}

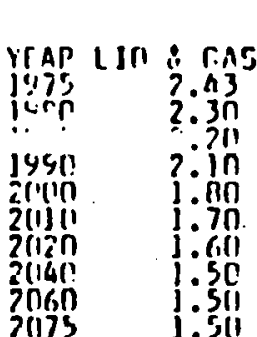

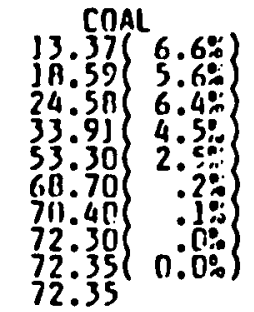

CLCCIAIC RENCAAIION

RE SnÜRE UGE (THERTML)

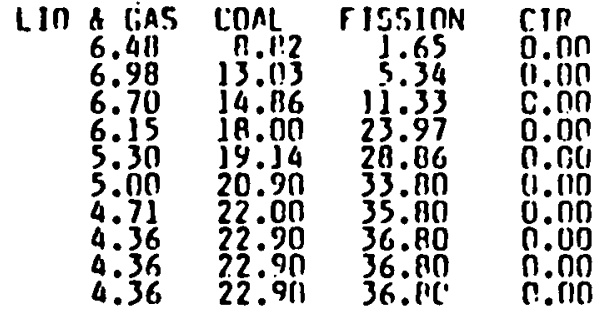

\section{TLTCTRICAL REREERATION}

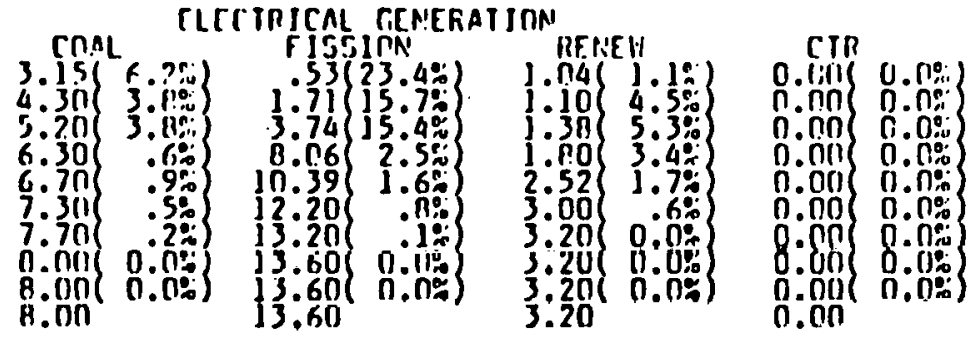

COAL IO SYNFUELS

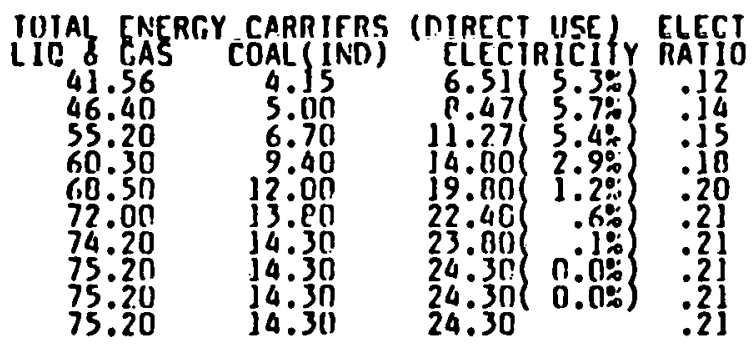

FINAL CONSIMPTION F.NO USE

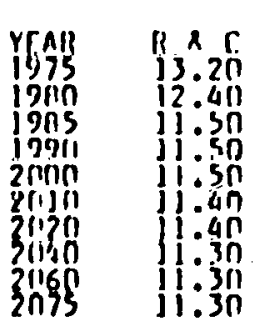

\begin{tabular}{|c|}
\hline 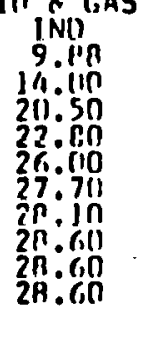 \\
\hline
\end{tabular}
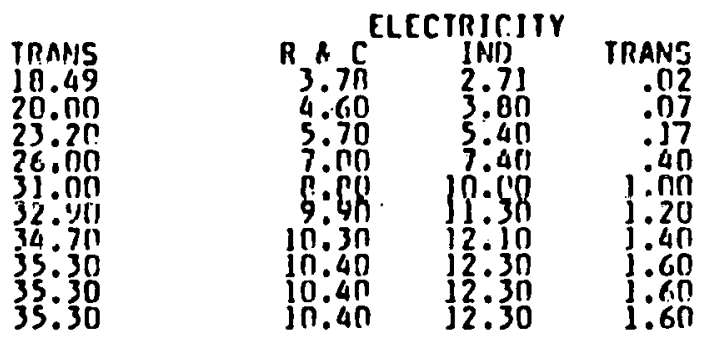

IIITALS

\begin{tabular}{|c|c|c|c|c|c|}
\hline 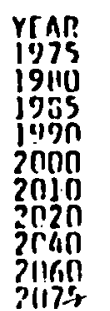 & 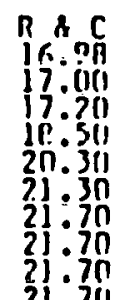 & $\begin{array}{l}140 \\
16.73 \\
22.8111 \\
32.110 \\
39.00 \\
48.0110 \\
52.001 \\
54.50 \\
55.20 \\
55.20 \\
55.20\end{array}$ & $\begin{array}{l}\text { 1RANS } \\
30: 51 \\
20: 17 \\
23: 37 \\
26: 40 \\
32.01 \\
31: 10 \\
36: 100 \\
36: 901 \\
36.90 \\
36.90\end{array}$ & 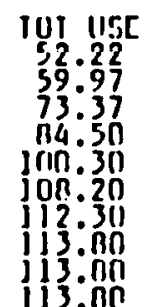 & 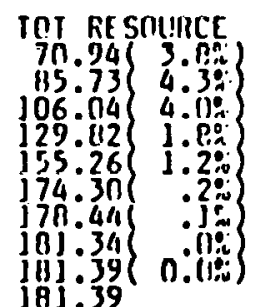 \\
\hline
\end{tabular}

Figure 2-5. Energy activity levels national annual totals (E15 BTU). 
IIITAL ARINIIAI SYSICH COST (T.9 DOLLAR.S)

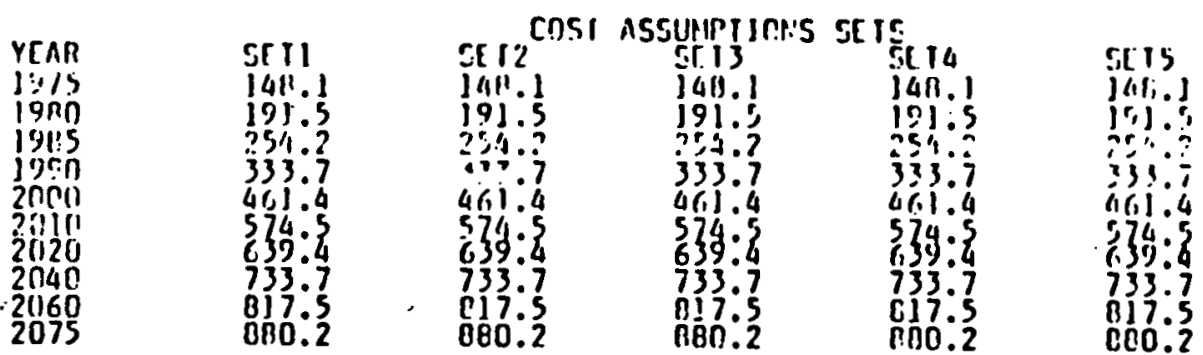

TO

DISCOUNIEO PRESENT VALUE OO CIMM. SYSTEH COST

\begin{tabular}{|c|c|c|c|}
\hline $\begin{array}{r}61238.2 \\
7433.0 \\
2860.6 \\
1691.3\end{array}$ & $\begin{array}{r}61238.2 \\
7483.0 \\
2860.6 \\
1691.3\end{array}$ & $\begin{array}{r}6] 238.2 \\
7483.00 \\
3068.6 \\
169 j .3\end{array}$ & $\begin{array}{r}61230.2 \\
7483.0 \\
2068.6 \\
1691.3\end{array}$ \\
\hline
\end{tabular}

\section{Tn 1995

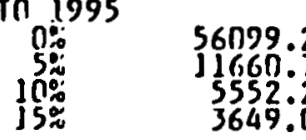 \\ $\begin{array}{rrrrr}6099.2 & 56099.2 & 56099.2 & 56099.2 & 56099.2 \\ 16600.7 & 11660.7 & 11660.7 & 11660.7 & 11660.7 \\ 5552.2 & 5555.2 & 5552.2 & 5552.7 & 5552: 2 \\ 3649.7 & 3649.0 & 3649.0 & 3649.0 & 36.49 .0\end{array}$}

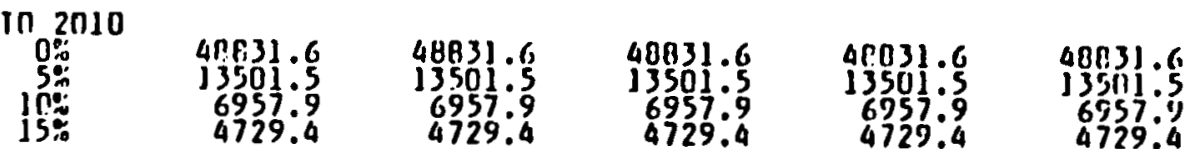

$\begin{array}{crrrrr}102020 & & & & \\ 050 & 42766.7 & 42766.7 & 42766.7 & 42766.7 & 42766.7 \\ 550 & 14017.7 & 34017.7 & 14017.7 & 14017.7 & 14017.7 \\ 1000 & 7504.6 & 7504.6 & 7504.6 & 7504.6 & 7504.6 \\ 15 \% & 5145.6 & 5165.6 & 5145.6 & 5145.6 & 5145.6\end{array}$

HIALIH \& ENVIRON - CNISSIONS \& EFFECIS

\begin{tabular}{|c|c|c|c|c|c|c|}
\hline $\begin{array}{l}\text { YEAR } \\
3975 \\
1980 \\
3985 \\
1990 \\
2000 \\
2010 \\
2020 \\
2040\end{array}$ & $\begin{array}{r}\text { POP EXP } \\
E 3 \\
\text { MAN REM } \\
34.31 \\
46.17 \\
100.90 \\
217.62 \\
240.53 \\
329.40 \\
356.40 \\
367.20 \\
367.20 \\
367.20\end{array}$ & $\begin{array}{r}\text { KR-8S } \\
\text { E6 } \\
\text { CUR1ES } \\
13.04 \\
42.07 \\
92.00 \\
198.28 \\
255.59 \\
310.12 \\
324.72 \\
334.56 \\
334.56 \\
334.56\end{array}$ & $\begin{array}{r}\text { IR! T } \\
\text { CUR5 } \\
\text { CUR Ifs } \\
4.666 \\
1: 05 \\
32.91 \\
70.93 \\
91.43 \\
107.36 \\
116.16 \\
19.60 \\
119.60 \\
119.68\end{array}$ & $\begin{array}{l}\text { RAD WASIE } \\
\text { ES } \\
\text { CII } 51 \\
2.92 \\
99.41 \\
2 \pi .57 \\
44.33 \\
57.15 \\
67.10 \\
72.60 \\
74.10 \\
74.100 \\
74.80\end{array}$ & 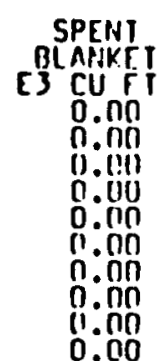 & (SHAMC) \\
\hline
\end{tabular}

\begin{tabular}{|c|c|c|c|c|c|}
\hline $\begin{array}{l}\text { YEAR } \\
1975 \\
1980 \\
1985 \\
1990 \\
2000 \\
2010 \\
2020 \\
2040 \\
21160 \\
2075\end{array}$ & $\begin{array}{c}\text { CO2 } \\
\text { E9TONS } \\
5.67 \\
6.53 \\
7.73 \\
8.80 \\
9.79 \\
10.96 \\
10.79 \\
10.95 \\
10.95 \\
10.95\end{array}$ & $\begin{array}{c}\text { CO } \\
\text { CR TONS } \\
8.32 \\
y: 10 \\
10.62 \\
13.99 \\
14.25 \\
15.21 \\
15.99 \\
16.26 \\
16.26 \\
16.26\end{array}$ & 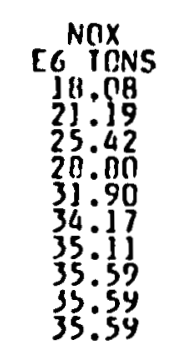 & $\begin{array}{c}\text { SU2 } \\
\text { E6 } 10 \mathrm{NS} \\
34.12 \\
16: 91 \\
21: 16 \\
24.56 \\
27.81 \\
30.12 \\
30.14 \\
31: 15 \\
31: 15 \\
31.15\end{array}$ & $\begin{array}{c}\text { PAl: } \\
\text { F6 PnNS } \\
0.36 \\
9: 96 \\
12: 907 \\
16: 77 \\
20.79 \\
23: 49 \\
24: 20 \\
24: 38 \\
24: 313 \\
24.38\end{array}$ \\
\hline 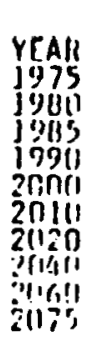 & 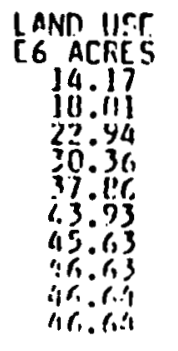 & $\begin{array}{c}\text { M1115 } \\
\text { E.3 } \\
1.34 \\
3.54 \\
1.96 \\
2.38 \\
3.25 \\
3.95 \\
3.92 \\
1.52 \\
4.117 \\
4.018\end{array}$ & 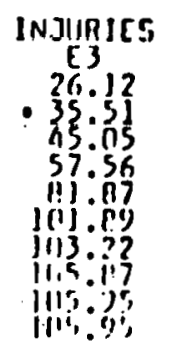 & 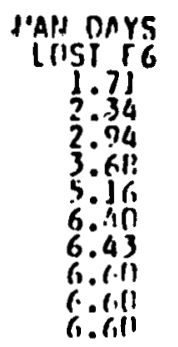 & 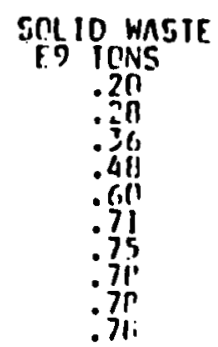 \\
\hline
\end{tabular}

Figure 2-5. (Continued) 
From this annual figure, calculated for each of the 100 years, a cumulative "present value" cost figure is calculated for each of several discount rates and starting dates. The different discount rates bracket the many notions that arise in assessment of social investments, involving issues ranging from interest rates to intergenerational responstbility. The different starting dates allow a glimpse at how the situation will look to future decision makers. This entire matter of discounting is discussed in greater detail in Appendix A.

- Cumulative consumption of key resources 18 shown for varlous time lintervals.

- Health and Environmental Emissions and Effects are calculated.

\section{F. Cost and Environmental Coefficients}

The code TPRESG is equipped to handle five sets of cost assumptions simultaneously. Each set can have costs that are constant or time varying over the 100-year perfod. It was decided to keep cost data fairly simple. Obviously, the cost parameter apace is large; some simplifying assumptions were needed. Most costs were kept constant in time. Exceptions were: 1) coal (at the minemouth) whose cost varled linearly from $\$ 1 / 10^{6}$ BTU to $\$ 4 / 10^{6}$ BTU from 1975 to 2075, 2) o1l and gas, from $\$ 2.00$ to $\$ 5.50$ over the same interval, 3) fission fuel, which nearly doubles between now and 2000 and rises more slowly thereafter, and 4) the fusion plant capital cost, discussed below. Table 2-2 summarizes these cost assumptions. Generally, the figures were adapted from cost eatmates used in related BNL energy modeling. FUSION CAPITAL COST AND LEARNING CURVES

The different cost sets in TPRESG were used to study the sensitivity of system cost to different possible time trends of the fusion capital cost. 
TABLE 2-2

COST ASSUMPTIONS

(1975 Dollars)

Electrical Generation

- CTR
- Renewable
- Fission
- Coal Steam
- Oil and Gas Steam
- Trans. and Dist.

Resource $\left(\$ / 10^{6} \mathrm{BTU}\right)$

- Coal (at mine)

Coal Transport

- $0 i 1$ and Gas

- Synfuels:

$$
\begin{array}{lcl}
\text { Capital } & 0 & \text { M } \\
(\$ / k w) & \left(\$ / 10^{6}\right. & \text { BTUe })
\end{array}
$$
(a)
0.40

600 (b)

1.00

600

0.40

450

0.50

300

0.25

250

0.52
$\$ 0.12$

$(2.00,1975),(\$ 5.50,2075) *$

$\$ 2.00$

$\$ 0.40$

CTR Fuel ( $\$ / 10^{6}$ BTUe) $\$ \$ 0.20$

Fisston Fuel $\left(\$ / 10^{6}\right.$ BTUe $)(\$ 1.25,1975),(\$ 2.40,2000),(\$ 2.70,2020) \stackrel{\star}{\star}$

(a) See Figure 2-6 and Table 2-3.

* Time varying costs entered as series of points (Amount, Year), connected by straight lines by the program.

** Cost from 2020-2075 is constant at $\$ 2.70$.

(b) See Table 2-3 for long-range solar electric cost assumption. 
Figure 2-6 shows the values used, based on the premise that the cost of the earliest commercial fusion plants could be very high (HIGH) or only moderately higher than LWR's (LOW), and that the rate of learning, as reflected in a subsequent drop in costs, could be FAST or SLOW. The first three sets apply in the nominal fusion implementation schedule used in most of the scenarios. The last two were reserved for examination of the implications of accelerated availablitity of commercial fusion. (See Table 2-3)

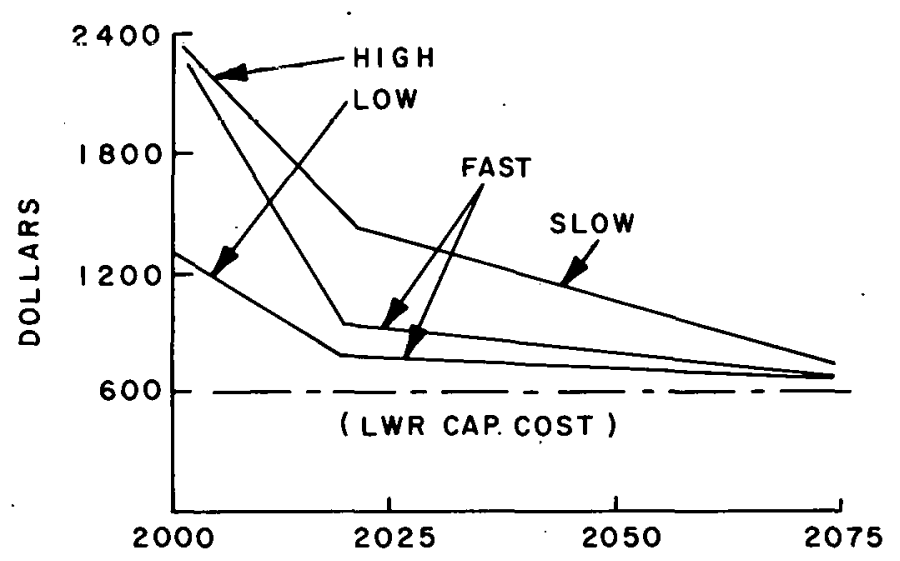

Figure 2-6. Fusion capital cost learning curves.

No attempt was made to use the various engineering estimates of fusion reactor costs (the "reference designs") because it is far too early to describe in detail the reactors that will actually be build 30 to 100 years from now. Instead a strictly parametric approach was taken. Commercially viable reactors will by definition be approximately competitive.

The Energy Model Data Base (EMDB) provides speciflc coefficients at the individual process level for various emissions and effects resulting from 
TABLE 2-3

Fusion Capital Costs

Learning Curves

$(\$ / \mathrm{kw})$

\begin{tabular}{l|c|c|c|c|c}
\hline Set \# & $\begin{array}{c}\text { Initial } \\
\text { Cost }\end{array}$ & $\begin{array}{c}\text { Learning } \\
\text { Curve }\end{array}$ & Cost (yr) & Cost (yr) & Cost (yr) \\
\hline Set 1 & HI & Slow & $\$ 2400(2000)$ & $\$ 1440(2020)$ & $\$ 760(2075)$ \\
Set 2 & HI & Fast & $\$ 2400(2000)$ & $\$ 1000(2020)$ & $\$ 650(2050)$ \\
Set 3 & LO & Fast & $\$ 1600(2000)$ & $\$ 750(2020)$ & $\$ 650(2025)$ \\
Set 4 & (HI & Fast & $\$ 2400(1990)$ & $\$ 1000(2010)$ & $\$ 650(2040)$ \\
Set 5 & Last & $\$ 1600(1990)$ & $\$ 750(2010)$ & $\$ 650(2040)$ \\
\hline
\end{tabular}

* Shifted ten years earlier, for accelerated CTR implementation schedule.

**The near term figure reflects Hydropower, while the 21 st century figures characterize central station solar electric as a backstop technology of assured feasibility at high cost (Feasibility at competitive costs is not proven). 
energy conversion and use activities. ${ }^{10}$ These coefficlents are in the form of tons of pollutant, or injuries, per BTU of energy flow. Values for the coefficients, presented in Appendix $C$, were taken from the Data Base with an attempt to select the most representative or reasonable estimates for the more aggregated energy flow activities in TPRESG, but it is not possible to establish truly meaningful coefficients at that level of aggregation because the individual technologies vary greatly in their characteristic emissions. Furthermore, the use of constant coefficients over 100 years is not entirely justifled: the extensive deployment of a technology will presumably go hand in hand with improved emissions control. Nevertheless, resulting totals should give an approximate feeling for the relative burdens to the environment imposed in the different scenarios. 
Notes to Chapter 2

1. For this particular aspect of the study, methods and results do not bear separating into respective chapters, and are presented together here.

2. This refers to the innumerable points that can be raised such as coal miners lives saved, or reduction of $\mathrm{SO}_{2}$ emissions, or elimination of plutonium accident risk, or the increased national security of energy independence, etc.

3. The purview might have been broader, introducing complicated issues such as the impact of energy on lifestyle and the economy, but it certainly cannot be narrower. The interconnectedness of energy resource use could not be adequately reflected, say, in an analysis of just the electrical sector, because the degree of electrification is a significant variable.

4. In optimization modeling, the technology mix is mathematically determined according to the criterion of minimum total system cost. Calculations are performed for a set of constraint equations which constitute a model of the energy system, and results are determined by the unit cost coefficients that are input to the model. This has two consequences. First, the number of input variables that have to be estimated is increased. Figures for supply, resource, and technology limits are still needed, in addition to cost figures.

Secondly, the "once-removed" character of the framework, where costs "drive the model", can obscure the fact that the resulting implementation levels have actually been determined by the cost assumptions in a way only slightly less arbitrary than exogenously fixing the implementation levels themselves.

Furthermore, costs, whether in the form of direct figures or elasticities or supply curves, cannot be easily established with any degree of reliability even for the near term, much less the very far term. Costs would, therefore, join with the other variables whose possible ranges require parametric treatment.

5. In this study, some of the possible ranges of both implementation levels and costs were in fact explored, but the distinction is that no formal attempt was made to model their influence on each other.

6. The term "demand" ( In economics a quantity which can be different from supply) here is used interchangeably with the term "consumption", the amount of energy consumed in a given year is equal to the amount provided.

7. H. Davitian, private communication.

8. If only two choices are available for each of five varlables, this results in $2^{5}=32$ combinations to be considered. Many of these may not be feasible, however, such as cases where supply is not equal to demand, or where extreme or unrealistic situations are involved. 
9. Sourcebook for Energy Assessment, M. Beller, ed., BNL Report No. 50483.

10. Energy Model Data Base, User's Manual, Energy Environmental Group, BNL Report No. 19200 and 21545. 
Chapter 3

\section{RESULTS AND ANALYSES}

\section{A. Introduction}

Future scenarios of energy supply and demand are strongly constrained by simple arithmetic--total demand is equal to total supply, which in turn must equal the sum of individual contributing resources. If there are restrictions on one resource, either another resource must make up the difference or a reduced total results. Conversely, additional resources of one type can ease the need for others, or permit expanded total consumption. In the scenarios that follow, total consumption of primary resources was fixed by assumption, and various resource mixes were developed through objective and intultive judgment. As discussed in Chapter $2(D)$, each resource was assumed to contribute approximately according to one of its own individual possible supply-schedules, the rates of implementation, or retirement already having satisfied several criteria. In addition to the assumptions developed for the total demand and for each resource, 
a preselection of resource mix strategies was made.

The scenarios are summarized in Table 3-1. For the first several cases (H201-05), coal was allowed to take up the slack, sometimes reaching very high (and probably unattainable) annual consumption levels. In other cases, a limit was set on coal, and either some other resource was selected to take up the slack (HZ-06) or the total demand was reduced (MZ-01) to yield a more believable case.

In no case was fusion commercialized unless the breeder was not. And in most cases the breeder was held to a non-growth schedule. High long-term growth was permitted only if one of the advanced ("inexhaustible") technologies was available. The issue of fusion introduction data was examined under different assumptions about the availability of alternative resources (with and without imports).

\section{B. Resource Trade-offs and Cost/Benefit}

In Figure 3-1 the resource levels and total annual system costs are plotted as a function of time for cases $\mathrm{HZ}-01$ through HZ-05 (Detailed printouts appear in Appendix D). As supplies are tightened, if fusion is not introduced (\#1 - \#3), both the need for coal and the system cost increase. The introduction of fusion (\#4 and \#5) considerably eases both factors.

Coal Use

Table 3-2 shows the total coal use for all scenarios as compared with the current estimates for U.S. reserves and resources. That resources appear to be more than sufficient is not cause for casual opt1mism about rellance on coal, however. The immediate and cumulative impacts associated with annual production levels from several to over ten times the current rate would be considerable, even if such rates could be attained. 
TABLE 3-1

SUMMARY OF SCENARIOS

\begin{tabular}{|c|c|c|c|c|c|}
\hline SCENARIO & FUSION & IMP & FBR & COAL & COMMENTS \\
\hline $\mathrm{HZ}-0 \mathrm{I}$ & $\mathrm{N}$ & $\mathrm{Y}$ & $\mathbf{Y}$ & unlimited & Base case, with breeder and imports \\
\hline-02 & $N$ & $\mathbf{Y}$ & $\mathrm{N}$ & unlimited & Base case, but no breeder \\
\hline-03 & $\mathrm{~N}$ & $\mathrm{~N}$ & $\mathrm{~N}$ & unlimited & Base case, no breeder, no imports \\
\hline-04 & $\mathrm{Y}$ & $\mathrm{Y}$ & $\mathrm{N}$ & unlimited & Fusion! \\
\hline-05 & $\mathrm{Y}$ & $\mathrm{N}$ & $\mathrm{N}$ & unlimited & Fusion! \\
\hline-06 & $\mathrm{Y}$ & $\mathrm{N}$ & $\mathrm{N}$ & Iimited & Fusion, drastic case \\
\hline-07 & $\mathbf{Y}$ & $\mathrm{Y}$ & $\mathrm{N}$ & unlimited & Early Fusion - based on $\mathrm{HZ}-04$ \\
\hline-08 & $\mathrm{Y}$ & $\mathrm{N}$ & $\mathrm{N}$ & unlimited & Early Fusion - based on $\mathrm{HZ}-05$ \\
\hline $\mathrm{MZ}-0 \mathrm{I}$ & $\mathbf{Y}$ & N & $\mathrm{N}$ & $<60$ Quad/yr & Al1 Eusion (Mid-term demand revised from HZ-06) \\
\hline-02 & $\mathbf{N}$ & $\mathrm{N}$ & $\mathrm{N}$ & $<60$ Quad/yr & A11 Solar \\
\hline-03 & $\mathrm{~N}$ & $\mathbf{N}$ & $\mathrm{Y}$ & $<60$ Quad/yr & A11 FBR \\
\hline $\mathrm{HH}-01$ & $\mathbf{Y}$ & $\mathrm{Y}$ & $\mathrm{N}$ & unlimited & High Fusion \\
\hline-02 & $\mathrm{Y}$ & $\mathrm{N}$ & $\mathrm{N}$ & unlimited & V. High Fusion \\
\hline-03 & $\mathbf{N}$ & $\mathbb{N}$ & $\mathrm{N}$ & unlimited & V. High Solar \\
\hline-04 & $\mathbf{N}$ & $\mathrm{N}$ & $\mathrm{N}$ & unlimited & V. High FBR \\
\hline LZ -01 & $\mathbf{N}$ & $\mathrm{Y}$ & $\mathrm{Y}$ & & Base case \\
\hline 02 & $\mathbf{Y}$ & $\mathrm{Y}$ & $\mathrm{N}$ & & Eusion replaces FBR. \\
\hline
\end{tabular}



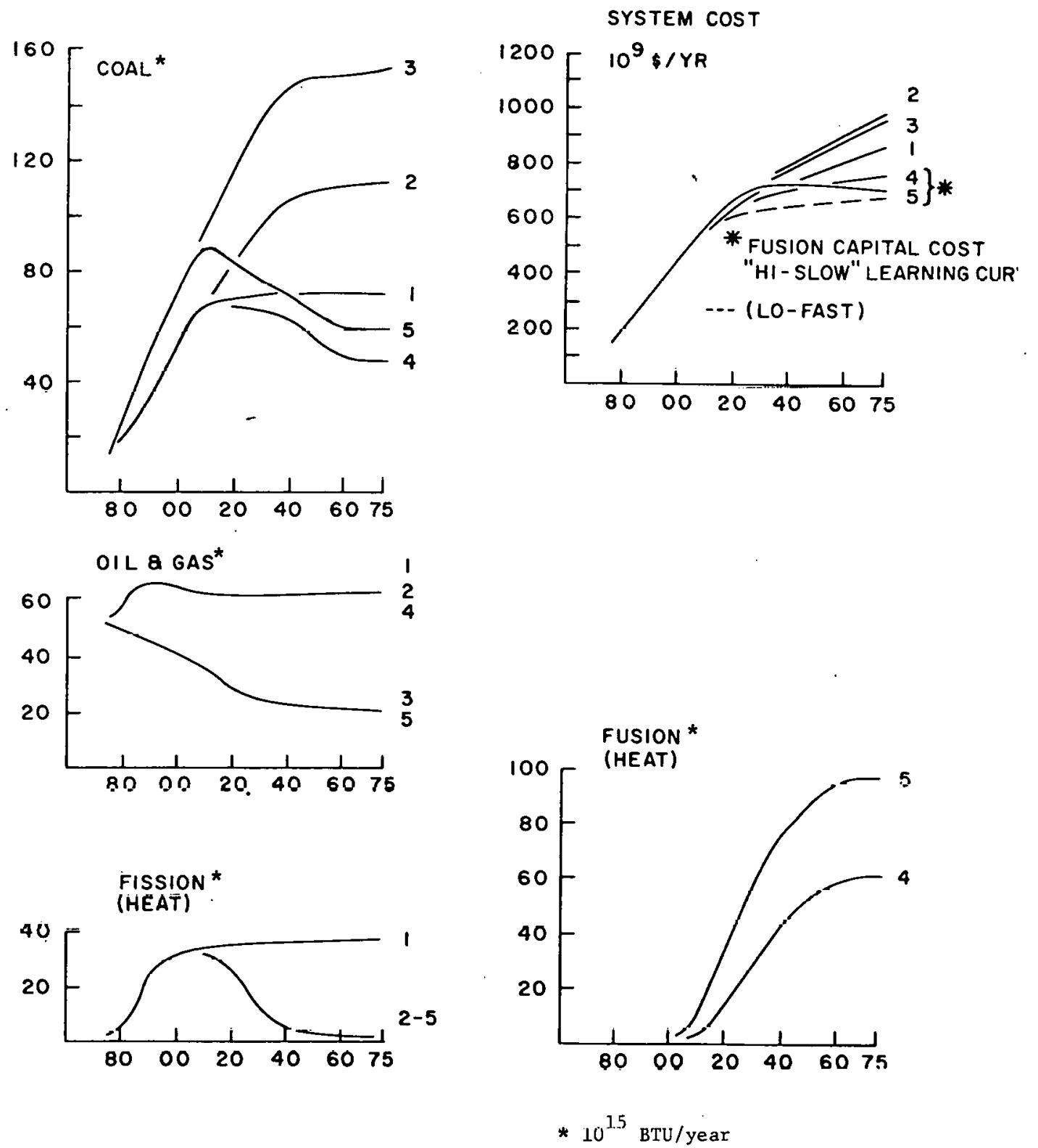

F1gure 3-1. Annual System Cost \& Resource Use Hi-Zeg (Hz) 
TOTAL CUMULATIVE FOSSIL RESOURCE USE

\begin{tabular}{|c|c|c|c|c|}
\hline \multirow[b]{2}{*}{ SCENARIO } & \multicolumn{2}{|c|}{$\begin{array}{l}\text { TOTAL COAL USE } \\
10^{18} \mathrm{BTU}\end{array}$} & \multicolumn{2}{|c|}{$\begin{array}{c}\text { TOTAL OIL \& GAS USE } \\
10^{18} \text { BTU }\end{array}$} \\
\hline & $1975-2025$ & $1975-2075$ & $1975-2025$ & $1975-2075$ \\
\hline $\mathrm{HZ}-01$ & 2.4 & 6.1 & 3.2 & 6.4 \\
\hline-02 & 2.5 & 8.0 & 3.2 & 6.4 \\
\hline-03 & 3.7 & 11.1 & 1.9 & 3.0 \\
\hline-04 & 2.4 & 5.3 & 3.2 & 6.4 \\
\hline-05 & 3.2 & 6.6 & 2.0 & 3.1 \\
\hline-06 & 2.5 & 5.2 & 1.9 & 3.0 \\
\hline-07 & 2.2 & 4.9 & 3.2 & 6.4 \\
\hline-08 & 2.9 & 6.0 & 2.0 & 3.1 \\
\hline$M Z-01$ & 2.3 & 5.0 & 1.9 & 3.0 \\
\hline-02 & 2.3 & 5.0 & 1.9 & 3.0 \\
\hline-03 & 2.3 & 5.0 & 1.9 & 3.0 \\
\hline $\mathrm{HH}-01$ & 2.4 & 5.3 & 3.2 & 6.4 \\
\hline-02 & 3.2 & 6.6 & 2.0 & 3.1 \\
\hline-03 & 3.2 & 6.6 & 2.0 & 3.1 \\
\hline-04 & 3.2 & 6.6 & 2.0 & 3.1 \\
\hline $\mathrm{LZ}-01$ & 1.7 & 4.1 & 2.4 & 4.5 \\
\hline \multirow[t]{2}{*}{-02} & 1.7 & 4.1 & 2.4 & 4.5 \\
\hline & $\begin{array}{l}\text { U.S. Pror } \\
\text { Remaining } \\
\text { Resou }\end{array}$ & $\begin{array}{l}\text { Reserves } \\
\text { ecoverable }\end{array}$ & \multicolumn{2}{|c|}{$\begin{array}{l}\text { * Includes proved reserves } \\
\text { and undiscoverable resources }\end{array}$} \\
\hline
\end{tabular}


TABLE 3-3

DISCDUNTED NET BENLFITS

HI - ZEG SCENARIO COMPARISONS

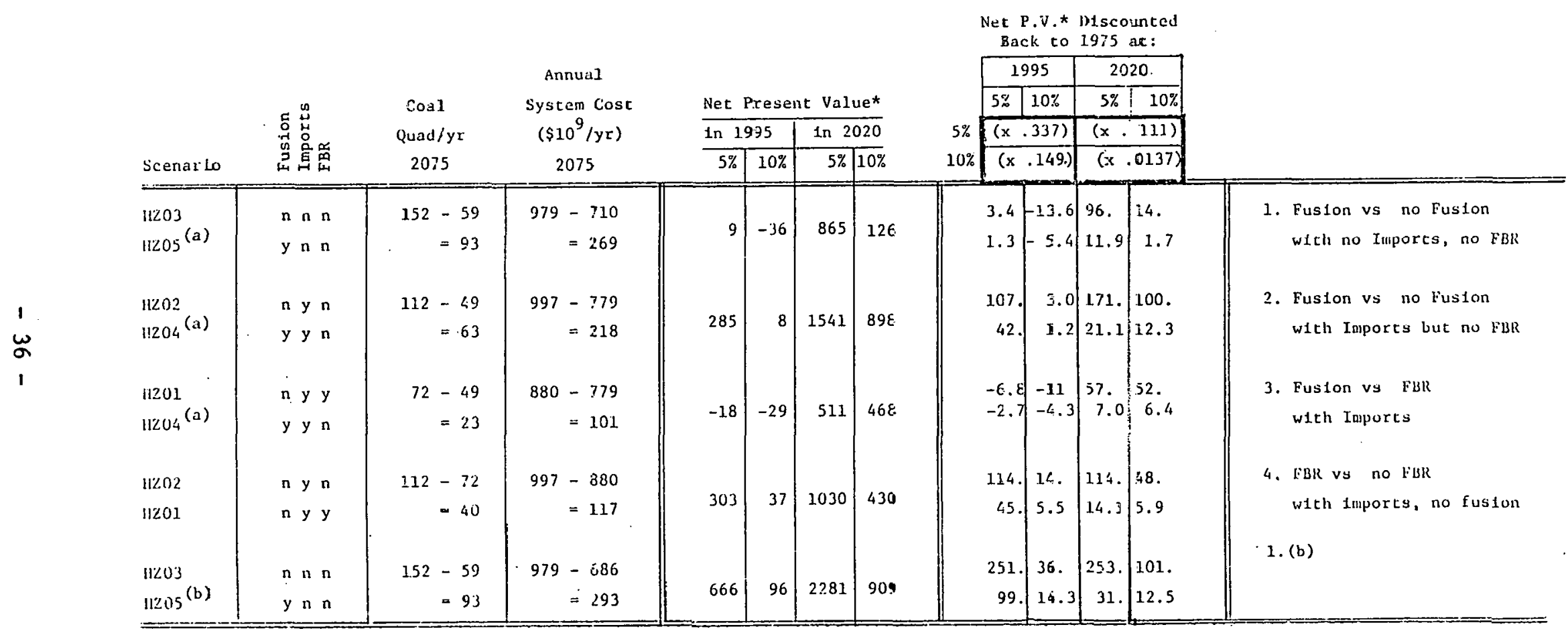

* Difference bezween cases in cunularive discourited total aunjal. systen cost, from st.ste yeat lidicated to 2075. $\left(\$ 1.0^{9}\right)$

(a) Fusior Capizal Cos = Leurning Curre: H1-Siow

(b) Fustur Capieal Cos: Learning Curme: Lo-Fast 


\section{Cost}

In the plot of annual system cost in Figure 3-1, possible trade-offs are apparent. Under the cost assumptions used, these resource mix scenarios show a high system cost late in the next century unless the investment is made to install fusion reactors (This is the investment at the point of commercialization from 2010 on--not the cost of research to be done between now and then.) It is just such an effort, with temporarily higher costs, that may be required to establish the more vast resource base which fusion makes available.

\section{Annual Cost Curves and Discounting}

Costs over time are not typically presented. Instead, the possibly complex shape of these curves is collapsed to a single parameter--the discounted present value, which is highly sensitive to the choice of discount rate and which narrowly confines the basis for decision. A discounting approach can indicate a preference for the nonfusion scenarios because they temporarily exhibit lower cost in the nearer timeframe. Of course, this takes no account of ultimately lower cost of a system, which moreover relies on an inexhaustible resource base (nor have the external benefits of avolding high coal use been considered).

This effect is apparent in Table 3-3, where detailed comparisons among the $\mathrm{HZ}$ scenarios are given. For example, HZ-03 vs. HZ-05 compares a fusion vs. no fusion case, aosuming no imports and no breeder. The use of fuston saves 93 Quads of coal per year by 2075, and the annual system cost is down by $\$ 269$ billion. Discounted net present values are also shown. First, for two starting dates and two values of the discount rate, the net difference is shown in the cumulative discounted system cost, from the start date out to 2075. Finally, those figures are discounted back to 1975, at two different rates, giving for each comparison eight different estimates of the net present value ${ }^{2}$ (of fusion) in 1975. 
The most noteworthy feature of these numbers is their extreme yariability. The 2020 figures reflect only the large wedge of long-term savings due to fusion, but the 1990 figures are dominated by the temporarily higher costs around 2010 . Within each comparison the net benefits can range from minus $\$ 5$ to 10 billion to plus $\$ 100$ to 200 billion, depending on discount rates. For any one given set of discount rates, the variability among comparisons is somewhat less. A conclusion from this is that the effect of discount rate on results is as great or greater than any effect due to resource mix or cost assumptions, verifying that the level of detail and specificity in the model and data are indeed appropriate, that is to say that they are commensurate with the influence that the discount rate has on results.

The "HIGH-HIGH" cases are shown on Figure 3-2 and compared with the corresponding fusion scenarios of the "HIGH-ZEG" cases. It was assumed that energy growth would be renewed in the twenty-first century only if fusion proved successful. But these high growth rates do begin to press against the realistic scale of things mentfoned above. For example, in the scenario with imports (HHO1), the fusion electrical generation is $22.5 \mathrm{mQ}$ in 2040 and $49.0 \mathrm{mQ}$ in 2060 . This corresponds to 630 and 1370 plants (@ $1500 \mathrm{MW}$ ) respectively. ${ }^{3}$ The 740 plants to be added in those two decades would have to be brought on line at an average rate of three per month! Finding sites alone would be problematic, much less the capital, manpower, and materials. Current U.S. capacity of all types would be equivalent to only 317 plants (@ $1500 \mathrm{MW}$ ).

The electrification ratio implied here should be noted. Unless fusion heat can be effectively converted to liquid or gas fuels, this degree of reliance on fusion implies a drastically increased proportion of electrical end-use devices. 

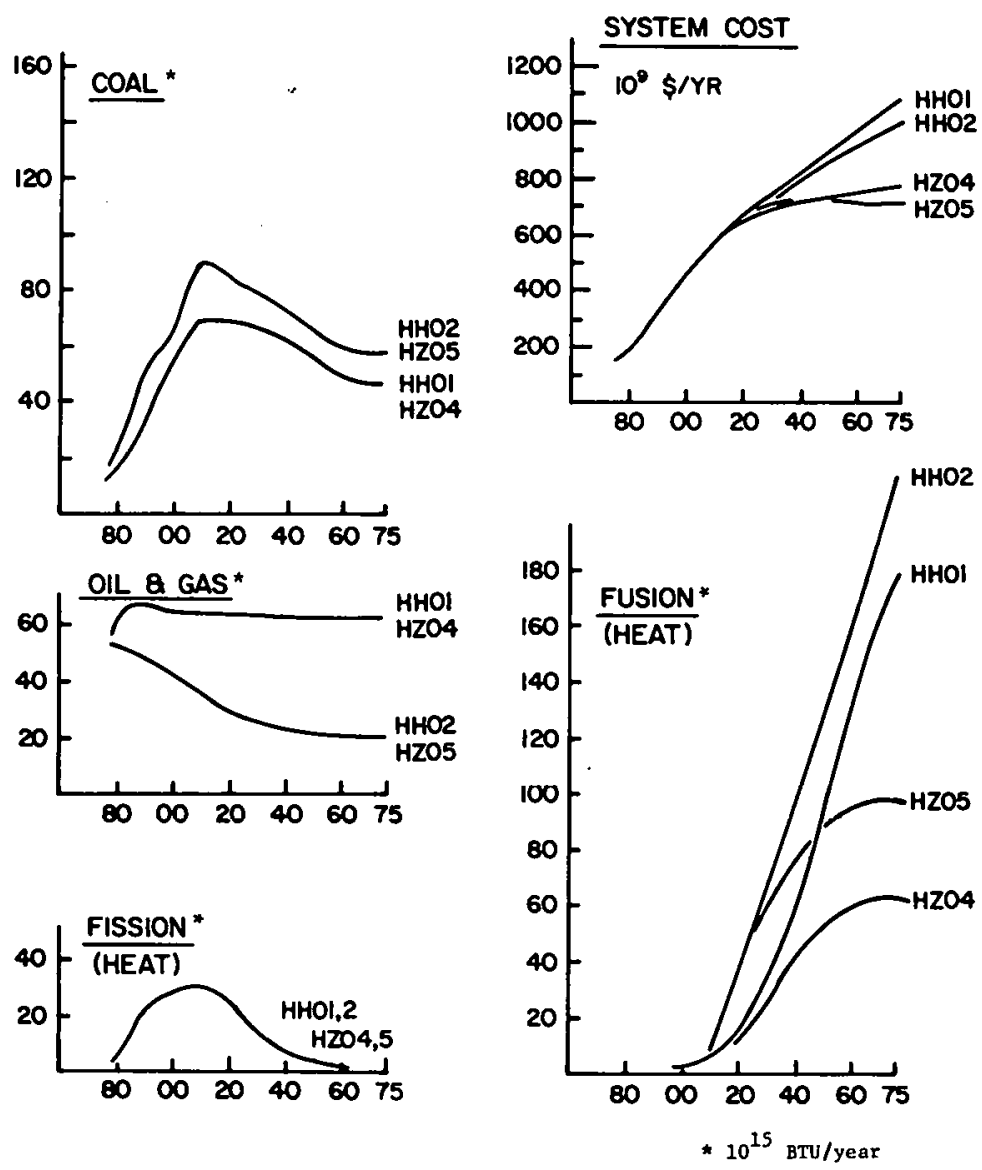

Figure 3-2. Annual system cost \& resource use High-High (HH). 


\section{Drastic Limits}

A "worst case" with respect.to alternatives for energy supply would involve: 1) a limit to annual coal production (not to exceed 60 quad/year, which is 5 times current production), 2) unavailability of oil and gas imports, and 3) a

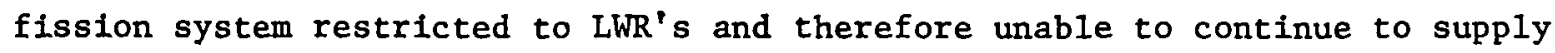
energy after the exhaustion of uranium. An attempt to match these supply schedules to the $\mathrm{HZ}$ demand case leads to an extraordinary requirement for the introduction of fusion and/or solar technologies. In Figure 3-3 a probably unachievable amount of solar was required to match supply and demand under these assumptions (the HZ-06 case). Instead, a new demand case was indicated, which fortuitous1y reflected a trend evident in new projections currently under development for Planning and Analysis of ERDA. Figure 3-4 shows this new MZ (M for "middle") demand scenario which has a lower profile in the mid term (1980 - 2025 approximately), though it reaches the same ultimate long-term rate of primary resource consumption ( 170 quad/year). Also shown for comparison are preliminary values for the F-2 and F-4 ERDA forecasts. ${ }^{4}$ The MZ demand scenario allows a slightly less drastic growth rate in coal production, and a more reasonable (attainable) schedule for the introduction of solar and fusion.

\section{Basic Long-Range Alternatives}

There are three basic alternatives for energy supply in the very long term. Only fusion, solar, and breeder fisstion technologies offer access to resources that are essentially inexhaustible. Each, however, suffers from serious limitations. Fusion has yet to be proven feasible. Solar (central station electric) may be technically feasible but is not economically feasible. Fission carries a now familiar host of acceptability problems, which may far outweigh any possible (though by no means assured) ecomomic advantage. 
- HZO6

- $\mathrm{MZOI}$
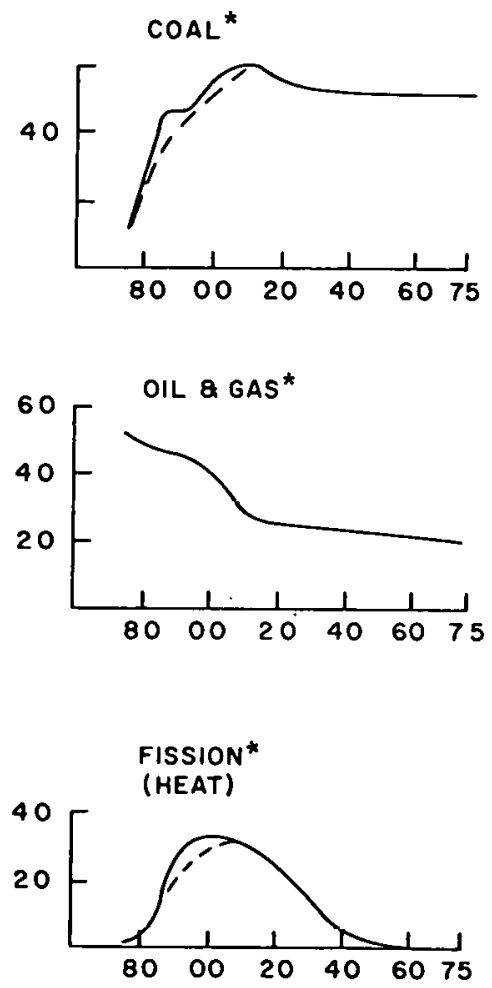
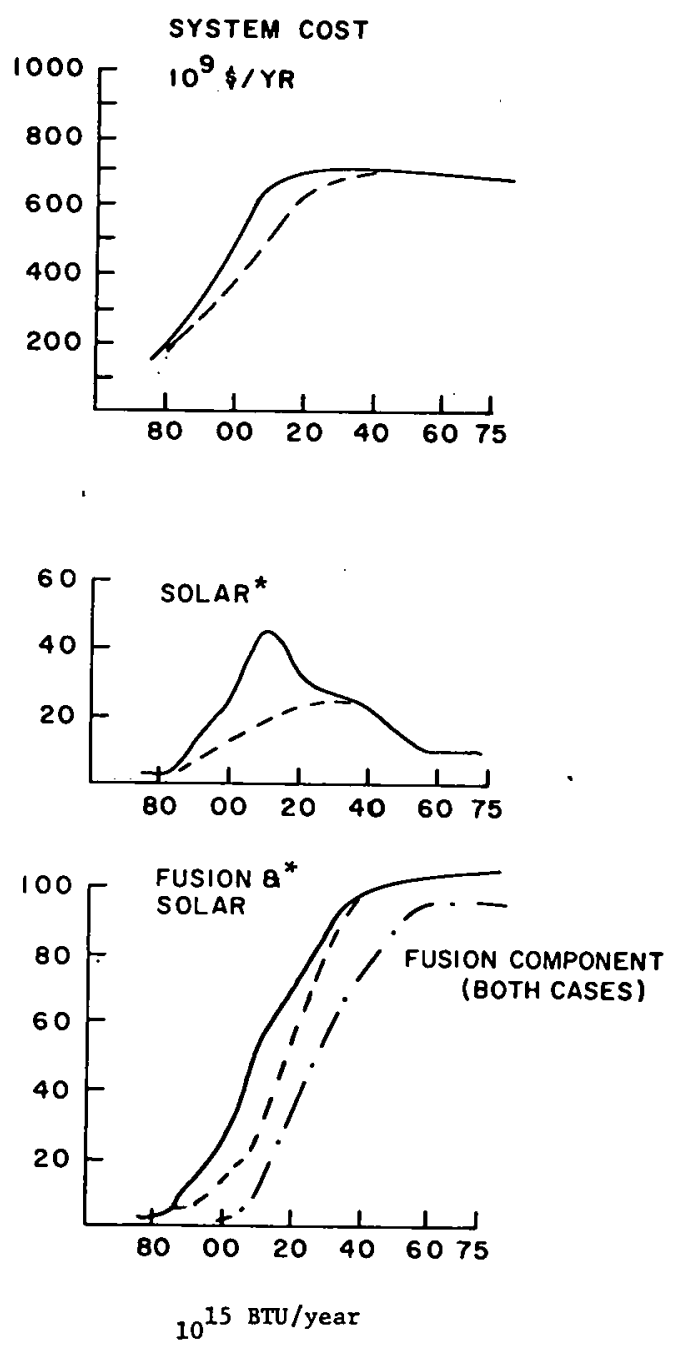

Figure 3-3. Annual system cost \& resource use drastic limits. 


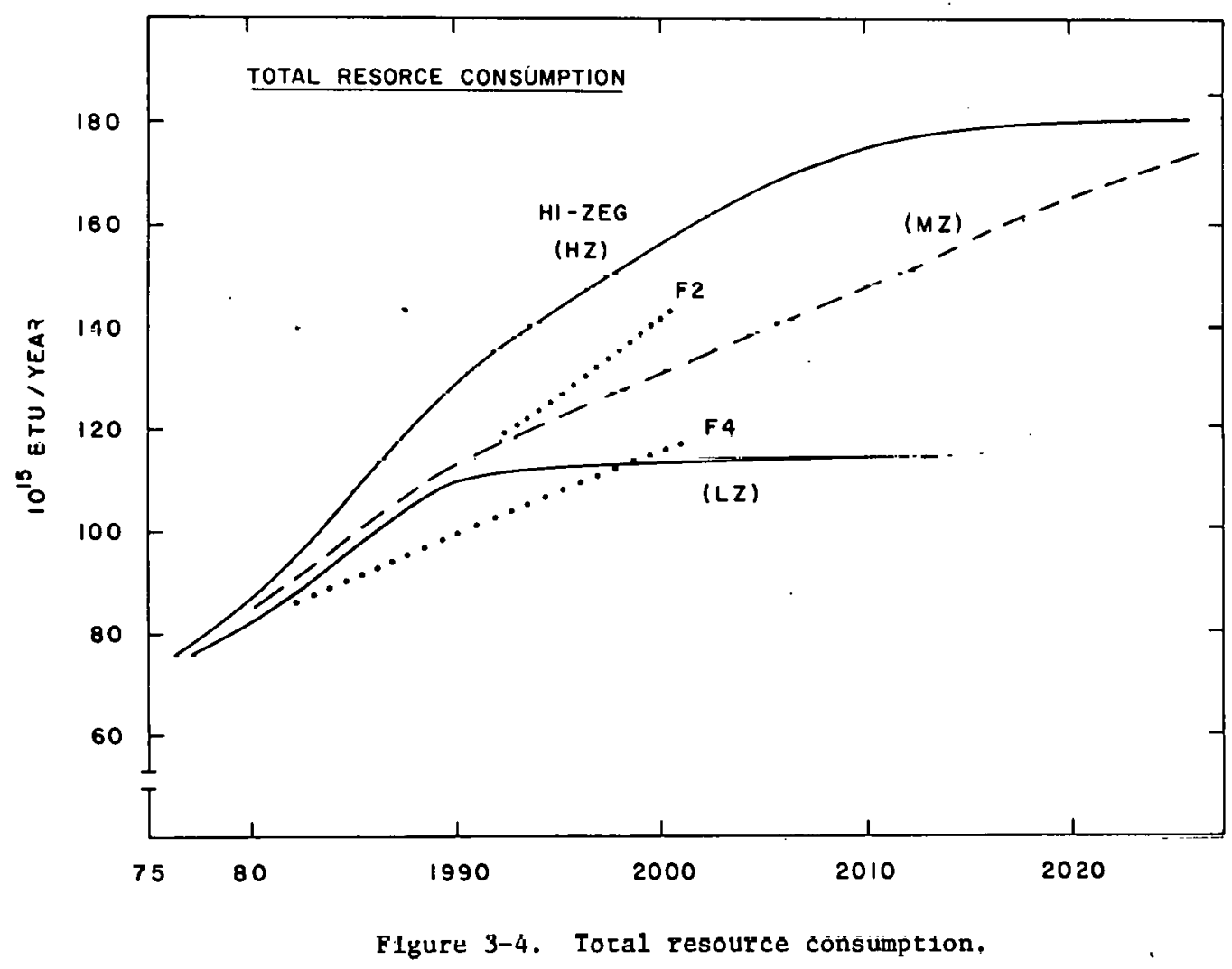


Figure 3-5 and 3-6 show scenarios in which each alternative long-range technology is taken in turn to provide the bulk of energy supply in the 21 st century. Again, simple arithmetic dictates that if one resource is not to be available, another must take its place if a given total consumption is to be maintained. Here the three technologies have not been characterized in any great detail. The principal distinguishing feature in these scenarios is cost, where assumptions are as given in Table 2-3. Solar is described as a backstop technology which will very probably be available at the high cost of $\$ 2000 / \mathrm{kW}$. Fission encounters a gradually rising fuel cost, and the fusion capital cost falls along the learning curves shown previously in Figure 2-6. Additional distinctions are evident in the health and environmental effects, however, detailed conclusions should not be drawn from the totals which result because of the level of aggregation [see Chapter 2(F)].

The total land use result in 2075 is nominally $50 \times 10^{6}$ acre/yr for the MZ cases, and $86 \times 10^{6}$ acre/yr for the $\mathrm{HH}$ cases. This figure is increased by $6 \times 10^{6}$ acres and $13 \times 10^{6}$ acres respectively by the dominant use of solar $\left(10^{4}\right.$ and $2 \times 10^{4}$ $\mathrm{mi}^{2}$, an area equal to the state of New Hampshire, or New Hampshire and Vermont combined). The effect is not as large as might be expected because electrical transmission and distribution land use dominates the land use by electric utilities.

\section{LAND USE (ACRES/1000 MWe)}

PLANT $\quad$ TOTAL

Coal Steam

Uil Steam

Nuclear

Fusion

Solar

Trans. \& Dist.
17200
17600

17315

17514

$1 \% 514$

21700 

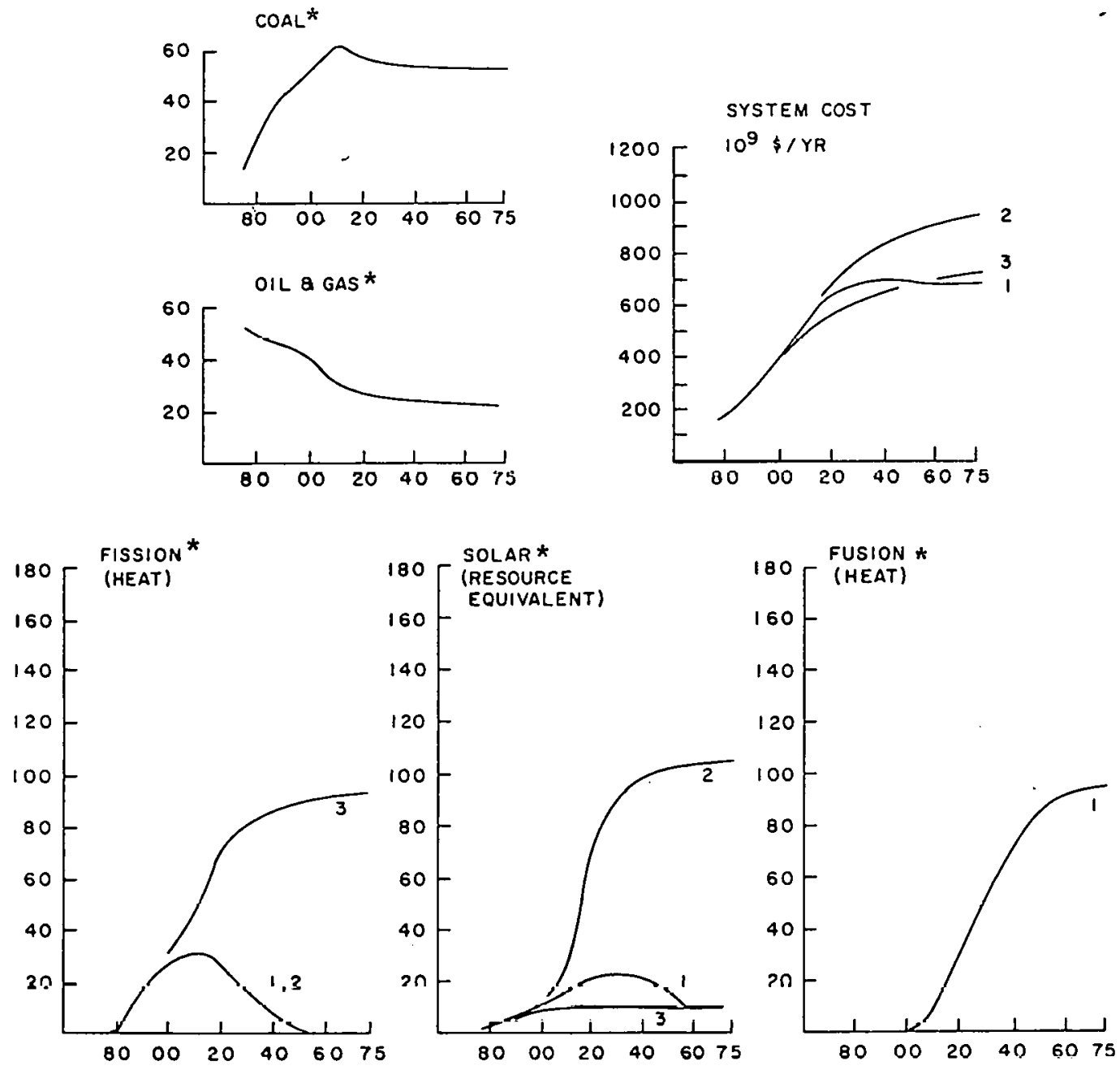

* $10^{15} \mathrm{BTU} /$ year

Figure 3-5. Annual system cost \& resource use

Long range alternatives MZ01 Fusion

MZ02 Solar

MZ03 FBR 

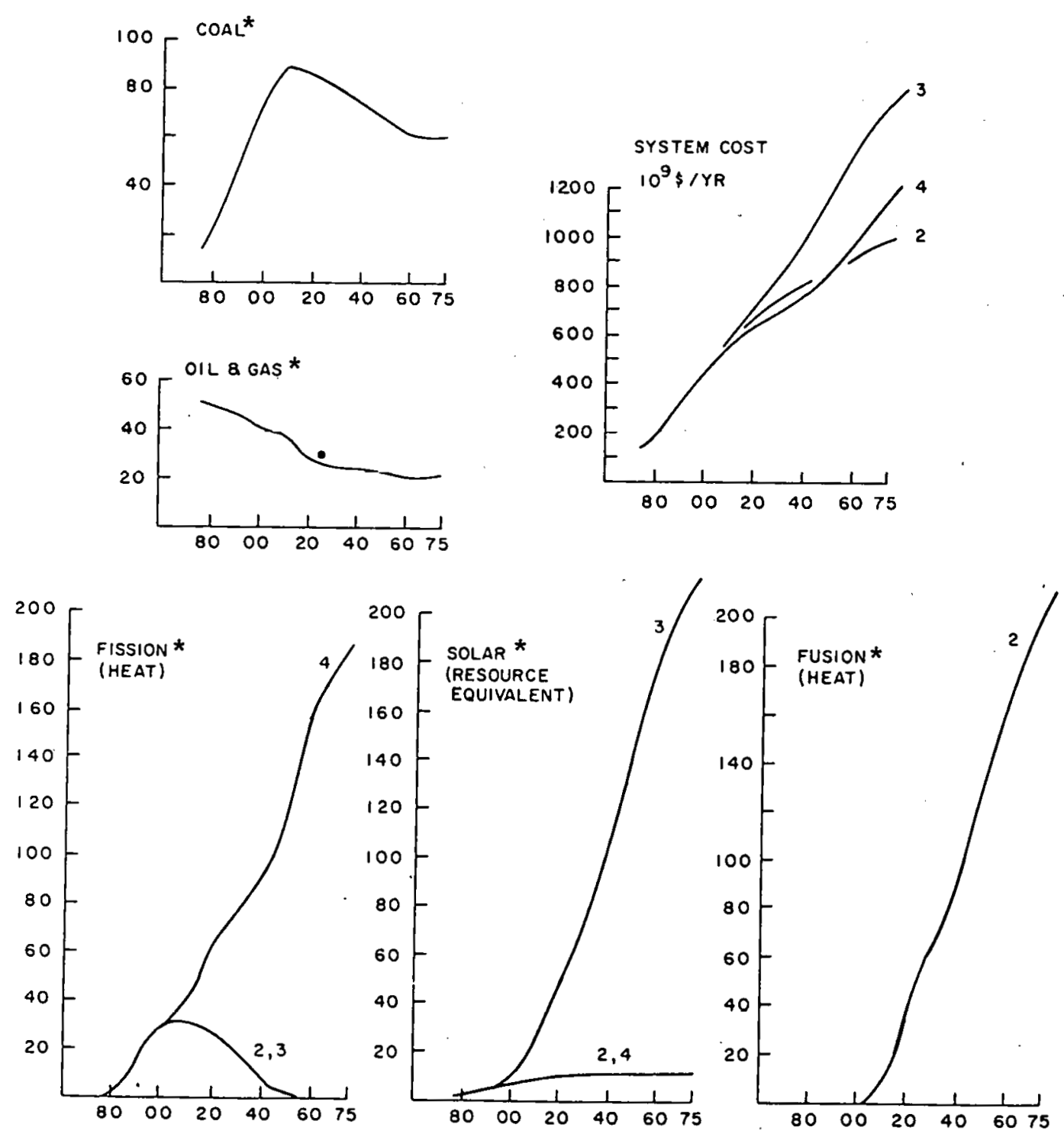

* $10^{15} \mathrm{BTU} /$ year

Figure 3-6. Annual system cost \& resource use Long range alternatives HH02 Fusion

HH03 Solar

HH04 FBR 


\section{E. Early Implementation of Fusion}

Assuming that it might be possible to accelerate the fusion $\mathrm{RD} \& \mathrm{D}$ program so that growth in commercialization could begin earlier, it is interesting to examine the extent of resulting benefits. Figures 3-7 and 3-8 show comparisons between "nominal" fusion introduction, which reaches a significant (10 quads) leve1 by 2010, and "early" fusion, where that same curve is shifted 10 years earlier. For the case with imports (Figure $3-7$ ) and without imports (Figure $3-8$ ), the earlier fusion energy was used to displace some of the need for coal and fission. In both comparisons a substantially lower system cost results, and this savings depends only slightly on the fusion capital cost learning curve assumption ("HI-FAST" vs. "LO-FAST") .

Table 3-4 indicates the differences in discounted present value. The net benefit of early introduction, though of course strongly dependent on the choice of discount rate, is nevertheless robust and may be indicative of current $R \& D$ spending levels that would be appropriate to bring about early introduction.

\section{F. Cost Sensitivity}

Since coal is assumed to be a major energy supply and the principal alternative to fusion, its cost and utilization levels will have the greatest effect on the total system cost. The sensitivity of results to assumptions made about the future of coal costs was examined.

All scenarios were run under the cost assumptions shown in Table 2-3. The cost of coal was presumed to rise linearly from $\$ 1$ in 1975 to $\$ 4$ in 2075 ( $\left.\$ / 10^{6} \mathrm{BTU}\right)$, independently of development rate or cumulative resource depletion. A tool commonly used to describe the possible dependence of cost on such variables is the supply curve, where unit cost is plotted against the cumulative production. Time 

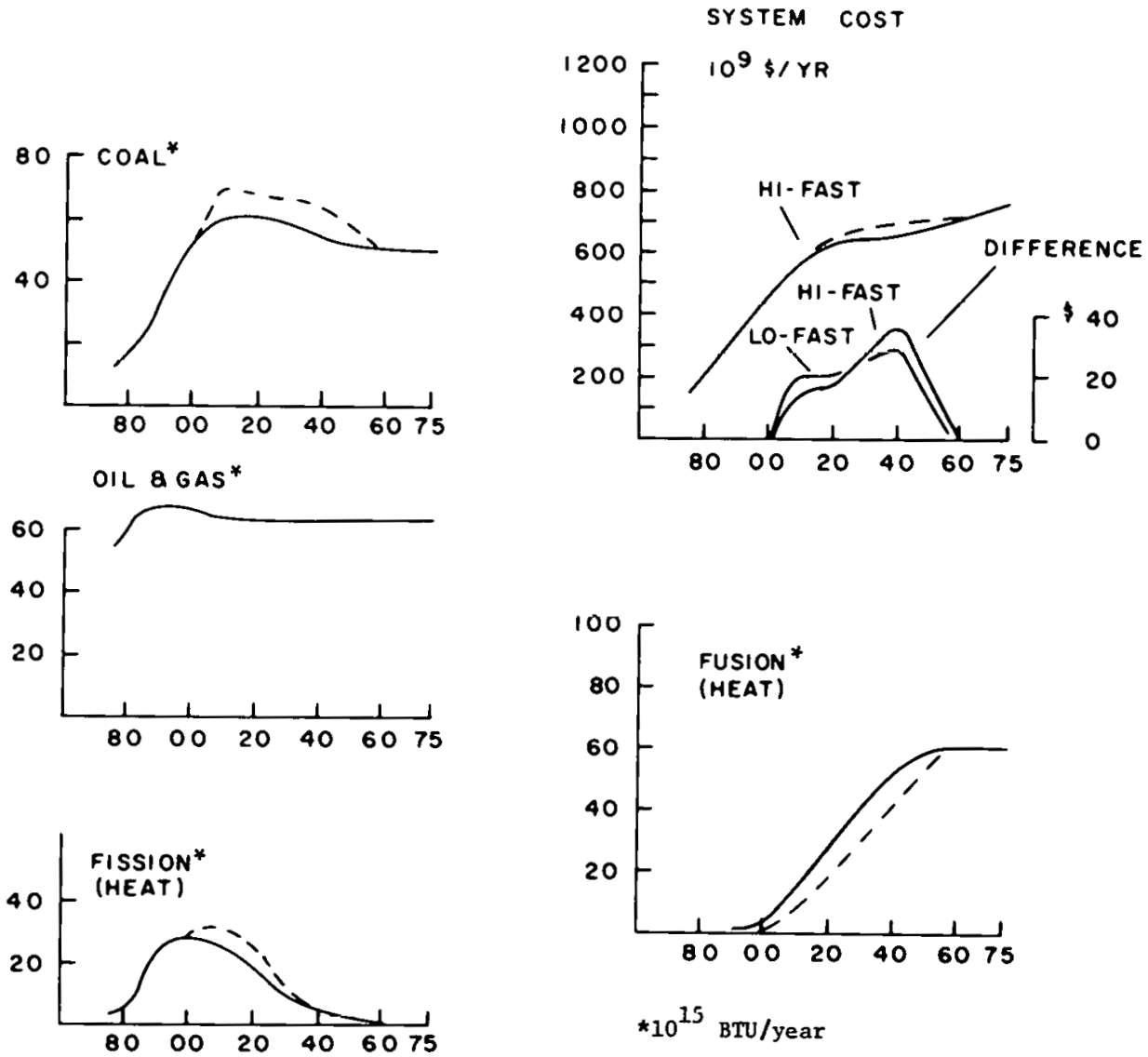

Figure 3-7. Annual system cost \& resource use Early implementation of fusion

- - HZ04 (Nomina1) HZO7 (Early) 

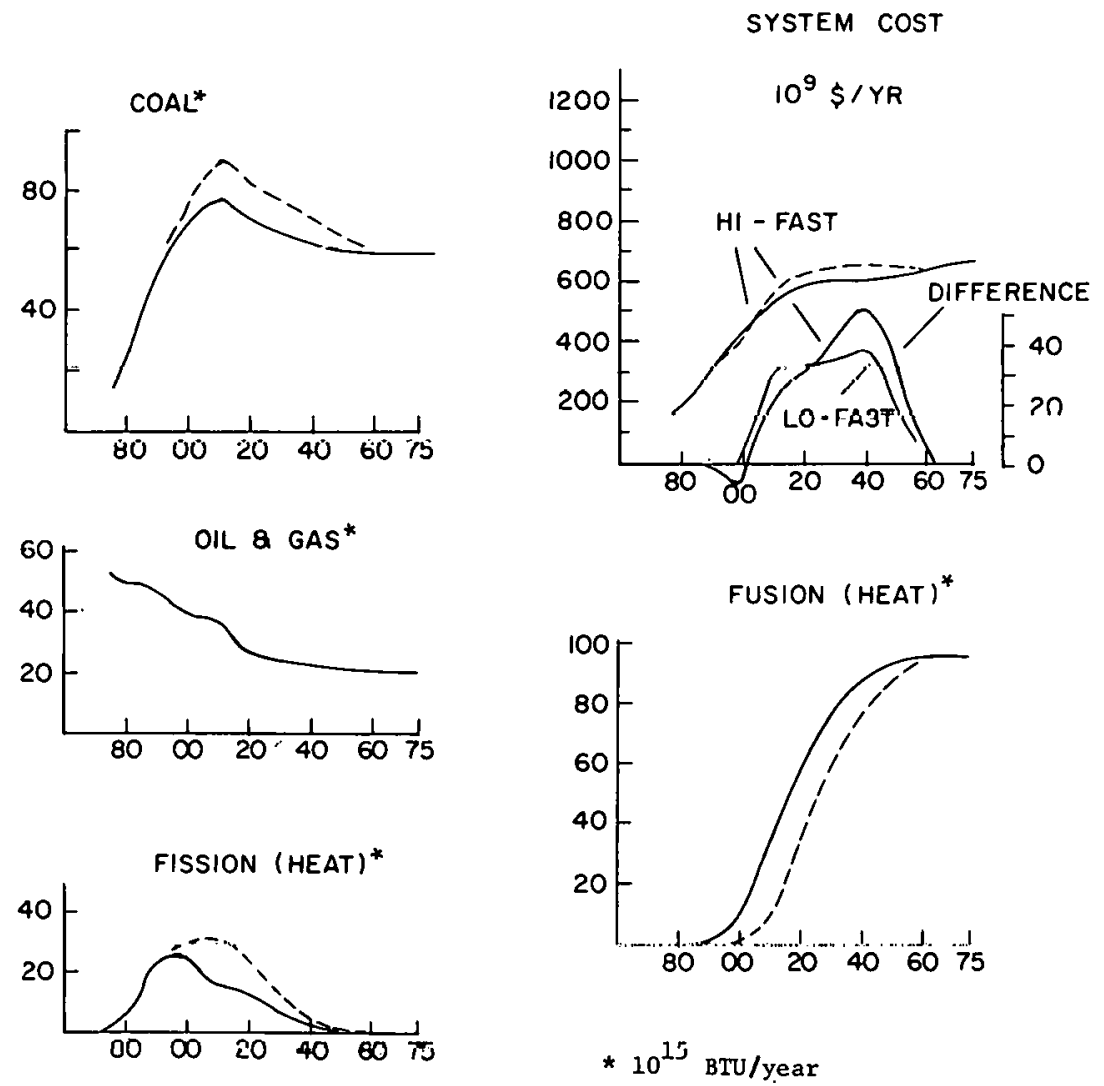

Figure 3-8. Annual system cost \& resource use Early implementation of fusion

- - H205 (Nomina1) Hz08 (Early) 
TABLE 3-4

CHANGE IN 1975 DISCOUNTED PRESENT VALUE

EARLY IMPLEMENTATION OF FUSION

[HZ08 (ear1y) minus HZ05 (nomina1)] (without imports)

\begin{tabular}{|c|c|c|c|c|c|c|}
\hline \multirow[b]{2}{*}{1975} & \multicolumn{2}{|r|}{ HI } & FAST & LO & \multicolumn{2}{|c|}{ FAST } \\
\hline & $0 \%$ & 1564 & & 1567 & & \\
\hline & $10 \%$ & & & & 16.6 & \\
\hline 1995 & $5 \%$ & 101 & $(268.3) *$ & 138 & & $(366)$. \\
\hline & $10 \%$ & & $(42.9)$ & & 18 & (121.) \\
\hline 2010 & $5 \%$ & 121 & $(669)$ & 119 & & $(656.6)$ \\
\hline & $10 \%$ & & (369) & & 14.1 & $(392.4)$ \\
\hline
\end{tabular}

[HZO7 (early) minus HZ04 (nominal)] (with imports)

\begin{tabular}{|c|c|c|c|c|c|c|}
\hline $197 j$ & $0 \%$ & \multicolumn{2}{|l|}{1059} & \multicolumn{3}{|c|}{10.6} \\
\hline 1995 & $5 \%$ & 74.6 & (198) & 88.6 & & (235.) \\
\hline & $10 \%$ & 7.4 & $(49.6)$ & & 11.4 & $(76.7)$ \\
\hline 010 & $5 \%$ & 73.4 & $(405.3)$ & 75.1 & & $(414.8)$ \\
\hline & $10 \%$ & 7.8 & $(216.5)$ & & 8.6 & $(238.9)$ \\
\hline
\end{tabular}

* Numbers in parentheses are discounted present values in the designated start year. 1975 values were obtained by straight discounting of this value.

** See Note?. 
is not an explicit variable. Thus, a given cost level will be reached at a given production level and not at some prespecified time.

Figure 3-9 shows the coal supply curves which are implied by the coal use and cost trajectories employed in the above scenarios. Notably, with the cost fixed with respect to time, differing amounts of resource used imply a more sharply rising supply curve for the lower utilization, and a more slowly rising curve for the higher utilization. This can be viewed in several ways. On one hand, it might be argued that this is indeed appropriate: Coal use would indeed be lower precisely when its supply curve rises more sharply. On the other hand, it might be argued that the opposite is true, and the lower coal use should involve lower, not higher costs. This, in fact, is the basis of using a supply curve to fix costs with respect to quantity rather than with respect to time.

Figure 3-9 indicates the effect that fixing the coal cost according to a supply curve has on the total system cost. It is pushed higher in the high coal (high cost) case and lower in the low coal case, when the extrapolated base case supply curve is used to determine the cost of coal.

\section{CTR Capital Cost Learning Curve}

The different cost sets in TPRESG were used to study the sensitivity of system cost to different possible time trends of the fusion capital cost. Table 2-3 shows the values used, based on the premise that the cost of the earliest commercial plants could be very high (HIGH) or low (LOW) only moderately higher than LWR's and that the rate of learning, as reflected in a subsequent drop in costs, could be fast or slow. The first three cost sets apply in the nominal fusion implementation schedule used in all the above scenarios. (The last two were used for the examination of accelerated availability of commercial fusion.) 

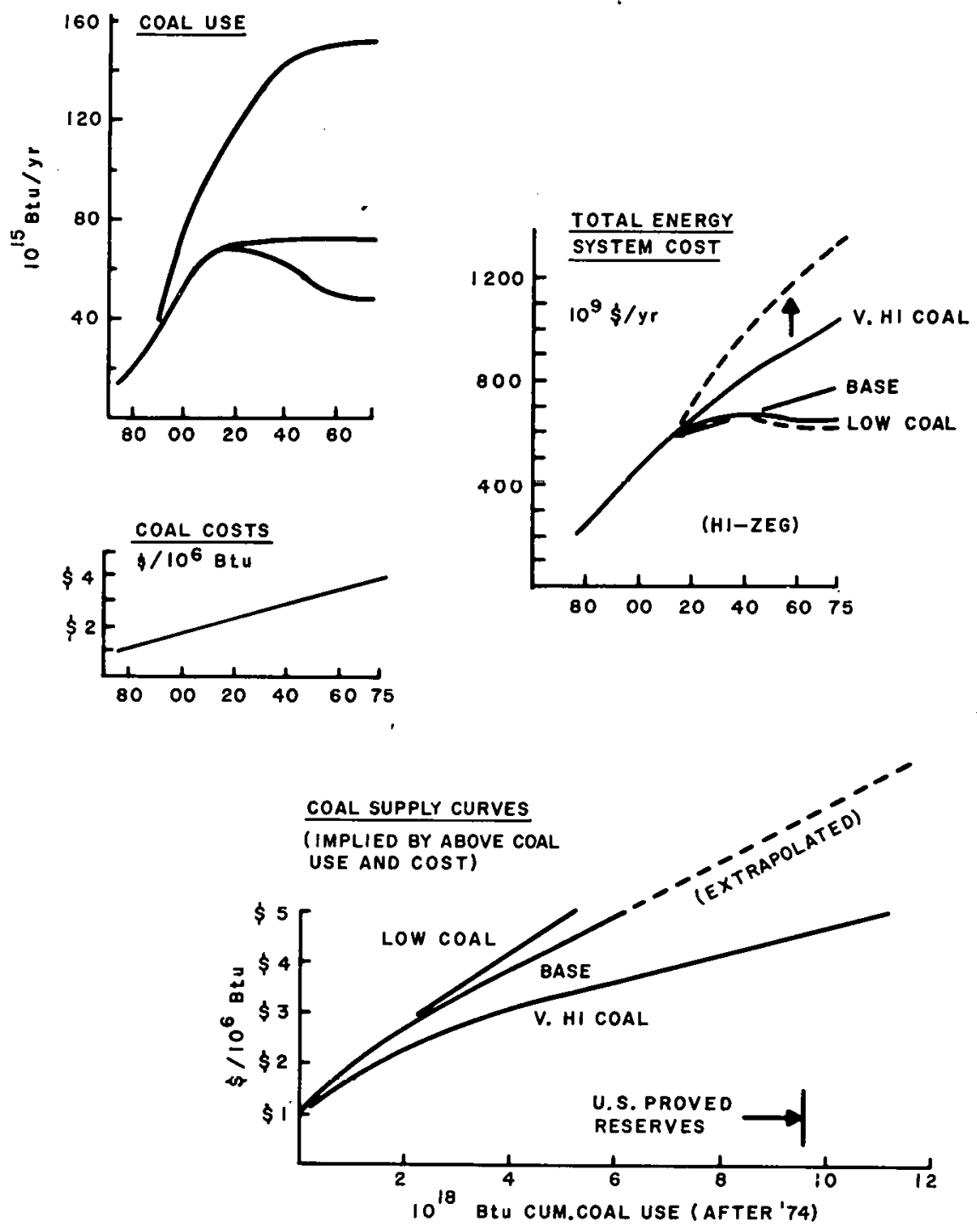

Figure 3-9. Effect on system cost of fixing coal supply curve. 
Figure 3-10 gives the annual system. cost curves for these different fusion capital cost cases. The advantage of a faster learning curve is more pronounced than the effect of a lower initial cost. This is obvious because implementation is very slight in the beginning. The lesson, however, is that very high initial costs can be tolerated on a system wide basis, with widescale implementation to follow only as the ensuing learning curve makes it appropriate. 


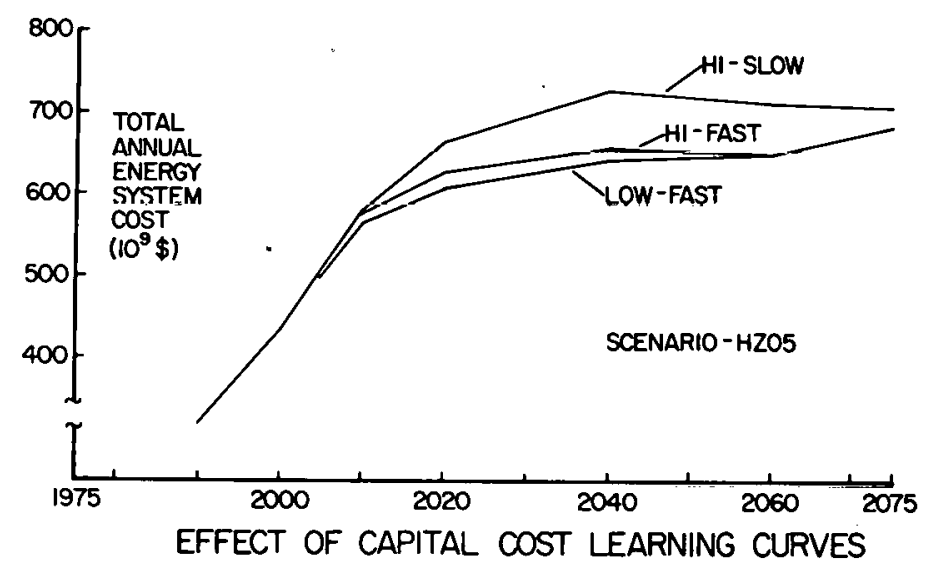

Figure 3-10. Effect of capital cost learning curves. 
1. Sourcebook for Energy Assessment, M. Beller, ed., BNL Report No. 50483 (December 1975).

2. Although the direct integration of the entire cost curve from 1975 to 2075 appears in the computer printout, these are of less interest because resulting 1975 discounted present values are dominated by near-term variations in system cost which are artifacts of the methodology, and not pertinent to the issues in question.

3. $1 \mathrm{mQ}(\mathrm{e})=10^{15} \mathrm{BTU}(\mathrm{e})=33.4 \times 10^{3} \mathrm{MW} \cdot$ years $/ \mathrm{P} . \mathrm{F}$.

For a plant factor of 0.8 , and if each plant is assumed to have a capacity of $1500 \mathrm{MWe}$, then 27.8 plants are required to generate $1 \mathrm{mQ}(\mathrm{e})$.

The thermal requirement is approximately 10 plants per $\mathrm{mQ}(\mathrm{t})$.

4. Work in progress at the National Center for the Analysis of Energy Systems, Brookhaven National Laboratory, for Planning and Analysis/ERDA. 


\section{Chapter 4}

PROJECTIONS OF TOTAL ENERGY CONSUMPTION

The long-term pattern of energy consumption will be singularly important in determining whether or not fusion will be necessary. Unfortunately, however, we cannot predict the future. Nor can the complex interdependence of many factors, such as supply, prices, and consumption be adequately taken into account, except in an ad hoc manner. (There is feedback in the real world which is difficult to model and incorporate into anlaysis.) For example, if the future availability of fusion were assured, we would probably be freer with our use of intermediate resources, and consumption would not be held back as much by supply restructions. Alternatively, increasing resource scarcity over the period presumably would both lower total demand for energy and increase the price that could be paid for fusion reactors. (Note that with respect to fusion implementation, these two forces work in opposite directions.) 
These difficulties of modeling and prediction are circumvented by discussing the future in terms of several scenarios, which are "possible futures" of the energy system and which should effectively bracket the relevant range of possible outcomes. Different methodological approaches are appropriate to the near term (here taken as up to the year 2000) and the long term (75 years Into the 21 st century), since extrapolation rapidly loses validity the further out ones goes from verifiable data.

\section{A. The Twentieth Century}

For the purposes of this study the rest of the twentieth century is called "near term", although in other contexts the year 2000 might be considered mid or long-term. Much can be said in terms of detailed analysis of energy demand and consumption patterns in the near term, but what is of interest here is simply: What will the situation be as the time approaches when fusion might play a meaningful role in the U.S. energy system? How much will energy use grow in the next quarter century? What changes will occur in the pattern of use? Such questions can be answered by specifying demand projections in fairly aggregate terms, appropriate to the level of analysis that can be reasonably undertaken:

Scenario sets to the year 2000 have been generated according to several different criteria. In the BNL Sourcebook ${ }^{1}$ a "future" case was distinguished from a "reference" case by the addition of new technologies and moderate.conservation efforts. An IEA study ${ }^{3}$ bracketed the future with high, medium, and low estimates for demands and supplies in all the individual sectors, as did the Ford Foundation; ${ }^{4}$ with its Historical Growth, Technical Fix, and Zero Energy Growth cases. The FEA ${ }^{5,6}$ distinguished cases according to the price of ofil and policy (Business as Usuál, Conservation, Accelerated Supply, etc.) 
within a monumental modeling effort which attempts to overcome some of the aforementioned problems.

Figure 4-1 shows the totál resource consumption estimated in these various studies. It is important to note the variability among them. In each study totals were arrived at either by projecting ${ }^{7}$ various "macro" quantities as population, GNP, and Energy/GNP (or energy use per capita), or through detailed consideration of each of the energy supply and demand sectors, working from highly disaggregated demand driven models of the U.S. energy system. Beginning. with a population projection (serfes II or III of the U.S. Census Bureau), values are assumed over time for the number of persons/household, for the unit requirements for space heat, water heat, cooking, and miscellaneous electricity (often distinguished geographically and according to housing type). These unit demand figures, along with end-use device efficiency estimates, and particularly changes in them over time, are arrived at by considering current practices, historical trends, current stocks, likely replacement and addition rates, saturation effects, and technological (physical or engineering) 1imits. 8 But there is no rigorous way to establish what values these or any of the other parameters will take on in the future--judgments are made and in many cases different scenarios are set forth to account for different possible trends in fucure energy use practices.

The derivation of residential energy demand is mentioned above. A similar approach is applied to transportation, where population and some set of parameters such as number of vehicles per person, passenger-miles or vehicle-miles, and device efficiency (miles/gallon) are estimated. A slightly different approach must be used for the energy demands for commerce and industry. Here overall business activity levels must be estimated, together with shifts 


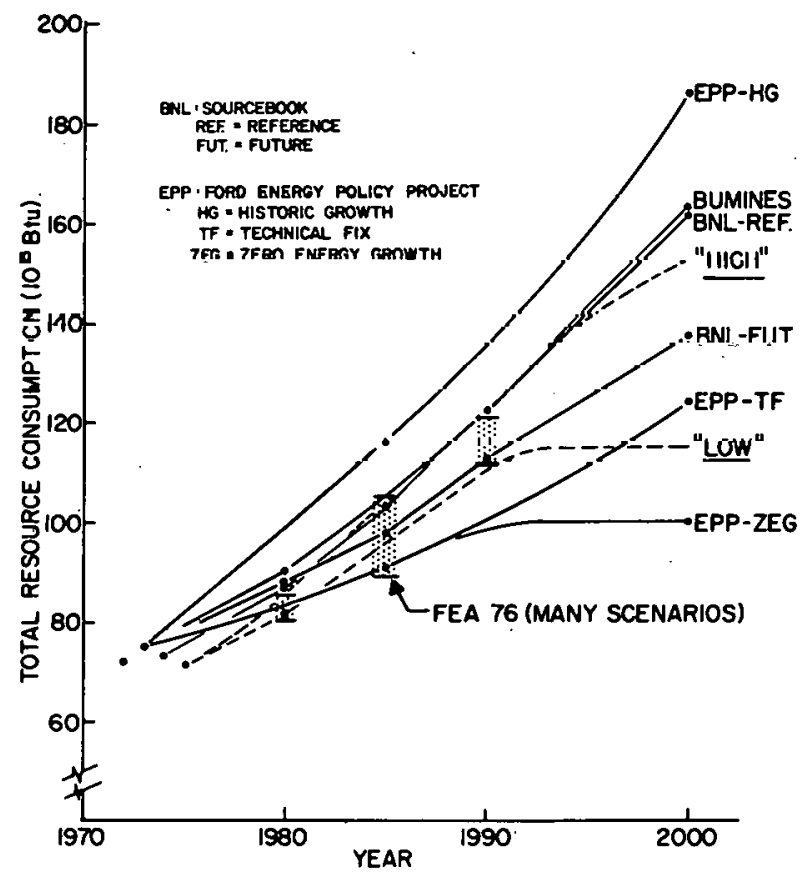

Figure 4-1. Total resource consumption (to 2000). 
which might occur (for example, from metals to plastics, or durables to services). A typical basis might be projected commercial floor space, or tons of steel produced. Again, unit energy requirements must be arrived at--using data for current practice produces a high estimate of future energy consumption if efficiencies are expected to improve in the future due to higher energy costs. ${ }^{9}$ The various studies cited have already scrutinized the various sections of society and the economy, and have chosen methodologies by which to arrive at total energy requirements.

No mention has been made yet of supply, or fuel choices. The "technological" parameters used above reflect assumptions that given fuels are being used in various proportions, in various devices, to meet the demands in given categories. Future practice may permit wide changes in those proportions, as with the generally held view that the U.S. energy system will become increasingly electrified. It is not sufficient then, to report predictions for demands by sectors alone (i.e., Residential and Commercial, Transportation, and Industry), but the fuels in use must also be specified (i.e., electricity, coal, liquids, gasses).

An important problem is the uncertainty in numerical values assigned both to the disaggregated inputs and to the resulting totals. These numbers can only be taken as "givens", for the purpose of performing "if ... then" kinds of analyses. It is, therefore, legitimate for the purposes of this study to use the aggregate figures resulting from detailed analysis done elsewhere, presuming that they represent a reasonable representation of possible futures, while being aware of assumptions in them which may be arguable. Moreover, it is also appropriate to modify with appropriate caution, the aggregate figures as desired so as to describe a different possible future. No unrealism should result so long as a sense is maintained of what such new aggregate figures would imply on the level of a disaggregated analysis. 
The Sourcebook Reference Energy cases project an average annual growth rate in total resource usage of about $2.9 \%$ from 1980 to 2000 , with electrical generation growing at $4.9 \%$. The "Future" cases indicate a resource growth rate of $2.2 \%$ with electricity growing at $2.9 \%$ over the same period. Both scenarios involve the same proportional shift to electricity by the year 2000 , but result in a very different total resource use and total electrical consumption by the year 2000. This is summarized in Table 4-1. Table 4-2 summarizes

T $\triangle B L E \quad 4-1$

ELECTRIFICATION TREND3

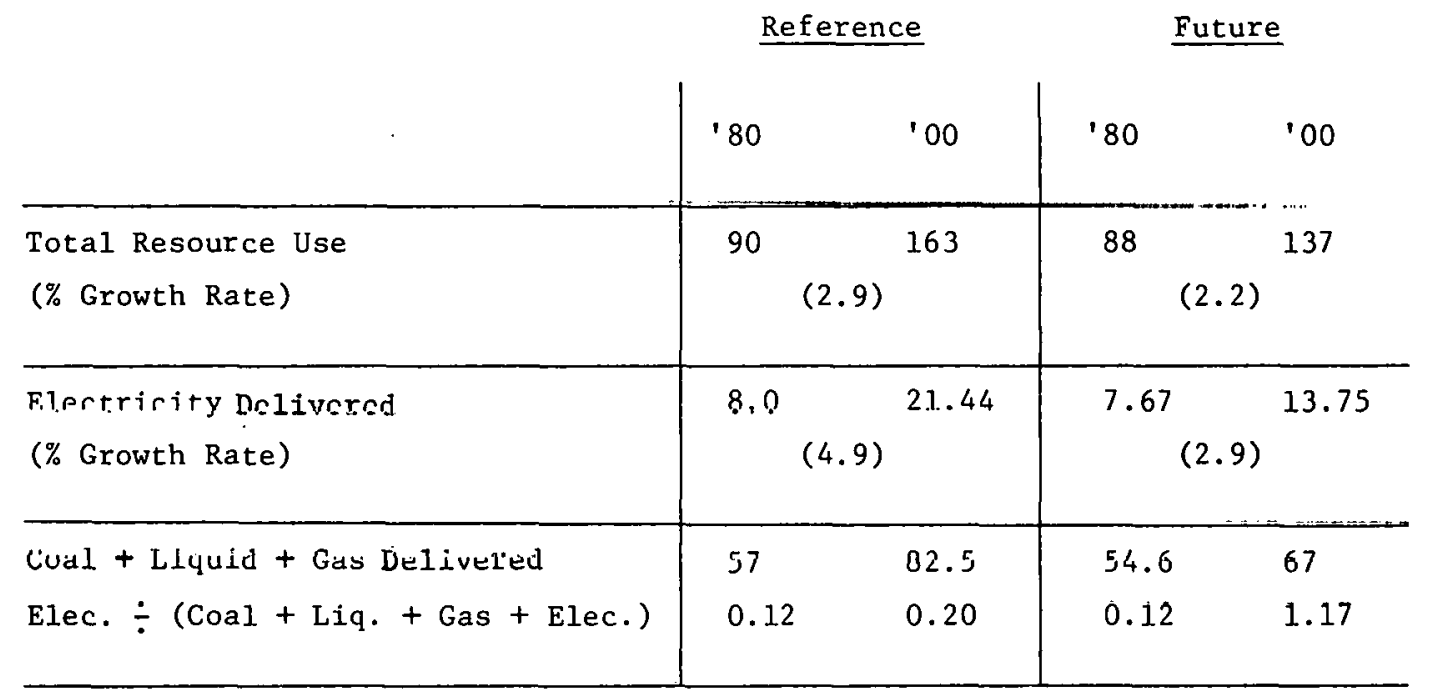

in greater detail the structure of energy supply as projected in the various studies plotted in Figure 4-1.

Two eccnarios, "HIGH" and "LOW", were established for use in this study. For the HIGH case the Sourcebook "Reference" case total consumption figures were taken as representative of most of the higher current projections of energy use. However, the final demand proportions (i.e., among the different sectors) and the carrier mix were adjusted according to the "Future" case. 
T'ABLLE: 4-2

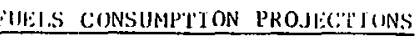

$10^{15}$ B'tl(t) Delivered (Electricisy in btu(e) )
current
1980
1985
1990
2000

$\frac{\text { SOURCEBOOK }}{\text { REFERENCE CASE }}^{\mathrm{a}}$

-Tot. Resources

for $(L \& G$

elec Coa

gen

direct $L \& G$

use $\left\{\begin{array}{l}\text { LdG } \\ \text { Coa }\end{array}\right.$

Fuels*

$\begin{array}{cc}(172) & \\ 8.0^{72} & 9.90 \\ 8.2 & 7.0^{-4} \\ - & 5.4 \\ 43.6^{5.7} & 52.1 \\ 4.0 & 5.0 \\ 48 & 57\end{array}$
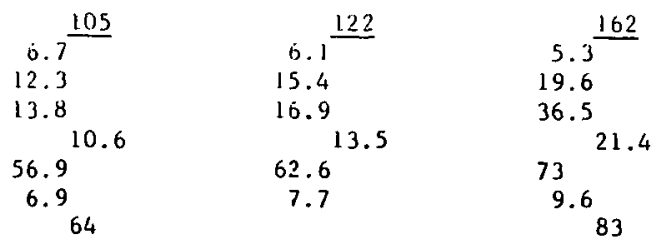

FUTURE CASE

rot. Resources For $(L \& G$

elec $\left\{\begin{array}{c}\text { Coa } \\ \text { guc }\end{array}\right.$

Tot. Electric

direct $\{\& G$

use lCoal

-Fuels

- Tot. Resources

$\$ 13$ REFERENCE CASE

-Tot. Resources

for $\left\{\begin{array}{l}L \& G \\ \text { elec }\end{array}\right.$

ge- $\{$ Nuc

Tot. Electric

direct $L \& G$

use Coal

-Fuels*

FORD ENERGY POLICY PROJECT ${ }^{c}$

HISTORIC GROWTH

-Tot. Resources

Electricity

TECHNICAL FIX

-Tot. Resources Electricity Fuels

ZERO ENERGY CROWTH

-Tot. Resources

Electricity

Fuels

BUMINES $^{d}$

-Tot. Resources

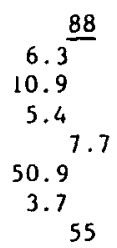

$5.8^{98}$
9.5
13.2
49.9
$49.8^{9}$
5.7
55

$4.3^{113}$
12.2
10.7
51.8
9.0
61

$1.9^{137}$
8.4
24.3
$2^{13.8}$
$11.4^{13.8}$

$\begin{array}{r}(74) \\ 73 \\ \hline\end{array}$

$\frac{80-85}{9}$
$6.6^{82}$
$11.4^{-1}$
3.1
$51.7^{7.8}$
4.2
56

$\frac{91-105}{98}$
$5.8^{\underline{98}}$
15.4
8.7
$60{ }^{5.1} 10.3$
65

$\underline{113}-\underline{121}$

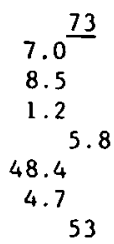

$5.9^{114}$
19.6
13.3
$67^{13.2}$
$5.3 \quad 73$

(none)
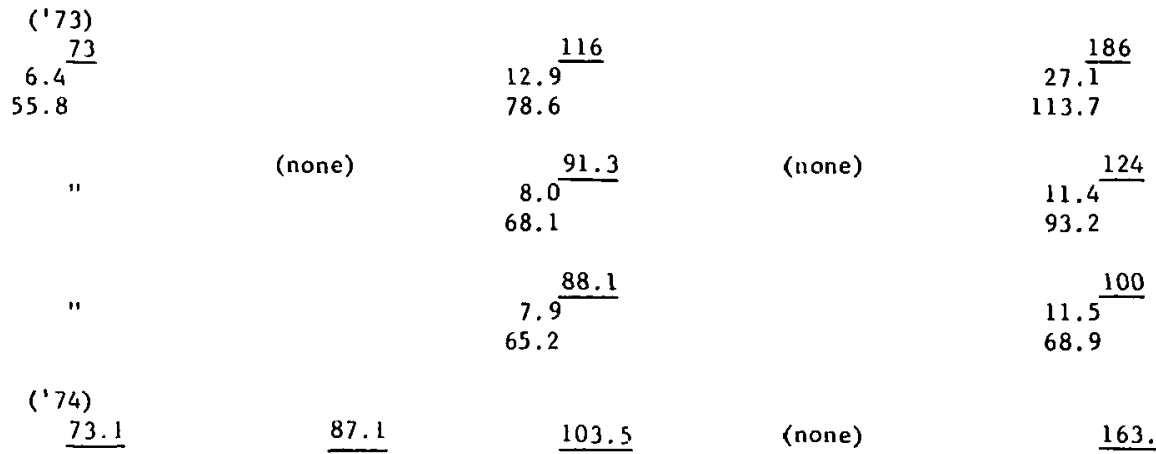

73.1

$\underline{87.1}$

$\underline{103.5}$

(none)

$\underline{163.4}$

a - ref 1 c - rei

b- ref 6 d- ref 7

*Total Coul, Liquids \& Gases used directly (not for elec. gen) 
The LOW case was defined following 8 to $10 \%$ below the Sourcebook "Future" scenario, but leveling off in the last decade at about 115 Quad, in a fashion similar to the Ford Foundation ZEG scenario but not at quite so drastically low a level. Until 1990 then, this LOW case will fall within the lower FEA projections. The demand proportions and carrier mix will again be similar to the Sourcebook Future case. Table 4-3 summarizes the LOW and HIGH 20th century energy scenarios which result in two alternative starting points for the next century, when fusion could begin to play a significant role.

Some examination of such figures reveals an important (and somewhat alarming) fact. It is a matter of "ands", not "ors", to provide energy in the quantities suggested through the course of the next 25 years. The "HIGH" scenario (which isn't very high compared with projections put forth a few years ago) calls for a huge increase in coal production, and a vigorous nuclear program, and continued high ofl and gas imports, and aggressive implementation of coal synfuels. There are no "ors"--all are needed. And this aspect is only slightly less troubling in the case of the "LOW" scenario.

The picture of lite in the U.S., with regard to energy demand, is projected in the HIGH case on the assumption that current consumption patterns continue, with no significant improvement in residential, commercial, or industrial end-use. However, it is assumed that a $40 \%$ improvement in automobile efficiency will be realized by 1980 , because of a shift to smaller cars. It is basically a "no new initiatives" scenario, using census projections for population and housing mix; 4 to $5 \%$ growth rates in industrial activities, and some modest recognition of saturation and leveling effects in the latter part of the next quarter century. The LOW case on the other hand follows the philosophy behind EPP's technical fix scenatio out to 1990. A level of energy consumption is set 
TABLE $4-3$

FUELS CONSUMPTION PROJECTIONS

(this study - approximate supply mix)

$\begin{array}{llll}1975 & 1980 & 1985 & 1990\end{array}$

"HIGE". CASE

-Tot. Resources

$$
\text { for }(L \& G
$$

elec $\{\mathrm{Coa}\}$

gen Nuc

Tot. Electric

direct $\int L \& G$

use Coal

-Fue1s

\begin{tabular}{rrrrr} 
& 71 & \multicolumn{2}{c}{86} \\
8.5 & & 7.0 & \\
8.2 & & 13.0 & \\
1.6 & & 5.3 & \\
& 6.5 & & 8.5 \\
41.6 & & 46.4 & \\
4.5 & & 5.0 & \\
& 46 & & & 51
\end{tabular}

$\begin{array}{rl}6.7 & 105 \\ 14.9 & \\ 11.3 & \\ 55.2 & 11.3 \\ 6.7 & \\ & \\ & 62\end{array}$

$\begin{array}{rl}5.8 & 123 \\ 17.1 & \\ 22.8 & \\ 57.3 & 14.1 \\ 8.9 & \\ & 66\end{array}$

$\begin{aligned} 5.3 & \underline{152} \\ 19.1 & \\ 25.8 & \\ & 19.8 \\ 68.5 & \\ 12.0 & \\ & 80\end{aligned}$

"LOW" CASE

- Tot. Resources

Eor (i\&G

elec $\mathrm{Coa}$

gen Nuc

-Tot. Eiectric

direct $\{\& G$

use Coal

-Fuels

$\underline{71}$

$\begin{array}{rr} & 81 \\ 6.6 & \\ 12.3 & \\ 5.0 & \\ & 8.0 \\ 43.9 & \\ 4.7 & \end{array}$

49

$\begin{aligned} & 95 \\ 13.0 & \\ 10.1 & \\ & 10.1 \\ 49.5 & \\ 6.0 & \\ & 56\end{aligned}$

$\begin{array}{rr}5.2 & \underline{110} \\ 15.3 & \\ 20.4 & \\ & 12.6 \\ 51.3 & \\ 8.0 & \\ & 59\end{array}$

$\begin{array}{rr}4.0 & 115 \\ 14.5 & \\ 19.6 & \\ & 15.0\end{array}$

51.9

9.161 
which provides essentially the same level and quality of services, but which assumes the adoption of specific energy saving technologies, most obviously through the elimination of waste. In the last decade the scenario changes to incorporate the idea of a zero rate of growth--energy consumption reaches a constant level which can sustain a satisfactory economy and society through technological and social change. A lowered standard of living may be implied by ZEG, however, if the gains made on the utilization end are wiped out by increased energy costs of extracting more dilute and inaccessible resources. B. The Twenty-first Century

In the discussion of twentleth century energy consumption projections, the obvious impossibility of prediction was stressed. In its place scenarios were defined to bracket the potentialities of various possible trends, as constrained by the starting point which is established by current reality. In considering the twenty-first century, there is less to go on then in the near or mid-term, and characterizations of lifestyle, population, technology, and society must be parametric, not predictive. Alternative views of the future range from the wildest technological optimism of sclence ficrion, to faith that "good old-fashioned" téchnological and economlc progress will cun= tinue to improve man's condition, to the grim pessimism of some social commentators ${ }^{10}$, to "paradigm shifted" outlooks, ${ }^{11}$ where human values gain center stage and smaller "human"scale technology ${ }^{12}$ replaces megalithic devices and institutions. In considering the implications of fusion, these aspects deserve considerable attention. However, in this study a more modest objective is approached more quantitiatively, insofar as it is possible. 
To establish the necessary framework in which to evaluate the impact of fusion, energy consumption patterns in the 21st century must be posited, but there is no "real" way to determine them. One can, however, set them forth somewhat arbitrarily, with the help of certain available guideposts.

Population is a key parameter. The U.S. Bureau of the Census ${ }^{13}$ projects several series for the structure and size of the U.S. population. These are shown in Figure 4-2. Except for series-I, the widely acknowledged viewpoint is well represented here that eventually population must level off, even if gradually. By looking at various possible values for energy use per capita, some feeling can be gotten for the magnitudes involved in the long-term future of energy. Table 4-4 offers some perspective on this. Data for World and U.S. population per capita energy consumption, and total energy consumption are given under varying sets of assumption.

Currently, the U.S. per capita energy use is $345 \mathrm{MMBTU} / \mathrm{capita}$, far exceeding the world level of $63 \mathrm{MMBTU} /$ capita (MMBTU $=10^{6} \mathrm{BTU}$ ).

Note that U.S. projections for the year 2000 show nearly a doubling of the per capita energy use. And further, the LOW year 2000 energy use of 115 Quad. could maintain the U.S. Census Bureau II-X (no population growth) series year 2080 population of $270 \times 10^{6}$ people with only a modest reduction in per capita consumption.

The world figures given are those of $\mathrm{H}$. Kahn who presents them as to optimistic view of the world over the next 200 years, $^{14}$. where the standard of living throughout the world is foreseen reaching present western standards with the advanced nations maintaining a per capita GNP (and energy use) of from 3. to 5 times that of the world average. Much higher estimates are shown in 


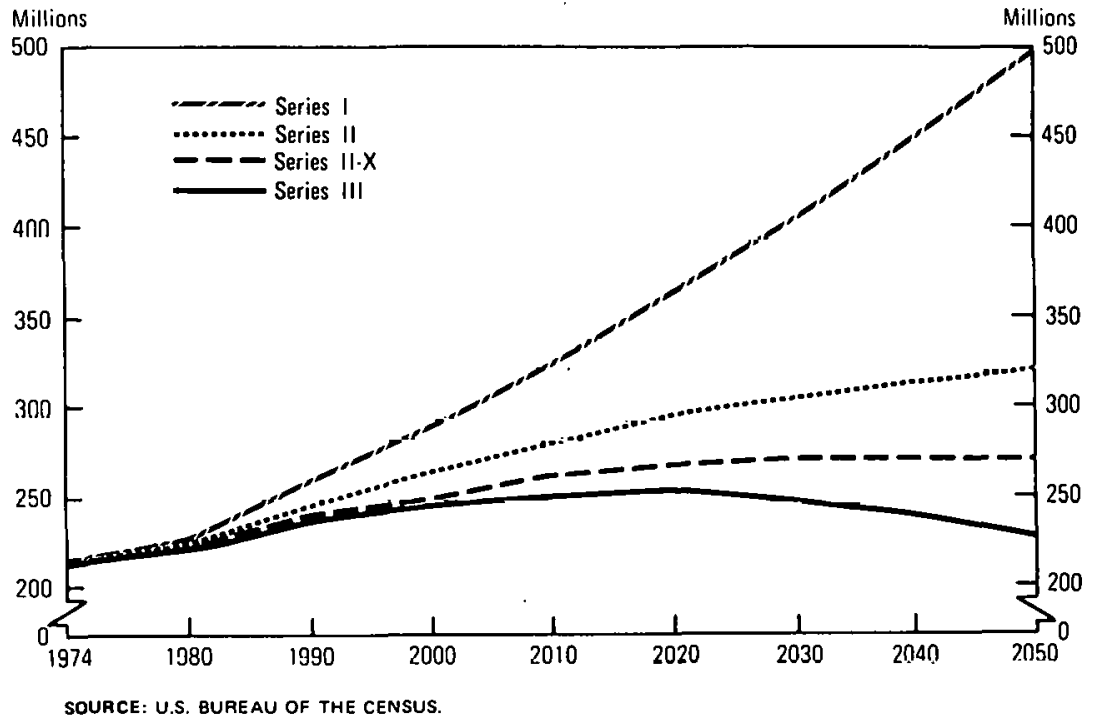

SOURCE: U.S. BUREAU OF THE CENSUS.

Figure 4-2. United States population - Projections to 2050 . 
TABLE $\quad 4-4$

FUTURE U.S. AND WORLD POPULATION AND ENERGY USE

U.S. 1974

Population
$\left(10^{6}\right)$

World ${ }^{\mathrm{a}}$

1975

2075

2175

"20-20" Scenario"

U.S. 2000

Sourcebook, Fut. \& Ref.

U.S. Census II-X, \& II

"LOW" - this study

U.S. $\frac{2050}{\text { U.S. }}$

Census II-X

"

U.S. Census I
212

Per Capita

Energy Use

(106 BTU/Cap.)

(345)

(240)

600

Total

Energy (1015 BTU)

\section{1}

$$
\begin{array}{r}
4,000 \\
14,600 \\
15,000 \\
20,000
\end{array}
$$

250

2,400

3,600

$(12,000)$

$\{137-163$

115
270

$240 \mathrm{p}$

$345 \mathrm{p}$

$500 \mathrm{p}$

(426)

500
(65)

(135)

115

$(300)$

a Reference 14.

b 20 billion pcoplc, $20 \mathrm{kw} /$ pcrion, reference 15.

() Parentheses indicate a derived value.

p Indicates that the value of the parameter was assumed. other entries from references. 
the "20-20" scenario, where 20 billion people all reach a high per capita consumption of $20 \mathrm{kw} /$ person--nearly twice current U.S. levels. ${ }^{15}$

To provide the necessary contexts for this analysis, a twenty-first century LOW case is defined as having constant annual U.S. energy consumption, following the philosophy of the twentieth century LOW case of zero energy growth. If a modest increase to population is projected, it is assumed to be supported in an ever improving standard of living through more efficient use of a constant energy budget.

Over the last seyeral years, the downward trend in long-range energy projections is unmistakable. No longer need anyone discuss the consequences of some everlasting percentage growth rate, as the lessons of exponentlal mathematics are gradually absorbed, and the scale and nature of the problems percelved.

To establish an upper bound to the possible long-range future of energy use, a twenty-first century HIGH growth case is defined according to the premises (1) that very real difficulties can be foreseen for supplying energy at high growth rates in the next twenty or thirty years, and (2) that a later renewed upturn in the rate of increase of energy use could only result from the use of new technologies which cannot be expected to provide substantial quantities in the near to mid terms (namely, solar and fusion). Coupling this to the two 20 th century cases then results in plateaus of constant energy use until the introduction of these. advanced technologies. The detailed shape of these time trends will vary according to the dates and rate of introduction of fusion (or solar).

A limit is set at $\sim 300$ Quad./yr, as the highest total resource use allowed in any scenario through the year 2075.

Figure 4-3 summarizes the overall time trends of annual energy consumption established for this study. 


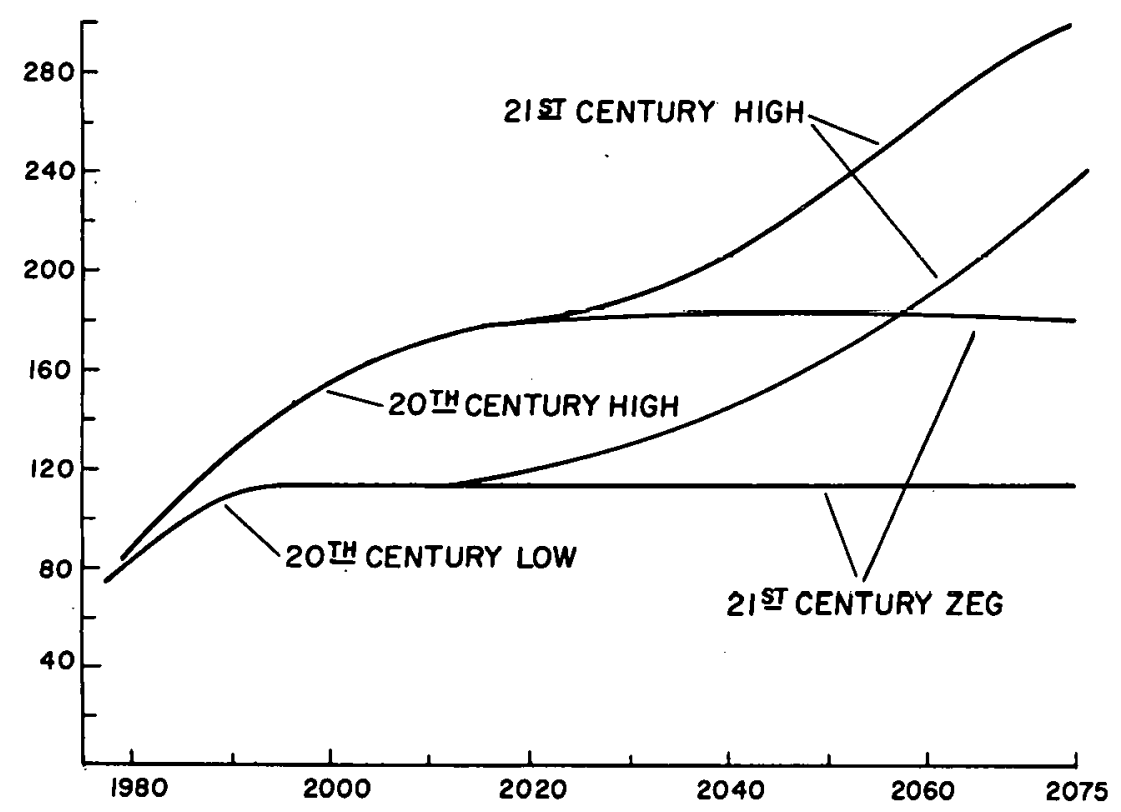

Figure 4-3. Annual resource consumption $10^{15} \mathrm{Btu} / \mathrm{Year}$. 
1. Sourcebook for Energy Assessment, B. Beller, ed., BNL Report 50483, December, 1975. Projections in the Sourcebook are essentially the same as scenarios 0 to $V$ in ERDA-48 (Ref. 2).

2. A National Plan for Energy Rd \& D, ERDA-48, June, 1975.

3. "The IEA Energy Simulation Model; A Framework for Long-Range U.S. Energy Analysis", C. Whittle and D. B. Reister, January, 1975.

4. A Time to Choose, Report of the Ford Foundation Energy Policy Project, Ballinger Publishing Company, 1974.

5. Project Independence Report, Federal Energy Administration, November, 1974.

6. National Energy Outlook, F.E.A., February, 1976.

7. U.S. Energy Through the Year 2000 (Revised), Bureau of Mines, Department of Interior, W. G. Dupree and J. S. Corsentino, December, 1975.

8. Effictent Use of Energy: A Physics Perspective, American Physical Society Study Group, Physics Today, August, 1975. This study argues that the technological limits for conservation measures offer far more opportunity than is currently acknowledged in most analyses.

9. The role of costs play in determining future consumption levels is exceedingly difficult to predict in detail. Historical elasticities can be used*, or as in the Project Independence FEA Demand Model (Ref. 5, Appendix A, Pg. 55) capital equipment investment decisions are assumed to be made according to fuel price changes, with a consequent gradual lagged adjustment in demand. (*See for example "The Effect of Price on Demand for Electric Energy During the Rest of the 20th Century", D. Chapman, A.A.A.S., pg. 68, February, 1975).

10. R. L. Heilbroner, An Inquiry Into the Human Prospect.

11. For example, see Hazel Henderson: "Nudging Society off its Macho Trip", Science, Vol. 190, pg. 862, November, 1975.

12. E. F. Schumacher, Small is Beautiful, Economics as if People Mattered, Harper and Row, 1973.

13. Statistical Abstracts of the United States, 1975, U.S. Department of Commerce, Bureau of the Census.

14. H. Kahn, et. a1., The Next 200 Years, Wm. Morrow and Company, Inc., New York, 1976.

15. P. F. Palmedo, Private Communication. 


\section{Chapter 5}

\section{CONCLUSIONS}

This study was undertaken to explore the potential role fusion might play in the future U.S. energy system, especially as interpreted through cost/benefit analysis, and as it might bear on current R\&D decisions; also to develop perspectives and methodologies for long-range R\&D planning and justification; and to examine cost/benefit analysis for its suitability, limitations, and relevance to fusion.

The potential need for fusion was evaluated by first developing a perspective on what issues can be meaningfully addressed: Questions must first be asked before they can be answered. A methodological framework was needed which sufficiently and appropriately characterized the U.S. energy system. The study 
then proceeded by identifying the key factors that will bear on the need for fusion, identifying the quantitative assumptions about the future of energy which result in a finding that benefits are indeed attributable to fusion, and making explicit the consequences imbedded in those assumptions.

One conclusion that emerges is that cost/benefit analysis, as presently understood and applied, is of questionable applicability to fusion $R \& D$. The extreme sensitivity to assumptions undermines any confidence one might hope to have in quantitative results. Furthermore, the assumptions themselves can be little more than conjecture, because of the time scale involved.

However, that fact does not prevent one from asking: "Very well, I won't. believe the numbers, but tell me how big they are anyhow, if I assume this value for this and that value for that"? In the results of this study not unreasonable scenario comparisons, with and without fusion, indicate that benefits in the form of direct cost savings could in fact exceed $R \& D$ costs (depending on the choice of discount rate); this without an accounting of externalities--the benefits attached to avoiding pollution and proliferation, as well as the benefit of the availability of energy itself.

S1mple ar1thmetic and common sense provide powerful constraints on a11owable or reasonable projections of total future energy use and combinations of supply, but the parameter space nevertheless remains very large. By mapping out parts of that space, some of the factors critical to the need for fusion have been examined. The most important of these are:

1. The future behavior of total energy consumption, and

2. The future availability and cost of alternative suppiies. The study has outlined some of the regions of that space where significant benefits are attributable to fusion. 
Basic trade-offs among resources were studied, and some sensitivity analyses were done on coal cost and fusion capital cost. On a system-wide basis, very high initial fusion plant capital costs can be tolerated, with widescale implementation of fusion to follow only as the ensuing learning curve brings the capital costs down. The cases which indicate the greatest relative benefits of fusion (1.e., the difference between the total system cost of two scenarios with and without fusion) are those involving high reliance on coal and high costs for coal. In these cases the use of fusion to replace a major portion of the coal use results in systems savings which can reach the $\$ 200$ to 500 billion/year mentioned above, out of total annual cost of $\$ 700$ to 1100 billion/ year. For assumptions which lead to lower relative benefits, it must be remembered that only direct costs have been considered. Decisions are more likely to be made on the basis of the less quantifiable externality issues such as health, safety, and the environment. For example, society may make a political (noneconomic) decision against plutonium.

\section{Total Resource Consumption}

In Chapter $I$ any attempt in this study to characterize the benefits of greater or lesser energy consumption per se was specifically disavowed. Without some characterization of the linkage between energy, the economy, and quality of life, however, it is difficult to represent quantitatively the expected benefits of fusion with respect to their variation with future total energy consumption. Certain elements are obvious, however. If more energy is to be consumed, the resource must come from somewhere.

In Figure 5-1 scenarios are presented together--all of which involve the use of fusion and imports, but no breeder. As the total consumption picture increases, there are strong reasons to hesitate presuming that either fission or 

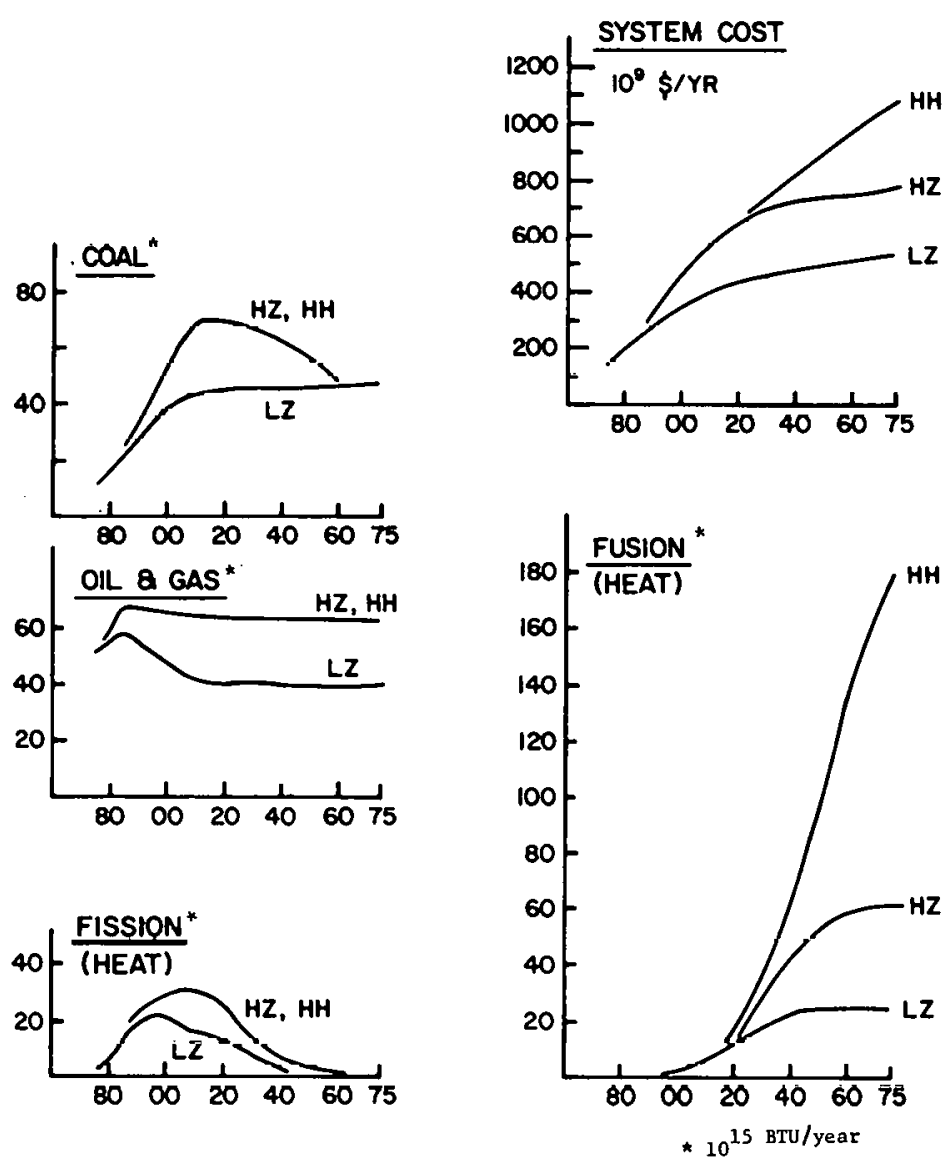

Figure 5-1. Annual system cost \& resource use Total consumption comparisons LZO2 H7.n4 HHO1

Fusion, Imports, no breeder 
the fossil fuels could be extended much beyond the levels shown to meet the total requirement. As seen previously in the discussion of long-range alternatives, there are but three basic choices: fusion, the breeder, or solar.

If high or only moderately high energy use is to be even possible in the next century, the role fusion must play and the urgency of its availability are readily apparent. For the case of lower total consumption, the urgency of fusion may be less compelling. However, its absence would still have to be made up by one of the other resources. In the cases shown, imports have been assumed available--their removal would increase the pressure on alternatives. The potential benefits of a commercial fusion program are enhanced in a world where total demand continues to grow, and/or where alternative resources are limited or costly.

- If imports are restrfcted,

- If coal use cannot rise greatly (because of limitations on production capacity, increasing costs, or environmental effects),

- If fission is not to be greatly expanded, and developed in a form which can make more complete use of the resource,

- If central station solar cannot be made reliable and economic,

- If the choice of discount rate is not too high, and

- If fusion can be available earlier and quickly implemented, regardless of initial cost.

An extreme in any of these factors, or any combination of them to a lesser degree, indicates the necessity and desirability of substantial reliance on fusion energy in the twenty-first century. 
Future work should focus on developing alternative methodologles to facilitate an accounting of the noncommensurable externalities, to deal with the question of present.society's responsibllity for future generations, and to help In the decisions which allocate current $\mathrm{RD} \& \mathrm{D}$ expenditures. For example, the range of energy, supply, demand, and cost projections might be handled with a probabilistic approach, as an advance over the use of deterministic single-valued scenarios whose relative likelihood of occurrence can only be implicitly considered. Uncertainty is a key issue--1t is one of the reasons discounting is used, and at the same time the reason why a more complex treatment is needed. Keeping energy options open involves the expenditure of resources and the bearing of risk, where the possibility of failure must be weighed against the possibility of immense value if not critical necessity. Fusion offers potential access to one of the very few perpetuable energy resources.

\section{Notes to Chapter 5}

1. In the $\mathrm{HH}$ scenarios, the Increase form 150 quads. In 2000 Lu 300 quads in 2075 corresponds to an average annual growth rate of only $\sim 1 \%$. 


\section{APPENDIX A COST/BENEFIT ANALYSIS}

Cost Benefit Analysis is the name given to the set of techniques used to evaluate the desirability of investments, especially projects and programs undertaken by governments in the public interest. It is based on the fundamental premise of "economic efficiency", which asserts that the general social welfare will be maximized when optimal use is made of resources. ${ }^{1}$ Thus the value of outputs of a project should maximally exceed the value of resources used (i.e., diverted from other projects). Projects can be ranked and chosen according to this criterion of greatest net benefit.

Cost/Benefit Analysis is used to make such determinations. Simply stated, it involves the identification of all the impacts of a project, both favorable and unfavorable, and the valuation of these impacts, where possible, in monetary terms. The favorable impacts (benefits or outputs) might be valued according to the amount the gainers of the project are willing to pay, and the unfavorable in terms of the amount of compensation due those who are adversely affected. ${ }^{2}$

Though very straightforward in concept, Benefit/Cost Analysis turns out to be very much more difficult in practice. The foremost difficulty is that of establishing prices for the valuation of costs and benefits. ${ }^{3}$

\section{$\underline{\text { PRICES }}$}

One looks to the private sector (the "free market") to see what prices are being paid there for equivalent commodities or services. This is presumed to be the best available measure of the value attached to them by society. But government programs come into being specifically to fill gaps left by market imperfections, and they also have benefits which are frequently less tangible and may not have equivalents in the free market. There are incommensurables or socially 
valued activities for which price or monetary value simply do not enter in. A "willingness-to-pay" approach to setting values is treacherous and difficult--non-market social interactions may not obey the same logic as market interactions. Pricing is not the only difficulty. There are numerous other complexities in identifying a11 the effects of programs.

Externalities are side-effects for which no compensation can be or is paid to the losers (or paid by the gainers). Pollution and environmental disruption are examples; the polluter is taxed, but there is no way payment can be made to all the individuals who are adversely affected. Secondary Impacts and NonEfficiency Objectives: a project may have no net effect on the economy but may cause, for example, a boom in one place at the expense of surrounding areas. These effects are often ignored despite their potential significance. Also, there is the danger that only one side will be noted, as the gainers (or losers) can be highly localized while the losers (or gainers) are dispersed. The recipients of benefits may not be the ones who incur the costs--a project can have important income redistribution effects whose suitability to social equity goals 15 not easy to assess. Objectivity is hard to maintain when almost everyone has a stake of one kind or another. It is unrealistic to expect an advocate not to emphasize benefits and minimize costs. And this can occur in full sincerity, realizing the difficulty in even identifying all the effects of an undertaking. Present Value: An investment invariably involves incurring costs at one time and realizing benefits at some other time. An investment is made now with the expectation of a return in the future (or the opposite--go now, pay later). The present value of a cost (or benefit) to be..realized at a future time is less by some percentage than a cost (or benefit) right now. Discounting is the term given the 
technique used to collapse a stream of costs and benefits over time to permit them to be compared in terms of their "present value".

$$
P V\left(T_{0}\right)=\sum_{t=T_{0}}^{T} B(t) \frac{1}{(1+R)^{t-T_{0}}}
$$

Equation (1) shows the summation of an annual benefit stream $B(t)$ to calculate its total present value evaluated at time $T_{0}$. If a decision were to be made between receiving a benefit equal to $P V$ now, as against the benefits $B(t)$ spread out over future years, equation (1.) would define the point of indifference between the two choices, once the discount rate $R$ has been defined.

\section{THE DISCOUNT RATE}

The present value is extremely sensitive to the choice of discount rate, making it a crucial and thus highly controversial parameter. The discount rate is usually set equal to the "opportunity cost of capital," which is the rate of return that would be obtained if the resources were invested in the private sector rather than in the project under consideration. It is the "price" of investment capital, and thus shares some of the same valuation difficulties as do the costs and benefits themselves. There are many different rates of return in the economy; ideally then different discount rates should be applied to different parts of a project, depending on which economic sector resources are being diverted from.

\section{$\underline{\text { RISK }}$}

Higher returns are earned by investments when the level of risk is higher. Should "risky" or "riskless" rates be used to discount government projects? Some argue that the higher return, on average, just compensates the investor for his higher proportion of loss, so the lower riskless rate is the real rate 
of return. Others argue that a failed investment only hurts the investor and not society (the equipment and buildings still exist). Therefore, all investments are already riskless from society's point of view and the higher return is real, representing real growth to the economy. This argument remains unresolved in the economics literature.

\section{SOCIAL DISCOUNT RATE}

A distinction is often suggested between the standard investment discount rate, and a "social" discount rate, which it is felt should reflect a broader sejt of issues and values than just economic nnes. However, there is little agreement on what it should be. What follows is a summary of the main arguments frequently heard on the subject. No attempt is made at resolution, but rather to set forth the major points at issue.

FOR LOW DISCOUNT RATES

Arguments for low (even negative) discount rates and against high rates (or discounting itself) emphasize several points:

An Emphasis on the Near-Term results from normal discounting, leading to choices which may be suboptimal from a 1ong-term perspective. ${ }^{4}$ For example, $R \& D$ for advanced technologies has a very long lead time. But choosing short-term solutions instead may lead to serious consequences if inadequate preparation is made for the eventual exhaustion of the resources on which we now depend.

Grandchildren: people constantly forgo current consumption for altruistic or nonernnomic reasons. This is real and commonplace social behaviur that is simply not addressed by discounting methodology, though it may bear considerable relevance to long-term social issues. 
The Transcendence of Values Over Money in part summarizes some of the arguments against discounting and cost/benefit analysis. Some people simply find the setting of prices on social values to be offensive and impertinent, despite the oft-made statement that a choice nevertheless implies a price (the value or price of the next thing one could have done with the resources) through revealed preference. There are incommensurables and social values which perhaps should be handled explicitly, and not incorporated into an economic efficiency framework through the assignment of a price.

FOR HIGH RATES

The arguments for discounting, with rates figures according to the opportunity cost of capital, likewise center around a few main points.

The Economic Efficiency Criterion would be violated by the use of a low rate. Using too low (or high) a rate will reduce the general social welfare by allowing unprofitable projects to be undertaken--absorbing resources which could have been put to better use.

Future Society, from all indications, will be richer and smarter than we are. To what extent should we sacrifice our own well-being for their comfort or convenience? Conversely, that future bounty may in fact depend on present investments. But how many of the very pressing needs around the world today do we put off so as to prepare for future generations? The whole question of intergenerational responsibility is immensely hard to deal with.

of Uncertalnty we can be certain. Circumstances will change and prognostications may or may not he proven accurate. If in 1876 the U.S. had projected the future demand for whale oil through the year 1900, huge government investments in whales might have been made. Obviously such efforts would have been unnecessary, and would have diverted funds from other more productive uses. One can only wonder what unexpected developments await us. 


\section{Conclusion}

Is a given project worthy of public funds? To the extent that it is appropriate to evaluate a project in terms of its readily enumerable inputs and outputs and its desirability as a monetary investment, cost-benefit analysis and discounting provide the information for that assessment. However, the methodology is not without 1 imitations, complexities, and controversies. Hopefully, future theoretical work will augment and expand the relevance and applicability of cost-benefit analysis; in the meantime its conclusions must be careful. y relegated to their appropriate place in the making of decisions.

\section{FOOTNOTES}

1. It might be noted that this philosophical premise, and its modern economic interpretation, are not universally agreed upon.

2. When the benefits cannot be evaluated, but are acknowledged as a "public good" (i.e., defense, space, etc.), then cost effectiveness is invoked. The objective is to be accomplished in the most economical manner possible.

3. Th1s controversy, as well as many of the other points raised here, are discưssed in mnre detail in Public Expendicures d Yolicy Analysis, ed. R. H. Haveman, Markham Publishing Company, 1970.

4. Hopefully, the present value would not be used as a ranking criterion, without considering the more detailed behavior over time of the cost and benefit streams, A preference based solely on the rclative magnitude of present values might not be the choice that would be made were the 1arger picture examined. A course of action with near-term payoff is inevitably preferred on a present value basis even if its long-term consequences are disastrous. 


\section{APPENDIX B MINIMUM LONG -RANGE NET BENEFITS}

With a few simplifying assumptions, it is possible to calculate easily the present value in 1975 of a given net benefit stream that might result from the Introduction of an advanced technology during the next century.

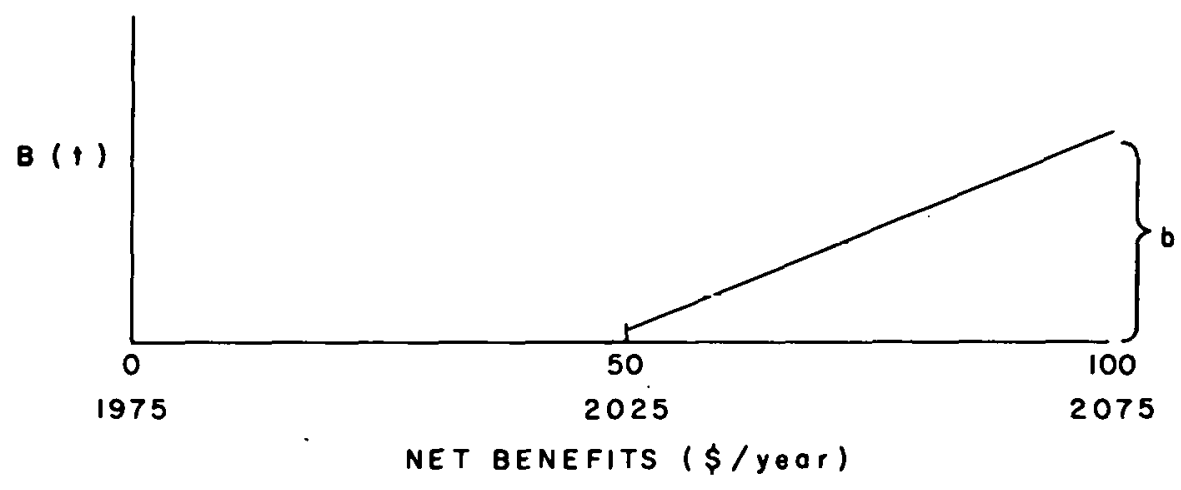

Figure B-1. Net benefit stream.

The essential elements are represented in Figure B-1 where the net benefit stream is shown as beginning 50 years from now, in 2025, and increasing 1inearly through 2075. This "wedge" would correspond to the savings, or difference In overall energy system cost, that might result from fuston. The use of a linear function allows direct calculation of discounted present values while approximating the curve likely to result from a more detailed treatment where quantitative cotimatco for cncrgy quantitics and costs are used. The parameter $b$, the net annual savings in 2075, can be varied to test different magnitudes of savings.

$$
P V\left(T_{0}\right)=\sum_{t=T_{0}}^{T} B(t) \frac{1}{(1+R)^{t-T_{0}}}
$$


Equation (1) gives the general formula for calculating the present value of the annual benefit stream $B(t)$.

In integral form; this can be written

$$
\begin{gathered}
\operatorname{PV}\left(T_{0}\right)=\int_{T_{0}}^{T} B(t) e^{-\alpha\left(t-T_{0}\right)} d t \\
\text { where } \alpha=\ln (1+R)
\end{gathered}
$$

Applying this to the curve in Figure (B-1)

$$
\begin{aligned}
\operatorname{PV}(1975) & =e^{-50 \alpha} \mathrm{PV}(2025) \\
& =\mathrm{e}^{-50 \alpha} \int_{0}^{50} \frac{\mathrm{b}}{50} \mathrm{t} \cdot \mathrm{e}^{-\alpha t} \mathrm{dt}
\end{aligned}
$$

This integral is easily done:

$$
\int_{0}^{T} t e^{-\alpha t} d t=\frac{1}{\alpha^{2}}\left[1-e^{-\alpha t}(1+\alpha T)\right]
$$

Therefore:

$$
\begin{aligned}
& \operatorname{PV}(2025)=\frac{b}{50} \cdot \frac{1}{\alpha^{2}}\left[1-e^{-50 \alpha}(1+50 \alpha)\right] \\
& \frac{P V(2025)}{b}=\frac{50}{A^{2}}\left[1-e^{-A}(1+A)\right] \\
& \text { where A }=50 \alpha
\end{aligned}
$$


RESULTS FOR DIFFEREIT DISCOUNT RATES

\begin{tabular}{|c|c|c|c|c|c|c|}
\hline$R(z)$ & $\alpha$ & A & $e^{-A}$ & $\frac{\mathrm{PV}(2025)}{\mathrm{b}}$ & $\frac{\mathrm{PV}(1975)}{b}$ & $\begin{array}{c}b\left(10^{9} \$\right), \text { for } \\
\text { PV }(1975)=\$ 10 \times 10^{9}\end{array}$ \\
\hline 1 & 0.0995 & .498 & .608 & 18.0 & 10.94 & 0.9 \\
\hline 3 & 0.0296 & 1.48 & .228 & 9.92 & 2.26 & 4.4 \\
\hline 5 & 0.0488 & 2.44 & .087 & 5.88 & 0.51 & 20 \\
\hline 7 & 0.0677 & 3.38 & .034 & 3.7 & 0.12 & 83 \\
\hline 9 & 0.0862 & 4.31 & .013 & 2.5 & 0.03 & 330 \\
\hline 10 & 0.0953 & 4.77 & .0085 & 2.1 & 0.018 & 550 \\
\hline 15 & 0.140 & 6.99 & .00092 & 1.02 & 0.0009 & 11,000 \\
\hline
\end{tabular}

Table B-1 gives results from equation (3) for different discount rates $R$. The minimum 2075 annual savings b which results in a $\$ 10$ billion present value In 1975 is shown in the last column. Two aspects are noteworthy-these figures are not so large, and secondly they are extremely sensitive to the discount rate. Savings of $\$ 300$ to $500 \mathrm{billion/yr}$ are on the order indicated in the fusion scenarios as compared with high coal scenarios (see Chapter 3.) (These savings, moreover, reflected only actual production costs and none of the numerous externalitles that will be attributable to high coal usage.) 


\section{THIS PAGE WAS INTENTIONALLY LEFT BLANK}




\section{APPENDIX C TIME PHASED REFERENCE ENERGY SYSTEM GENERATOR*}

TPRESG is an interactive computer program written for; use on the INTERCOM system of the Brookhaven National Laboratory Central Scientific Computing Facility. It is based on the Reference Energy System methodology, a diagramatic description of energy flows in the U.S. energy system, with the addition of explicit incorporation of the time dimension.

The purpose of TPRESG is to provide a convenient framework in which to specify quantitatively the flows in the U.S. energy system over time (the next 100 years) in such a way that each energy activity variable varies smoothly and reasonably over time, while bearing a consistent relationship to the other energy flows at each point in time. Then, once a given scenario is defined, several of its attributes and implications are readily calculated and output in a convenient format.

\section{Basic Structure}

Figure $C-1$ shows the simplified reference energy system. Data values appearing on the various links are annual total energy flows for the U.S. energy system in 1975. Efficiencies are indicated where a conversion or distribution process entails some loss of energy. Figure C-2 shows the diagram again but with "act.tvity" indexes indicated. Each energy activity has been assigned an index number (i.e., total distributed electricity is activity $\#^{20,}$ total coal mined is \#11, electricity generated by coal steam is \#9). The activities in heavy circles are those whose values are printed in the final output. (see Figure (-5)

\section{Initial Data Set}

A complete, consistent set of data must be specified to initialize TPRESG. This consists of values for each of 10 reference years. This initial data set

‡ A newer version has since been written called PRESTO, based on the same ideas hut with constderably expanded capabilities. Ite operational details are also quite different. 


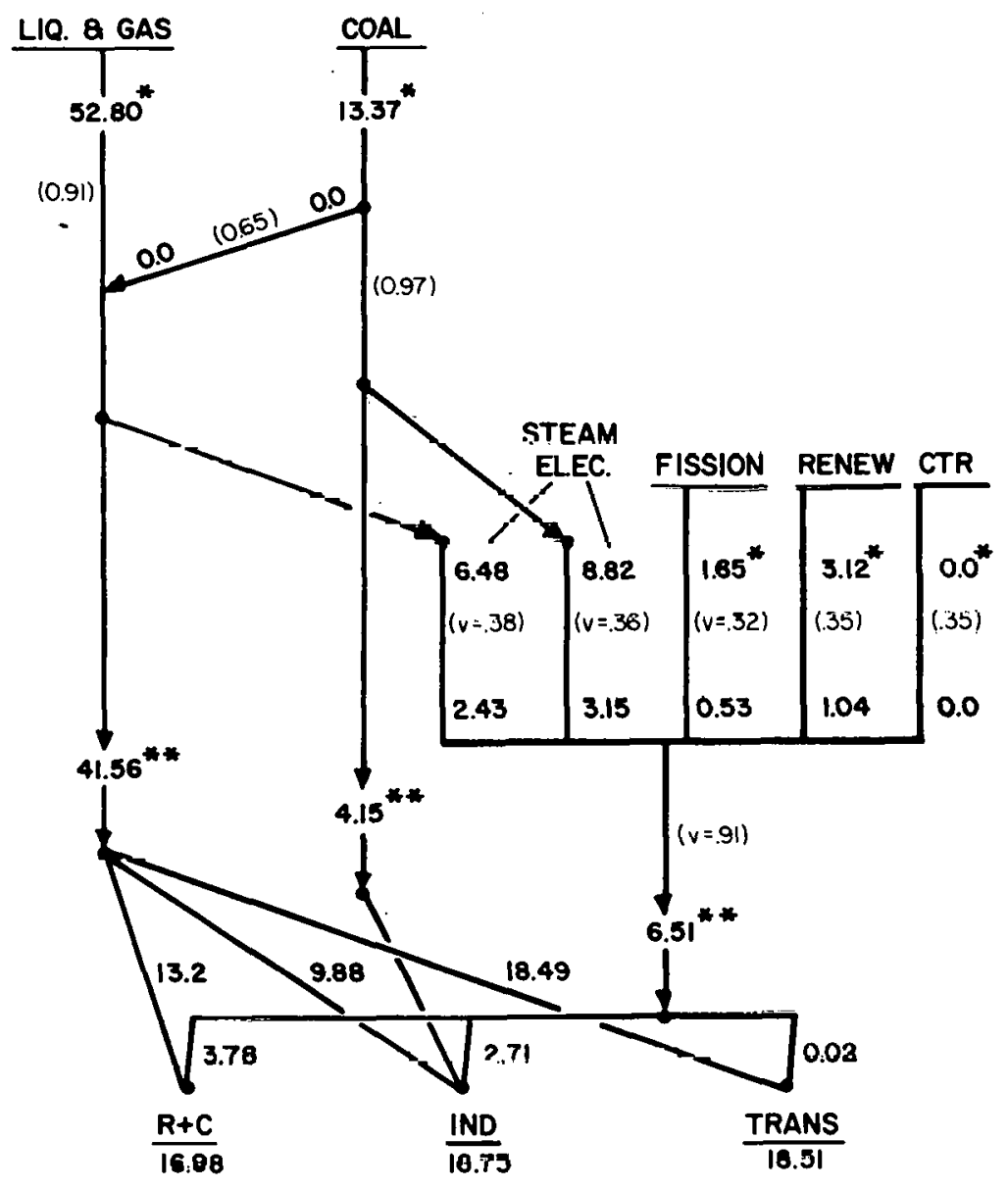

total RESOURCE U3E • BUM OF* VALUES TOTAL USE $=$ SUM OF FUELS**

( ) PARENTHESES INDICATE CONVERSION EFFICIENCIES $v=$ VARIABLE EFFICIENCY

Figure C-1. Reforence encrgy system $T$ P R $R, 3 G$ (1975 data)

(1015 Btu/Year) 


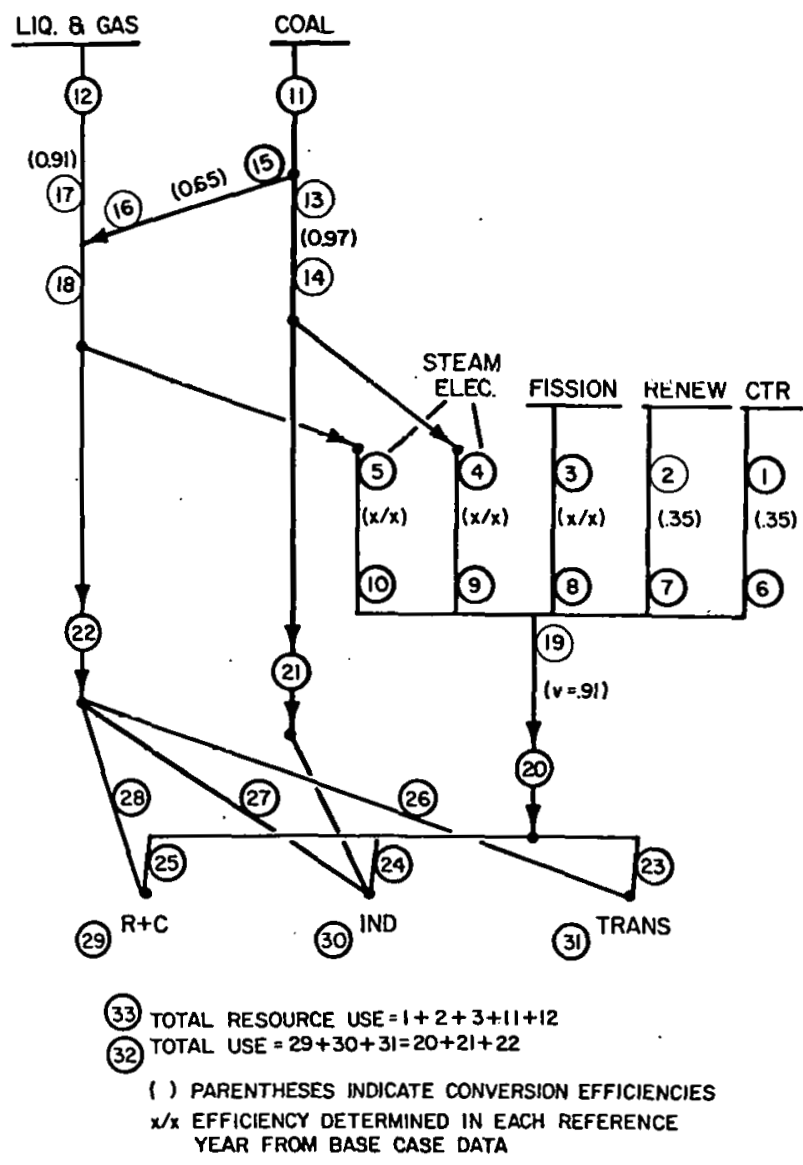

Figure C-2. Reference energy system T P $\dot{R}$ E S G Energy flow activity variable indexes. 
must already exhibit self-consistency in each. reference year. For example:

$$
x_{14}=x_{4}+x_{21}
$$

and

$$
x_{19}=x_{6}+x_{7}+x_{8}+x_{9}+x_{10}
$$

Table C-1 shows the base case specification (HZ01) developed for the HIGH-ZEG cases. Once this initial data set is established, a series of interactive commands enable the user to make changes in the energy totals.

\section{Activity Level Changes}

Activity level changes are specified in the format:

IACT1, IYEAR, AMT, IACT2

where - IYEAR must be one of the 10 reference years

- AMT is a floating point number specifying a change to be made (in Quads)

- IACTI

- IACT2

are activity variable indexes

When only IACI' is entered (enter IACT2 = 0) the amount AMT 1o added to variable \# IACT1 for the year IYEAR. If a value for IACT2 is entered then the amount AM' is deducted from variable \# IACT1 and added to variable \# IACT2. In other words, that amount is transferred from IACT1 to IACT2.

When any change is made that affects adjoining variables, corrected values are computed for those variables so that consistency of the flow network is maintained in that reference year. For example, a change in one of the electrical generation modes (IACT1 $=6-10$ ) with IACT2 $=0$ will result in a change in the total electric generation--so variables $\# 19,20$, and $\# 23,24$, and 25 are recomputed. (The final demand changes are allocated in proportion to the already 
TABLE C-1

BASE CASE DATA SET

\begin{tabular}{|c|c|c|c|c|c|c|c|c|c|c|c|}
\hline & & 1975 & 1980 & 1985 & $19 \frac{\text { REF }}{990}$ & $\frac{\text { RENCE }}{200 G}$ & $\frac{\text { YEAR }}{2010}$ & 2020 & 2040 & 2060 & 2075 \\
\hline & 1 & $\frac{1.00}{0.00}$ & 0.00 & 0.00 & 0.00 & 0.00 & 0.00 & 0.00 & 0.00 & 0.00 & 0.00 \\
\hline & 2 & 3.12 & 3.14 & 3.63 & 5.14 & 7.20 & 8.60 & 9.14 & 9.14 & 9.14 & 9.14 \\
\hline & 3 & 1.65 & 5.3 .4 & 11.33 & 23.97 & 28.86 & 33.80 & 35.80 & 36.80 & 36.80 & 36.80 \\
\hline & 4 & 8.82 & 13.03 & 14.86 & 18.00 & 19.14 & 20.90 & 22.00 & 22.90 & 22.90 & 22.90 \\
\hline & 5 & 6.48 & 6.98 & 6.70 & 6.15 & 5.30 & 5.00 & 4.71 & 4.36 & 4.36 & \\
\hline & 6 & 0.00 & 0.00 & 0.00 & 0.00 & 0.00 & 0.00 & 0.00 & 0.00 & 0.00 & 0.00 \\
\hline & 7 & 1.04 & 1.10 & 1.38 & 1.80 & 2.52 & 3.00 & 3.20 & 3.20 & 3.20 & 3.20 \\
\hline & 8 & .53 & 1.71 & 3.74 & 8.06 & 10.39 & 12.20 & 13.20 & 13.60 & 13.60 & 13.60 \\
\hline & 9 & 3.15 & 4.30 & 5.20 & 6.30 & 6.70 & 7.30 & 7.70 & 8.00 & 8.00 & 8.00 \\
\hline & 10 & 2.43 & 2.30 & 2.20 & 2.10 & 1.80 & 1.70 & 1.60 & 1.50 & 1.50 & 1.50 \\
\hline & 11 & 13.37 & 18.59 & 24.58 & 33.91 & 53.30 & 68.70 & 70.40 & 72.30 & 72.35 & 72.35 \\
\hline & 12 & 52.80 & 58.66 & 66.50 & 66.80 & 65.90 & 63.20 & 63.10 & 63.10 & 63.10 & 63.10 \\
\hline & 13 & 13.37 & 18.59 & 22.43 & 28.25 & 32.10 & 35.77 & 37.42 & 38.35 & 38.35 & 38.35 \\
\hline & 14 & 12.97 & 18.03 & 21.76 & 27.40 & 31.14 & 34.70 & 36.30 & 37.20 & 37.20 & 37.20 \\
\hline & 15 & 0.00 & 0.00 & 2.15 & 8.71 & 21.21 & 30.00 & 33.00 & 34.00 & 34.00 & 34.00 \\
\hline & 16 & 0.00 & 0.00 & 1.40 & 5.66 & 13.79 & 19.50 & 21.45 & 22.10 & 22.10 & 22.10 \\
\hline & 17 & 48.04 & 53.38 & 60.50 & 60.79 & 60.01 & 57.50 & 57.46 & 57.46 & 57.46 & 57.46 \\
\hline 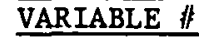 & 18 & 48.04 & 53.38 & 61.90 & 66.45 & 73.80 & 77.00 & 78.91 & 79.56 & 79.56 & 79.56 \\
\hline & 19 & 7.15 & 9.41 & 12.52 & 16.26 & 21.41 & 24.20 & 25.70 & 26.30 & 26.30 & 26.30 \\
\hline & 20 & 6.51 & 8.47 & 11.27 & 14.80 & 19.80 & 22.40 & 23.80 & 24.30 & 24.30 & 24.30 \\
\hline & 21 & 4.15 & 5.00 & 6.70 & 9.40 & 12.00 & 13.80 & 14.30 & 14.30 & 14.30 & 14.30 \\
\hline & 22 & 41.56 & 46.40 & 55.20 & 60.30 & 68.50 & 72.00 & 74.20 & 75.20 & 75.20 & 75.20 \\
\hline & 23 & 3.78 & 4.60 & 5.70 & 7.00 & 8.80 & 9.90 & 10.30 & 10.40 & 10.40 & 40 \\
\hline & 24 & 2.71 & 3.80 & 5.40 & 7.40 & 10.00 & 11.30 & 12.10 & 12.30 & 12.30 & 12.30 \\
\hline & 25 & .02 & .07 & .17 & .40 & 1.00 & 1.20 & 1.40 & 1.60 & 1.60 & 1.60 \\
\hline & 26 & 13.20 & 12.40 & 11.50 & 11.50 & 11.50 & 11.40 & 11.40 & 11.30 & 11.30 & 11.30 \\
\hline & 27 & 9.88 & 14.00 & 20.50 & 22.80 & 26.00 & 27.70 & 28.10 & 28.60 & 28.60 & 28.60 \\
\hline & 28 & 18.49 & 20.00 & 23.20 & 26.00 & 31.00 & $32.90^{\circ}$ & 34.70 & 35.30 & 35.30 & 35.30 \\
\hline & 29 & 16.98 & 17.00 & 17.20 & 18.50 & 20.30 & 21.30 & 21.70 & 21.70 & 21.70 & 21.70 \\
\hline & 30 & 16.73 & 22.80 & 32.80 & 39.60 & 48.00 & 52.80 & 54.50 & 55.20 & 55.20 & 55.20 \\
\hline & 31 & 18.51 & 20.17 & 23.37 & 26.40 & & & & & & 90 \\
\hline & 32 & & & & & & & & & & \\
\hline & 3. & 70.94 & & & & & & & 72 & Sצי & $3 y$ \\
\hline
\end{tabular}


existing proportions, subject to later reallocation if desired). If coal steam is changed, not only will the downstream (demand) variables be corrected, but so will the upstream (supply) variables: \# 14, 13, and 11 .

Allowed values for IACT1 and IACT2 are as.follows:

IACT 1

6

Change Electric

Generation Mix

or Total

7

8

9
Change Direct $0 i 1$ and Gas

Reallocate

Electricity

Reallocate

Oil and Gas
10

18

21

22

23

24

25

O (Sce Diccuccion)

$0,7,8,9,10$

$0,6,8,9,10$

$0,6,7,9,10$

$0,6,7,8,10$

$0,6,7,8,9$

0

0 (See Discussion)

24,25

23,25

23,24

27,28

26,28

26,27 
A decision structure for these corrections is incorporated into the program to permit rapid interactive changes to be made while the program automatically. maintains the consistency requirement. The demand allocation has already been mentioned. In the case of oil and gas, a change to variables $\# 10$ or \# 22 will result in a change to variable \# 18. If the effective change in variable \# 18 (total delivered oil and gas) is to lower it, the impact is passed back to lower the liquid and gas resource ( $\$ 12$ and $\# 17$ ). If the change is an increase in \# 18, the concomitant change is made instead to coal synfuels (variables \#16, 15, and 11). The special command \# 18 was provided to reverse this allocation when desired; oil and gas demand can thus be increase by transferring from synfuels to the direct oil and gas resource category.

The initial data set determines some of the characteristics of these reallocations. The proportion of each fuel to each final demand category is kept the same unless specifically changed. Three of the electric generation categories have their efficiencies calculated according to the initial values of input fuel and output generation in each reference year, so a change in efficiency over time can be simulated.

Time Dependence

As changes are made to activity levels in the various reference years, the user must aim towards developing reasonable time-series in each variable. If one activity in one year is altered, the adjoining years' values will likely also require adjustments to maintain smooth variation in time. Experience is helpful in anticipating the disruptions to assoclated yariables when some change is made. That is, a change in one variable may disrupt the time-series of some other variable. For example, when one resource is to be gradually phased out, another must be brought in to replace it if the total resource consumption is to be maintained 
constant. This procedure can be less than straightforward, however, because of the interdependencies which the program's decision structure are keeping consistent. The user will have to tune the quantities until all variables exhibit satisfactory time-series.

There is one additional command which scales every activity variable in a given reference year: if IACT1 $=0$, then all activities in the reference year IYEAR are multiplied by AMT. This command is useful as the first step in making large changes in the overall level of energy resource consumption.

\section{Interpolation}

On command TPRESG will interpolate values for all variables in all of the 100 years, based on the 10 reference year values that have been set for each variable.

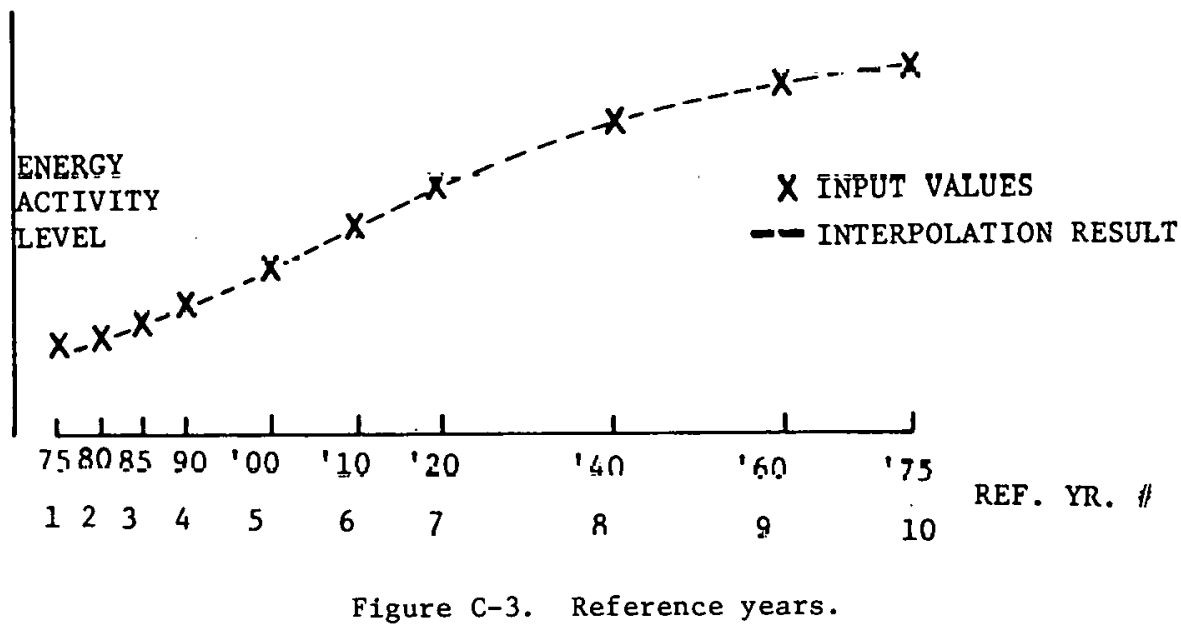


This procedure results in a specification of every energy activity variable in every one of the 101 years. (A library cubic spline interpolation routine is used.)

\section{Calculation of Effects}

Once a satisfactory scenario is completed, the user can instruct TPRESG to calculate the "effects". Each energy activity in each year is then multiplied by appropriate coefficients, to tally total annual system cost, and health and environmental emmissions and effects for that scenario.

\section{TABLE C-2}

\section{COST COEFFICIENTS}

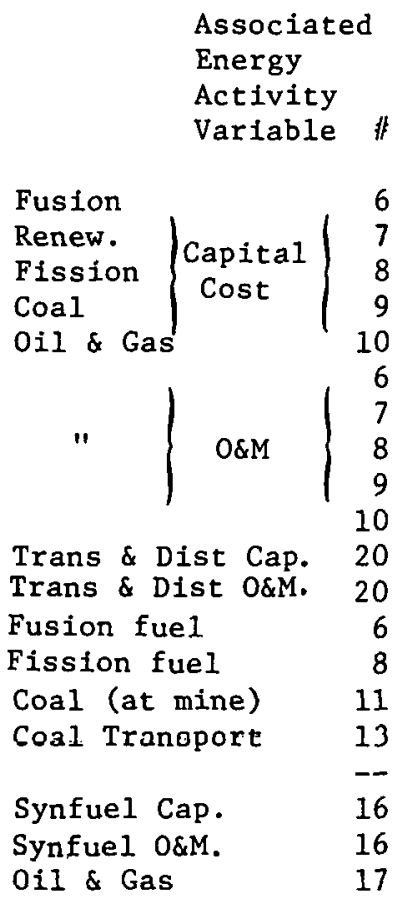

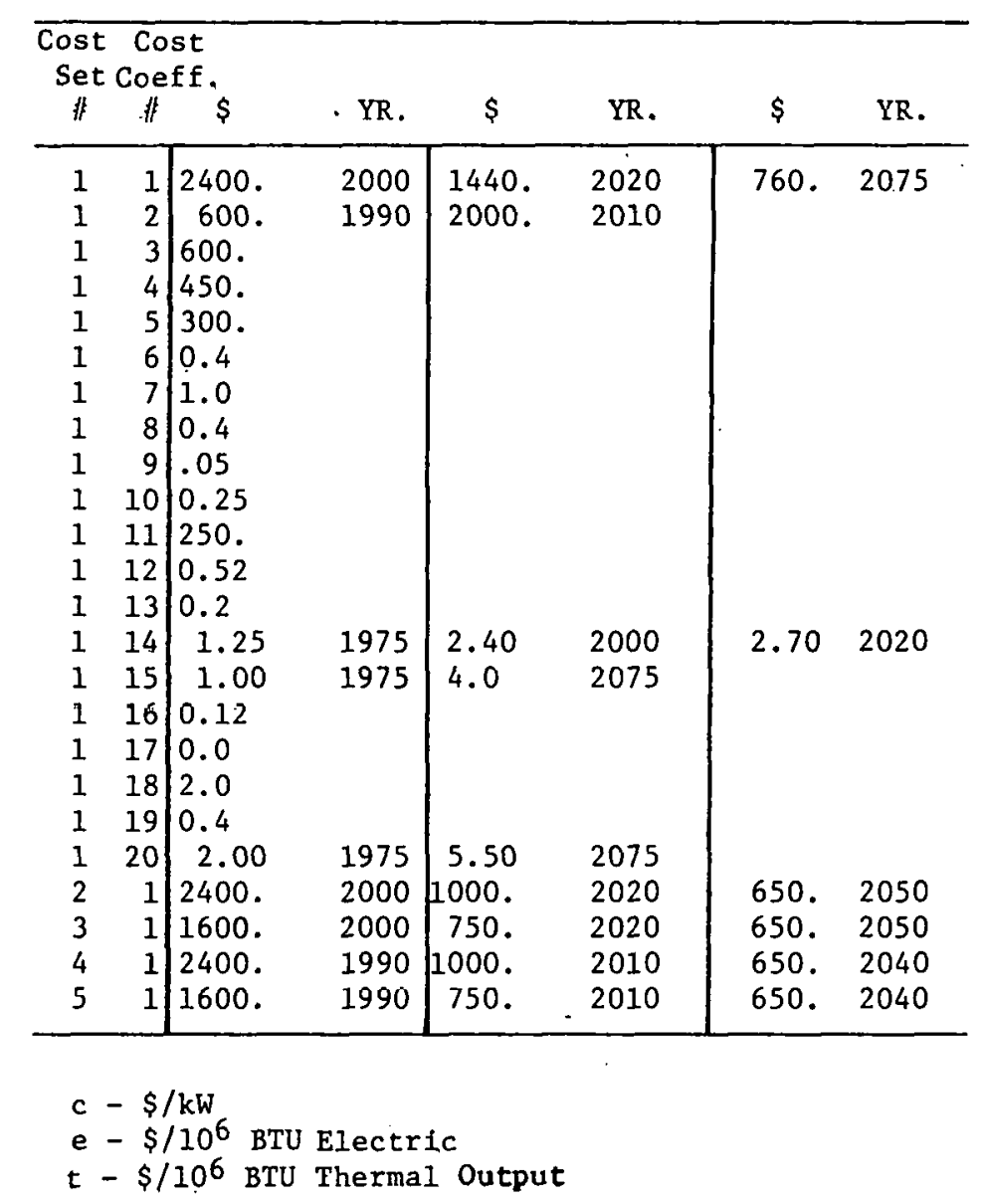


TABLE C-3

HEALTH \& ENVIRONMENTEL EMISSIONS AND EFFECTS COEFFICIENTS

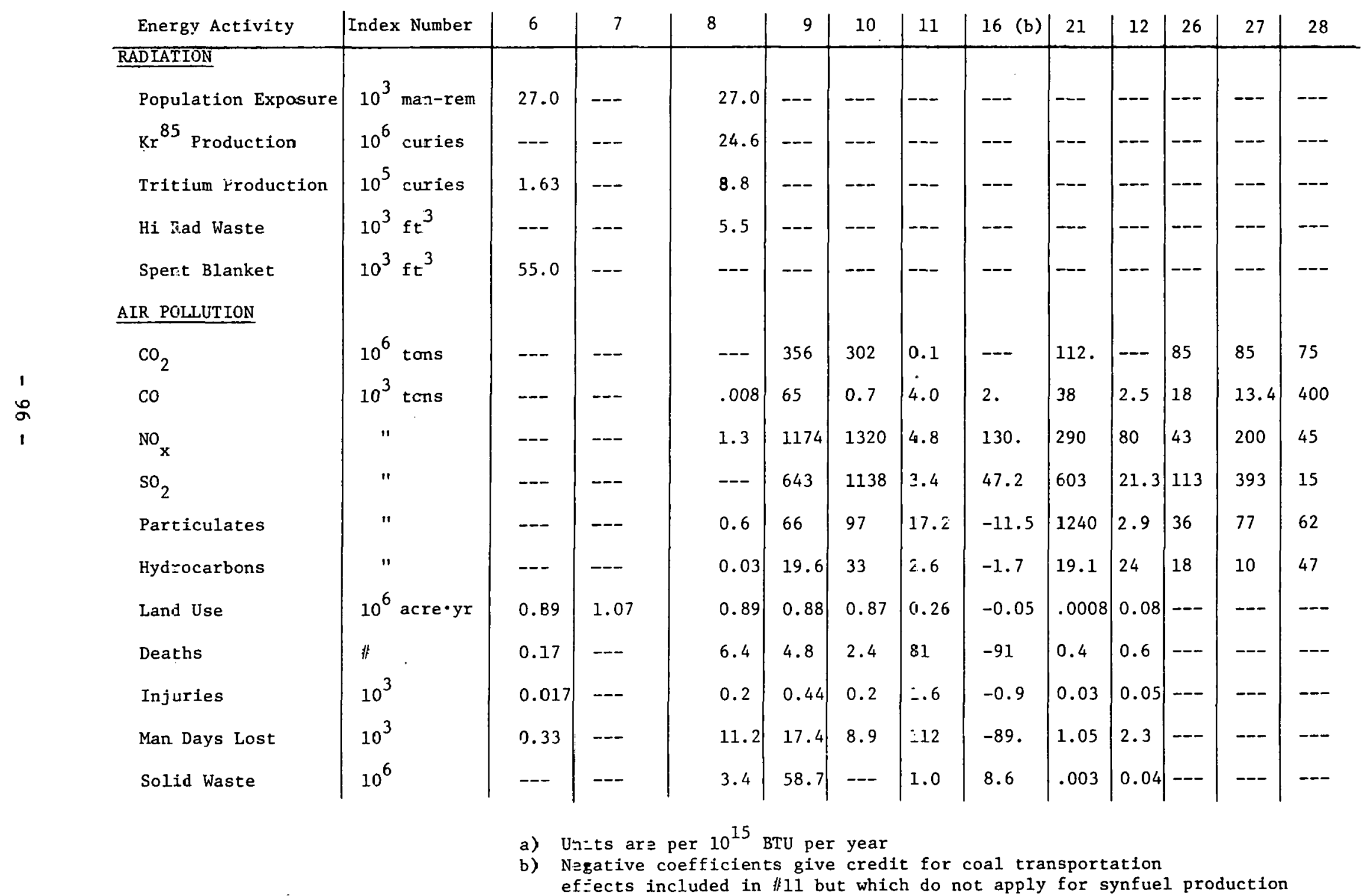


Table $\mathrm{C}-2$ gives the cost information that must be provided to the program. 1) If a single cost number is given (e.g., cost coefficient $\# 4=\$ 450$, ) and no year is specified, then that cost is treated as constant in time. 2) If two or three pairs of cost-year coordinates are specified, a straight line interpolation is performed for times between the points that are given. In cases where the points given do not cover the entire time period from 1975 to 2075 (e.g., \# 14

stops at 2020) the constant value is extended through those years outside the given range.

Up to five distinct "sets" of costs can be used simultaneously. Each successive cost set is the same as the previous one, with any number of changes specified. In the case shown in Table $\mathrm{C}-2$, cost set \# 2 is the same as 1 , but with the fusion capital cost (cost coefficient \# 1) having a different value. In this example, only coefflclent \# 1 has been varied in each of the five different sets of costs.

\section{Cost Calculation}

In each of the 101 years, the annual energy system cost is computed by multiplying each of the energy activity variables by an appropriate cost coefficient and adding. This is done separately for each cost set. Capital costs (coefficient $\# 1-5$, and 11) are first annualized, assuming 30-year plant life (cap1tal recovery factor $\mathrm{CRF}=15 \%$ and a plant factor $\mathrm{PH}$ of 0.8 ).

Annualized Capital Cost $\left(\frac{\$}{10^{6} \cdot \mathrm{BTU}}\right)=\operatorname{Capital} \operatorname{Cost}\left(\frac{\$}{\mathrm{~kW}}\right) \times \frac{\mathrm{CRF}}{29.9 \times \mathrm{PF}}$

Cumulative discounted present value of these annual costs streams are also calculated

$$
\operatorname{DPV}\left(R, \mathrm{Y}_{0}\right)=\sum_{y=Y_{\dot{c}}}^{2076} \mathrm{C}(\mathrm{y}) \frac{1}{(1+R)^{\mathrm{y}-\mathrm{Y}_{0}}}
$$


where $C(y)$ is the annual system cost in the year $y, Y_{0}$ is the starting year for the calculation, and $R$ is the discount rate. Four different start years (1975, 1995, 2010, and 2020) and four different discount rates (0, 5, 10, and 15\%) are applied for each cost set (see Figure C-5). Outputs for costs are in billions of dollars. Note that $\$ 1 / 10^{6} \mathrm{BTU}=\$ 10^{9} / 10^{15} \mathrm{BTU}$, therefore:

$\underset{\text { Tystem Cost }}{\text { Total Annual }}\left(\frac{\$ 10^{9}}{\text { year }}\right)=\sum_{i}$ Energy $_{i}\left(\frac{10^{15} \mathrm{BTU}}{\text { year }}\right) \times \operatorname{Cost}_{i}\left(\frac{\$}{10^{6} \mathrm{BTU}}\right)$

Health and Environmental - Emissions and Effects

Coefficients are shown in Table C-3. The Energy Modeling Data Base (EMDB) provides highly specific coefficients at the individual process level for various emissions and effects resulting from energy conversion and use activities.* These coefficients are in the form of amount of pollutant, or number of injuries, per BTU of energy flow. Coefficients were taken from the Data Base with an attempt to select the most representative or reasonable estimates for the more aggregated energy flow activities in TPRESG. Resulting totals should give an approximate feeling for the relative burdens to the environment imposed in the different scenarios. It should be noted, however, that it is not possible to establish truly meaningful coefficients at that level of aggregation because the individual technologies vary greatly in their characteristic emissions. (Base case fuel allocations in more detailed studies** were used to arrive at prorated coefficients for the highly aggregated TPRESG energy activity variables.)

* Energy Modeling Data Base, User's Manual, Energy Environmental Group, M. Goldberg, BNL Report No. 19200 .

** Sourcebook, BNL Report No. 50483. 
The Program Flow Chart is shown in Figure $\mathrm{C}-4$. After reading the input data, the user can choose from among eight interactive commands. Most are selfexplanatory. The Activity Change (\#1) stays within its own loop for successive instructions, until a command is given with IACT1 $=-1$. The restart (k 5) permits a fresh start under the initial conditions, if needed. The Selected Print (\# 7), which was used to type Table $C-1$, allows any number of variables to be printed quickly, and the full output (\# 4) has an option to print various (any from among the four) subsections of the full output. (Figure C-5)

The Interpolate (\# 2) and Effects. (\# 3) must be used prior to any Printout or Output File Write (\# 6), during which a line of test can be input as the case title. Figure $\mathrm{C}-5$ gives the complete printout which results from the print command (\# 4). Several additional features are:

1) Average annual percentage growth rates implied by the change in the activity variable from that reference year to the next reference year. For example, the increase of coal from 13.37 Quad in 1975 to 25.80 Quad in 1980 represents an average annual \% growth rate of $13.1 \%$ over that five-year period.

2) The electrification ratio given in the third row, adjacent to total delivered electricity, is calculated thus:

$$
\text { Electrification Ratio }=\frac{\text { Electricity }}{\text { Liq. \& Gas. }+ \text { Coal }+ \text { Electricity }}
$$

where all fuels are as delivered (variables \# 22, 21, and 20.)

3) Total resource and fuel use are defined as variables \# 33 and 32 , respectively, and are defined on Figure C-2. 


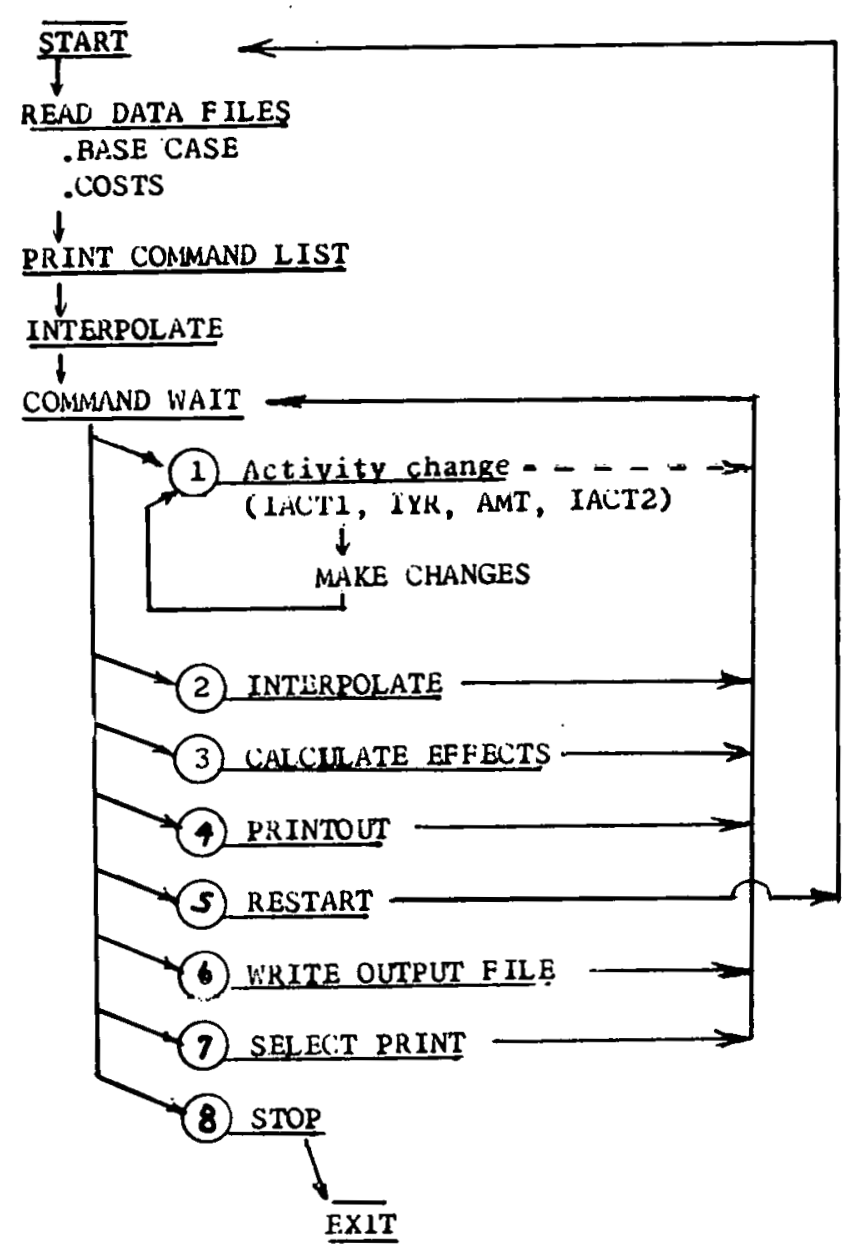

Figure C-4. TPRESG program flow chart. 
THIS PAGE

WAS INTENTIONALLY

LEFT BLANK 
IIZOI HIGH-ZEG LASE EASE FOSSIL RESDURCES
TOTAL USE

CLECIRIC GENERATION RESOURCE USE (THE FIAAL)

$\begin{array}{lc}\text { YEAR LIN \& GAS } \\ \text { 3975 } & 52.80 \\ 1980 & 58.66 \\ 1985 & 66.50 \\ 1990 & 65.80 \\ 2000 & 65.90 \\ 2010 & 63.20 \\ 2020 & 63.10 \\ 2040 & 63.10 \\ 2060 & 63.10 \\ 2075 & 63.10\end{array}$

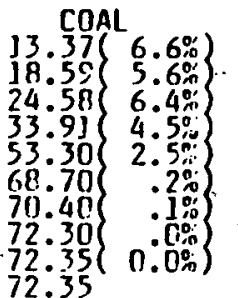

$\begin{array}{cccc}\text { I.IN } 8 \text { CAS } & \text { COAL } & \text { FISSION } & \text { CIR } \\ 6.48 & 0.112 & 1.65 & 0.00 \\ 6.98 & 13.03 & 5.34 & 0.00 \\ 6.70 & 14.86 & 11.33 & 0.00 \\ 6.15 & 18.00 & 23.97 & 0.00 \\ 5.30 & 19.14 & 28.86 & 0.00 \\ 5.00 & 20.90 & 33.80 & 0.00 \\ 4.71 & 22.00 & 35.80 & 0.00 \\ 4.36 & 22.90 & 36.80 & 0.00 \\ 4.36 & 22.90 & 36.80 & 0.00 \\ 4.36 & 22.90 & 36.80 & 0.10\end{array}$

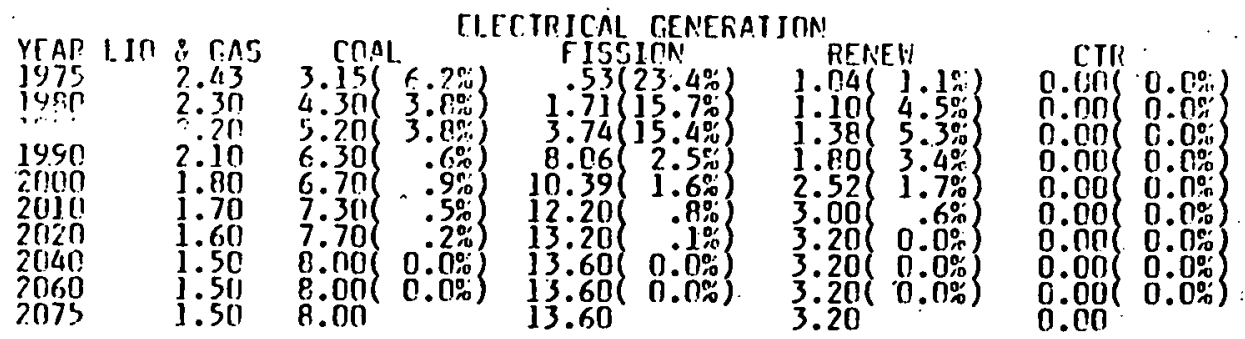

YFAR
1975
1980
1985
1990
20060
2010
20100
2040
2060
2075

COAL IN SYNFUELS

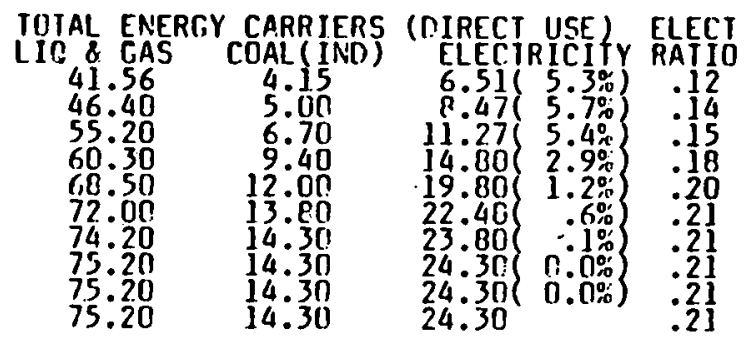

FINAL CONSUMPTION FND USE

$\begin{array}{ll}\text { YrAR } & R \times C \\ 1975 & 13.20 \\ 1900 & 12.40 \\ 3985 & 13.50 \\ 1990 & 11.50 \\ 2010 & 11.50 \\ 2010 & 11.40 \\ 2020 & 11.40 \\ 201100 & 11.30 \\ 2060 & 11.30 \\ 2075 & 11.30\end{array}$

\section{In \& GAS}

$\begin{array}{rr}\text { TRANS } \\ \text { INU } & \text { TRA. } 18.49 \\ 9.80 & 20.00 \\ 14.100 & 20.50 \\ 20.50 & 23.20 \\ 22.80 & 26.00 \\ 26.00 & 31.00 \\ 27.70 & 32.90 \\ 28.10 & 34.70 \\ 20.60 & 35.30 \\ 28.60 & 35.30 \\ 28.60 & 35.30\end{array}$

\begin{tabular}{rrr}
\multicolumn{3}{c}{ ELECTRICITY } \\
$R \& C$ & IND & TRANS \\
3.78 & 2.71 & .02 \\
4.60 & 3.80 & .07 \\
5.70 & 5.40 & .17 \\
7.00 & 7.40 & .40 \\
8.80 & 10.00 & 1.00 \\
9.90 & 11.30 & 1.20 \\
10.30 & 12.10 & 3.40 \\
10.40 & 12.30 & 1.60 \\
10.40 & 12.30 & 1.60 \\
10.40 & 12.30 & 1.60
\end{tabular}

TOTALS

\begin{tabular}{|c|c|c|c|c|c|}
\hline $\begin{array}{l}\text { YEAR } \\
1975 \\
1960 \\
3965 \\
1990 \\
2000 \\
2010 \\
2020 \\
2040 \\
2060 . \\
2075\end{array}$ & $\begin{array}{l}R \& C \\
16.09 \\
17.00 \\
17.20 \\
18.50 \\
20.30 \\
21.30 \\
21.70 \\
21.70 \\
21.70 \\
21.70\end{array}$ & $\begin{array}{l}\text { IND } \\
16.73 \\
22.80 \\
32.110 \\
39.100 \\
48.00 \\
52.80 \\
54.50 \\
55.20 \\
55.20 \\
55.20\end{array}$ & $\begin{array}{l}\text { IRANS } \\
10.51 \\
20.17 \\
23.37 \\
26.40 \\
32.00 \\
34.10 \\
36.10 \\
36.90 \\
36.90 \\
36.90\end{array}$ & $\begin{array}{r}101.15[ \\
52.22 \\
59.97 \\
73.37 \\
84.50 \\
110.30 \\
108.20 \\
112.30 \\
113.80 \\
13.80 \\
113.80\end{array}$ & $\begin{array}{r}\text { TOI RES } \\
70.94 \\
85.73 \\
106.04 \\
129.82 \\
155.26 \\
174.30 \\
178.44 \\
181.34 \\
181.39 \\
181.39\end{array}$ \\
\hline
\end{tabular}

\begin{tabular}{|c|c|}
\hline & $\begin{array}{c}\text { Cl!t.1. Pi } \\
1975-2024\end{array}$ \\
\hline $\begin{array}{l}\text { InTML CUIAL } \\
\text { IOIAL IIIS \& TAS }\end{array}$ & $\begin{array}{l}2414 . \\
3176 .\end{array}$ \\
\hline
\end{tabular}

Figure C-5. Energy activity levels national annual totals (E15 BTU). 
IITTAL APINIJAL SYSTEN COST (I9 DOLLARS)

\begin{tabular}{|c|c|c|c|c|c|}
\hline $\begin{array}{l}\text { YEAR } \\
1075 \\
1980 \\
1915 \\
1990 \\
2000 \\
2010 \\
2020 \\
2040 \\
2060 \\
2075\end{array}$ & $\begin{array}{l}\text { SET1 } \\
148.1 \\
193.5 \\
251.2 \\
333.7 \\
461.4 \\
574.5 \\
639.4 \\
733.7 \\
817.5 \\
880.2\end{array}$ & $\begin{array}{l}\text { CET2 } \\
\text { SET } \\
149.1 \\
191.5 \\
25,4.2 \\
82.57 \\
461.4 \\
534.5 \\
639.4 \\
733.7 \\
817.5 \\
880.2\end{array}$ & $\begin{array}{r}\text { AST ASUAPIIO } \\
5 F 13 \\
\text { j48.1 } \\
191.5 \\
254.2 \\
333.7 \\
461.4 \\
5735.5 \\
639.4 \\
733.7 \\
817.5 \\
\text { B80.2 }\end{array}$ & $\begin{array}{l}\text { NS SETS } \\
\text { \$[T T4 } \\
348.1 \\
191.5 \\
254.2 \\
333.5 \\
461.4 \\
534.5 \\
639.4 \\
733.7 \\
817.5 \\
8 B 0.2\end{array}$ & $\begin{array}{l}5[15 \\
]<18.1 \\
19] .5 \\
25 \% .2 \\
333.5 \\
461.4 \\
574.5 \\
639.4 \\
733.7 \\
817.5 \\
800.2\end{array}$ \\
\hline $\begin{array}{c}\mathrm{T} 0_{0 \%}^{1975} \\
0 \% \\
10 \% \\
15 \% \\
15 \%\end{array}$ & $\begin{array}{l}\text { DISCUUNI } \\
61238.2 \\
7483.0 \\
2868.6 \\
1691.3\end{array}$ & $\begin{array}{l}\text { PRESENT } \\
61238.2 \\
7483.0 \\
2868.6 \\
1691.3\end{array}$ & 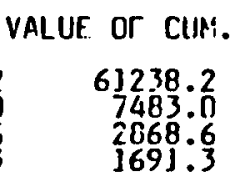 & $\begin{array}{c}\text { SYSTEH COST } \\
61238.2 \\
7483.0 \\
2868.6 \\
1691.3\end{array}$ & $\begin{array}{r}61238.2 \\
7483.0 \\
2868.6 \\
1691.3\end{array}$ \\
\hline Tn 1995 & $\begin{array}{r}56099.2 \\
11660.7 \\
5552.2 \\
3649.0\end{array}$ & $\begin{array}{r}56099.2 \\
11660.7 \\
5552.2 \\
3649.0\end{array}$ & $\begin{array}{r}56099.2 \\
11660.7 \\
5552.2 \\
3649.0\end{array}$ & $\begin{array}{r}56099.2 \\
11660.7 \\
5552.2 \\
3649.0\end{array}$ & $\begin{array}{r}56099.2 \\
11660.7 \\
5552.2 \\
3649.0\end{array}$ \\
\hline 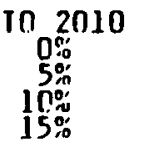 & $\begin{array}{r}48931.6 \\
13501.5 \\
6957.9 \\
4729.4\end{array}$ & $\begin{array}{r}48831.6 \\
13501.5 \\
6957.9 \\
4729.4\end{array}$ & $\begin{array}{r}48831.6 \\
13501.5 \\
6957.9 \\
4729.4\end{array}$ & $\begin{array}{r}48031.6 \\
13501.5 \\
6957.9 \\
4729.4\end{array}$ & $\begin{array}{r}48631.0 \\
13501.5 \\
6957.9 \\
4729.4\end{array}$ \\
\hline $\begin{array}{c}\text { TO } 2020 \\
0 \% \\
5 \% \\
10 \% \\
15 \% \\
15 \% \\
5 \%\end{array}$ & $\begin{array}{r}42766.7 \\
14017.7 \\
7504.6 \\
5145.6\end{array}$ & $\begin{array}{r}42766.7 \\
14017.7 \\
7504.6 \\
5145.6\end{array}$ & $\begin{array}{r}42766.7 \\
14017.7 \\
7504.6 \\
5145.6\end{array}$ & $\begin{array}{r}42766.7 \\
14017.7 \\
7504.6 \\
5145.6\end{array}$ & $\begin{array}{r}42766.7 \\
14017.7 \\
7504.6 \\
5145.6\end{array}$ \\
\hline
\end{tabular}

HCALTH \& ENVIRON - EMISSIONS \& EFFECTS

\begin{tabular}{|c|c|c|c|c|c|c|}
\hline $\begin{array}{l}\text { YEAR } \\
1975 \\
1980 \\
1985 \\
1990 \\
2000 \\
2010 \\
2020 \\
2040 \\
2060\end{array}$ & $\begin{array}{l}\text { POP EXP } \\
\text { E } 3 \\
\text { MAN REH } \\
14.31 \\
46.17 \\
100.98 \\
217.62 \\
280.53 \\
329.40 \\
356.40 \\
367.20 \\
367.20 \\
367.20\end{array}$ & $\begin{array}{r}K R-B 5 \\
\text { E6 } \\
\text { CURIES } \\
13.64 \\
42.07 \\
92.00 \\
198.28 \\
255.59 \\
3100.12 \\
324.72 \\
334.56 \\
334.56 \\
334.56\end{array}$ & $\begin{array}{r}\text { TRIT } \\
\text { E5 } \\
\text { CIRIES } \\
4.66 \\
1 ! .05 \\
32.91 \\
70.93 \\
91.43 \\
107.36 \\
116.16 \\
199.68 \\
119.68 \\
119.68\end{array}$ & $\begin{array}{c}\text { RAD WASTE } \\
\text { E3 } \\
\text { CU FI } \\
2.92 \\
9.41 \\
20.57 \\
44.33 \\
57.15 \\
67.10 \\
72.60 \\
74.80 \\
74.80 \\
74.80\end{array}$ & $\begin{array}{c}\text { SPENT } \\
\text { BLANKE } \\
\text { E } 3 \text { CU F } \\
0.00 \\
0.00 \\
0.00 \\
0.00 \\
0.00 \\
0.00 \\
0.00 \\
0.00 \\
0.00 \\
0.00\end{array}$ & $\begin{array}{l}0.001 \\
0.00 \\
0.00 \\
0.001 \\
0.00 \\
0.00 \\
0.00 \\
0.00 \\
0.00 \\
0.00\end{array}$ \\
\hline $\begin{array}{l}\text { YEAR } \\
1975 \\
1980 \\
1985 \\
1990 \\
2000 \\
2010 \\
2020 \\
2040 \\
2060\end{array}$ & $\begin{array}{c}\text { CO2 } \\
\text { F.9 TONS } \\
5.67 \\
6.53 \\
7.73 \\
8.80 \\
9.79 \\
10.46 \\
10.79 \\
10.95 \\
10.95 \\
10.95\end{array}$ & $\begin{array}{c}\text { CO } \\
\text { EG IONS } \\
8.32 \\
9.10 \\
10.62 \\
31.99 \\
14.25 \\
15.21 \\
15.99 \\
16.26 \\
16.26 \\
16.26\end{array}$ & $\begin{array}{c}\text { NOX } \\
\text { E6 IONS } \\
18.08 \\
21.19 \\
25.42 \\
28.611 \\
31.90 \\
34.17 \\
35.11 \\
35.59 \\
35.54 \\
35.59\end{array}$ & $\begin{array}{c}\text { SO2 } \\
\text { E6 TONS } \\
14.12 \\
16.91 \\
21.16 \\
24.56 \\
27.81 \\
30.12 \\
30.84 \\
31.15 \\
31.15 \\
31.15\end{array}$ & $\begin{array}{c}\text { PARI } \\
\text { E } 6 \text { IONS } \\
8.36 \\
9.96 \\
12.90 \\
16.77 \\
20.79 \\
23.49 \\
24.28 \\
24.38 \\
24.38 \\
24.38\end{array}$ & $\begin{array}{c}\text { HC } \\
\text { TONS } \\
2.73 \\
3.02 \\
3.46 \\
3.71 \\
4.04 \\
4.15 \\
4.26 \\
4.29 \\
4.29 \\
4.29\end{array}$ \\
\hline $\begin{array}{l}\text { YEAR } \\
1975 \\
1900 \\
1985 \\
1990 \\
2000 \\
2010 \\
2020\end{array}$ & $\begin{array}{l}\text { LAND UST } \\
\text { E6 ACRES } \\
14.17 \\
18.191 \\
22.94 \\
30.36 \\
37.86 \\
3.93 \\
45.63 \\
46.63 \\
46.64 \\
46.614\end{array}$ & $\begin{array}{l}1.96 \\
2.96 \\
3.21 \\
3.95 \\
3.92 \\
1.92 \\
11.19 \\
4.19\end{array}$ & $\begin{array}{c}\text { INJURJES } \\
\text { E3 } \\
26.12 \\
35.51 \\
45.05 \\
57.56 \\
6 ! .87 \\
163.89 \\
103.22 \\
119.079 \\
119.25 \\
169.99\end{array}$ & $\begin{array}{c}\text { HAAN DAYS } \\
\text { LOST } 56 \\
1.71 \\
2.34 \\
2.94 \\
3.69 \\
5.16 \\
6.40 \\
6.43 \\
6.601 \\
6.601 \\
6.611\end{array}$ & $\begin{array}{c}\text { SQL ID WASTE } \\
\text { E9 TCNS } \\
.20 \\
.28 \\
.36 \\
.48 \\
.60 \\
.71 \\
.75 \\
.78 \\
.78 \\
.76\end{array}$ & \\
\hline
\end{tabular}

Figure C-5. (Continued) 


\section{THIS PAGE}

\section{WAS INTENTIONALLY \\ LEFT BLANK}


APPENDIX D

SCENARIO PRINTOUTS

$-105-$ 


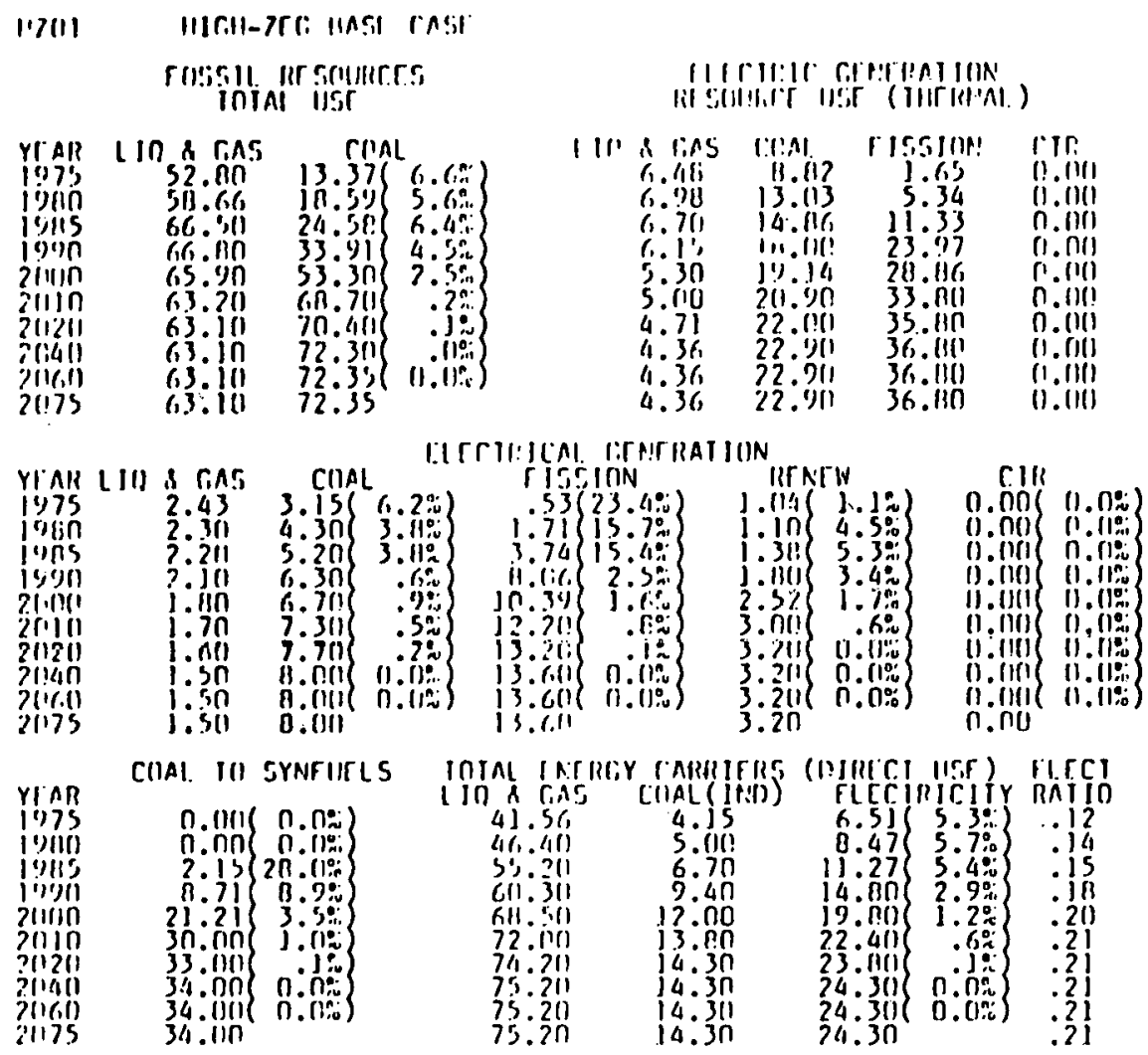

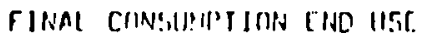

\begin{tabular}{|c|c|c|c|}
\hline \multirow[b]{2}{*}{ YI All } & \multicolumn{3}{|c|}{ III I:AS } \\
\hline & & INII $^{10,3}$ & Illak:4; \\
\hline & 13. & $9.111]$ & {$[1(.4 i)$} \\
\hline !?!n & 12.40 & 14.00 & 311.111 \\
\hline isils, & & 20.30 & 33.211 \\
\hline [y') & : & 22. (ii) & $28 . .111$ \\
\hline $2(1 n 11$ & 11.50 & 26.010 & $31.11 n$ \\
\hline$?(1) 11$ & 31.41 & 27.70 & 1 \\
\hline ?11211 & .41 & 211.111 & 1.71 \\
\hline$?(14)$ & .30 & 20.0 .0 & .31 \\
\hline & 11.30 & 211.6 .11 & 35.311 \\
\hline 217 & 11.311 & $213.6 n$ & .311 \\
\hline
\end{tabular}

\begin{tabular}{|c|c|c|}
\hline \multicolumn{3}{|c|}{ 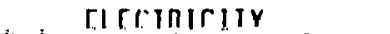 } \\
\hline 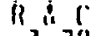 & $(N \mid)$ & TIRANS \\
\hline $\begin{array}{l}3.781 \\
4.6,01\end{array}$ & 2.71 & . \\
\hline $\begin{array}{l}4.6 .11 \\
5.711\end{array}$ & 3.80 & \\
\hline 7.1111 & 5.41 & \\
\hline 8.811 & 10.00 & . $\cap 11$ \\
\hline 9 & 301 & .23 \\
\hline 10.30 & .10 & 48 \\
\hline 10.41 & 30 & $0,1]$ \\
\hline 111.411 & $12.3 n$ & 6,1 \\
\hline$] 11.411$ & 12.30 & fil \\
\hline
\end{tabular}

IIIINI. 5

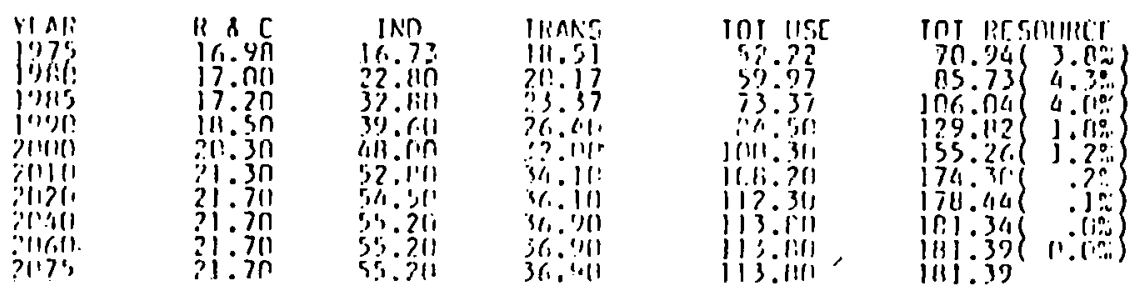




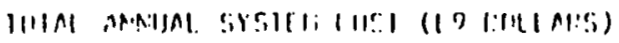

\begin{tabular}{|c|c|c|c|}
\hline \multirow{2}{*}{\multicolumn{4}{|c|}{ צו ום }} \\
\hline & & & \\
\hline 1979, & 1481 & & it \\
\hline jon & ji1: & $191 . \frac{1}{5}$ & 191- \\
\hline igns & 254.2 & 254.2 & $234: 2$ \\
\hline$j 900$ & 333.7 & 333.7 & 333.7 \\
\hline $20 n$ & $46,1.4$ & 461.4 & 461.4 \\
\hline $2 ! ! 10$ & 574.5 & 374.5 & 574.5 \\
\hline $2[1,1]$ & 933.7 & 733.7 & 733.7 \\
\hline 201000 & (11) 7.5 & B] 7.5 & 017.5 \\
\hline 7 & กกเ & $n+n=.2$ & 8 8no. \\
\hline
\end{tabular}

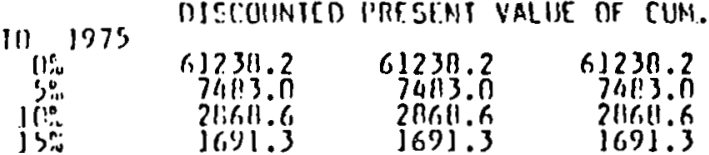

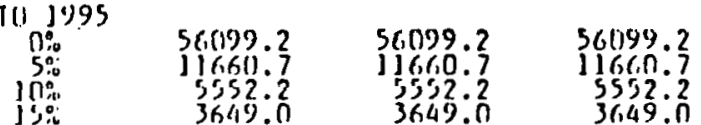

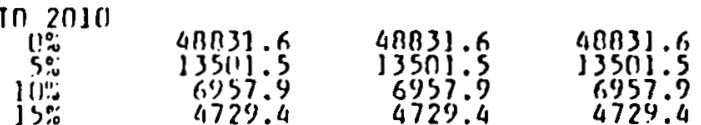

$\begin{array}{cccc}1112020 & & & \\ 1100 & 42766.7 & 42766.7 & 42766.7 \\ 5 \% & 14(117.7 & 14017.7 & 14017.7 \\ 10 \% 0 & 7504.6 & 7504.6 & 7504.6 \\ 15 \% & 5145.6 & 5145.6 & 5145.6\end{array}$

IIEAL III \& ENVIRON - EMISSIONS \& EFFFCIS

\begin{tabular}{|c|c|c|c|c|c|c|}
\hline $\begin{array}{l}Y 5 A n \\
1975 \\
19001 \\
1905 \\
1990 \\
2000 \\
20100 \\
20100 \\
20140 \\
2060 \\
2075\end{array}$ & $\begin{array}{r}\text { POP EXP } \\
{[3} \\
\text { MAN REN } \\
11.31 \\
46.17 \\
100.94 \\
217.62 \\
210.53 \\
329.40 \\
356.90 \\
367.20 \\
367.20 \\
367.20\end{array}$ & $\begin{array}{r}K R-85 \\
56 \\
\text { CIIIII. } \\
13.04 \\
42.07 \\
92.01 \\
198.20 \\
255.59 \\
300.12 \\
324.72 \\
334.56 \\
334.56 \\
334.56\end{array}$ & $\begin{array}{r}\text { IRIT } \\
\text { CS } \\
\text { CURIIS } \\
4.66 \\
15.05 \\
32.91 \\
70.93 \\
91.43 \\
107.36 \\
116.96 \\
119.68 \\
119.619 \\
119.68\end{array}$ & $\begin{array}{c}\text { RAD WASIE } \\
\text { E. } \\
\text { CII F } \\
2.92 \\
9.41 \\
20.57 \\
44.33 \\
57.15 \\
67.10 \\
72.010 \\
74.010 \\
74.010 \\
74.00\end{array}$ & 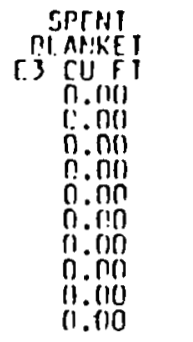 & 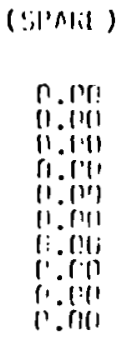 \\
\hline $\begin{array}{l}\text { Ycan } \\
1975 \\
\text { jonn } \\
1905 \\
1900 \\
20 n 0 \\
20101 \\
2020 \\
2600 \\
2060 \\
2075\end{array}$ & $\begin{array}{c}c 02 \\
6.910 \mathrm{Ns} \\
5.67 \\
6.53 \\
7.73 \\
91.00 \\
9.79 \\
30.96 \\
10.79 \\
10.95 \\
10.95 \\
10.95\end{array}$ & $\begin{array}{r}c 0 \\
\text { C6 TnNS } \\
0.32 \\
9.10 \\
11.62 \\
11.99 \\
14.25 \\
15.21 \\
15.91 \\
16.26 \\
16.26 \\
16.26\end{array}$ & $\begin{array}{r}\text { NOX } \\
\text { E. } 10 N S \\
10.08 \\
21.19 \\
25.42 \\
2 B .90 \\
31.90 \\
34.17 \\
35.11 \\
35.59 \\
35.59 \\
35.59\end{array}$ & $\begin{array}{c}902 \\
{[6 \quad 110 \times 5} \\
34.12 \\
16.91 \\
21.16 \\
24.56 \\
27.81 \\
30.12 \\
30.14 \\
31: 15 \\
31.15 \\
31.15\end{array}$ & $\begin{array}{r}\text { PARI } \\
\text { C610N5 } \\
0.36 \\
9.96 \\
12.901 \\
16.77 \\
20.79 \\
23.49 \\
24.211 \\
24.311 \\
24.36 \\
24.36\end{array}$ & 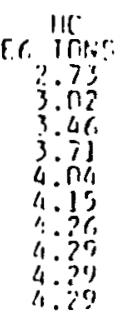 \\
\hline 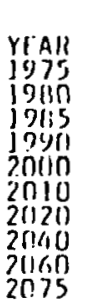 & $\begin{array}{l}\text { LANI) } 1155 \\
\text { EG ACRC } \\
34.17 \\
111.11 \\
22.94 \\
30.36 \\
39.86 \\
43.93 \\
45.63 \\
46.63 \\
46.014 \\
46.04\end{array}$ & 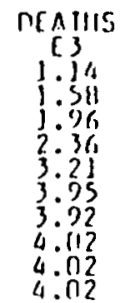 & $\begin{array}{l}\text { INJURIES } \\
\text { I.3 } \\
26.12 \\
35.51 \\
45.05 \\
57.56 \\
01.87 \\
109.89 \\
1013.22 \\
3115.07 \\
105.95 \\
105.05\end{array}$ & $\begin{array}{c}\text { IAN DAYS } \\
\text { LUSTE6 } \\
3.71 \\
2.34 \\
2.94 \\
3.60 \\
5.16 \\
6.411 \\
6.193 \\
6.6(1) \\
6.101 \\
6.40\end{array}$ & 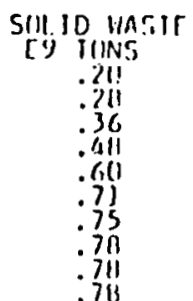 & \\
\hline
\end{tabular}

Figure D-1. Continued. 
FOSSIL RESOURCES

TOIAL USE

$\begin{array}{lc}\text { YEAR } & \text { LIO \& CAS } \\ 1975 & 52.80 \\ 1980 & 58.66 \\ 1985 & 66.50 \\ 1990 & 66.80 \\ 2000 & 65.90 \\ 2010 & 63.20 \\ 2020 & 63.10 \\ 2040 & 63.10 \\ 2060 & 63.10 \\ 2075 & 63.10\end{array}$

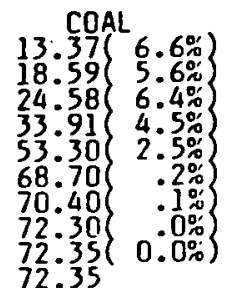

ELECTRIC GENERATION RESOURCE USE (THERMAL)

LIO

$\begin{array}{lccc}\& \text { GAS } & \text { COAL } & \text { FISSION } & \text { CTR } \\ 6.48 & 8.82 & 1.65 & 0.00 \\ 6.98 & 13.03 & 5.34 & 0.00 \\ 6.70 & 14.86 & 11.33 & 0.00 \\ 6.15 & 14.00 & 23.97 & 0.00 \\ 5.30 & 19.14 & 28.86 & 0.00 \\ 5.00 & 20.90 & 33.80 & 0.00 \\ 4.71 & 22.00 & 35.80 & 0.00 \\ 4.36 & 22.90 & 36.80 & 0.00 \\ 4.36 & 22.90 & 36.80 & 0.00 \\ 4.36 & 22.90 & 36.80 & 0.00\end{array}$

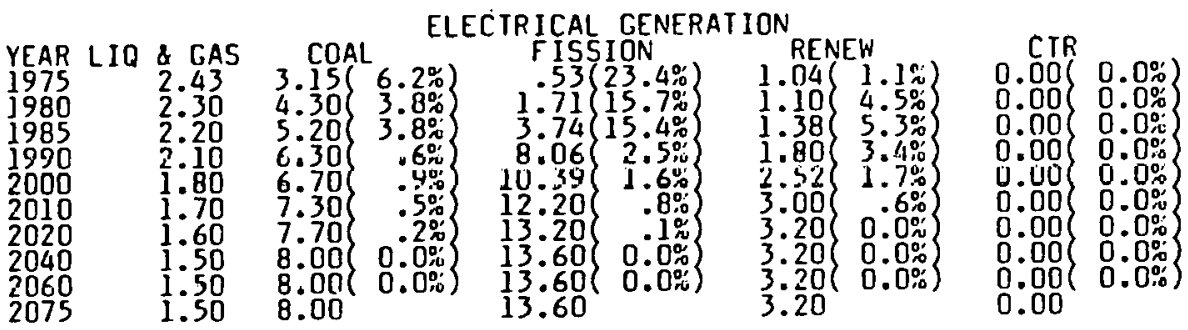

YEAR
1975
1980
1985
1990
2000
2010
2020
2040
2060
2075

COAL TO SYNFUELS

$\begin{array}{cc}\text { TOTAL ENERCY CARRIERS } \\ \text { LIO \& GAS } \\ 41.56 \text { COL (IND) } \\ 41.56 \\ 46.40 & 5.00 \\ 55.20 & 6.70 \\ 60.30 & 9.40 \\ 68.50 & 12.00 \\ 72.80 & 13.80 \\ 74.20 & 14.30 \\ 75.20 & 14.30 \\ 75.20 & 14.30 \\ 75.20 & 14.30\end{array}$

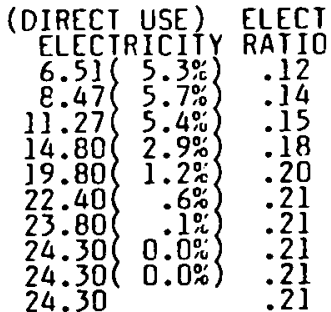

FINAL CONSUMPTION END USE

$\begin{array}{ll}\text { YEAR } & R \& C \\ 1975 & 13.20 \\ 1980 & 12.40 \\ 1915 & 11.511 \\ 1990 & 11.50 \\ 2000 & 11.50 \\ 2010 & 11.40 \\ 2020 & 11.40 \\ 2040 & 11.30 \\ 2060 & 11.30 \\ 2075 & 11.30\end{array}$

LIO \& GAS

$\begin{array}{rr}\text { IND } & \text { TRANS } \\ 9.88 & 18.49 \\ 14.00 & 20.00 \\ 20.50 & 23.20 \\ 22.80 & 26.00 \\ 26.00 & 31.00 \\ 27.70 & 32.90 \\ 28.10 & 34.70 \\ 28.60 & 35.30 \\ 28.60 & 35.30 \\ 28.60 & 35.30\end{array}$

\begin{tabular}{rrr}
\multicolumn{3}{c}{ ELECTRICITY } \\
R\&C TRANS \\
3.78 & 2.71 & IRAND \\
4.60 & 3.80 & .02 \\
5.70 & 5.40 & .07 \\
7.00 & 7.40 & .46 \\
8.80 & 10.00 & 1.00 \\
9.90 & 11.30 & 1.20 \\
10.30 & 12.10 & 1.40 \\
10.40 & 12.30 & 1.60 \\
10.40 & 12.30 & 1.60 \\
10.40 & 12.30 & 1.60
\end{tabular}

TOTALS

\begin{tabular}{|c|c|c|c|c|c|}
\hline $\begin{array}{l}\text { YEAR } \\
1975 \\
1980 \\
1985 \\
1990 \\
2000 \\
2010 \\
2020 \\
2040 \\
2060 \\
2075\end{array}$ & $\begin{array}{l}R \& C \\
16.98 \\
17.00 \\
17.20 \\
18.50 \\
20.30 \\
21.30 \\
21.70 \\
21.70 \\
21.70\end{array}$ & $\begin{array}{l}\text { IND } \\
16.73 \\
22.80 \\
32.80 \\
39.60 \\
48.00 \\
52.80 \\
54.50 \\
55.20 \\
55.20\end{array}$ & $\begin{array}{l}\text { TRANS } \\
18.51 \\
20.17 \\
23.37 \\
26.40 \\
32.00 \\
34.10 \\
36.10 \\
36.90 \\
36.90\end{array}$ & $\begin{array}{r}\text { TOI USE } \\
52.22 \\
59.27 \\
73.37 \\
84.50 \\
100.30 \\
108.20 \\
112.30 \\
113.80 \\
113.80\end{array}$ & $\begin{array}{r}T \cap T \text { PESS } \\
70.94 \\
85.73 \\
106.04 \\
129.82 \\
155.26 \\
174.30 \\
178.44 \\
181.34 \\
181.39 \\
181\end{array}$ \\
\hline
\end{tabular}

$$
\begin{array}{cccc} 
& \multicolumn{4}{c}{\text { CUM RESOURCE USE }} & \\
& 1975-2024 & 1995-2044 & 1975-2075 \\
\text { INIAL COAL } & 2414 . & 3334 . & 6090 . \\
\text { TOTAL LIO \& CAS } & 3176 . & 3187 . & 6395 .
\end{array}
$$

Figure D-2. Energy activity levels national annual totals (E15 Btu). 
TOIAL AMNUAL SYSTEM CAST (E COLLAPS)

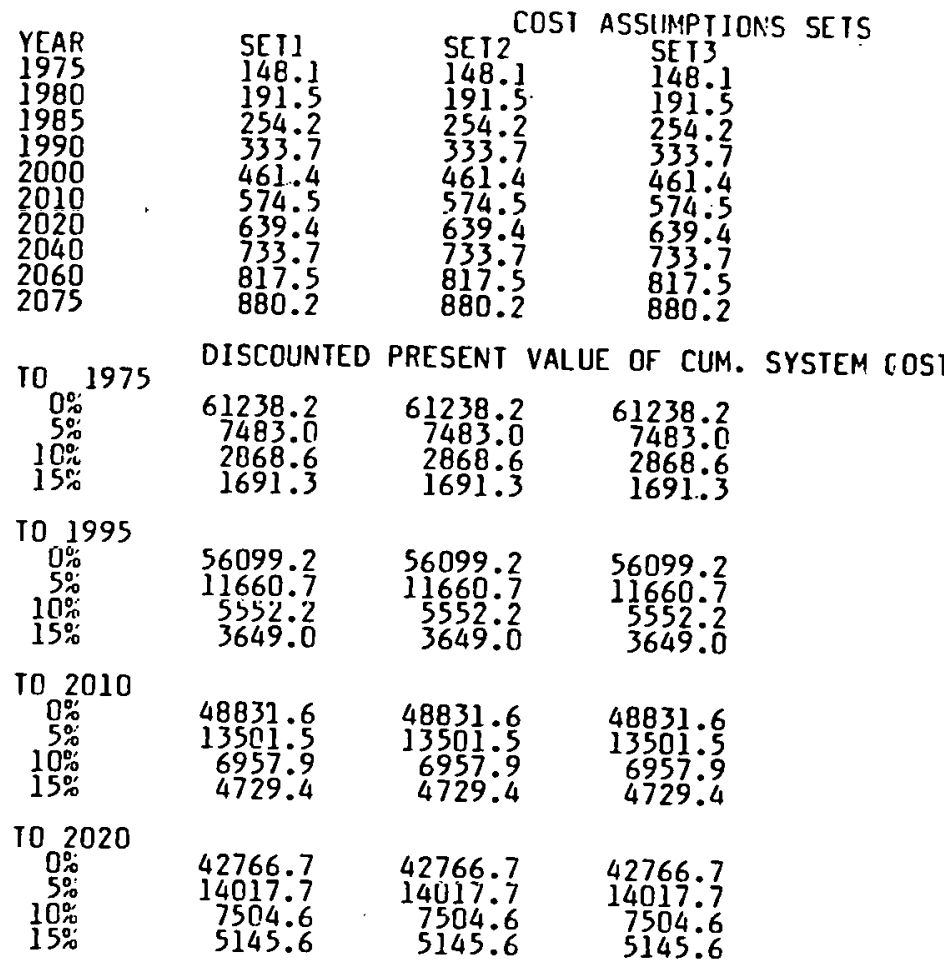

HEALTH \& ENVIRON - EMISSIONS \& EFFECTS

\begin{tabular}{|c|c|c|c|c|c|c|}
\hline $\begin{array}{l}\text { YEAR } \\
1975 \\
1980 \\
1985 \\
1990 \\
2000 \\
2010 \\
2020 \\
2040 \\
2060 \\
2075\end{array}$ & $\begin{array}{l}\text { POP EXP } \\
\text { E3 } \\
\text { MAN REM } \\
14.31 \\
46.17 \\
100.98 \\
217.62 \\
280.53 \\
329.40 \\
356.40 \\
367.20 \\
367.20 \\
367.20\end{array}$ & $\begin{array}{c}\text { KR-85 } \\
\text { E6 } \\
\text { CURIES } \\
13.04 \\
42.07 \\
92.00 \\
198.28 \\
255.59 \\
300.12 \\
324.72 \\
334.56 \\
334.56 \\
334.56\end{array}$ & $\begin{array}{r}\text { TRIT } \\
\text { E5 } \\
\text { CURIES } \\
4.66 \\
15.05 \\
32.91 \\
70.93 \\
91.43 \\
107.36 \\
116.16 \\
119.68 \\
119.68 \\
119.68\end{array}$ & $\begin{array}{c}\text { RAD WASTE } \\
\text { E3 } \\
\text { CU FT } \\
2.92 \\
9.41 \\
20.57 \\
44.33 \\
57.15 \\
67.10 \\
72.60 \\
74.80 \\
74.80 \\
74.80\end{array}$ & $\begin{array}{r}\text { SPENT } \\
\text { BLANKE } \\
\text { E3 CU F T } \\
0.00 \\
0.00 \\
0.00 \\
0.00 \\
0.00 \\
0.00 \\
0.00 \\
0.00 \\
0.00 \\
0.00\end{array}$ & $\begin{array}{l}\text { (SPARE) } \\
\\
0.00 \\
0.00 \\
0.00 \\
0.00 \\
0.00 \\
0.00 \\
0.00 \\
0.00 \\
0.00 \\
0.00\end{array}$ \\
\hline $\begin{array}{l}\text { YEAR } \\
1975 \\
1980 \\
1985 \\
1990 \\
2000 \\
2010 \\
2020 \\
2040 \\
2060 \\
2075\end{array}$ & $\begin{array}{c}\text { CO2 } \\
\text { E9 TONS } \\
5.67 \\
6.53 \\
7.73 \\
8.80 \\
9.79 \\
10.46 \\
10.79 \\
10.95 \\
10.95 \\
10.95\end{array}$ & $\begin{array}{c}\text { CO } \\
\text { E6 TONS } \\
8.32 \\
9.10 \\
10.62 \\
11.99 \\
14.25 \\
15.21 \\
15.99 \\
16.26 \\
16.26 \\
16.26\end{array}$ & $\begin{array}{c}\text { NOX } \\
\text { E6 TONS } \\
18.08 \\
21.19 \\
25.42 \\
28.80 \\
31.90 \\
34.17 \\
35.11 \\
35.59 \\
3.59 \\
35.59\end{array}$ & $\begin{array}{c}\text { SO2 } \\
\text { E6 TONS } \\
14.12 \\
16.91 \\
21.16 \\
24.56 \\
27.81 \\
30.12 \\
30.84 \\
31.15 \\
31.15 \\
31.15\end{array}$ & $\begin{array}{c}\text { PART } \\
\text { E6 TONS } \\
8.36 \\
9.96 \\
12.90 \\
16.77 \\
20.79 \\
23.49 \\
24.28 \\
24.38 \\
24.38 \\
24.38\end{array}$ & $\begin{array}{l}3.71 \\
4.04 \\
4.15 \\
4.26 \\
4.29 \\
4.29 \\
4.29\end{array}$ \\
\hline $\begin{array}{l}\text { YEAR } \\
1975 \\
1980 \\
1985 \\
1990 \\
2000 \\
2010 \\
2020 \\
2040 \\
2060 \\
2075\end{array}$ & $\begin{array}{l}\text { LAND USE } \\
\text { E6 ACRES } \\
14.17 \\
18.01 \\
22.94 \\
30.36 \\
37.86 \\
43.93 \\
45.63 \\
46.63 \\
46.64 \\
46.64\end{array}$ & $\begin{array}{c}\text { DEAIHS } \\
\text { E3 } \\
1.14 \\
1.58 \\
1.96 \\
2.36 \\
3.21 \\
3.95 \\
3.92 \\
4.02 \\
4.02 \\
4.02\end{array}$ & $\begin{array}{c}\text { INJURIES } \\
\text { E3 } \\
26.12 \\
35.51 \\
45.05 \\
57.56 \\
81.87 \\
101.89 \\
103.22 \\
105.87 \\
105.95 \\
105.95\end{array}$ & $\begin{array}{c}\text { MAN DAYS } \\
\text { LOST E6 } \\
1.71 \\
2.34 \\
2.94 \\
3.68 \\
5.16 \\
6.40 \\
6.43 \\
6.60 \\
6.60 \\
6.60\end{array}$ & $\begin{array}{c}\text { SOL ID WASTE } \\
\text { E9 TONS } \\
.20 \\
.78 \\
.36 \\
.48 \\
.60 \\
.79 \\
.75 \\
.78 \\
.78 \\
.78\end{array}$ & \\
\hline
\end{tabular}

Figure D-2. Continued. 


\begin{tabular}{|c|c|c|c|c|c|c|}
\hline $\mathrm{HZO2}$ & $\begin{array}{c}\text { IMPORTS,A } \\
\text { FOSSIL } \\
\text { TOTA }\end{array}$ & $\begin{array}{l}\text { ALLOWED, NO FUS } \\
\text { RESOURCES } \\
\text { AL USE }\end{array}$ & , NO FBR & \\
\hline $\begin{array}{l}\text { YEAR } \\
1975 \\
1980 \\
1985 \\
1990 \\
2000 \\
2010 \\
2020 \\
2040 \\
2060\end{array}$ & $\begin{array}{c}\text { LIQ \& GAS } \\
52.80 \\
58.66 \\
66.50 \\
66.80 \\
65.90 \\
63.20 \\
63.10 \\
63.10 \\
63.10 \\
63.10\end{array}$ & 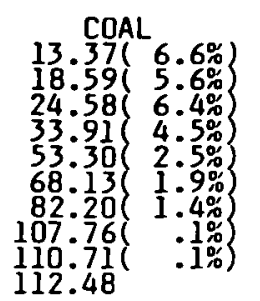 & $\begin{array}{c}\text { LIQ \& GAS } \\
6.48 \\
6.98 \\
6.70 \\
6.15 \\
5.30 \\
5.00 \\
4.71 \\
4.36 \\
4.36 \\
4.36\end{array}$ & $\begin{array}{l}\text { COAL } \\
8.82 \\
13.03 \\
14.86 \\
18.00 \\
19.14 \\
23.19 \\
33.43 \\
57.25 \\
60.11 \\
61.83\end{array}$ & $\begin{array}{r}\text { FISSION } \\
1.65 \\
5.34 \\
11.33 \\
23.97 \\
28.86 \\
31.58 \\
24.95 \\
4.33 \\
1.62 \\
.00\end{array}$ & $\begin{array}{l}\text { CIR } \\
0.00 \\
0.00 \\
0.00 \\
0.00 \\
0.00 \\
0.00\end{array}$ \\
\hline
\end{tabular}

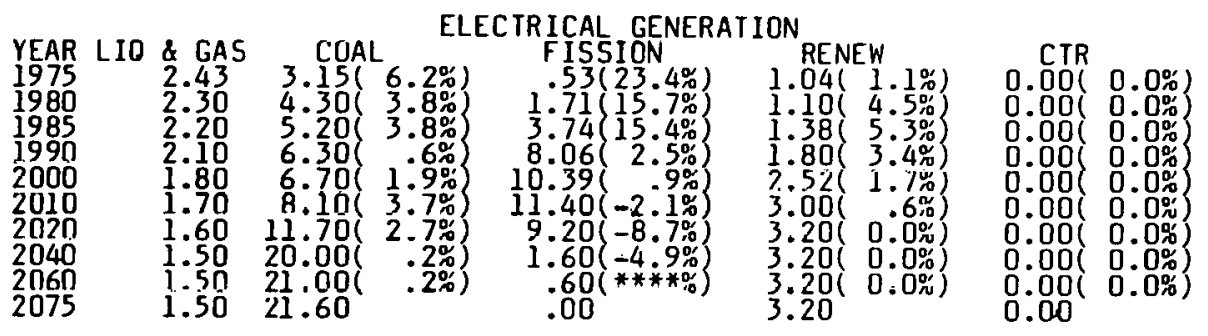

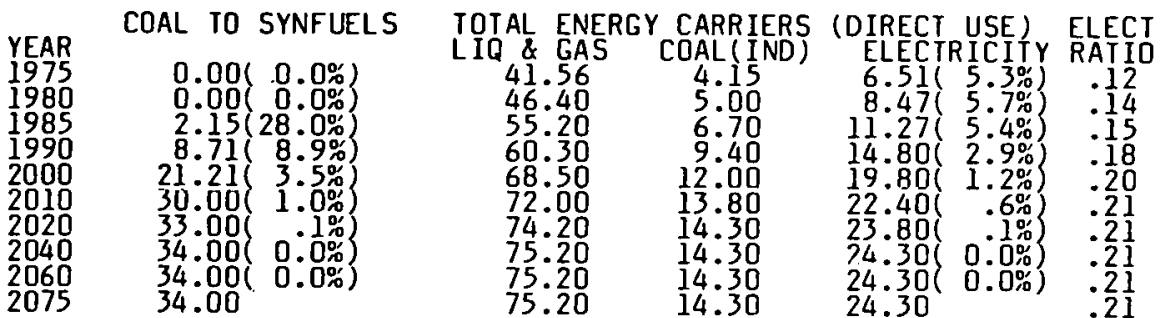

FINAL CONSUMPIION END USE

$\begin{array}{ll}\text { YEAR } & R \& 2 \\ 1975 & 13.20 \\ 1980 & 12.40 \\ 1985 & 11.50 \\ 1990 & 11.30 \\ 2000 & 11.50 \\ 2010 & 11.40 \\ 2020 & 11.40 \\ 2040 & 11.30 \\ 2060 & 11.30 \\ 2075 & 11.30\end{array}$

$\begin{array}{cc}\text { LIQ \& GAS } \\ \text { IND } \\ 9.88 & 18.45 \\ 14.00 & 20.40 \\ 20.50 & 23.20 \\ 22.00 & 26.04 \\ 26.00 & 31.00 \\ 27.70 & 32.90 \\ 28.10 & 34.70 \\ 28.60 & 35.30 \\ 28.60 & 35.30 \\ 28.60 & 35.30\end{array}$

$\begin{array}{ccr} & \\ R_{4} C^{\text {ELECTRICITY }} & \\ 3.70 & \text { IND } & \text { TRANS } \\ 4.60 & 3.71 & .02 \\ 5.70 & 5.40 & .01 \\ 7.00 & 7.40 & .17 \\ 8.80 & 10.00 & 1.40 \\ 9.90 & 11.30 & 1.00 \\ 10.30 & 12.10 & 1.40 \\ 10.40 & 12.30 & 1.60 \\ 10.40 & 12.30 & 1.60 \\ 10.40 & 12.30 & 1.60\end{array}$

TOTALS

\begin{tabular}{|c|c|c|c|c|c|}
\hline $\begin{array}{l}\text { YEAR } \\
1975 \\
1980 \\
1985 \\
1990 \\
2000 \\
2010 \\
2020 \\
2040 \\
2060 \\
2075\end{array}$ & $\begin{array}{l}R \& C \\
16.98 \\
17.00 \\
17.20 \\
18.50 \\
20.30 \\
21.30 \\
21.70 \\
21.70 \\
21.70 \\
21.70\end{array}$ & $\begin{array}{l}\text { IND } \\
16: 73 \\
22.80 \\
32.80 \\
39.60 \\
48.00 \\
52.80 \\
54.50 \\
55.20 \\
55.20 \\
55.20\end{array}$ & $\begin{array}{l}\text { IRANS } \\
18.51 \\
20.17 \\
23.37 \\
26.40 \\
32.00 \\
34.10 \\
36.10 \\
36.90 \\
36.90 \\
36.90\end{array}$ & $\begin{array}{r}\text { TOT USE } \\
52.22 \\
59.97 \\
73.37 \\
84.50 \\
100.30 \\
108.20 \\
1112.30 \\
113.80 \\
113.80 \\
113.80\end{array}$ & 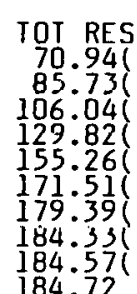 \\
\hline
\end{tabular}

\begin{tabular}{lrrr} 
& \multicolumn{2}{c}{ CUM. RESOURCE USE } \\
& $1975-2024$ & $1995-2044$ & $1975-2075$ \\
IOTAL COAL & 2523. & $4 U 42$. & 7998. \\
TOTAL LIQ \& GAS & 3176. & 3187. & 6395.
\end{tabular}

Figure D-3. Energy activity levels national annual totals (E15 Btu). 
TOTAL ANNUAL SYSTEM COST (ES DOLLARS)

\begin{tabular}{llll} 
& & \multicolumn{2}{c}{ COST ASSUMPTIONS SETS } \\
YEAR & SET1 & SET2 & SET 3 \\
1975 & 148.1 & 148.1 & 148.1 \\
1980 & 191.5 & 191.5 & 191.5 \\
1985 & 254.2 & 254.2 & 254.2 \\
1990 & 333.7 & 333.7 & 333.7 \\
2000 & 461.4 & 461.4 & 461.4 \\
2010 & 570.9 & 570.9 & 570.9 \\
2020 & 654.4 & 654.4 & 654.4 \\
2040 & 800.1 & 800.1 & 800.1 \\
2060 & 912.3 & 912.3 & 912.3 \\
2075 & 997.4 & 997.4 & 997.4
\end{tabular}

\begin{tabular}{cccc} 
& \multicolumn{3}{c}{ DISCOUNTED PRESENT VALUE OF CUM. SYSIEM COST } \\
TO 1975 & 65368.8 & 65368.8 & 65368.8 \\
$0 \%$ & 65368.8 & 7597.1 & 7597.1 \\
$5 \%$ & 7597.1 & 287.1 \\
$10 \%$ & 2874.1 & 2874.1 & 2874.1 \\
$15 \%$ & 1691.7 & 1691.7 & 1691.7
\end{tabular}

I0 1995

$\begin{array}{rrrr}\text { TO } 1995 & & & \\ 0 \% & 60228.9 & 60228.9 & 60228.9 \\ 5 \% & 11962.6 & 11962.6 & 11962.6 \\ 10 \% & 5588.5 & 5588.5 & 5588.5 \\ 15 \% & 3654.2 & 3654.2 & 3654.2\end{array}$

$\begin{array}{rrrr}\text { TO } 2010 & & & \\ 0 \% & 52981.9 & 52981.9 & 52981.9 \\ 5 \% & 14152: 3 & 14152.3 & 14152.3 \\ 10 \% & 7134.7 & 7134.7 & 7134.7 \\ 15 \% & 4796.4 & 4796.4 & 4796.4\end{array}$

$\begin{array}{crrr}\text { T0 } 2020 & & & \\ 000 & 46887.0 & 46887.0 & 46887.0 \\ 5 \% & 15047.7 & 15047.7 & 150477.7 \\ 10 \% & 7934.5 & 7934.5 & 7934.5 \\ 15 \% & 5392.5 & 5392.5 & 5392.5\end{array}$

HEALTH \& ENVIRON - EMISSIONS \& EFFECTS

\begin{tabular}{|c|c|c|c|c|c|c|}
\hline $\begin{array}{l}\text { YEAR } \\
1975 \\
1980 \\
1985 \\
1990 \\
2000 \\
2010 \\
2020 \\
2040 \\
2060 \\
2007\end{array}$ & $\begin{array}{r}\text { POP EXP } \\
\text { E3 } \\
\text { MAN REM } \\
14.31 \\
46.17 \\
100.98 \\
217.62 \\
280.53 \\
307.80 \\
248.40 \\
43.20 \\
16.20 \\
.00\end{array}$ & $\begin{array}{r}\text { KR-85 } \\
\text { E6 } \\
\text { CURIES } \\
13.04 \\
42.07 \\
92.00 \\
198.28 \\
255.59 \\
280.44 \\
226.32 \\
39.36 \\
14.76 \\
.00\end{array}$ & $\begin{array}{r}\text { TRIT } \\
\text { E5 } \\
\text { CURIES } \\
4.66 \\
15.05 \\
32.91 \\
70.93 \\
91.43 \\
100.32 \\
80.96 \\
14.08 \\
5.28 \\
.00\end{array}$ & $\begin{array}{c}\text { RAD WASTE } \\
\text { E3 } \\
\text { CUFT } \\
2.92 \\
9.41 \\
20.57 \\
44.33 \\
57.15 \\
62.70 \\
50.60 \\
8.80 \\
3.30 \\
.00\end{array}$ & $\begin{array}{c}\text { SPENT } \\
\text { BLANKET } \\
\text { E3 CU FT } \\
0.00 \\
0.00 \\
0.00 \\
0.00 \\
0.00 \\
0.00 \\
0.00 \\
0.00 \\
0.00 \\
0.00\end{array}$ & $\begin{array}{l}0 . \\
0 \\
0 \\
0 \\
0 \\
0 \\
0\end{array}$ \\
\hline
\end{tabular}

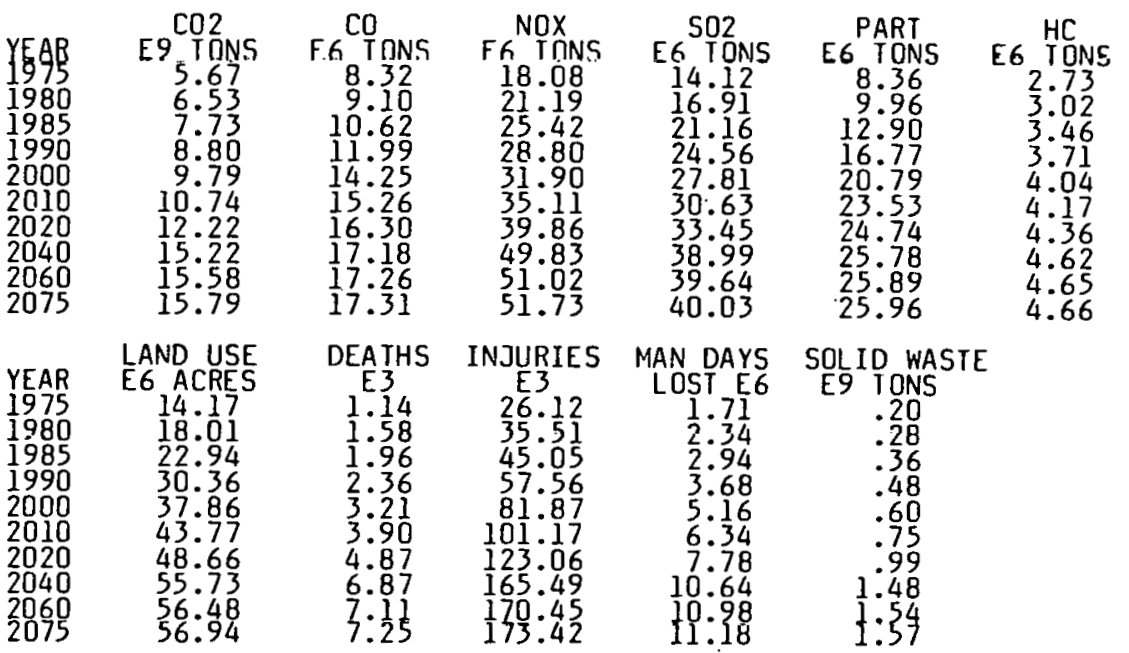

Figure D-3. Continued. 
HZO3 NO IMPORT, NO FBR, NO FUSION -- ULTRA HIGH COAL

FOSSIL RESOURCES TOTAL USE

$\begin{array}{cc}\text { YEAR } & \text { LIQ \& GAS } \\ 1975 & 52.80 \\ 1980 & 49.98 \\ 1985 & 49.45 \\ 1990 & 47.79 \\ 2000 & 41.99 \\ 2010 & 27.14 \\ 2020 & 26.11 \\ 2040 & 20.29 \\ 2060 & 20.29 \\ 2075 & 20.29\end{array}$

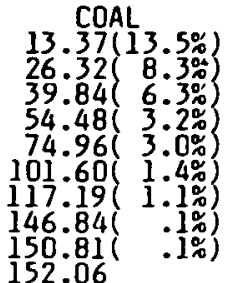

\section{)}

LIQ

$\begin{array}{lccc}\& \text { CAS } & \text { COAL } & \text { FISSION } & \text { CTR } \\ 6.48 & 8.82 & 1.65 & 0.00 \\ 6.98 & 13.03 & 5.34 & 0.00 \\ 6.70 & 14.86 & 11.33 & 0.00 \\ 6.15 & 18.00 & 23.97 & 0.00 \\ 5.30 & 19.14 & 28.86 & 0.00 \\ 5.00 & 23.19 & 31.58 & 0.00 \\ 4.71 & 33.43 & 24.95 & 0.00 \\ 4.36 & 57.25 & 4.33 & 0.00 \\ 4.36 & 60.11 & 1.62 & 0.00 \\ 4.36 & 61.83 & .00 & 0.00\end{array}$

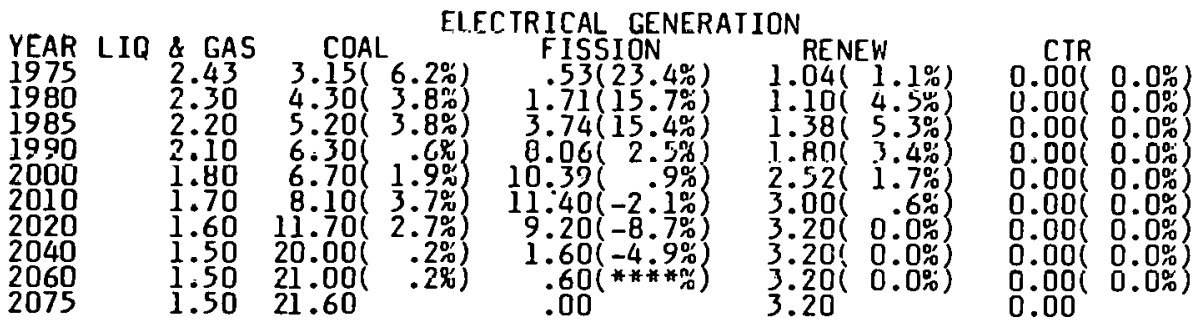

$\begin{array}{rr} & \text { COAL TO SYNFUE } \\ \text { YEAR } & \\ 1975 & 0.00(0.0 \%) \\ 1980 & 0.00(0.0 \%) \\ 1985 & 2.15(28.0 \% \\ 1990 & 8.71(8.9 \% \\ 2000 & 21.21(5.7 \% \\ 2010 & 37.69(1.8 \%) \\ 2020 & 45.31(\% \%) \\ 2040 & 52.46(\quad .3 \%) \\ 2060 & 55.54(\% 2 \%) \\ 2075 & 57.08\end{array}$

TOTAL ENERGY CARRIERS (DIRECT USE) ELECT
LIQ \& GAS COAL (IND) ELECTRICITY RATIO

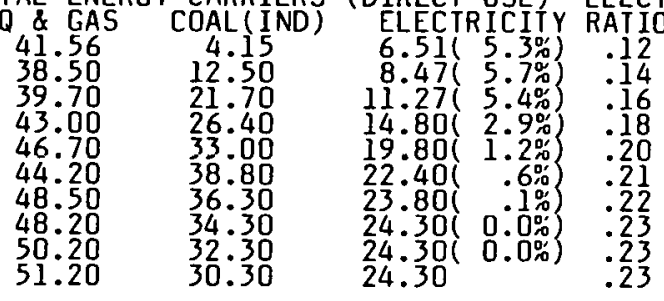

FINAL CONSUMPTION END USE

$\begin{array}{ll}\text { YEAR } & R \& \\ 1975 & 13.20 \\ 1900 & 10.2 \\ 1985 & 8.2 \\ 1990 & 8.20 \\ 2000 & 7.04 \\ 2010 & 7.00 \\ 2020 & 7.4 \\ 2040 & 7.2 \\ 2060 & 7.5 \\ 2075 & 7.6\end{array}$

LIQ \& GAS

$\begin{array}{rr}\text { IND } & \text { IRANS } \\ 19.88 & 18.49 \\ 11.62 & 16.59 \\ 14.74 & 16.69 \\ 16.26 & 18.54 \\ 17.73 & 21.13 \\ 17.00 & 20.20 \\ 10.37 & 22.68 \\ 18.33 & 22.63 \\ 19.09 & 23.56 \\ 19.47 & 24.03\end{array}$

\begin{tabular}{rrr}
\multicolumn{3}{c}{ ELECTRICITY } \\
$R_{3} C^{2}$ & IND & TRANS \\
3.78 & 2.71 & .02 \\
4.611 & 3.80 & .07 \\
5.70 & 5.40 & .17 \\
7.00 & 7.40 & .40 \\
8.80 & $10.0 U$ & 1.04 \\
9.90 & 11.30 & 1.20 \\
10.30 & 12.10 & 1.40 \\
10.40 & 12.30 & 1.60 \\
10.40 & 12.30 & 1.60 \\
10.40 & 12.30 & 1.60
\end{tabular}

TOTALS

\begin{tabular}{|c|c|c|c|c|c|}
\hline $\begin{array}{l}\text { YEAR } \\
1975 \\
1980 \\
1985 \\
1990 \\
2000 \\
2010 \\
2020 \\
2040 \\
2060 \\
2075\end{array}$ & $\begin{array}{l}R \& C \\
16.98 \\
14.89 \\
13.97 \\
15.20 \\
16.64 \\
16.90 \\
17.75 \\
17.64 \\
17.94 \\
18.09\end{array}$ & $\begin{array}{l}\text { IND } \\
16.73 \\
27.92 \\
41.84 \\
50.06 \\
60.73 \\
67.10 \\
66.77 \\
64.93 \\
63.69 \\
62.07\end{array}$ & $\begin{array}{l}\text { TRANS } \\
18.51 \\
16.66 \\
16.86 \\
18.94 \\
22.13 \\
21.40 \\
21.08 \\
24.23 \\
25.16 \\
25.63\end{array}$ & $\begin{array}{l}\text { TOT USE } \\
52.22 \\
59.47 \\
72.67 \\
84.20 \\
99.50 \\
105.40 \\
108.60 \\
106.80 \\
106.79 \\
105.79\end{array}$ & 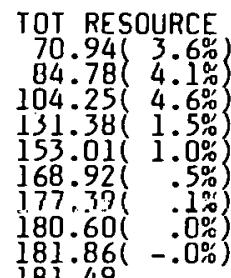 \\
\hline
\end{tabular}

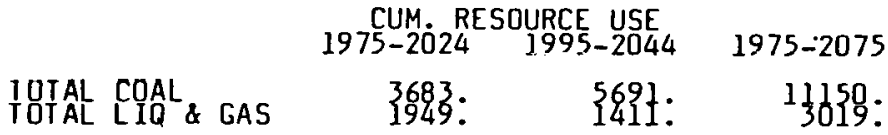

Figure D-4. Energy activity levels national annual totals (E15 Btu). 
TOTAL ANNUAL SYSIEM COST (E9 DOLLARS)

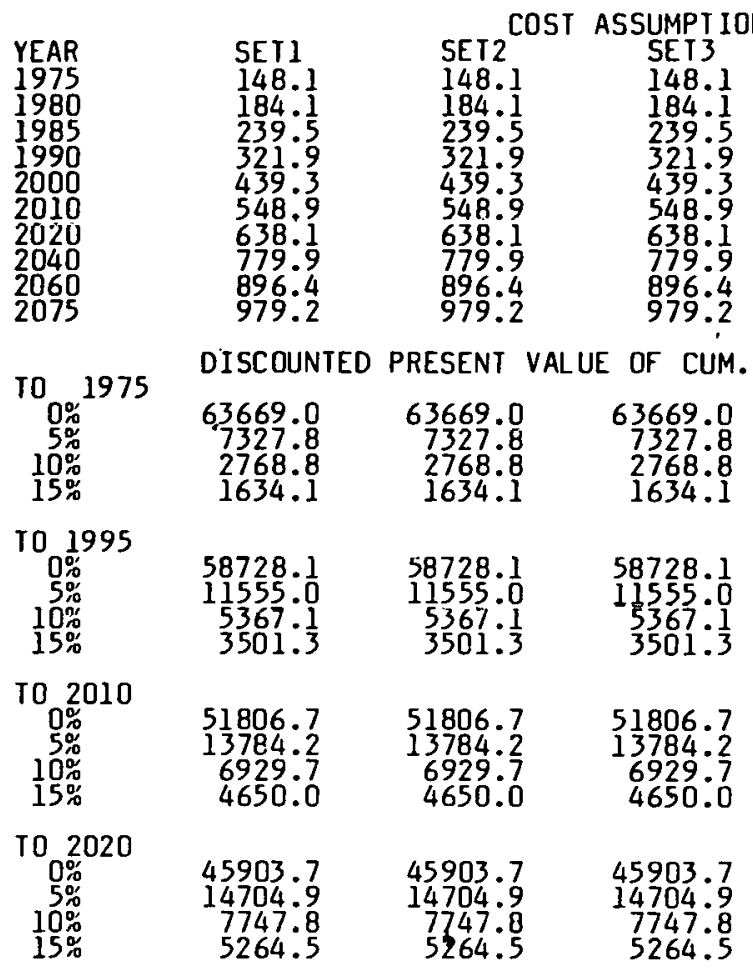

HEALTH \& ENVIRON - EMISSIONS \& EFFECTS

\begin{tabular}{|c|c|c|c|c|c|c|}
\hline $\begin{array}{l}\text { YEAR } \\
1975 \\
1980 \\
1985 \\
1990 \\
2000 \\
2010 \\
2020 \\
2040 \\
2060 \\
2075\end{array}$ & $\begin{array}{l}\text { POP EXP } \\
\text { E3 } \\
\text { MAN REM } \\
14.31 \\
46.17 \\
100.98 \\
217.62 \\
280.53 \\
307.80 \\
248.40 \\
43.20 \\
16.20 \\
.00\end{array}$ & $\begin{array}{r}\text { KR-85 } \\
\text { E6 } \\
\text { CURIES } \\
13.04 \\
42.07 \\
92.00 \\
198.28 \\
255.59 \\
280.44 \\
226.32 \\
39.36 \\
14.76 \\
.00\end{array}$ & $\begin{array}{r}\text { TRIT } \\
\text { ES } \\
\text { CURIES } \\
4.66 \\
15.05 \\
32.91 \\
70.93 \\
91.43 \\
100.32 \\
80.96 \\
14.08 \\
5.28 \\
.00\end{array}$ & $\begin{array}{c}\text { RAD WASTE } \\
\text { E3 } \\
\text { CUFT } \\
2.92 \\
9.41 \\
20.57 \\
44.33 \\
57.15 \\
62.70 \\
50.60 \\
8.80 \\
3.30 \\
.00\end{array}$ & $\begin{array}{c}\text { SPENT } \\
\text { BLANKET } \\
\text { E3 CU F } \\
0.00 \\
0.00 \\
0.00 \\
0.00 \\
0.00 \\
0.00 \\
0.00 \\
0.00 \\
0.00 \\
0.00\end{array}$ & $\begin{array}{l}0.00 \\
0.00 \\
0.00 \\
0.00 \\
0.00 \\
0.00 \\
0.00 \\
0.00 \\
0.00 \\
0.00\end{array}$ \\
\hline $\begin{array}{l}\text { YEAR } \\
1975 \\
1980 \\
1985 \\
1990 \\
2000 \\
2010 \\
2020 \\
2040 \\
2060 \\
2075\end{array}$ & $\begin{array}{c}\text { CO2 } \\
\text { E9 TONS } \\
5.67 \\
6.73 \\
8.16 \\
9.31 \\
10.39 \\
11.31 \\
12.62 \\
15.30 \\
15.59 \\
15.66\end{array}$ & $\begin{array}{c}\text { CO } \\
\text { E6 TONS } \\
0.32 \\
7.96 \\
8.47 \\
9.54 \\
10.95 \\
10.96 \\
12.19 \\
12.74 \\
13.14 \\
13.30\end{array}$ & $\begin{array}{c}\text { NOX } \\
\text { E6 TONS } \\
18.08 \\
21.54 \\
25.99 \\
29.54 \\
32.73 \\
35.87 \\
40.46 \\
49.72 \\
50.91 \\
51.32\end{array}$ & $\begin{array}{c}\text { SO2 } \\
\text { E6 TONS } \\
14.12 \\
20.05 \\
27.16 \\
31.43 \\
36.23 \\
40.39 \\
41.98 \\
46.15 \\
46.04 \\
45.45\end{array}$ & $\begin{array}{c}\text { PART } \\
\text { E6 TONS } \\
8.36 \\
18.90 \\
30.75 \\
37.07 \\
45.75 \\
53.18 \\
50.79 \\
49.27 \\
47.02 \\
44.66\end{array}$ & $\begin{array}{c}\text { HC } \\
\text { E6 T⿱一N S } \\
2.73 \\
2.75 \\
2.96 \\
3.16 \\
3.31 \\
3.08 \\
3.24 \\
3.28 \\
3.33 \\
3.33\end{array}$ \\
\hline $\begin{array}{l}\text { YEAR } \\
1975 \\
1980 \\
1905 \\
1990 \\
2000 \\
2010 \\
2020 \\
2040 \\
2060 \\
2075\end{array}$ & $\begin{array}{l}\text { LAND USE } \\
\text { E6 ACRES } \\
14.17 \\
19.34 \\
25.56 \\
34.20 \\
41.59 \\
49.36 \\
54.41 \\
61.88 \\
62.80 \\
63.07\end{array}$ & $\begin{array}{c}\text { DEA THS } \\
\text { E3 } \\
1.14 \\
2.20 \\
3.19 \\
4.02 \\
4.96 \\
6.15 \\
6.96 \\
8.93 \\
9.06 \\
9.07\end{array}$ & $\begin{array}{c}\text { INJURIES } \\
\text { E3 } \\
26.12 \\
47.64 \\
69.02 \\
89.98 \\
115.90 \\
149.10 \\
170.59 \\
215.61 \\
220.35 \\
221.54\end{array}$ & $\begin{array}{c}\text { MAN DAYS } \\
\text { LOST EO } \\
1.71 \\
3.19 \\
4.63 \\
5.95 \\
7.55 \\
9.59 \\
10.92 \\
13.87 \\
14.14 \\
14.20\end{array}$ & $\begin{array}{c}\text { SOLID WASTE } \\
\text { E9 IONS } \\
.20 \\
.29 \\
.37 \\
.50 \\
.62 \\
.83 \\
1.09 \\
1.62 \\
1.70 \\
1.74\end{array}$ & \\
\hline
\end{tabular}

Figure D-4. Continued. 
HZO4 IMPORTS ALLOWED, FUSION

\section{FOSSIL RESOURCES \\ TOTAL USE}

$\begin{array}{lc}\text { YEAR } & \text { LIQ } 8 \text { GAS } \\ 1975 & 52.80 \\ 1980 & 58.66 \\ 1985 & 66.50 \\ 1990 & 66.80 \\ 2000 & 65.90 \\ 2010 & 63.20 \\ 2020 & 63.10 \\ 2040 & 63.10 \\ 2060 & 63.10 \\ 2075 & 63.10\end{array}$

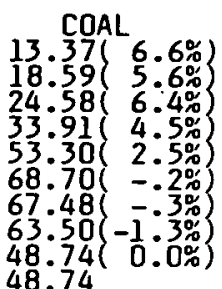

ELECTRIC GENERATION RESDURCE USE (THERMAL)

\begin{tabular}{rrrr} 
LIQ \& GAS & COAL & FISSION & \multicolumn{1}{c}{ CTR } \\
6.48 & 8.82 & 1.65 & 0.00 \\
6.98 & 13.03 & 5.34 & 0.00 \\
6.70 & 14.86 & 11.33 & 0.00 \\
6.15 & 18.00 & 23.94 & .03 \\
5.30 & 19.14 & 28.53 & .34 \\
5.00 & 20.90 & 31.58 & 2.29 \\
4.711 & 19.14 & 24.95 & 14.29 \\
4.36 & 14.31 & 4.33 & 42.86 \\
4.36 & 0.00 & 1.62 & 60.00 \\
4.36 & 0.00 & .00 & 61.71
\end{tabular}

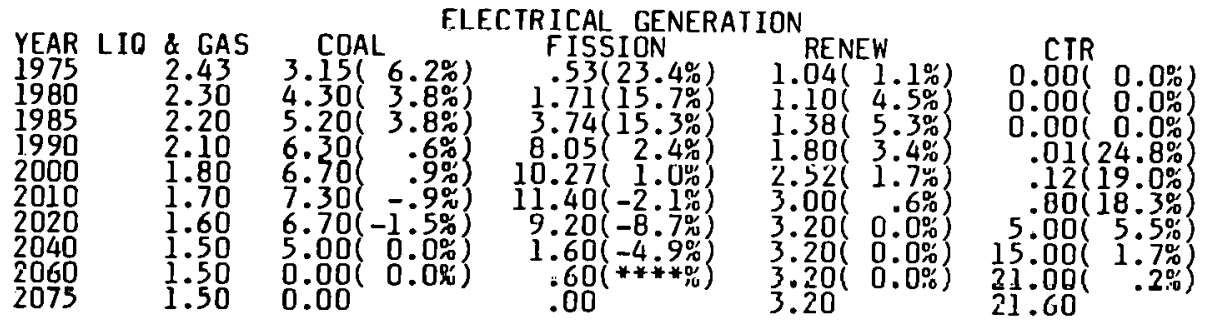

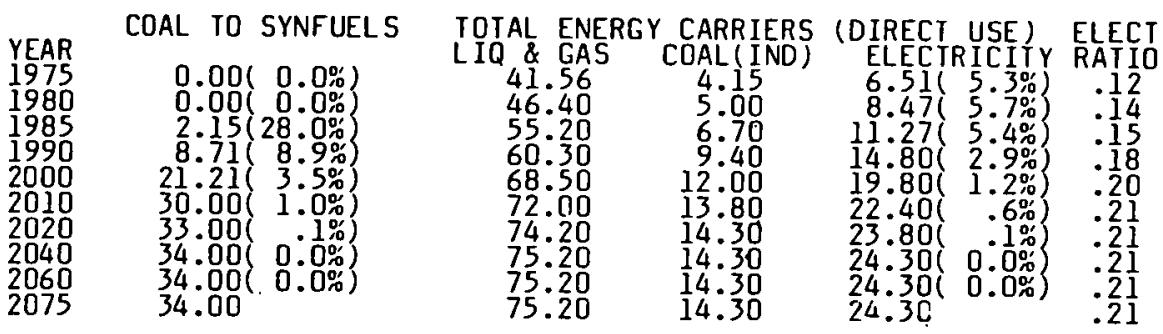

FINAL CONSUMPTION END USE

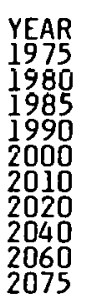

$\begin{array}{lc}R \& C & \text { LIQ \& GAS } \\ 13.20 & \text { IND } \\ 12.88 \\ 12.40 & 14.00 \\ 11.50 & 20.50 \\ 11.50 & 22.80 \\ 11.50 & 29.00 \\ 11.40 & 27.70 \\ 11.40 & 20.10 \\ 11.30 & 28.60 \\ 11.30 & 28.60 \\ 11.30 & 28.60\end{array}$

TRANS
18.49
20.00
$23 \cdot 20$
26.00
31.00
32.90
34.70
35.30
35.30
35.30

$\begin{array}{rrr} & \text { ELECTRICITY } \\ R_{2} c^{\text {ELEC }} & \text { IND } & \text { TRANS } \\ 3.70 & 2.71 & .00 \\ 4.60 & 3.00 & .07 \\ 5.70 & 5.40 & .17 \\ 7.00 & 7.40 & .40 \\ 8.80 & 10.00 & 1.00 \\ 9.90 & 11.30 & 1.20 \\ 10.30 & 12.10 & 1.40 \\ 10.40 & 12.30 & 1.60 \\ 10.40 & 12.30 & 1.60 \\ 10.40 & 12.30 & 1.60\end{array}$

TOTALS

\begin{tabular}{|c|c|c|c|c|c|}
\hline $\begin{array}{l}\text { YFAR } \\
1975 \\
1980 \\
1985 \\
1990 \\
2000 \\
2010 \\
2020 \\
2040 \\
2060 \\
2075\end{array}$ & $\begin{array}{l}R \& C \\
16.98 \\
17.00 \\
17.20 \\
18.50 \\
20.30 \\
21.30 \\
21.70 \\
21.70 \\
21.70 \\
21.70\end{array}$ & $\begin{array}{l}\text { IND } \\
16.73 \\
22.80 \\
32.80 \\
39.60 \\
48.00 \\
52.80 \\
54.50 \\
55.20 \\
55.20 \\
55.20\end{array}$ & $\begin{array}{l}\text { TRANS } \\
18.51 \\
20.17 \\
23.37 \\
26.40 \\
32.00 \\
34.10 \\
36.10 \\
36.90 \\
36.90 \\
36.90\end{array}$ & $\begin{array}{l}\text { TOT USE } \\
52.22 \\
59.97 \\
73.37 \\
84.50 \\
100.30 \\
108.20 \\
112.30 \\
113.80 \\
113.80\end{array}$ & 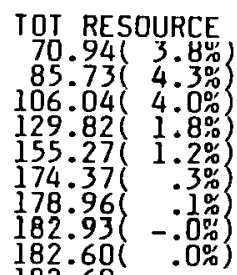 \\
\hline
\end{tabular}

\begin{tabular}{lccc} 
& \multicolumn{4}{c}{ CUM } & RESOURCE USE & \\
& $1975-2024$ & $1995-2044$ & $1975-2075$ \\
TOTAL COAL & 2386. & 3168. & 5263. \\
TOTAL LIQ \& CAS & 3176. & 3187. & 6395.
\end{tabular}

Figure D-5. Energy activity levels national annual totals (E15 Btu). 
TOTAL ANNUAL SYSTEM COST (E9 DOLLARS)

\begin{tabular}{llll} 
YEAR & & \multicolumn{2}{c}{ COST ASSUMPIIONS SEIS } \\
1975 & SEII & SET2 & SEIJ \\
1980 & 148.1 & 148.1 & 148.1 \\
1985 & 191.5 & 191.5 & 191.5 \\
1990 & 254.2 & 254.2 & 254.2 \\
2000 & 333.8 & 333.8 & 333.7 \\
2010 & 462.5 & 462.5 & 461.9 \\
2020 & 579.3 & 578.2 & 575.5 \\
2040 & 649.6 & 635.8 & 628.0 \\
2060 & 735.6 & 695.5 & 687.7 \\
2075 & 752.2 & 713.3 & 713.3
\end{tabular}

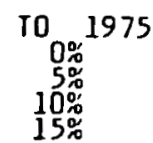

DISCOUNTED PRESENT VALUE OF CUM. SYSTEM COST

$\begin{array}{rrr}59642.4 & 57717.6 & 57408.3 \\ 7490.3 & 7417.0 & 7390.1 \\ 2873.2 & 2868.2 & 2864.7 \\ 1692.4 & 1691.9 & 1691.2\end{array}$

$\begin{array}{rrrr}T 0,1995 & & & \\ 0 \% & 54501.8 & 52577.0 & 52268.6 \\ 5 \% & 11678.1 & 11483.7 & 11413.5 \\ 10 \% & 5581.4 & 5547.6 & 5525.2 \\ 15 \% & 3664.4 & 3655.9 & 3646.2\end{array}$

TO 2010

$\begin{array}{rrrr}10 \% & 47212.0 & 45289.1 & 44992.3 \\ 0 \% & 13507.3 & 13105.3 & 12975.2 \\ 5 \% & 7037.2 & 6898.5 & 6827.5 \\ 10 \% & 4792.4 & 4725.9 & 4680.3\end{array}$

$\begin{array}{crrr}102020 & & & \\ 0 \% & 41061.3 & 39192.3 & 38951.5 \\ 5 \% & 13917.6 & 13327.8 & 13106.5 \\ 10 \% & 7569.6 & 7288.7 & 7194.2 \\ 15 \% & 5218.8 & 5045.8 & 4976.3\end{array}$

HEALTH \& ENVIRON - EMISSIONS \& EFFECTS

\begin{tabular}{|c|c|c|c|c|c|c|}
\hline $\begin{array}{l}\text { YEAR } \\
1975 \\
1980 \\
1985 \\
1990 \\
2000 \\
2010 \\
2020 \\
2040 \\
2060 \\
2075\end{array}$ & $\begin{array}{l}\text { POP EXP } \\
\text { E3 } \\
\text { MAN REM } \\
14.31 \\
46.17 \\
100.98 \\
217.62 \\
280.53 \\
329.40 \\
383.40 \\
448.20 \\
583.20 \\
583.20\end{array}$ & $\begin{array}{c}\text { KR-85 } \\
\text { E6 } \\
\text { CURIES } \\
13.04 \\
42.07 \\
92.00 \\
198.03 \\
252.64 \\
280.44 \\
226.32 \\
39.36 \\
14.76 \\
.00\end{array}$ & $\begin{array}{r}\text { TRIT } \\
\text { ES } \\
\text { CURIES } \\
4.66 \\
15.05 \\
152.91 \\
70.81 \\
90.56 \\
101.62 \\
89.11 \\
38.53 \\
39.51 \\
35.21\end{array}$ & $\begin{array}{c}\text { RAD WASTE } \\
\text { E3 } \\
\text { CUFT } \\
2.92 \\
9.41 \\
20.57 \\
44.28 \\
56.49 \\
62.70 \\
50.60 \\
8.80 \\
3.30 \\
.00\end{array}$ & $\begin{array}{r}\text { SPENT } \\
\text { BLANKET } \\
\text { E3 CU FT } \\
0.00 \\
0.00 \\
0.00 \\
.55 \\
6.60 \\
44.00 \\
275.00 \\
825.00 \\
1155.00 \\
1188.00\end{array}$ & $\begin{array}{l}0.00 \\
0.00 \\
0.00 \\
0.00 \\
0.00 \\
0.00 \\
0.00 \\
0.00 \\
0.00\end{array}$ \\
\hline
\end{tabular}

\begin{tabular}{|c|c|c|c|c|c|}
\hline $\begin{array}{l}\text { EAR } \\
975 \\
980 \\
985 \\
990 \\
000 \\
010 \\
020 \\
040 \\
060\end{array}$ & $\begin{array}{c}\text { CO2 } \\
\text { E9 TONS } \\
5.67 \\
6.53 \\
7.73 \\
8.80 \\
9.79 \\
10.46 \\
10.44 \\
9.88 \\
8.10 \\
8.10\end{array}$ & $\begin{array}{c}\text { EO } \\
\text { TONS } \\
8.32 \\
9.10 \\
10.62 \\
11.99 \\
14.25 \\
15.21 \\
15.91 \\
16.03 \\
15.65 \\
15.65\end{array}$ & $\begin{array}{c}\text { NOX } \\
\text { E6 TONS } \\
18.08 \\
21.19 \\
25.42 \\
28.80 \\
31.90 \\
34.17 \\
33.92 \\
32.01 \\
26.07 \\
26.07\end{array}$ & $\begin{array}{c}\text { S02 } \\
\text { E6TONS } \\
14.12 \\
16.91 \\
21.16 \\
24.56 \\
27.81 \\
30.12 \\
30.19 \\
29.19 \\
25.93 \\
25.93\end{array}$ & $\begin{array}{c}\text { PART } \\
\text { E6 TONS } \\
8.36 \\
9.96 \\
12.90 \\
16.77 \\
20.79 \\
23.49 \\
24.16 \\
24.03 \\
23.44 \\
23.44\end{array}$ \\
\hline $\begin{array}{l}\text { AR } \\
75 \\
80 \\
85\end{array}$ & $\begin{array}{l}\text { LAND USE } \\
\text { E6 ACRES } \\
14.17 \\
18.01 \\
22.94 \\
30.36 \\
37.86 \\
43.93 \\
44.88 \\
44.37 \\
40.58 \\
40.58\end{array}$ & $\begin{array}{c}\text { DEATHS } \\
\text { E } 3 \\
1.14 \\
1.58 \\
1.96 \\
2.36 \\
3.21 \\
3.95 \\
3.65 \\
3.22 \\
1.99 \\
1.99\end{array}$ & $\begin{array}{c}\text { INJURIES } \\
\text { E3 } \\
26.12 \\
35.51 \\
45.05 \\
57.56 \\
81.85 \\
101.75 \\
97.40 \\
88.33 \\
62.41 \\
62.30\end{array}$ & $\begin{array}{c}\text { MAN DAYS } \\
\text { LOST E6 } \\
1.71 \\
2: 34 \\
2.94 \\
3.68 \\
5.15 \\
6.39 \\
6.04 \\
5.43 \\
3.68 \\
3.69\end{array}$ & $\begin{array}{c}\text { SOLIN WASTI } \\
\text { ES TONS } \\
.20 \\
.28 \\
.36 \\
.48 \\
.60 \\
.71 \\
.68 \\
.56 \\
.24 \\
.24\end{array}$ \\
\hline
\end{tabular}

Figure D-5. Continued. 
HZOS NO IMPORTS, NO FBR, FUSION

$$
\text { FOSSIL RESOURCES }
$$

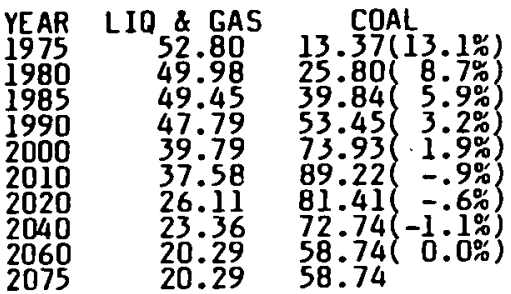

ELECTRIC GENERATION RESOURCE USE (THERMAL)

\begin{tabular}{lrrr} 
LIO 8 GAS & COAL & \multicolumn{1}{c}{ FISSION } & CTR \\
6.48 & 8.82 & 1.65 & 0.00 \\
6.98 & 13.03 & 5.34 & 0.00 \\
6.70 & 14.86 & 11.33 & 0.00 \\
6.15 & 18.00 & 23.94 & .03 \\
5.30 & 19.14 & 28.53 & .034 \\
5.00 & 20.90 & 31.58 & 8.00 \\
4.71 & 19.14 & 24.95 & 37.14 \\
4.36 & 14.31 & 4.33 & 74.29 \\
4.36 & 0.00 & 1.62 & 95.14 \\
4.36 & 0.00 & .00 & 96.86
\end{tabular}

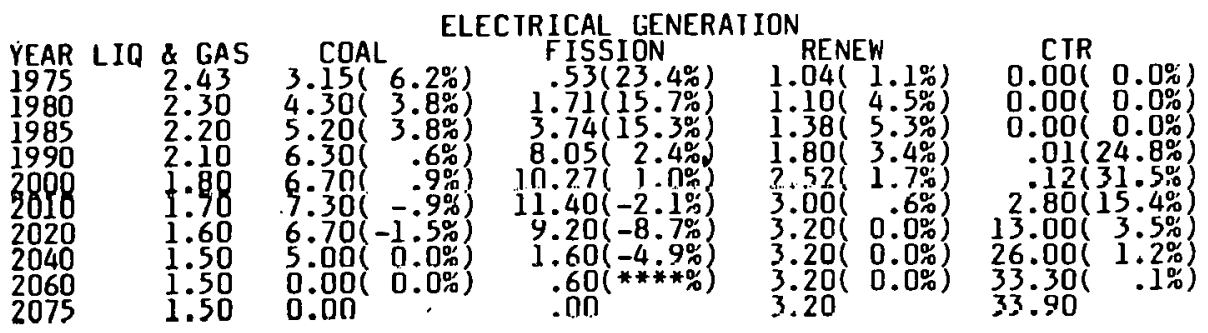

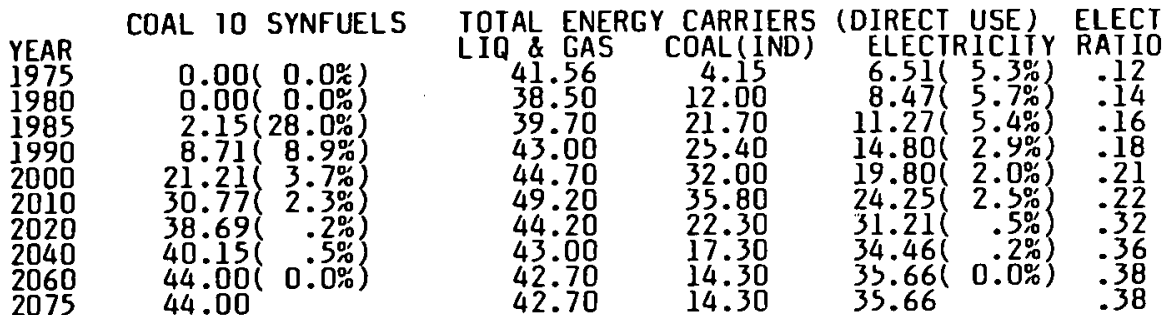

FINAL CONSUMPTION END USE

$\begin{array}{llcl} & & \text { LIQ } \& \text { GAS } \\ \text { YEAR } & \text { R\& } \& \text { LIRANS } & \text { IND } & \text { TRANS } \\ 1975 & 13.20 & 9.8 B & 18.49 \\ 1980 & 10.29 & 11.62 & 16.59 \\ 1985 & 8.27 & 14.74 & 16.69 \\ 1990 & 8.20 & 16.26 & 18.54 \\ 2000 & 7.50 & 16.97 & 20.23 \\ 7010 & 7.79 & 18.92 & 22.49 \\ 2020 & 6.79 & 16.74 & 20.67 \\ 2040 & 6.44 & 16.35 & 20.18 \\ 2060 & 6.42 & 16.24 & 20.04 \\ 2075 & 6.42 & 16.24 & 20.04\end{array}$

$\begin{array}{rrr} & \\ R \text { ELECTRICITY } & \\ 3.78 & \text { IND } & \text { TRANS } \\ 4.60 & 3.71 & .02 \\ 5.70 & 5.80 & .07 \\ 7.00 & 7.40 & .17 \\ 8.80 & 10.00 & 1.00 \\ 10.72 & 12.23 & 1.00 \\ 13.51 & 15.87 & 1.80 \\ 14.75 & 17.44 & 2.27 \\ 15.26 & 18.05 & 2.35 \\ 15.26 & 18.05 & 2.35\end{array}$

IOTALS

\begin{tabular}{|c|c|c|c|c|c|}
\hline $\begin{array}{l}\text { YEAR } \\
1975 \\
1980 \\
1985 \\
1990 \\
2000 \\
2010 \\
2020 \\
2040 \\
2060\end{array}$ & $\begin{array}{l}R \& \text { \& } \\
16.98 \\
14.89 \\
13.97 \\
15.20 \\
16.30 \\
18.51 \\
20.30 \\
21.21 \\
21.68\end{array}$ & $\begin{array}{l}\text { IND } \\
16.73 \\
27.42 \\
41.84 \\
49.06 \\
58.97 \\
66.95 \\
54.91 \\
51.10 \\
48.59\end{array}$ & $\begin{array}{l}\text { IRANS } \\
18.51 \\
16.66 \\
16.86 \\
18.94 \\
21.23 \\
23.79 \\
22.51 \\
22.45 \\
22.39\end{array}$ & $\begin{array}{r}\text { TnT USE } \\
52.22 \\
38.97 \\
72.67 \\
83.20 \\
96.50 \\
109.25 \\
97.72 \\
94.76 \\
92.66 \\
97.66\end{array}$ & $\begin{array}{r}\text { TOT RESO } \\
70.94 \\
84.26 \\
104.25 \\
130.35 \\
149.79 \\
174.98 \\
178.75 \\
183.86 \\
1140.93 \\
185\end{array}$ \\
\hline
\end{tabular}

\begin{tabular}{lrrr} 
& \multicolumn{2}{c}{ CUM. RESOURCE USE } \\
& $1975-2024$ & $1995-2044$ & $1975-2075$ \\
IOIAL COAL & 3194. & 3917. & $65734:$
\end{tabular}

Figure D-6. Energy actiyity levels national annual totals (E15 Btu). 
TOTAL ANNUAL SYSTEM COST (E9 DOLLARS)

\begin{tabular}{|c|c|c|c|}
\hline $\begin{array}{l}\text { YEAR } \\
1975 \\
1980 \\
1985 \\
1990 \\
2000 \\
2010 \\
2020 \\
2040 \\
2060 \\
2075\end{array}$ & $\begin{array}{l}\text { SET1 } \\
148.1 \\
183.4 \\
239.5 \\
320.4 \\
432.7 \\
579.3 \\
664.2 \\
728.2 \\
713.3 \\
709.8\end{array}$ & $\begin{array}{l}\text { SE12 COST A } \\
148.1 \\
183.4 \\
239.5 \\
320.4 \\
432.7 \\
575.4 \\
628.4 \\
658.7 \\
651.6 \\
686.4\end{array}$ & $\begin{array}{l}\text { ASSUMPIIINS SE IS } \\
\text { SET } 31 \\
148.1 \\
183.4 \\
239.5 \\
320.4 \\
432.1 \\
566.2 \\
608.0 \\
645.1 \\
651.6 \\
686.4\end{array}$ \\
\hline $\begin{array}{c}\mathrm{F} 0_{0 \%} 1975 \\
5 \% \\
10 \% \\
15 \% \\
15 \%\end{array}$ & $\begin{array}{l}\text { DISCOUNTED } \\
58035.0 \\
7275.8 \\
2768.0 \\
1630.8\end{array}$ & $\begin{array}{l}\text { PRESENT VALUE } \\
54626.9 \\
7129.1 \\
2756.7 \\
1629.5\end{array}$ & $\begin{array}{l}\text { UF CUM. SYSIEM COST } \\
53943.4 \\
7065.3 \\
2748.3 \\
1.628 .1\end{array}$ \\
\hline $\begin{array}{c}\text { T0 } 1995 \\
0 \% \\
5 \% \\
5 \% \\
10 \% \\
15 \%\end{array}$ & $\begin{array}{r}53116.6 \\
11446.1 \\
5402.8 \\
3508.9\end{array}$ & $\begin{array}{r}49708.5 \\
11057.3 \\
5326.4 \\
3487.7\end{array}$ & $\begin{array}{r}49025.4 \\
10888.6 \\
5271.1 \\
3465.1\end{array}$ \\
\hline $\begin{array}{c}102010 \\
0 \% \\
5 \% \\
10 \% \\
15 \% \\
15 \%\end{array}$ & $\begin{array}{r}46158.4 \\
13549.7 \\
7127.5 \\
4864.6\end{array}$ & $\begin{array}{r}42757.6 \\
12749.6 \\
6817.5 \\
4702.3\end{array}$ & $\begin{array}{r}42105.7 \\
12436.9 \\
6633.5 \\
4577.5\end{array}$ \\
\hline $\begin{array}{c}\text { T0 } 2020 \\
0 \% \\
5 \% \\
10 \% \\
15 \%\end{array}$ & $\begin{array}{r}39889.1 \\
13840.0 \\
7622.0 \\
5285.3\end{array}$ & $\begin{array}{r}36642.3 \\
12724.0 \\
7 n 47.2 \\
4910.6\end{array}$ & $\begin{array}{r}36154.7 \\
12424.4 \\
6839.0 \\
4752.6\end{array}$ \\
\hline
\end{tabular}

HEALTH \& ENVIRON - EMISSIONS \& EFFECIS

\begin{tabular}{|c|c|c|c|c|c|c|}
\hline $\begin{array}{l}\text { YEAR } \\
1975 \\
1980 \\
1985 \\
1990 \\
2000 \\
2010 \\
2020 \\
2040 \\
2060\end{array}$ & $\begin{array}{l}\text { POP EXP } \\
\text { E3 } \\
\text { MAN REM } \\
14.31 \\
46.17 \\
100.98 \\
217.62 \\
280.53 \\
383.40 \\
599.40 \\
745.20 \\
915.30 \\
915.30\end{array}$ & $\begin{array}{c}\text { KR-85 } \\
\text { E6 } \\
\text { CURIES } \\
13.04 \\
42.07 \\
92.00 \\
198.03 \\
252.64 \\
280.44 \\
226.32 \\
39.36 \\
14.76 \\
.00\end{array}$ & $\begin{array}{r}\text { TRIT } \\
\text { ES } \\
\text { CURIES } \\
4.66 \\
15.05 \\
32.91 \\
70.86 \\
90.57 \\
104.88 \\
102.15 \\
56.46 \\
59.56 \\
55.26\end{array}$ & $\begin{array}{c}\text { RAD WASTE } \\
\text { E3 } \\
\text { CU FT } \\
2.92 \\
9.41 \\
20.57 \\
44.28 \\
56.49 \\
62.70 \\
50.60 \\
8.80 \\
3.30 \\
.00\end{array}$ & $\begin{array}{r}\text { SPENT } \\
\text { BLANKET } \\
\text { E3 CUU FI } \\
0.00 \\
0.00 \\
0.00 \\
.55 \\
6.60 \\
154.00 \\
715.00 \\
1430.00 \\
1831.50 \\
1864.50\end{array}$ & $\begin{array}{l}0.00 \\
0.00 \\
0.00 \\
0.00 \\
0.00 \\
0.00 \\
0.00 \\
0.00 \\
0.00 \\
0.00\end{array}$ \\
\hline $\begin{array}{l}\text { YEAR } \\
1975 \\
1980 \\
1985 \\
1990 \\
2000 \\
2010 \\
2020 \\
2040 \\
2060\end{array}$ & $\begin{array}{c}\text { CO2 } \\
\text { E9 TONS } \\
5.67 \\
6.68 \\
8.16 \\
9.20 \\
10.12 \\
11.09 \\
8.92 \\
7.63 \\
5.49 \\
5.49\end{array}$ & $\begin{array}{c}\text { CO } \\
\text { E6 TONS } \\
8.32 \\
7.94 \\
8.47 \\
9.50 \\
10.53 \\
11.72 \\
10.34 \\
9.79 \\
9.24 \\
9.24\end{array}$ & $\begin{array}{c}\text { NOX } \\
\text { E6 IONS } \\
18.08 \\
21.39 \\
25.99 \\
29.25 \\
31.94 \\
35.05 \\
29.13 \\
25.22 \\
18.44 \\
18.44\end{array}$ & $\begin{array}{c}\text { SO2 } \\
\text { E6 TONS } \\
14.12 \\
19.75 \\
27.16 \\
30.82 \\
35.22 \\
38.92 \\
29.25 \\
24.79 \\
19.72 \\
19.72\end{array}$ & $\begin{array}{c}\text { PART } \\
\text { E6 TONS } \\
8.36 \\
18.27 \\
30.75 \\
35.81 \\
44.36 \\
49.59 \\
32.26 \\
25.69 \\
21.34 \\
21.34\end{array}$ & $\begin{array}{c}\text { HC } \\
\text { TONS } \\
2.73 \\
2.74 \\
2.96 \\
3.14 \\
3.18 \\
3.37 \\
2.67 \\
2.41 \\
2.13 \\
2.13\end{array}$ \\
\hline $\begin{array}{l}\text { YEAR } \\
1975 \\
1980 \\
1985 \\
1990 \\
2000 \\
2010 \\
2020 \\
2040\end{array}$ & $\begin{array}{c}\text { LAND USE } \\
\text { E6 ACRES } \\
14.17 \\
19.20 \\
25.56 \\
33.93 \\
41.15 \\
48.98 \\
52.49 \\
53.18 \\
50.38 \\
50.38\end{array}$ & $\begin{array}{c}\text { DEATHS } \\
\text { E3 } \\
1.14 \\
2.16 \\
3.19 \\
3.94 \\
4.87 \\
5.56 \\
4.43 \\
3.58 \\
2.19 \\
2.18\end{array}$ & $\begin{array}{c}\text { INJURIES } \\
\text { E3 } \\
26.12 \\
46.80 \\
69.02 \\
88.30 \\
114.09 \\
133.48 \\
114.86 \\
97.79 \\
70.63 \\
70.52\end{array}$ & $\begin{array}{c}\text { MAN DAYS } \\
\text { LOST E6 } \\
1.71 \\
3.13 \\
4.63 \\
5.84 \\
7.43 \\
8.61 \\
7.20 \\
6.02 \\
4.13 \\
4.12\end{array}$ & $\begin{array}{c}\text { SOLIU WASTE } \\
\text { E9 IONS } \\
.20 \\
.29 \\
.37 \\
.50 \\
.62 \\
.73 \\
.72 \\
.60 \\
.31 \\
.31\end{array}$ & \\
\hline
\end{tabular}

Figure D-6, Continued. 
DRASTIC LIMITS--UNREALISIIC NEAR-TERM TOI • CONSUMPIION

$$
\begin{aligned}
& \text { FOSSIL RESUURCES } \\
& \text { TOTAL USE }
\end{aligned}
$$
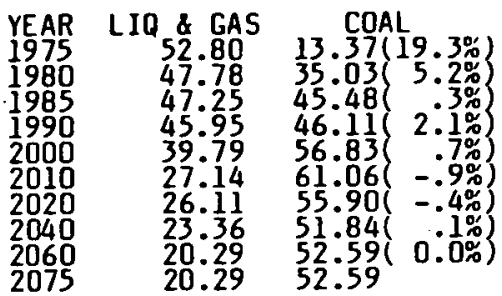

\section{ELECTRICAL GENERATION}
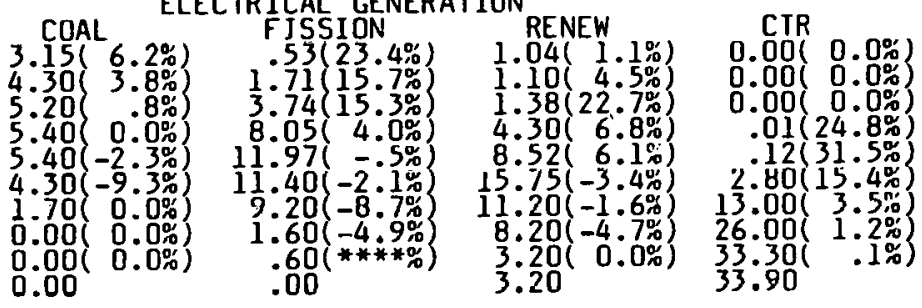

COAL TO SYNFUELS
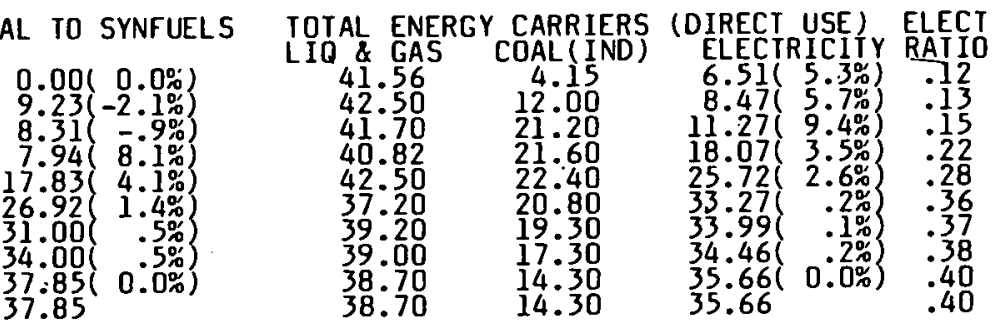

FINAL CONSUMPTION END USE

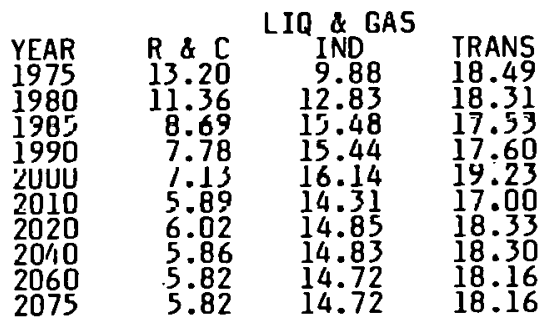

\begin{tabular}{rrr}
\multicolumn{3}{c}{ ELECTHICITY } \\
$R_{3}$ ELE & IND & TRANS \\
3.78 & 2.71 & .02 \\
4.60 & 3.80 & .07 \\
5.70 & 5.40 & .17 \\
8.54 & 9.84 & .49 \\
11.43 & 12.99 & 1.30 \\
14.71 & 16.78 & 1.78 \\
14.71 & 17.28 & 2.00 \\
14.75 & 17.44 & 2.27 \\
15.26 & 18.05 & 2.35 \\
15.26 & 18.05 & 2.35
\end{tabular}

TOTALS

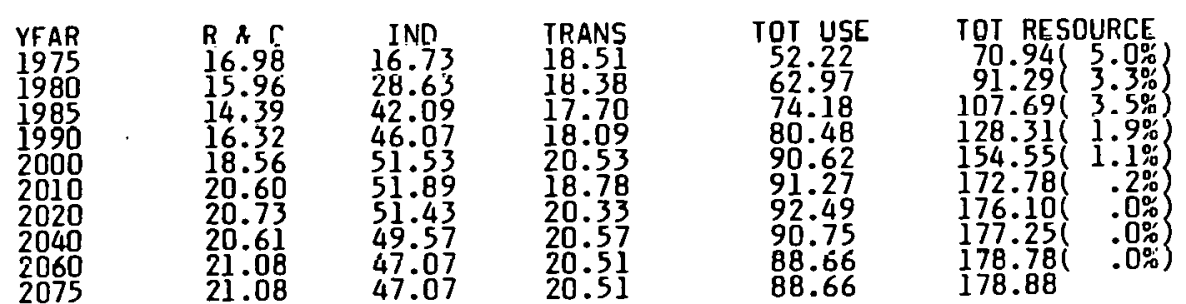

\begin{tabular}{cccc} 
& \multicolumn{4}{c}{ CUM } & RESOURCE USE & \\
& $1975-2024$ & $1995-2044$ & $1975-2075$ \\
TOIAL COAL \& GAS & 2509. & 2774. & 5181. \\
TOTAL LIO \& GS & 1890. & 1432. & 3022.
\end{tabular}

Figure D-7. Energy activity levels national annual totals (E15 Btu). 
TOTAL ANNUAL SYSTEM COST (E9 DOLLARS)

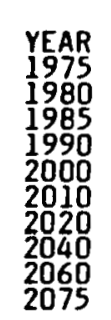

To 1975

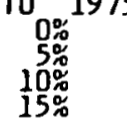

TO 1995

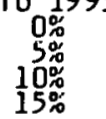

TO 2010

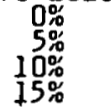

102020

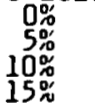

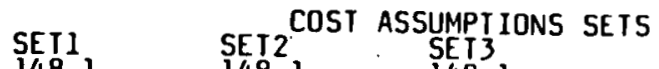

148.1 148.1

204.1204 .1204 .1

$319.6 \quad 319.3 \quad 251.6$

$469.9 \quad 369.3 \quad 319.2$

$663.5 \quad 659.6 \quad 650.4$

$687.7 \quad 651.8 \quad 631.4$

$\begin{array}{lll}706.2 & 636.8 & 623.2 \\ 681.8 & 620.2 & 620.2\end{array}$

$\begin{array}{lll}675.6 & 652.2 & 620.2 \\ \end{array}$

DISCOUNTED PRESENT VALUE OF CUM. SYSTEM IOST

$\begin{array}{rrr}58327.9 & 54919.8 & 54236.3 \\ 7651.7 & 7505.2 & 7441.4 \\ 2931.2 & 2919.8 & 2911.5 \\ 1725.9 & 1724.6 & 1723.2\end{array}$

\section{$53222.1 \quad 49814.0 \quad 49130.9$ \\ $\begin{array}{rrr}12088.9 & 11700.1 & 11531.4 \\ 5826.5 & 5750.0 & 5694.7 \\ 3791.9 & 3770.6 & 3748.9\end{array}$}

$\begin{array}{rrr}45554.4 & 42153.6 & 41501.7 \\ 13916.9 & 13116.8 & 12804.1 \\ 7546.3 & 7236.3 & 7052.2 \\ 5248.7 & 5086.4 & 4961.6\end{array}$

$\begin{array}{rrr} & & \\ 38697.3 & 35450.6 & 34962.9 \\ 13628.7 & 12512.8 & 122.13 .1 \\ 7593.1 & 7018.2 & 6810.0 \\ 5305.1 & 4930.3 & 4772.4\end{array}$

HEALTH \& ENVIRON - EMISSIONS \& EFFECTS

\begin{tabular}{|c|c|c|c|c|c|c|}
\hline $\begin{array}{l}\text { YEAR } \\
1975 \\
1980 \\
1985 \\
1990 \\
2000 \\
2010 \\
2020 \\
2040 \\
2060 \\
2040\end{array}$ & $\begin{array}{r}\text { POP EXP } \\
\text { E3 } \\
\text { MANEM } \\
14.31 \\
46.17 \\
100.98 \\
217.62 \\
326.43 \\
383.40 \\
599.40 \\
745.20 \\
915.30 \\
915.30\end{array}$ & $\begin{array}{r}\text { KR-85 } \\
\text { E6 } \\
\text { CURS } \\
13.04 \\
42.07 \\
92.00 \\
198.03 \\
294.46 \\
280.44 \\
226.32 \\
39.36 \\
14.76 \\
.00\end{array}$ & $\begin{array}{r}\text { TRIT } \\
\text { ES } \\
\text { CURIES } \\
4.66 \\
15.05 \\
32.91 \\
70.86 \\
105.53 \\
104.88 \\
102.15 \\
56.46 \\
59.56 \\
55.26 \\
1\end{array}$ & $\begin{array}{c}\text { RAD WASTE } \\
\text { E3 } \\
\text { CU FT } \\
2.92 \\
9.41 \\
20.57 \\
44.28 \\
65.84 \\
62.70 \\
50.60 \\
8.80 \\
3.30 \\
.00\end{array}$ & $\begin{array}{r}\text { SPENT } \\
\text { BLANKET } \\
\text { E3 CUFF } \\
0.00 \\
0.00 \\
0.00 \\
.55 \\
6.60 \\
154.00 \\
715.00 \\
1430.00 \\
1831.50 \\
1864.50\end{array}$ & $\begin{array}{l}0.00 \\
0.00 \\
0.00 \\
0.00 \\
0.00 \\
0.00 \\
0.00 \\
0.00 \\
0.00 \\
0.00\end{array}$ \\
\hline $\begin{array}{l}9 A R \\
975 \\
900 \\
985 \\
990 \\
000 \\
010 \\
020 \\
040\end{array}$ & $\begin{array}{c}\text { CO2 } \\
\text { E9 TONS } \\
5.67 \\
7.00 \\
8.26 \\
8.27 \\
8.40 \\
7.37 \\
6.40 \\
5.53 \\
5.17 \\
5.17\end{array}$ & $\begin{array}{c}\text { CO } \\
\text { E6 TONS } \\
8.332 \\
8.71 \\
8.83 \\
8.87 \\
9.59 \\
8.52 \\
8.81 \\
8.59 \\
8.42 \\
8.42\end{array}$ & $\begin{array}{c}\text { NOX! } \\
\text { E6 TONS } \\
18.08 \\
22.63 \\
26.54 \\
26.49 \\
26.92 \\
23.98 \\
20.83 \\
18.10 \\
17.27 \\
17.27\end{array}$ & $\begin{array}{c}\text { SO2 } \\
\text { E6 TONS } \\
14.12 \\
10.64 \\
27.38 \\
27.48 \\
28.05 \\
25.40 \\
23.04 \\
20.62 \\
18.82 \\
18.82\end{array}$ & $\begin{array}{c}\text { PART } \\
\text { E6 TONS } \\
\text { R. 36 } \\
18: 59 \\
30.30 \\
30.78 \\
31.97 \\
29.54 \\
27.51 \\
24.79 \\
21.03 \\
21.03\end{array}$ & $\begin{array}{l}\text { EC }{ }^{H C} \\
2.735 \\
2.81 \\
2.96 \\
2.92 \\
2.87 \\
2.37 \\
2.31 \\
2.15 \\
2.01 \\
2.01\end{array}$ \\
\hline $\begin{array}{l}178 \\
199 \\
2000 \\
2010 \\
2020 \\
2040\end{array}$ & $\begin{array}{l}\text { LAND USE } \\
\text { E6 ACRES } \\
14.17 \\
21.12 \\
26.65 \\
33.18 \\
43.59 \\
51.94 \\
50.26 \\
48.90 \\
48.98 \\
48.98\end{array}$ & $\begin{array}{l}\text { DEAIHS } \\
\text { E3 } \\
1.14 \\
2.36 \\
3.26 \\
3.38 \\
3.69 \\
3.48 \\
2.79 \\
2.23 \\
2.05 \\
2.05\end{array}$ & $\begin{array}{c}\text { INJURIES } \\
\text { E3 } \\
26.12 \\
56.06 \\
74.32 \\
76.42 \\
88.22 \\
88.42 \\
76.26 \\
65.75 \\
64.39 \\
64.28\end{array}$ & $\begin{array}{c}\text { MAN DAYS } \\
\text { LOST E6 } \\
1.71 \\
3.63 \\
4.00 \\
5.04 \\
5.69 \\
5.58 \\
4.70 \\
3.95 \\
3.79 \\
3.79\end{array}$ & $\begin{array}{c}\text { SOLID WASTE } \\
\text { E9 TONS } \\
.20 \\
.35 \\
.41 \\
.44 \\
.52 \\
.50 \\
.36 \\
.25 \\
.23 \\
.23\end{array}$ & \\
\hline
\end{tabular}

Figure D-7. Continued. 
ACCEL. FUSION (IMPORTS ALLOWED)

BASED ON HZO4

FOSSIL RESOURCES
TOTAL USE

$\begin{array}{cc}\text { YEAR } & \text { LIO } 8 \text { GAS } \\ 1975 & 52.80 \\ 1980 & 58.66 \\ 1985 & 66.50 \\ 1990 & 66.80 \\ 2000 & 65.90 \\ 2010 & 63.20 \\ 2020 & 63.10 \\ 2040 & 63.10 \\ 2060 & 63.10 \\ 2075 & 63.10\end{array}$

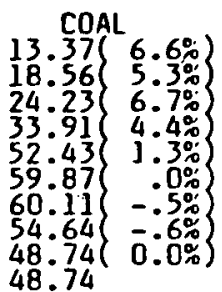
ELECIRIC GENERATION RESOURCE USE (THERMAL)

\begin{tabular}{crrr} 
LIO \& GAS & COAL & FISSION & \multicolumn{1}{c}{ CTR } \\
6.48 & 8.82 & 1.65 & 0.00 \\
6.98 & 13.00 & 5.34 & .03 \\
6.70 & 14.72 & 11.33 & .14 \\
6.15 & 18.00 & 23.61 & .34 \\
5.30 & 18.28 & 27.42 & 2.34 \\
5.00 & 15.17 & 25.49 & 14.29 \\
4.71 & 12.00 & 18.17 & 28.57 \\
4.36 & 5.72 & 1.62 & 54.29 \\
4.36 & 0.00 & 0.00 & 61.71 \\
4.36 & 0.00 & .00 & 61.71
\end{tabular}

\section{ELECTRICAL GENERATION}

\begin{tabular}{|c|c|c|c|c|c|c|}
\hline $\begin{array}{l}\text { YEAR LIO } \\
1975 \\
1980 \\
1985 \\
1990 \\
2000 \\
2010 \\
2020\end{array}$ & $\begin{array}{l}8 \text { GAS } \\
2.43 \\
2.30 \\
2.20 \\
2.10 \\
1.80 \\
1.70 \\
1.60 \\
1.50 \\
1.50\end{array}$ & 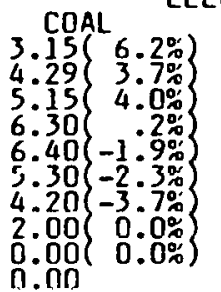 & 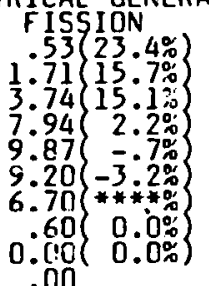 & $\left.\begin{array}{l}1.04 \\
1.10 \\
1.38 \\
1.80 \\
2.52 \\
3.00 \\
3.20 \\
3.20 \\
3.20\end{array}\right\}$ & $\begin{array}{l}5.3 \\
3.4 \\
1.7 \\
0.0 \\
0.0\end{array}$ & $\begin{array}{c}\text { CTR } \\
0.001 \\
.01 \\
32\end{array}$ \\
\hline
\end{tabular}

COAL TO SYNFUELS TOTAL ENERGY CARRIERS (DIRECT USE) ELECT

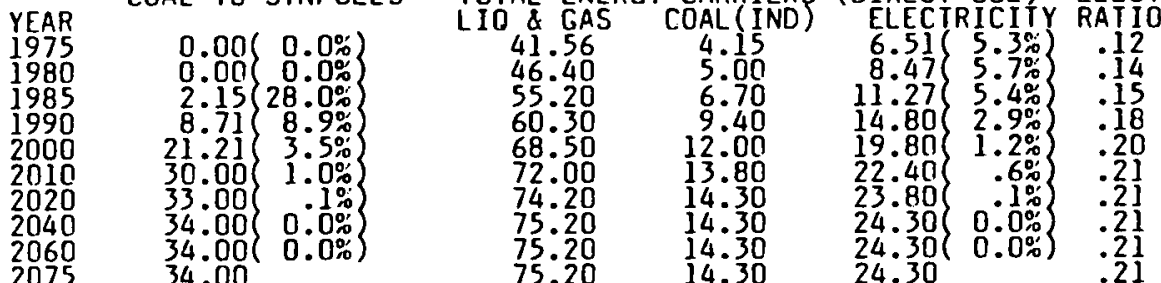

FINAL CONSUMPTION END USE

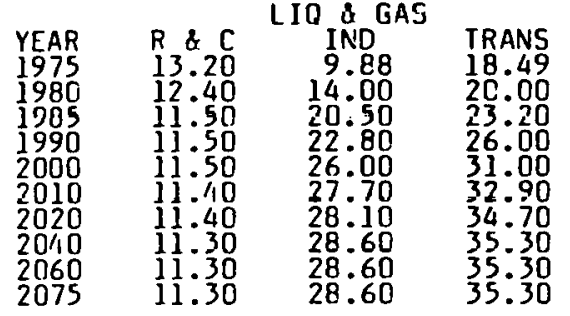

\begin{tabular}{ccr}
\multicolumn{3}{c}{ CLCCTRICITY } \\
$R_{2} \& C^{2}$ & IND & TRANS \\
3.78 & 2.71 & .02 \\
4.60 & 3.80 & .07 \\
5.70 & 5.40 & .17 \\
7.00 & 7.40 & .40 \\
8.80 & 10.00 & 1.00 \\
9.90 & 11.30 & 1.20 \\
10.30 & 12.10 & 1.40 \\
10.40 & 12.30 & 1.60 \\
10.40 & 12.30 & 1.60 \\
10.40 & 12.30 & 1.60
\end{tabular}

TOTALS

\begin{tabular}{|c|c|c|c|c|c|}
\hline $\begin{array}{l}\text { YFAR } \\
1975 \\
1980 \\
1985 \\
1990 \\
2000 \\
2010 \\
2020 \\
2040 \\
2060 \\
2075\end{array}$ & $\begin{array}{l}R \quad r . \\
16.98 \\
17.00 \\
17.20 \\
18.50 \\
20.30 \\
21.30 \\
21.70 \\
21.70 \\
21.70 \\
21.70\end{array}$ & $\begin{array}{c}1 \times n \\
16.73 \\
22.80 \\
32.80 \\
39.60 \\
48.00 \\
52.80 \\
54.50 \\
55.20 \\
55.20 \\
55.20\end{array}$ & $\begin{array}{l}\text { TRANS } \\
18.51 \\
20.17 \\
23.37 \\
26.40 \\
32.00 \\
34.10 \\
36.10 \\
36.90 \\
36.90 \\
36.90\end{array}$ & $\begin{array}{r}\text { TחI IISF } \\
52.22 \\
59.97 \\
73.37 \\
84.50 \\
100.30 \\
108.20 \\
112.30 \\
113.80 \\
113.80 \\
113.80\end{array}$ & $\left.\begin{array}{r}\text { TOI RF } R \\
70.94 \\
85.72 \\
105.83 \\
129.81 \\
155.29 \\
171.44 \\
179.09 \\
182.79 \\
182.69 \\
182.69\end{array}\right\}$ \\
\hline
\end{tabular}

\footnotetext{
CUMA. RESOURCE USE
$1975-2024$
$1995-2044$
$1975-2075$

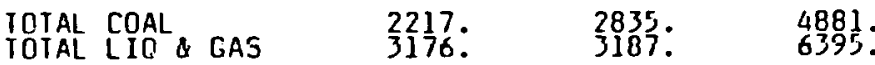

Figure D-8. Energy activity levels national annual totals (E15 Btu).
} 
TOIAL ANNUAL SYSTEM COSI (E9 DOLLARS)

\begin{tabular}{|c|c|c|c|}
\hline $\begin{array}{l}\text { YEAR } \\
1975 \\
1980 \\
1985 \\
1990 \\
2000 \\
2010 \\
2020 \\
2040 \\
2060 \\
2075\end{array}$ & SET2 ${ }^{\operatorname{cosi} A S S U !}$ & $\begin{array}{l}\text { MPIIONS SEIS } \\
\text { ET3 SET4 } \\
\\
148.1 \\
191.5 \\
254.3 \\
334.8 \\
464.6 \\
563.3 \\
619.2 \\
659.2 \\
712.0 \\
764.1\end{array}$ & $\begin{array}{l}\text { SETS } \\
148.1 \\
191.5 \\
254.1 \\
334.2 \\
461.9 \\
555.4 \\
608.7 \\
659.2 \\
712.0 \\
764.1\end{array}$ \\
\hline $\begin{array}{c}T C \underbrace{0 \% 5}_{0 \%} \\
5 \% \\
100 \\
15 \% \\
15 \%\end{array}$ & DISCOUNTED PRESENT VALUE OF & $\begin{array}{r}\text { CUM. SYSTEM COST } \\
56658.8 \\
7346.5 \\
2862.9 \\
1692.2\end{array}$ & $\begin{array}{r}56351.3 \\
7303.2 \\
2854.1 \\
1689.7\end{array}$ \\
\hline 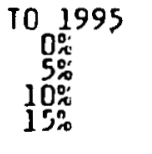 & & $\begin{array}{r}51509.8 \\
11286.0 \\
5497.9 \\
3642.4\end{array}$ & $\begin{array}{r}51208.0 \\
11178.5 \\
5448.5 \\
3614.9\end{array}$ \\
\hline $\begin{array}{c}10 \underset{0 \%}{2010} \\
0 \% \\
10 \% \\
15 \% \\
10 \%\end{array}$ & & $\begin{array}{r}44235.5 \\
12700.1 \\
6682.0 \\
4581.5\end{array}$ & $\begin{array}{r}43996.8 \\
12560.4 \\
6588.6 \\
4512.7\end{array}$ \\
\hline $\begin{array}{c}T 0 \underset{0 \%}{2020} \\
0 \% \\
10 \% \\
15 \%\end{array}$ & & $\begin{array}{r}38323.3 \\
12909.5 \\
7045.1 \\
4881.6\end{array}$ & $\begin{array}{r}38179.0 \\
12805.0 \\
6964.4 \\
4816.1\end{array}$ \\
\hline
\end{tabular}

HEALTH \& ENVIRON - EMISSIONS \& EFFECTS

\begin{tabular}{|c|c|c|c|c|c|c|}
\hline $\begin{array}{l}\text { YEAR } \\
1975 \\
1980 \\
1985 \\
1990 \\
2000 \\
2010 \\
2020 \\
2040 \\
2060 \\
2075\end{array}$ & $\begin{array}{l}\text { POP EXP } \\
\text { E3 } \\
\text { MAN REM } \\
14.31 \\
46.44 \\
102.33 \\
217.62 \\
288.63 \\
383.40 \\
450.90 \\
529.20 \\
583.20 \\
583.20\end{array}$ & $\begin{array}{r}\text { KR-B5 } \\
\text { E6 } \\
\text { CURIES } \\
13.04 \\
42.07 \\
92.00 \\
195.32 \\
242.80 \\
226.32 \\
164.82 \\
14.76 \\
0.00 \\
.00\end{array}$ & $\begin{array}{r}\text { TRIT } \\
\text { ES } \\
\text { CURIES } \\
4.66 \\
15.06 \\
32.99 \\
70.07 \\
64.19 \\
89.11 \\
75.26 \\
36.25 \\
35.21 \\
35.21\end{array}$ & $\begin{array}{c}\text { RAD WASTE } \\
\text { E3 } \\
\text { CUFY } \\
2.92 \\
9.41 \\
20.57 \\
43.67 \\
54.29 \\
50.60 \\
36.85 \\
3.30 \\
0.00 \\
.00\end{array}$ & $\begin{array}{r}\text { SPENI } \\
\text { BLANKET } \\
\text { E3 CU F } \\
0.00 \\
.55 \\
2.75 \\
6.60 \\
45.10 \\
275.00 \\
550.00 \\
1045.00 \\
1188.00 \\
1188.00\end{array}$ & $\begin{array}{l}0.00 \\
0.00 \\
0.00 \\
0.00 \\
0.00 \\
0.00 \\
0.00 \\
0.00 \\
0.00 \\
0.00\end{array}$ \\
\hline $\begin{array}{l}\text { YEAR } \\
1975 \\
1980 \\
1985 \\
1990 \\
2000 \\
2010 \\
2020 \\
2040 \\
2060\end{array}$ & $\begin{array}{c}\text { E9 } 20 \\
5.67 \\
6.53 \\
7.71 \\
8.80 \\
9.68 \\
9.74 \\
9.55 \\
8.81 \\
8.10 \\
8.10\end{array}$ & $\begin{array}{c}\text { E6 TONS } \\
8.32 \\
9.10 \\
10.62 \\
11.99 \\
14.23 \\
15.04 \\
15.72 \\
15.80 \\
15.65 \\
15.65\end{array}$ & $\begin{array}{c}\text { NOX } \\
\text { E6 TONS } \\
18.08 \\
21.10 \\
25.35 \\
28.80 \\
31.54 \\
31.78 \\
30.95 \\
28.44 \\
26.07 \\
26.1 .7\end{array}$ & $\begin{array}{c}\text { SO2 } \\
\text { E6 TONS } \\
14.12 \\
16.31 \\
21.112 \\
24.56 \\
27.61 \\
28.80 \\
28.56 \\
27.24 \\
25.93 \\
25.93\end{array}$ & $\begin{array}{c}\text { PART } \\
\text { E6 T.NS } \\
8.36 \\
9.96 \\
12.89 \\
16.77 \\
20.76 \\
23.20 \\
23.86 \\
23.68 \\
23.44 \\
23.44 .\end{array}$ & $\begin{array}{c}\text { HC } \\
\text { E6 TONS } \\
2.73 \\
3.01 \\
3.46 \\
3.71 \\
4.03 \\
4.09 \\
4.16 \\
4.13 \\
4.07 \\
4.07\end{array}$ \\
\hline $\begin{array}{l}\text { YEAR } \\
1975 \\
1980 \\
1985 \\
1990 \\
2000 \\
2010 \\
2020 \\
2040 \\
2060\end{array}$ & $\begin{array}{l}\text { LAND USE } \\
\text { E6 ACRES } \\
14.17 \\
18.01 \\
22.85 \\
30.36 \\
37.63 \\
41.65 \\
42.99 \\
42.09 \\
40.58 \\
40.58\end{array}$ & $\begin{array}{c}\text { DEATHS } \\
\text { F.3 } \\
1.14 \\
1.58 \\
1.93 \\
2.36 \\
3.13 \\
3.131 \\
3.03 \\
2.48 \\
1.99 \\
1.99\end{array}$ & $\begin{array}{l}\text { INJURIES } \\
\text { E3 } \\
26.12 \\
35.45 \\
44.47 \\
57.34 \\
80.26 \\
86.37 \\
84.09 \\
72.70 \\
62.30 \\
62.30\end{array}$ & $\begin{array}{c}\text { MAN DAYS } \\
\text { LOST E6 } \\
1.71 \\
2.33 \\
2.90 \\
3.67 \\
5.05 \\
5.34 \\
5.15 \\
4.37 \\
3.67 \\
3.67\end{array}$ & $\begin{array}{c}\text { SOL ID WASTE } \\
\text { E9 TONS } \\
.20 \\
.28 \\
.35 \\
.48 \\
.58 \\
.57 \\
.52 \\
.37 \\
.24 \\
.24\end{array}$ & \\
\hline
\end{tabular}

Figure D-8. Continued. 
ACCEL.FUSION NO IMPORTS, NO FBR (BASED ON HZOS) . FOSSIL RESOURCES TOTAL USE.

ELECIRIC GENERATION

\& GAS COAL

$\begin{array}{lc}\text { YEAR } & \text { LIO } \& \text { GAS } \\ 1975 & 52.80 \\ 1980 & 49.98 \\ 1985 & 49.45 \\ 1990 & 47.79 \\ 2000 & 39.79 \\ 2010 & 37.58 \\ 2020 & 26.11 \\ 2040 & 23.36 \\ 2060 & 20.29 \\ 2075 & 20.29\end{array}$

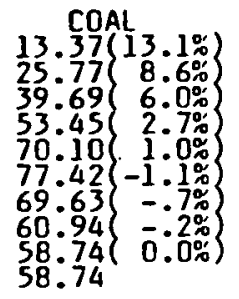

LIO \& GAS

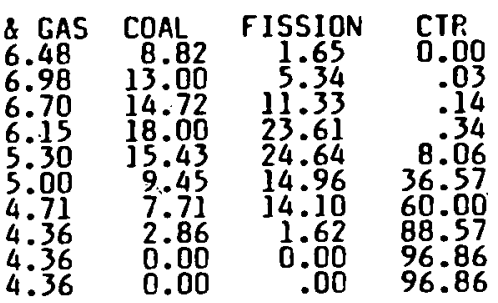

$\begin{array}{lr}\text { YEAR LIC } & \& \text { GAS } \\ 1975 & 2.43 \\ 1980 & 2.30 \\ 1985 & 2.20 \\ 1990 & 2.10 \\ 2000 & 1.80 \\ 2010 & 1.70 \\ 2020 & 1.60 \\ 2040 & 1.50 \\ 2060 & 1.50 \\ 2075 & 1.50\end{array}$

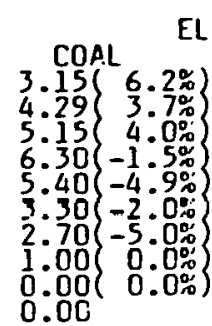

ELECTRICAL GENEF

$4.36 \quad 0.00$

$.00 \quad 96.86$

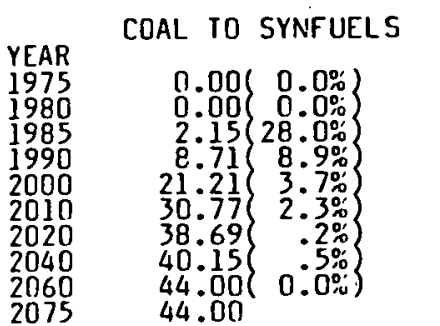
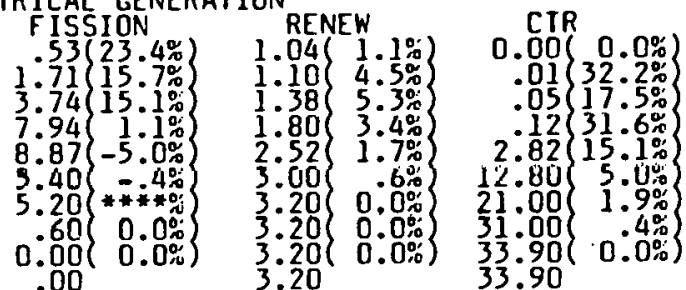

TOTAL ENERGY CARRIERS (DI
LIQ \& GAS COAL (IND)

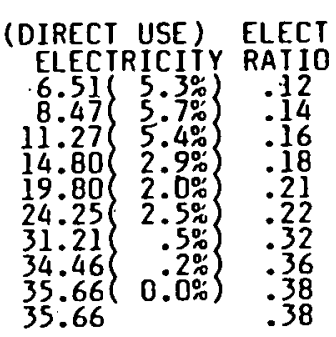

FINAL CONSUMPTION END USE

$\begin{array}{lccc} & & \text { III I RAS } \\ \text { YEAR } & \text { R \& } & \text { IND } & \text { IRANS } \\ 1975 & 13.20 & 9.88 & 18.49 \\ 1980 & 10.29 & 11.62 & 16.59 \\ 1985 & 8.27 & 14.74 & 16.69 \\ 1990 & 8.20 & 16.26 & 18.5 \\ 2000 & 7.50 & 16.97 & 20.2 \\ 2010 & 7.79 & 18.92 & 22.49 \\ 2020 & 6.19 & 16.14 & 20.6 \\ 2040 & 6.46 & 16.35 & 20.18 \\ 2060 & 6.42 & 16.24 & 20.04 \\ 2075 & 6.42 & 16.24 & 20.04\end{array}$

\begin{tabular}{rrr}
\multicolumn{3}{c}{ FI.ECTRICITY } \\
R \& $C^{2}$ & IND & TRANS \\
3.78 & 2.71 & .02 \\
4.60 & 3.80 & .07 \\
5.77 & 5.40 & .17 \\
7.00 & 7.40 & .40 \\
0.00 & 10.00 & 1.00 \\
10.72 & 12.23 & 1.30 \\
13.31 & 13.81 & 1.84 \\
14.75 & 17.44 & 2.27 \\
15.26 & 18.05 & 2.35 \\
15.26 & 18.05 & 2.35
\end{tabular}

TOTALS

\begin{tabular}{|c|c|c|c|c|c|}
\hline $\begin{array}{l}\text { YEAK } \\
1975 \\
1980 \\
1985 \\
1990 \\
2000 \\
2010 \\
2020 \\
2040 \\
2060 \\
2075\end{array}$ & $\begin{array}{l}R \& \text { \& } \\
16.98 \\
14.89 \\
13.97 \\
15.20 \\
16.30 \\
18.51 \\
20.30 \\
21.21 \\
21.68 \\
21.68\end{array}$ & $\begin{array}{c}\text { IND } \\
16.73 \\
27.42 \\
41.84 \\
49.06 \\
58.97 \\
66.95 \\
54.91 \\
51.10 \\
48.59 \\
48.59\end{array}$ & $\begin{array}{l}\text { IRANS } \\
18.51 \\
16.66 \\
16.86 \\
18.94 \\
21.23 \\
23.79 \\
22.51 \\
22.45 \\
22.39 \\
22.39\end{array}$ & $\begin{array}{r}\text { TOT USE } \\
52.22 \\
58.97 \\
72.67 \\
83.20 \\
96.50 \\
109.25 \\
97.72 \\
94.76 \\
92.66 \\
92.66\end{array}$ & $\left.\begin{array}{r}\text { TOT RES } \\
70.94 \\
84.26 \\
104.25 \\
130.34 \\
149.79 \\
175.13 \\
178.98 \\
183.63 \\
185.03 \\
185.03\end{array}\right\}$ \\
\hline
\end{tabular}

$$
\begin{aligned}
& \underset{1975-2024}{\text { CUM. RESOURCE USE }} 1995-2044 \quad 1975-2075
\end{aligned}
$$

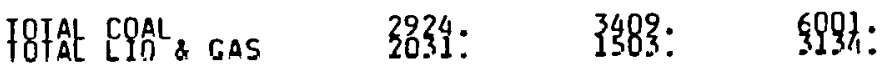

Figure D-9. Energy activity levels national annual totals (E15 Btu). 
IOTAL ANHUAL SYSIEM COST (E9 DOLLARS)

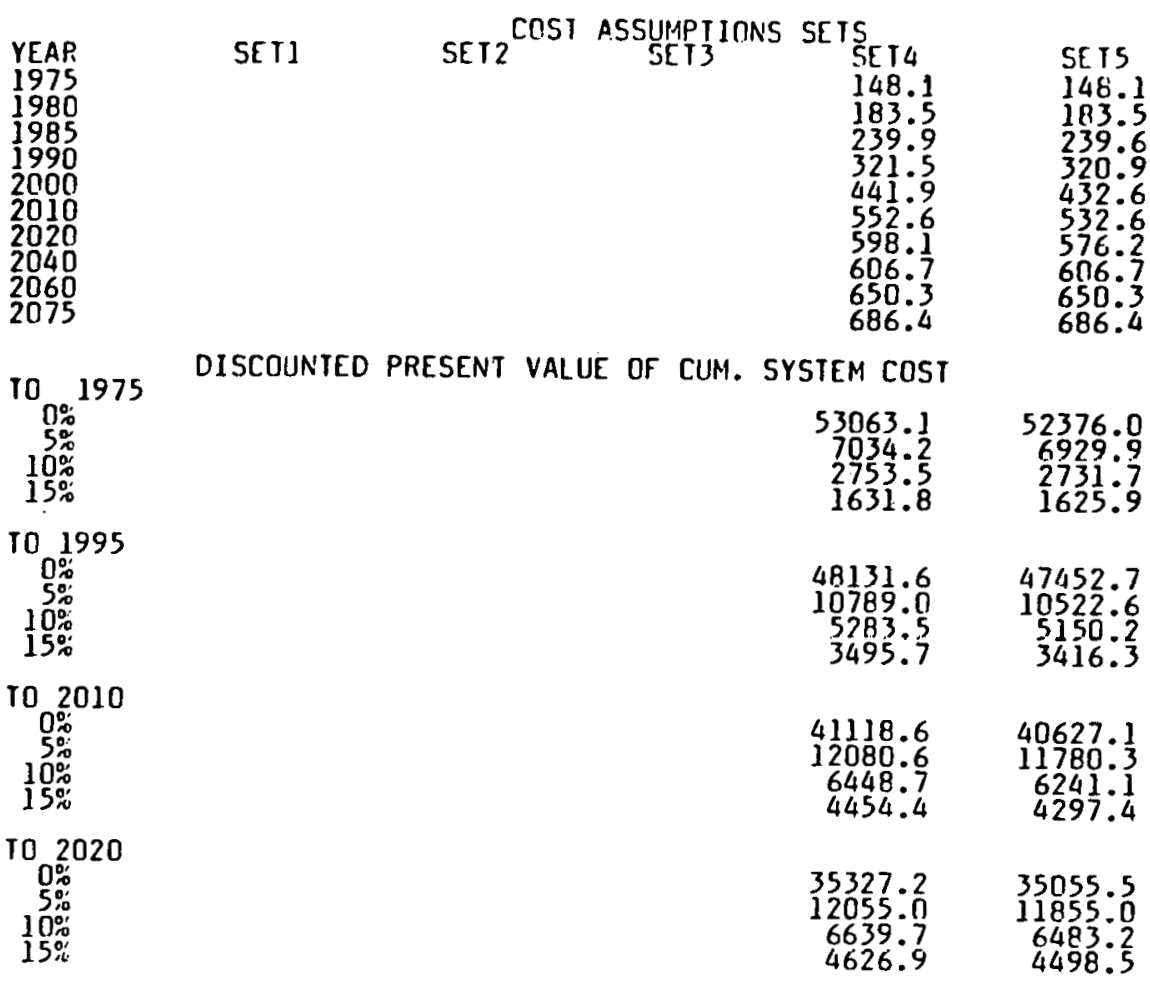

HEALIH \& ENVIRON - EMISSIONS \& EFFECTS

\begin{tabular}{|c|c|c|c|c|c|c|}
\hline $\begin{array}{l}\text { YEAR } \\
1975 \\
1980 \\
1985 \\
1990 \\
2000 \\
2010 \\
2020 \\
2040 \\
2060 \\
2075\end{array}$ & $\begin{array}{l}\text { POP EXP } \\
\text { E3 } \\
\text { MAN REM } \\
14.31 \\
46.44 \\
102.33 \\
217.62 \\
315.63 \\
491.40 \\
707.40 \\
853.20 \\
915.30 \\
915.30\end{array}$ & $\begin{array}{r}\text { KR-BS } \\
\text { E6 } \\
\text { CURIES } \\
13.04 \\
42.07 \\
92.00 \\
195.32 \\
218.20 \\
132.84 \\
127.92 \\
14.76 \\
0.00 \\
.00\end{array}$ & $\begin{array}{r}\text { TRIT } \\
\text { ES } \\
\text { CURIES } \\
4.66 \\
15.06 \\
32.99 \\
70.07 \\
82.65 \\
68.38 \\
79.99 \\
55.81 \\
55.26 \\
55.26\end{array}$ & $\begin{array}{c}\text { RAD WASIE } \\
\text { E3 } \\
\text { CU FT } \\
2.92 \\
9.41 \\
20.57 \\
43.67 \\
48.79 \\
29.70 \\
28.60 \\
3.30 \\
0.00 \\
.00\end{array}$ & $\begin{array}{r}\text { SPENT } \\
\text { ELANKET } \\
\text { E3 CU FT } \\
0.00 \\
.55 \\
2.75 \\
6.60 \\
155.10 \\
704.00 \\
1155.00 \\
1705.00 \\
1864.50 \\
1864.50\end{array}$ & (SPARE \\
\hline
\end{tabular}

\begin{tabular}{|c|c|c|c|c|c|c|}
\hline $\begin{array}{l}\text { YEAR } \\
1975 \\
1980 \\
1985 \\
1990 \\
2000 \\
2010 \\
2020 \\
2040 \\
2060 \\
2075\end{array}$ & $\begin{array}{c}\text { CO2 } \\
\text { E9 TONS } \\
5.67 \\
6.68 \\
8.14 \\
9.20 \\
9.65 \\
9.66 \\
7.50 \\
6.21 \\
5.49 \\
5.49\end{array}$ & $\begin{array}{c}\text { CO } \\
\text { E6 IONS } \\
8.32 \\
7.94 \\
8.47 \\
9.50 \\
10.43 \\
11.41 \\
10.03 \\
9.49 \\
9.24 \\
9.24\end{array}$ & $\begin{array}{c}\text { NOX } \\
\text { E6 TONS } \\
18.08 \\
21.38 \\
25.93 \\
29.24 \\
30.39 \\
30.29 \\
24.37 \\
20.46 \\
18.44 \\
18.44\end{array}$ & $\begin{array}{c}502 \\
\text { E6 TONS } \\
14.12 \\
19.74 \\
27.13 \\
30.82 \\
34.37 \\
36.30 \\
26.64 \\
22.18 \\
19.72 \\
19.72\end{array}$ & $\begin{array}{c}\text { PART } \\
\text { E6 TONS } \\
8.36 \\
18.27 \\
30.74 \\
35.81 \\
44.21 \\
49.12 \\
31.79 \\
25.22 \\
21.34 \\
21.34\end{array}$ & $\begin{array}{c}\text { HC } \\
\text { E6 } 70 \mathrm{NS} \\
2.73 \\
2.74 \\
2.96 \\
3.14 \\
3.15 \\
3.26 \\
2.56 \\
2.30 \\
2.13 \\
2.13\end{array}$ \\
\hline $\begin{array}{l}\text { YEAR } \\
1975 \\
1980 \\
1985 \\
1990 \\
2000 \\
2010 \\
2020 \\
2040 \\
2060 \\
2075\end{array}$ & $\begin{array}{l}\text { LAND UISE } \\
\text { E6 ACRES } \\
14.17 \\
19.19 \\
25.52 \\
33.93 \\
40.16 \\
45.95 \\
49.46 \\
50.15 \\
50.38 \\
50.38\end{array}$ & $\begin{array}{c}\text { DEA THS } \\
\text { E3 } \\
1.14 \\
2.16 \\
3.18 \\
3.94 \\
4.55 \\
4.54 \\
3.43 \\
2.60 \\
2.18 \\
2.18\end{array}$ & $\begin{array}{c}\text { INJURIES } \\
\text { E3 } \\
26.12 \\
46.75 \\
68.76 \\
88.28 \\
107.17 \\
111.80 \\
93.59 \\
77.03 \\
70.52 \\
70.52\end{array}$ & $\begin{array}{c}\text { MAN DAYS } \\
\text { LOSTEE } \\
1.71 \\
3.13 \\
4.61 \\
5.84 \\
6.96 \\
7.15 \\
5.77 \\
4.62 \\
4.12 \\
4.12\end{array}$ & $\begin{array}{c}\text { SOLID WASIE } \\
\text { E9 TONS } \\
.20 \\
.29 \\
.37 \\
.50 \\
.54 \\
.46 \\
.46 \\
.35 \\
.31\end{array}$ & \\
\hline
\end{tabular}

Figure D-9. Continued. 


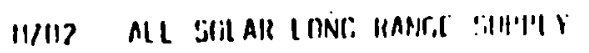

$$
\text { FIISSIL JiE grinilecs }
$$

\begin{tabular}{|c|c|}
\hline 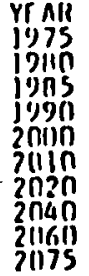 & $\begin{array}{r}\text { II } 8 \text { r.AS } \\
52 . P 11 \\
49.98 \\
49.45 \\
45.95 \\
39.79 \\
27.19 \\
26.11 \\
23.36 \\
20.29 \\
20.29\end{array}$ \\
\hline
\end{tabular}
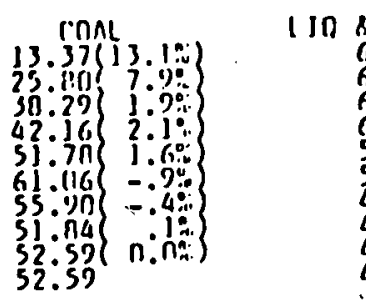

(I'n?.(1: In! H.111)

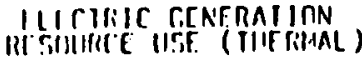

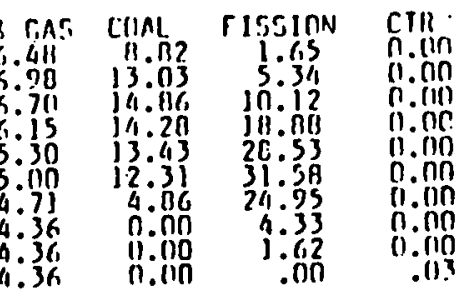

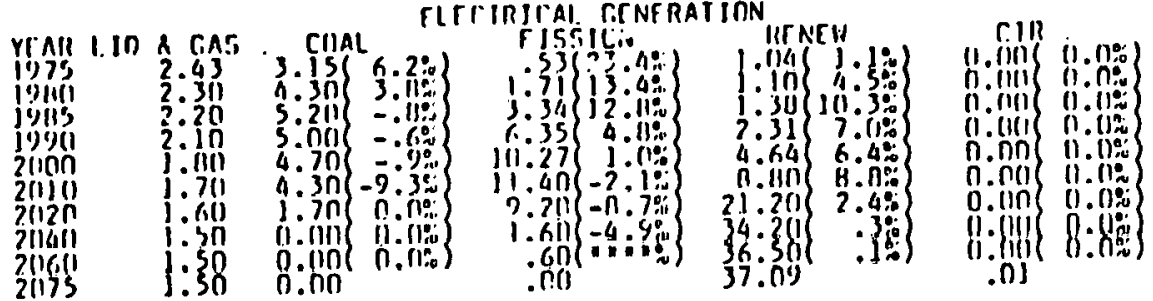

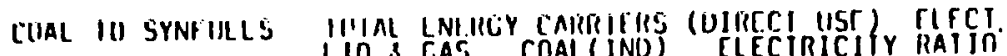

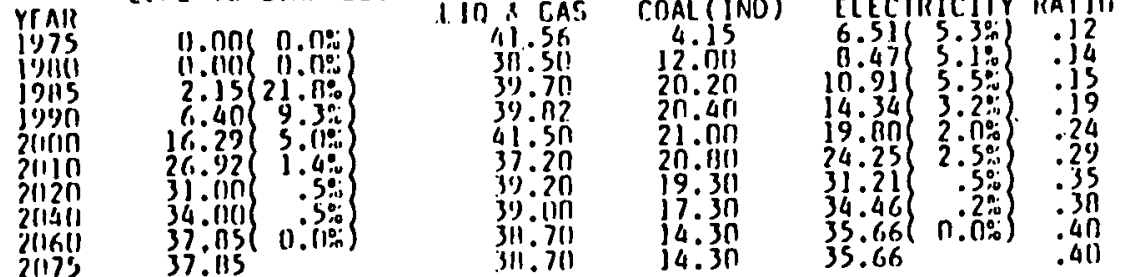

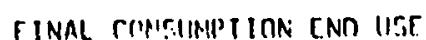

\begin{tabular}{|c|c|c|}
\hline 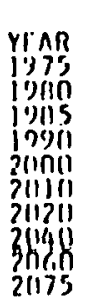 & $\begin{array}{l}R A R \\
13.211 \\
102.29 \\
0.27 \\
7.59 \\
6.96 \\
5.119 \\
6.02 \\
5.116 \\
5.112 \\
5.02\end{array}$ & 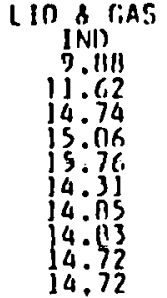 \\
\hline
\end{tabular}

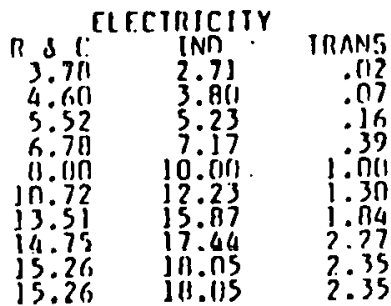

IPTALS

\begin{tabular}{|c|c|c|c|c|c|}
\hline 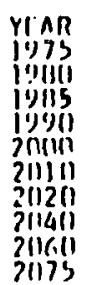 & 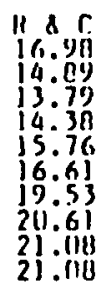 & $\begin{array}{l}1 N 1) \\
16.73 \\
27.47 \\
4(1.17 \\
42.63 \\
46.76 \\
47.34 \\
50.117 \\
49.57 \\
47.07\end{array}$ & 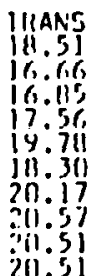 & 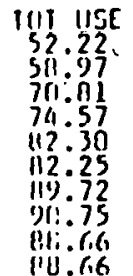 & 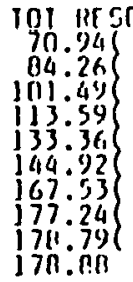 \\
\hline
\end{tabular}

\begin{tabular}{|c|c|}
\hline & 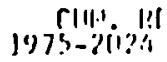 \\
\hline $\begin{array}{l}\text { WIAL CYIAL } \\
\text { nIAL TIII \& TAS }\end{array}$ & $\begin{array}{l}2394 . \\
1911: 0\end{array}$ \\
\hline
\end{tabular}

Figure D-10. Energy activity leyels nationa1 annual totals (E15 Btu). 


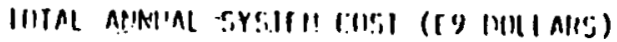

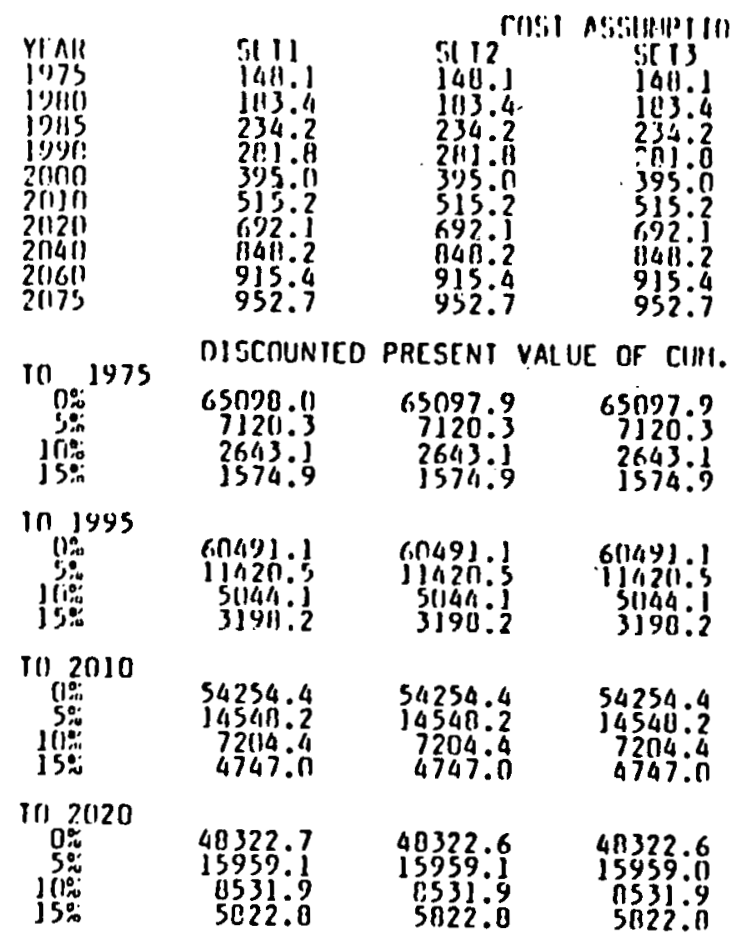

IICALIII A ENVIRON - EMISSIONS \& EFFECIS

\begin{tabular}{|c|c|c|c|c|c|c|}
\hline $\begin{array}{l}\text { YFAll } \\
1975 \\
1900 \\
19115 \\
1990 \\
20100 \\
2010 \\
2020 \\
2040 \\
2060\end{array}$ & $\begin{array}{r}\text { PIP EXV } \\
\text { C3 } \\
\text { MAN REI } \\
34.31 \\
46.17 \\
90.10 \\
171.45 \\
277.29 \\
307.00 \\
246.40 \\
43.20 \\
16.20 \\
.27\end{array}$ & $\begin{array}{r}\text { KR-BS } \\
\text { E6 } \\
\text { CURIES } \\
13 . \pi 4 \\
42.07 \\
82.16 \\
156.21 \\
252.66 \\
260.44 \\
226.32 \\
39.36 \\
14.76 \\
.00\end{array}$ & $\begin{array}{r}\text { IRII } \\
\text { E5 } \\
\text { CUIIES } \\
4.66 \\
15.015 \\
29.39 \\
55.80 \\
90.38 \\
100.32 \\
00.96 \\
14.08 \\
5.28 \\
.02\end{array}$ & $\begin{array}{c}\text { WPD WASIE } \\
\text { C3 } \\
\text { CU FT } \\
2.92 \\
9.41 \\
10.37 \\
34.93 \\
56.49 \\
62.70 \\
50.60 \\
6.00 \\
3.30\end{array}$ & 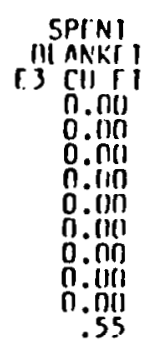 & 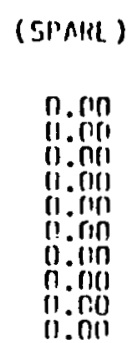 \\
\hline
\end{tabular}

\begin{tabular}{|c|c|c|c|c|c|c|}
\hline $\begin{array}{l}\text { YeAn } \\
\text { j975 } \\
19801 \\
1905 \\
\text { j990 } \\
2000 \\
2010 \\
2020 \\
2040 \\
2060 \\
2075\end{array}$ & $\begin{array}{c}\text { Co? } \\
\text { 1.9 Tins } \\
5.67 \\
6.68 \\
7.99 \\
7.94 \\
7.91 \\
7.37 \\
6.40 \\
5.53 \\
5.17 \\
5.17\end{array}$ & $\begin{array}{c}\text { Co } \\
\text { Er. InNS } \\
8.32 \\
7.94 \\
8.41 \\
11.611 \\
9.28 \\
8.52 \\
8.01 \\
8.59 \\
0.42 \\
0.42\end{array}$ & $\begin{array}{l}\text { NOX } \\
\text { E6 IONS } \\
10.08 \\
21.39 \\
25: 55 \\
25: 36 \\
25: 37 \\
23.98 \\
20.83 \\
18.30 \\
17.27 \\
17.27\end{array}$ & 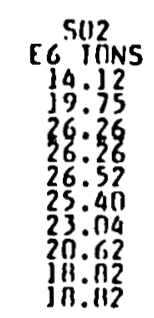 & $\begin{array}{c}\text { PA1+T } \\
\text { T6 INNS } \\
11.36 \\
11.27 \\
211.116 \\
29.14 \\
311.54 \\
29.54 \\
27.51 \\
24.79 \\
21.113 \\
21.113\end{array}$ & 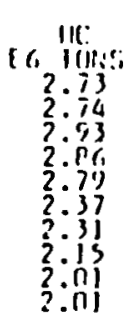 \\
\hline 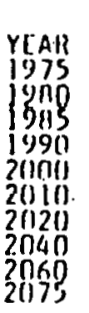 & $\begin{array}{l}\text { LAND UST } \\
\text { [G ACNIS } \\
14.17 \\
19.20 \\
21.80 \\
213.00 \\
35.94 \\
42.01 \\
49.39 \\
53.50 \\
34.97 \\
55.08\end{array}$ & $\begin{array}{l}\text { DEAIHS } \\
53 \\
1.34 \\
2.16 \\
3.06 \\
3.34 \\
3.36 \\
3.401 \\
2.79 \\
2.22 \\
2.055 \\
2.04\end{array}$ & $\begin{array}{c}\text { INJURIES } \\
\text { [3 } \\
26.12 \\
46.401 \\
66.42 \\
70.45 \\
80.36 \\
88.30 \\
76.04 \\
65.31 \\
63.83 \\
6.30\end{array}$ & $\begin{array}{c}\text { MAN DAYS } \\
\text { LUSi E6 } \\
1.71 \\
3: 13 \\
4.45 \\
4.66 \\
5.10 \\
5: 54 ! \\
4.19 \\
3: 94 \\
3: 30\end{array}$ & 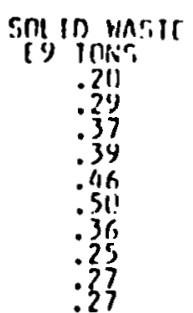 & \\
\hline
\end{tabular}

Figure D-10. Continued. 
FOSSIL RESQURCES
TOTAL USE

$\begin{array}{cc}\text { YEAR } & \text { LIQ } 2 \text { GAS } \\ 1975 & 52.80 \\ 1980 & 49.98 \\ 1985 & 49.45 \\ 1990 & 45.95 \\ 2000 & 39.79 \\ 2010 & 27.14 \\ 2020 & 26.11 \\ 2040 & 23.36 \\ 2060 & 20.29 \\ 2075 & 20.29\end{array}$

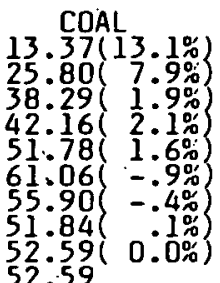

ELECTRIC GENERATION

RESOURCE USE (THERMAL)

\begin{tabular}{cccc} 
LIO \& GAS & COAL & FISSION & \multicolumn{1}{c}{ CIR } \\
6.48 & 8.82 & 1.65 & 0.00 \\
6.98 & 13.03 & 5.34 & 0.00 \\
6.70 & 14.86 & 10.12 & 0.00 \\
6.15 & 14.28 & 18.88 & .03 \\
5.30 & 13.43 & 28.53 & .34 \\
5.00 & 12.31 & 31.58 & 8.00 \\
4.71 & 4.86 & 24.55 & 37.14 \\
4.36 & 0.00 & 4.33 & 74.29 \\
4.36 & 0.00 & 1.62 & 95.14 \\
4.36 & 0.00 & .00 & 96.86
\end{tabular}

\section{ELEC TR ICAL GENERATION}

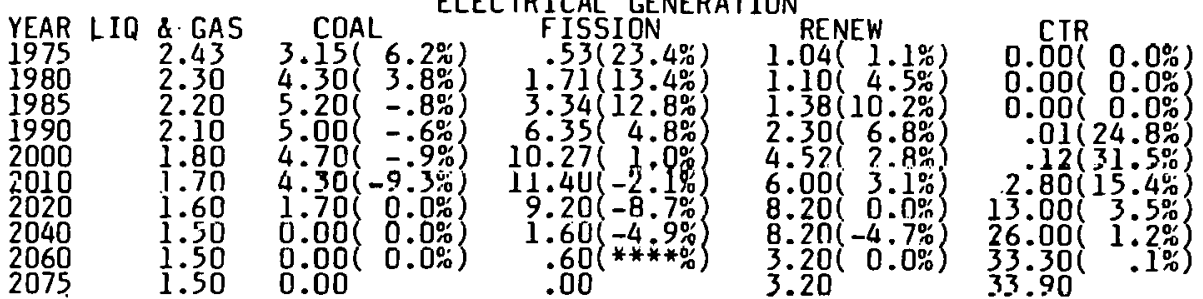

COAL TO SYNFUELS TOTAL ENERGY CARRIERS (DIRECT USE) ELECT

$\begin{array}{ll}\text { YEAR } & \\ 1975 & 0.00(0.0 \%) \\ 1980 & 0.00(0.0 \%) \\ 1985 & 2.15(21.8 \%) \\ 1990 & 6.40(9.3 \%) \\ 2000 & 16.29(5.0 \% \\ 2010 & 26.92(1.4 \%) \\ 2020 & 31.00(\% \% \\ 2040 & 34.00(\%) \\ 2060 & 37.85(0.0 \%) \\ 2075 & 37.85\end{array}$

\begin{tabular}{|c|c|c|c|}
\hline $\begin{array}{l}\text { UTAL ENERGY } \\
\text { I0 \& GAS } \\
41.56 \\
38.50 \\
39.70 \\
39.82 \\
41.50 \\
37.20 \\
39.20 \\
39.00 \\
38.70 \\
38.70\end{array}$ & $\begin{array}{l}\text { CARRIERS } \\
\text { COAI. (IND) } \\
4.15 \\
12.00 \\
20.20 \\
20.40 \\
21.00 \\
20.80 \\
19.30 \\
17.30 \\
14.30 \\
14.30\end{array}$ & $\begin{array}{r}\text { CDIRECT } \\
\text { FI.ECT } \\
6.511 \\
8.47 \\
10.91 \\
14.34 \\
19.80 \\
24.251 \\
31.21 \\
34.460 \\
35.660 \\
35.66\end{array}$ & 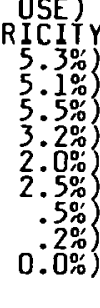 \\
\hline
\end{tabular}

FINAL CONSUMPTION END USE

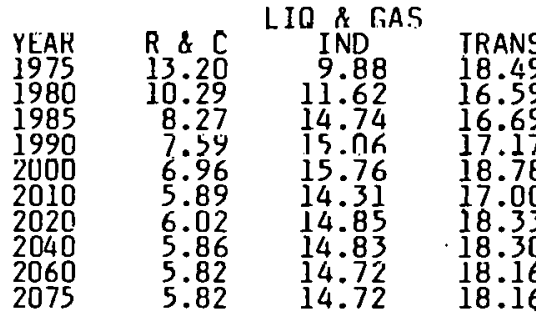

\begin{tabular}{rrr}
\multicolumn{3}{c}{ ELECTRICITY } \\
$R_{\text {\& C C IND }}$ & TRANS \\
3.78 & 2.71 & .02 \\
4.60 & 3.80 & .07 \\
5.52 & 5.23 & .16 \\
6.78 & 7.17 & .39 \\
8.80 & 10.00 & 1.00 \\
10.72 & 12.23 & 1.30 \\
13.51 & 15.87 & 1.84 \\
14.75 & 17.44 & 2.27 \\
15.26 & 18.05 & 2.35 \\
15.26 & 18.05 & 2.35
\end{tabular}

TOTALS

\begin{tabular}{|c|c|c|c|c|c|}
\hline $\begin{array}{l}\text { YEAR } \\
1975 \\
1980 \\
1985 \\
1990 \\
2000 \\
2010 \\
2020 \\
2040 \\
2060 \\
2075\end{array}$ & $\begin{array}{l}R \& C \\
16.98 \\
14.89 \\
13.79 \\
14.38 \\
15.76 \\
16.61 \\
19.53 \\
20.61 \\
21.08 \\
21.08\end{array}$ & $\begin{array}{l}\text { IND } \\
16.73 \\
27.42 \\
40.17 \\
42.63 \\
46.76 \\
47.34 \\
50.02 \\
49.57 \\
47.07 \\
47.07\end{array}$ & $\begin{array}{l}\text { TRANS } \\
18.31 \\
16.66 \\
16.85 \\
17.56 \\
19.78 \\
18.30 \\
20.17 \\
20.57 \\
20.51 \\
20.51\end{array}$ & $\begin{array}{l}\text { IQI USSF. } \\
52.22 \\
58.97 \\
70.81 \\
74.57 \\
82.30 \\
82.25 \\
89.72 \\
90.75 \\
88.66 \\
88.66\end{array}$ & $\begin{array}{r}\text { TnT RES } \\
70.94 \\
84.26 \\
101.49 \\
113.59 \\
133.35 \\
144.92 \\
167.53 \\
177.25 \\
178.78 \\
178.88\end{array}$ \\
\hline
\end{tabular}

\begin{tabular}{|c|c|}
\hline & $\begin{array}{l}\text { CUM RESOURCE USE } \\
1975-2024 \\
1995-2044\end{array}$ \\
\hline
\end{tabular}

Figure D-11. Energy activity levels national annual totals (E15 Btu). 
TOIAL ANNUAL SYSIEN COST (E9 DOLLARS)

\begin{tabular}{|c|c|c|c|c|}
\hline $\begin{array}{l}\text { YEAR } \\
1975 \\
1980 \\
1985 \\
1990 \\
2000 \\
2010 \\
2020 \\
2040 \\
2060 \\
2075\end{array}$ & $\begin{array}{l}\text { SETJ } \\
148.1 \\
183.4 \\
234.2 \\
281.9 \\
395.8 \\
512.6 \\
641.2 \\
706.2 \\
681.8 \\
675.6\end{array}$ & $\begin{array}{l}\text { SEI2 COST } \\
148.1 \\
183.4 \\
234.2 \\
281.9 \\
395.8 \\
508.8 \\
605.4 \\
636.8 \\
620.2 \\
652.2\end{array}$ & $\begin{array}{l}\text { ASSUMPIIONS SETS } \\
\text { SET } 3 \\
148.1 \\
183.4 \\
234.2 \\
281.8 \\
395.2 \\
499.5 \\
585.0 \\
623.2 \\
620.2 \\
652.2\end{array}$ & SETS \\
\hline $\begin{array}{c}T 0 \quad 1975 \\
0 \% \\
5 \% \\
10 \% \\
15 \%\end{array}$ & $\begin{array}{l}\text { DISCOUNTED } \\
55177.8 \\
6827.2 \\
2626.1 \\
1573.6\end{array}$ & $\begin{array}{l}\text { PRESENT VALUE } \\
51769.7 \\
6680.7 \\
2614.8 \\
1572.3\end{array}$ & $\begin{array}{l}\text { E OF CUM. SYSTEM COST } \\
51086.2 \\
6616.9 \\
2606.5 \\
1570.8\end{array}$ & \\
\hline $\begin{array}{c}10 \underset{0}{1995} \\
0 \% \\
5 \% \\
10 \% \\
15 \%\end{array}$ & $\begin{array}{r}50570.1 \\
10641.8 \\
4928.8 \\
3174.0\end{array}$ & $\begin{array}{r}47162.0 \\
10253.0 \\
4852.3 \\
3152.8\end{array}$ & $\begin{array}{r}46478.9 \\
10084.3 \\
4797.1 \\
3130.2\end{array}$ & \\
\hline $\begin{array}{c}\text { T0 } 2010 \\
0 \% \\
5 \% \\
10 \% \\
15 \%\end{array}$ & $\begin{array}{r}44319.9 \\
12910.6 \\
6695.9 \\
4512.0\end{array}$ & $\begin{array}{r}40919.1 \\
12110.5 \\
6386.0 \\
4349.7\end{array}$ & $\begin{array}{r}40267.3 \\
11797.8 \\
6201.9 \\
4224.9\end{array}$ & \\
\hline $\begin{array}{c}T 0 \underset{2020}{20} \\
0 \% \\
5 \% \\
10 \% \\
15 \%\end{array}$ & $\begin{array}{r}38574.3 \\
13513.7 \\
7479.5 \\
5193.1\end{array}$ & $\begin{array}{r}35327.5 \\
12397.8 \\
6904.6 \\
4818.3\end{array}$ & $\begin{array}{r}34839.9 \\
12098.1 \\
6696.4 \\
4660.4\end{array}$ & \\
\hline
\end{tabular}

HEALTH \& ENVIRON - EMISSIONS \& EFFECTS

\begin{tabular}{|c|c|c|c|c|c|c|}
\hline $\begin{array}{l}\text { YEAR } \\
1975 \\
1980 \\
1985 \\
1990 \\
2000 \\
2010 \\
2020 \\
2040 \\
2060 \\
2075\end{array}$ & $\begin{array}{l}\text { POP EXP } \\
\text { E3 } \\
\text { MAN REM } \\
14.31 \\
46.17 \\
90.18 \\
171.72 \\
280.53 \\
383.40 \\
599.40 \\
745.20 \\
915.30 \\
915.30\end{array}$ & $\begin{array}{r}\text { KR-85 } \\
\text { E6 } \\
\text { CURIES } \\
13.04 \\
42.07 \\
82.16 \\
156.21 \\
252.64 \\
280.44 \\
226.32 \\
39.36 \\
14.76 \\
.00\end{array}$ & $\begin{array}{r}\text { TRIT } \\
\text { ES } \\
\text { CURIES } \\
4.66 \\
15.05 \\
29.39 \\
55.90 \\
90.57 \\
104.88 \\
102.15 \\
56.46 \\
59.56 \\
55.26\end{array}$ & $\begin{array}{c}\text { RAD WASTE } \\
\text { E3 } \\
\text { CU FI } \\
2.92 \\
9.41 \\
18.37 \\
34.93 \\
56.49 \\
62.70 \\
50.60 \\
8.80 \\
3.30 \\
.00\end{array}$ & $\begin{array}{r}\text { SPENT } \\
\text { BLANKE } \\
\text { E3 CU F1 } \\
0.00 \\
0.00 \\
0.00 \\
.55 \\
6.60 \\
154.00 \\
715.00 \\
1430.00 \\
1831.50 \\
1864.50\end{array}$ & $\begin{array}{l}\text { (SPARE) } \\
\\
0.00 \\
0.00 \\
0.00 \\
0.00 \\
0.00 \\
0.00 \\
0.00 \\
0.00 \\
0.00 \\
0.00\end{array}$ \\
\hline $\begin{array}{l}\text { YEAR } \\
1975 \\
1980 \\
1985 \\
1990 \\
2000 \\
2010 \\
2020 \\
2040 \\
2060 \\
2075\end{array}$ & $\begin{array}{c}\text { CO2 } \\
\text { E9 TONS } \\
5.67 \\
6.68 \\
7.99 \\
7.92 \\
7.91 \\
7.37 \\
6.40 \\
5.53 \\
5.17 \\
5.17\end{array}$ & $\begin{array}{c}\text { EO TONS } \\
8.32 \\
7.94 \\
8.41 \\
8.60 \\
9.28 \\
8.52 \\
8.81 \\
8.59 \\
8.42 \\
8.42\end{array}$ & $\begin{array}{c}\text { NOX } \\
\text { E6 TONS } \\
18.08 \\
21.39 \\
25.55 \\
25.36 \\
25.37 \\
23.98 \\
20.83 \\
18.10 \\
17.27 \\
17.27\end{array}$ & $\begin{array}{c}\text { S02 } \\
\text { E6 TONS } \\
14.12 \\
19.75 \\
26.26 \\
26.26 \\
26.52 \\
25.40 \\
23.04 \\
20.62 \\
18.82 \\
18.82\end{array}$ & $\begin{array}{c}\text { PART } \\
\text { E6 TONS } \\
8.36 \\
18.27 \\
28.86 \\
29.14 \\
30.04 \\
29.54 \\
27.51 \\
24.79 \\
21.03 \\
21.03\end{array}$ & $\begin{array}{c}\text { HC } \\
\text { E6 TONS } \\
2.73 \\
2.74 \\
2.93 \\
2.86 \\
2.79 \\
2.37 \\
2.31 \\
2.15 \\
2.01 \\
2.01\end{array}$ \\
\hline $\begin{array}{l}\text { YEAR } \\
1975 \\
1980 \\
1985 \\
1990 \\
2000 \\
2010 \\
2020 \\
2040 \\
2060 \\
2075\end{array}$ & $\begin{array}{c}\text { LAND USE } \\
\text { E6 ACRES } \\
14.17 \\
19.20 \\
24.80 \\
28.79 \\
35.92 \\
41.51 \\
47.05 \\
48.90 \\
48.98 \\
48.98\end{array}$ & $\begin{array}{c}\text { DEAIHS } \\
\text { E3 } \\
1.14 \\
2.16 \\
3.06 \\
3.14 \\
3.36 \\
3.48 \\
2.79 \\
2.23 \\
2.05 \\
2.05\end{array}$ & $\begin{array}{c}\text { INJURIES } \\
\text { E3 } \\
26.12 \\
46.80 \\
66.42 \\
70.45 \\
80.36 \\
88.42 \\
76.26 \\
65.75 \\
64.39 \\
64.28\end{array}$ & $\begin{array}{c}\text { MAN DAYS } \\
\text { LDST E6 } \\
1.71 \\
3.13 \\
4.45 \\
4.66 \\
5.18 \\
5.58 \\
4.70 \\
3.95 \\
3.79 \\
3.79\end{array}$ & $\begin{array}{c}\text { SOLID WASTE } \\
\text { E9 TONS } \\
.20 \\
.29 \\
.37 \\
.39 \\
.46 \\
.50 \\
.36 \\
.25 \\
.27 \\
.27\end{array}$ & \\
\hline
\end{tabular}

Figure D-11. Continued. 
ALL SOLAR LONC FAMEE SUPPLY (RASED ON MZOJ)

$$
\text { FOSSIL RESOURCES }
$$

$\begin{array}{cc}\text { YEAR } & \text { LIO } 8 \text { GAS } \\ 1975 & 52.80 \\ 1980 & 49.98 \\ 1985 & 49.45 \\ 1990 & 45.95 \\ 2000 & 39.79 \\ 2010 & 27.14 \\ 2020 & 26.11 \\ 2040 & 23.36 \\ 2060 & 20.29 \\ 2075 & 20.29\end{array}$

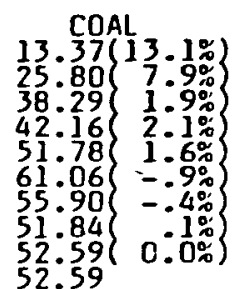

ELECIRIC GENERATION

$\begin{array}{lrrr}\text { I.IO } 8 \text { GAS } & \text { COAL } & \text { FISSION } & \text { CTR } \\ 6.48 & 8.82 & 1.65 & 0.00 \\ 6.98 & 13.03 & 5.34 & 0.00 \\ 6.70 & 14.86 & 10.12 & 0.00 \\ 6.15 & 14.28 & 18.88 & 0.00 \\ 5.30 & 13.43 & 28.53 & 0.00 \\ 5.00 & 12.31 & 31.58 & 0.00 \\ 4.71 & 4.86 & 24.95 & 0.00 \\ 4.36 & 0.00 & 4.33 & 0.00 \\ 4.36 & 0.00 & 1.62 & 0.00 \\ 4.36 & 0.00 & .00 & .03\end{array}$

\section{ELECTRICAL GENERATION}

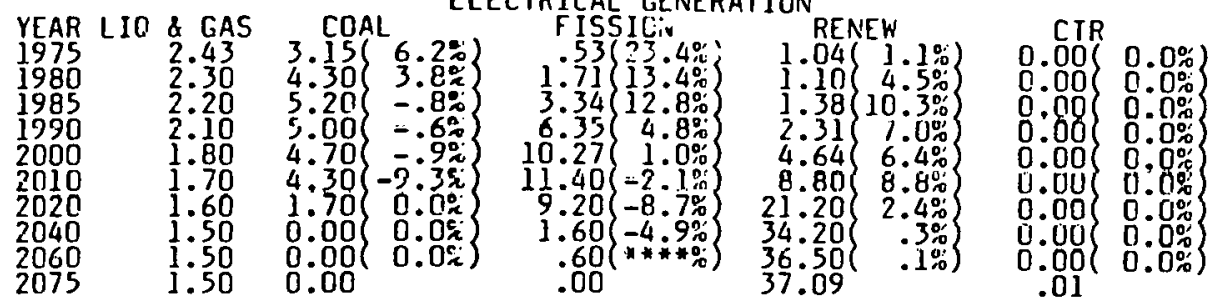

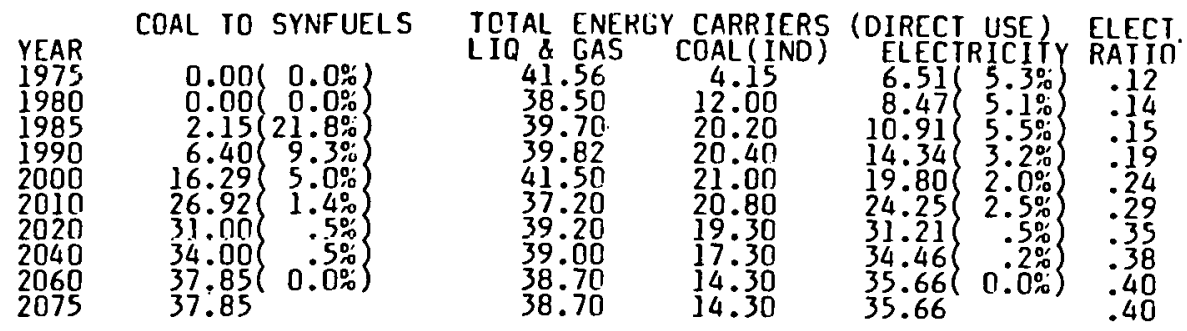

FINAL CONSUMPTION END USE

$\begin{array}{lr}Y E A R & k \\ 1975 & 13.2 \\ 1980 & 10.2 \\ 1985 & 8.2 \\ 1990 & 7.5 \\ 2010 & 6.9 \\ 2010 & 5.8 \\ 2020 & 6.02 \\ 2040 & 5.8 \\ 2060 & 5.8 \\ 2075 & 5.8\end{array}$

LIO \& GAS

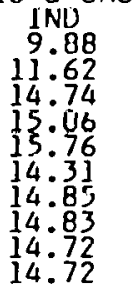

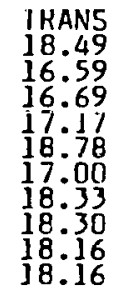

IRANS
18.49
16.59
16.69
17.11
$18: 78$
17.00
18.33
18.30
18.16
18.16

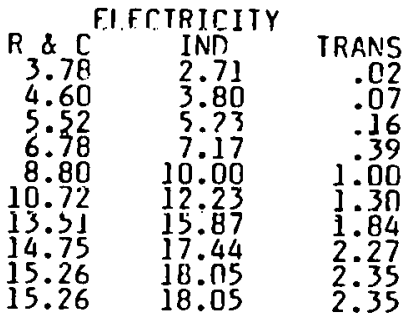

IOTALS

\begin{tabular}{|c|c|c|c|c|c|}
\hline $\begin{array}{l}\text { YCAR } \\
1975 \\
1980 \\
1985 \\
1990 \\
2000 \\
2010 \\
2020 \\
2040 \\
2060 \\
20175\end{array}$ & $\begin{array}{l}R \& C \\
16.98 \\
14.89 \\
13.79 \\
14.38 \\
15.76 \\
16.61 \\
19.53 \\
20.61 \\
21.08\end{array}$ & $\begin{array}{l}\text { IND } \\
16.73 \\
27.47 \\
40.17 \\
42.63 \\
46.76 \\
47.34 \\
50.02 \\
49.57 \\
47.07 \\
47.07\end{array}$ & $\begin{array}{l}\text { TRANS } \\
18.51 \\
16.66 \\
16.85 \\
17.56 \\
19.78 \\
18.30 \\
20.17 \\
20.57 \\
20.51\end{array}$ & $\begin{array}{l}\text { TU1 USE } \\
52.22 \\
58.97 \\
70.81 \\
74.57 \\
82.30 \\
82.25 \\
89.72 \\
90.75 \\
0196\end{array}$ & $\left.\begin{array}{r}10 T \text { RESO } \\
7 U .94 \\
84.26 \\
101.49 \\
113.59 \\
133.36 \\
144.92 \\
167.53 \\
177.24 \\
178.79\end{array}\right\}$ \\
\hline
\end{tabular}

$$
\begin{array}{cccc} 
& \multicolumn{4}{c}{\text { CUN. RESOURCE USE }} \\
& 1975-2024 & 1995-2044 & 1975-2075 \\
\text { IOTAL COAL } & 2344 . & 2719 . & 5012 . \\
\text { TOTAI. IIS \& RAS } & 1911: & 1432 . & 3043 .
\end{array}
$$

Figure D-12. Energy activity levels national annual totals (E15 Btu). 
IOTAL ANNLIAL SYSTEM COST (E9 DOLLARS)

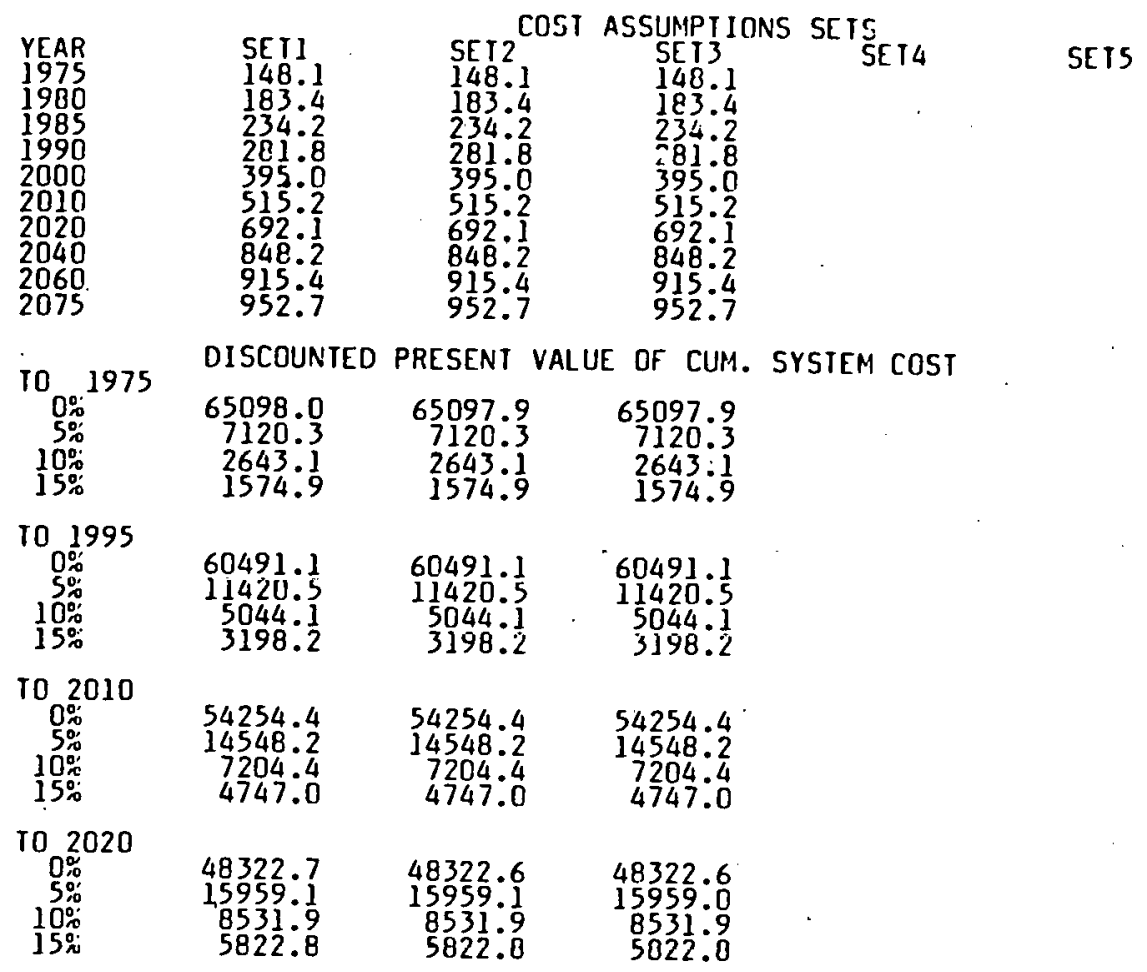

HEALIH \& ENVIRON - EMISSION'S \& EFFECTS

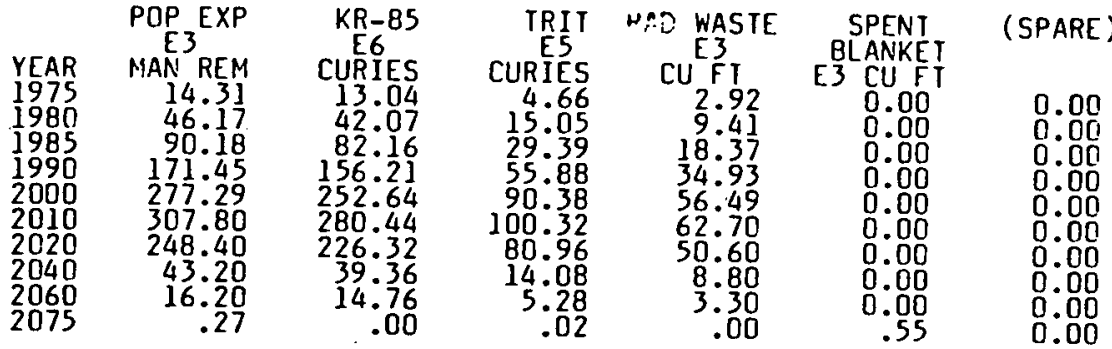

\begin{tabular}{|c|c|c|c|c|c|c|}
\hline $\begin{array}{l}\text { YEAR } \\
1975 \\
1900 \\
1985 \\
1990 \\
2000 \\
2010 \\
2020 \\
2040 \\
2060 \\
2075\end{array}$ & $\begin{array}{c}\text { CO2 } \\
\text { E9 TONS } \\
5.67 \\
6.60 \\
7.99 \\
7.92 \\
7.91 \\
7.37 \\
6.40 \\
5.53 \\
5.17 \\
5.17\end{array}$ & $\begin{array}{c}\text { CO } \\
\text { E6 TONS } \\
8.32 \\
7.34 \\
8.41 \\
8.60 \\
9.28 \\
8.52 \\
8.81 \\
8.59 \\
8.42 \\
8.42\end{array}$ & $\begin{array}{c}\text { NOX } \\
\text { E6 TONS } \\
18.08 \\
21.39 \\
25.55 \\
25.36 \\
25.37 \\
23.98 \\
20.83 \\
18.10 \\
17.27 \\
17.27\end{array}$ & $\begin{array}{c}\text { S02 } \\
\text { E6 TONS } \\
14.12 \\
19.75 \\
26.26 \\
26.26 \\
26.52 \\
25.40 \\
23.04 \\
20.62 \\
18.82 \\
18.82\end{array}$ & $\begin{array}{c}\text { PART } \\
\text { E6 TONS } \\
8.36 \\
18.27 \\
28.86 \\
29.14 \\
30.04 \\
29.54 \\
27.51 \\
24.79 \\
21.03 \\
21.03\end{array}$ & $\begin{array}{c}\text { HC } \\
\text { E6 TONS } \\
2.73 \\
2.74 \\
2.93 \\
2.86 \\
2.79 \\
2.37 \\
2.31 \\
2.15 \\
2.01 \\
2.01\end{array}$ \\
\hline $\begin{array}{l}\text { YEAR } \\
1975 \\
1980 \\
1985 \\
1990 \\
2000 \\
2010 \\
2020 \\
2040 \\
2060\end{array}$ & $\begin{array}{l}\text { LAND. USE } \\
\text { E.6 AC.RES } \\
14.17 \\
19.20 \\
24.80 \\
28.80 \\
35.94 \\
42.01 \\
49.39 \\
53.58 \\
54.97 \\
55.08\end{array}$ & $\begin{array}{c}\text { DEATHS } \\
\text { E3 } \\
1.14 \\
2.16 \\
3.06 \\
3.14 \\
3.36 \\
3.48 \\
2.79 \\
2.22 \\
2.05 \\
2.04\end{array}$ & $\begin{array}{c}\text { INJURIES } \\
\text { E3 } \\
26.12 \\
46.80 \\
66.42 \\
70.45 \\
80.36 \\
88.38 \\
76.04 \\
65.31 \\
63.82 \\
63.70\end{array}$ & $\begin{array}{c}\text { MAN DAYS } \\
\text { LOST E6 } \\
1.71 \\
3.13 \\
4.45 \\
4.66 \\
5.18 \\
5.58 \\
4.69 \\
3.94 \\
3.78 \\
3.78\end{array}$ & $\begin{array}{c}\text { SOLID WASTE } \\
\text { E9 TONS } \\
.20 \\
.29 \\
.37 \\
.39 \\
.46 \\
.50 \\
.36 \\
.25 \\
.27\end{array}$ & \\
\hline
\end{tabular}

Figure D-12. Continued. 
MZ03 ALL FBP. LONG RANGE SUPPLY (BASED ON MZO1)

FOSSIL RESOURCES
TOTAL USE

$\begin{array}{cc}\text { YEAR } & \text { LIQ \& CAS } \\ 1975 & 52.80 \\ 1980 & 49.98 \\ 1985 & 49.45 \\ 1990 & 45.95 \\ 2000 & 39.79 \\ 2010 & 27.14 \\ 2020 & 26.11 \\ 2040 & 23.36 \\ 2060 & 20.29 \\ 2075 & 20.29\end{array}$

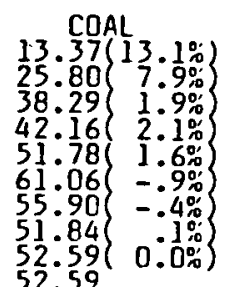

ELECTRIC GENERATION RESOURCE USE (THERMAL)

$\begin{array}{cccc}\text { LIO \& GAS } & \text { COAL } & \text { FISSION } & \text { CTR } \\ 6.48 & 8.82 & 1.65 & 0.00 \\ 6.98 & 13.03 & 5.34 & 0.00 \\ 6.70 & 14.86 & 10.12 & 0.00 \\ 6.15 & 14.28 & 18.91 & 0.00 \\ 5.30 & 13.43 & 31.64 & 0.00 \\ 5.00 & 12.31 & 47.65 & 0.00 \\ 4.71 & 4.86 & 73.77 & 0.00 \\ 4.36 & 0.00 & 88.22 & 0.00 \\ 4.36 & 0.00 & 91.53 & 0.00 \\ 4.36 & 0.00 & 67.80 & .00\end{array}$

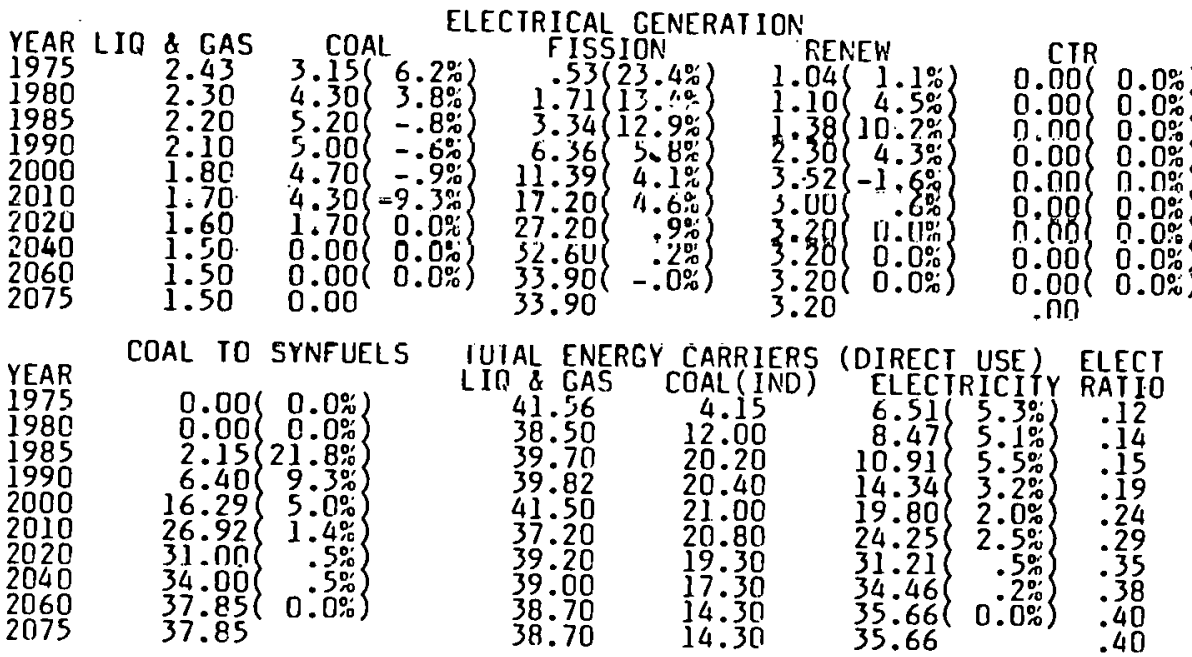

FINAL CONSUMPIION END USE

$\begin{array}{lr}\text { YCAR } & R \& L \\ 1975 & 13.20 \\ 1980 & 10.29 \\ 1985 & 8.27 \\ 1990 & 7.59 \\ 2000 & 6.96 \\ 2010 & 5.89 \\ 2020 & 6.02 \\ 2040 & 5.86 \\ 2060 & 5.82 \\ 2075 & 5.82\end{array}$

LIQ \& GAS

$\begin{array}{ll}R \& L & 1 N D \\ 13.20 & 9.88 \\ 10.29 & 11.62 \\ 8.27 & 14.74 \\ 7.59 & 15.06 \\ 6.96 & 15.76 \\ 5.89 & 14.31 \\ 6.02 & 14.85 \\ 5.86 & 14.83 \\ 5.82 & 14.72 \\ 5.82 & 14.72\end{array}$

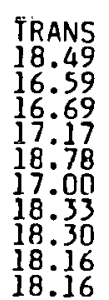

TRANS
18.49
16.59
16.69
17.17
18.78
17.00
18.33
18.30
18.16
18.16

TOTALS

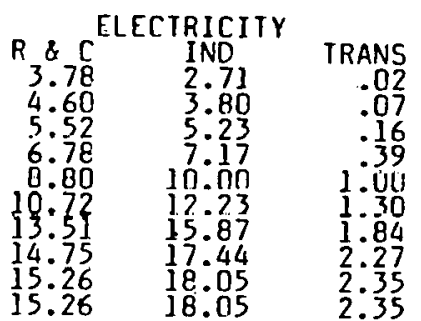

$15.26 \quad 18.05$

RANS
.02
.07
116
$: 39$
1.001
1.30
1.84
2.87
2.35
2.35

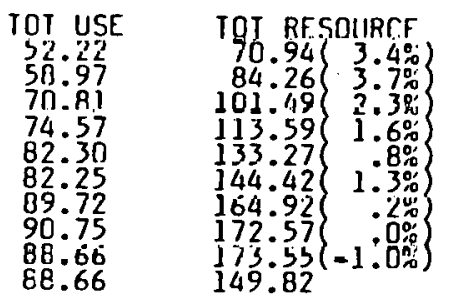

\begin{tabular}{|c|c|c|c|c|c|}
\hline $\begin{array}{l}\text { YEAR } \\
1975 \\
1980 \\
1985 \\
1990 \\
2000 \\
2010 \\
2020 \\
2040 \\
2060 \\
2075\end{array}$ & $\begin{array}{l}R \& C \\
16.98 \\
14.89 \\
13.79 \\
14.38 \\
15.76 \\
16.61 \\
19.53 \\
20.61 \\
21.08 \\
21.08\end{array}$ & $\begin{array}{l}\text { IND } \\
16.73 \\
27.42 \\
40.17 \\
42.63 \\
46.76 \\
47.34 \\
50.02 \\
49.57 \\
47.07 \\
47.07\end{array}$ & $\begin{array}{l}\text { IRANS } \\
18.51 \\
16.66 \\
16.85 \\
19.56 \\
19.78 \\
18.30 \\
20.17 \\
20.57 \\
20.51 \\
20.51\end{array}$ & $\begin{array}{l}\text { TOT USE } \\
32.22 \\
58.97 \\
70.81 \\
74.57 \\
82.30 \\
82.25 \\
89.72 \\
90.75 \\
88.66 \\
88.66\end{array}$ & 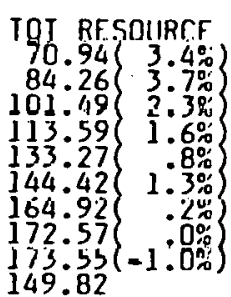 \\
\hline
\end{tabular}

Figure D-13. Energy activity levels national annual totals (E15 Btu). 
TOTAL ANNUAL SYSTEP COST (E9 DOLLARS)

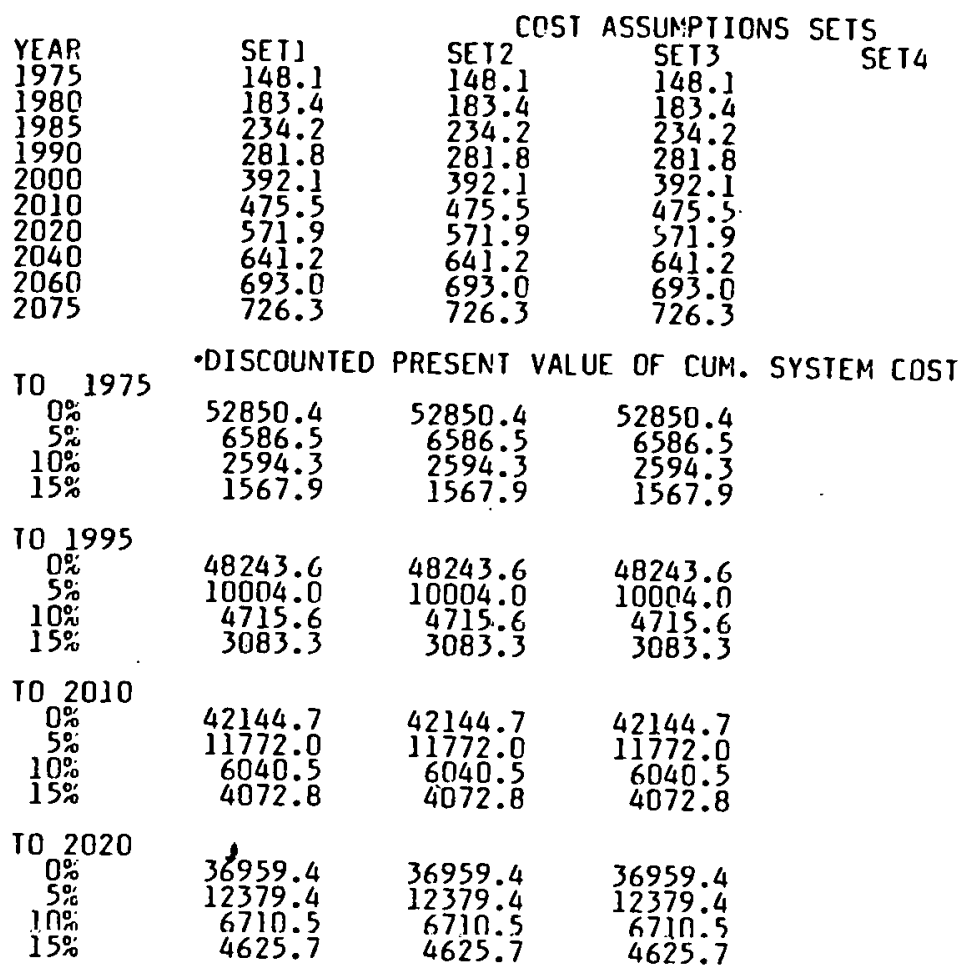

HEALTH \& ENVIRON - EMISSIONS \& EFFECIS

\begin{tabular}{|c|c|c|c|c|c|c|}
\hline $\begin{array}{l}\text { YEAR } \\
1975 \\
1980 \\
1985 \\
1990 \\
2000 \\
2010 \\
2020 \\
2040 \\
2060 \\
2075\end{array}$ & $\begin{array}{l}\text { POP EXP } \\
\text { E3 } \\
\text { MAN REM } \\
14.31 \\
46.17 \\
90.18 \\
171.72 \\
307.53 \\
464.40 \\
734.40 \\
880.20 \\
915.30 \\
915.30\end{array}$ & $\begin{array}{c}\text { KR-85 } \\
\text { E6 } \\
\text { CURIES } \\
13.04 \\
42.07 \\
82.16 \\
156.46 \\
280.19 \\
423.12 \\
669.12 \\
801.96 \\
833.94 \\
833.92\end{array}$ & $\begin{array}{r}\text { IRIT } \\
\text { E5 } \\
\text { CURIES } \\
4.66 \\
15.05 \\
29.39 \\
55.97 \\
100.23 \\
151.36 \\
239.36 \\
286.88 \\
298.32 \\
298.31\end{array}$ & $\begin{array}{c}\text { RAD WASTE } \\
\text { E3 } \\
\text { CUFT } \\
2.92 \\
9.41 \\
18.37 \\
34.98 \\
62.65 \\
94.60 \\
149.60 \\
179.30 \\
186.45 \\
186.44\end{array}$ & $\begin{array}{r}\text { SPENT } \\
\text { BLANKET } \\
\text { E3 CU FT } \\
0.00 \\
0.00 \\
0.00 \\
0.00 \\
0.00 \\
0.00 \\
0.00 \\
0.00 \\
0.00 \\
.05\end{array}$ & $\begin{array}{l}0.00 \\
0.00 \\
0.00 \\
0.00 \\
0.00 \\
0.00 \\
0.00 \\
0.00 \\
0.00 \\
0.00\end{array}$ \\
\hline $\begin{array}{l}\text { YEAR } \\
1975 \\
1980 \\
19.85 \\
1990 \\
2000 \\
2010 \\
2020 \\
2040 \\
2060 \\
2075\end{array}$ & $\begin{array}{c}\text { CO2 } \\
\text { IONS } \\
5.67 \\
6.68 \\
7.99 \\
7.92 \\
7.91 \\
7.37 \\
6.40 \\
5.53 \\
5.17 \\
5.17\end{array}$ & $\begin{array}{c}\text { EO } 6 \text { TONS } \\
8.32 \\
7.94 \\
8.41 \\
8.60 \\
9.28 \\
8.52 \\
8.81 \\
8.59 \\
8.42 \\
8.42 .\end{array}$ & $\begin{array}{l}\text { NOX } \\
\text { E6 TONS } \\
18.08 \\
21.39 \\
25.55 \\
25.36 \\
25.38 \\
23.99 \\
20.86 \\
18.14 \\
17.31 \\
17.31\end{array}$ & $\begin{array}{c}\text { SO2 } \\
\text { E6 IONS } \\
11.12 \\
19.75 \\
26.26 \\
26.26 \\
26.52 \\
25.40 \\
23.04 \\
20.62 \\
18.82 \\
18.82\end{array}$ & $\begin{array}{c}\text { PART } \\
\text { E6 TONS } \\
8.36 \\
18.27 \\
28.86 \\
29.34 \\
30.04 \\
29.55 \\
27.52 \\
24.81 \\
21.05 \\
21.05\end{array}$ & $\begin{array}{c}\text { HC } \\
\text { E6 TONS } \\
2.73 \\
2.74 \\
2.93 \\
2.86 \\
2.79 \\
2.37 \\
2.31 \\
2.15 \\
2.01 \\
2.01\end{array}$ \\
\hline $\begin{array}{l}\text { YEAR } \\
1975 \\
1980 \\
1985 \\
1990 \\
2000 \\
2010 \\
2020 \\
2040 \\
2060\end{array}$ & $\begin{array}{l}\text { LAND USE } \\
\text { E6 ACRES } \\
14.17 \\
19.20 \\
24.80 \\
28.79 \\
35.74 \\
40.97 \\
46.15 \\
48.00 \\
48.98 \\
48.98\end{array}$ & $\begin{array}{c}\text { DEATHS } \\
\text { E3 } \\
1.14 \\
2.16 \\
3.06 \\
3.14 \\
3.36 \\
3.51 \\
2.90 \\
2.42 \\
2.26 \\
2.26\end{array}$ & $\begin{array}{c}\text { INJURIES } \\
\text { E3 } \\
26.12 \\
46.80 \\
66.42 \\
70.45 \\
80.58 \\
89.54 \\
79.64 \\
71.51 \\
70.48 \\
70 . .18\end{array}$ & $\begin{array}{c}\text { MAN DAYS } \\
\text { LOSTE6 } \\
1.71 \\
3.13 \\
4.45 \\
4.66 \\
5.20 \\
5.65 \\
4.90 \\
4.29 \\
4.16 \\
4.16\end{array}$ & $\begin{array}{c}\text { SOL ID WASTE } \\
\text { E9 TONS } \\
.20 \\
.29 \\
.37 \\
.39 \\
.46 \\
.52 \\
.42 \\
.35 \\
.38 \\
.38\end{array}$ & \\
\hline
\end{tabular}

Figure D-13. Continued. 
HHOI IMHORTS ALLOWED, HIGH FUSION

$$
\begin{aligned}
& \text { FOSSIL RESOURCES } \\
& \text { TOTAL USE }
\end{aligned}
$$

ELECTRIC GENERATION

$\begin{array}{cc}\text { YEAR } & \text { LIQ } \& \text { GAS } \\ 1975 & 52.80 \\ 1980 & 58.66 \\ 1985 & 66.50 \\ 1990 & 66.80 \\ 2000 & 65.90 \\ 2010 & 63.20 \\ 2020 & 63.10 \\ 2040 & 63.10 \\ 2060 & 63.10 \\ 2075 & 63.10\end{array}$

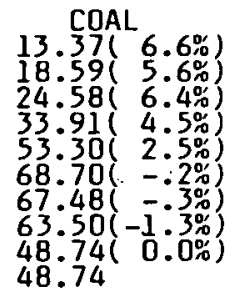

LIO RESOURCE USE (THERMAL)
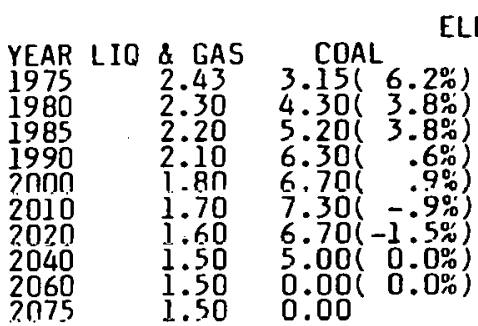

ELECTRICAL GENERATION

\begin{tabular}{lrrr} 
GAS & COAL & FISSION & \multicolumn{1}{c}{ CTR } \\
6.48 & 8.82 & 1.65 & 0.00 \\
6.98 & 13.03 & 5.34 & 0.00 \\
6.70 & 14.86 & 11.33 & 0.00 \\
6.15 & 18.00 & 23.94 & .03 \\
5.30 & 19.14 & 28.53 & .34 \\
5.00 & 20.90 & 31.58 & 2.29 \\
4.71 & 19.14 & 24.95 & 17.14 \\
4.36 & 14.31 & 4.33 & 64.29 \\
4.36 & 0.00 & 1.62 & 140.00 \\
4.36 & 0.00 & .00 & 178.86
\end{tabular}

COAL TO SYNFUELS
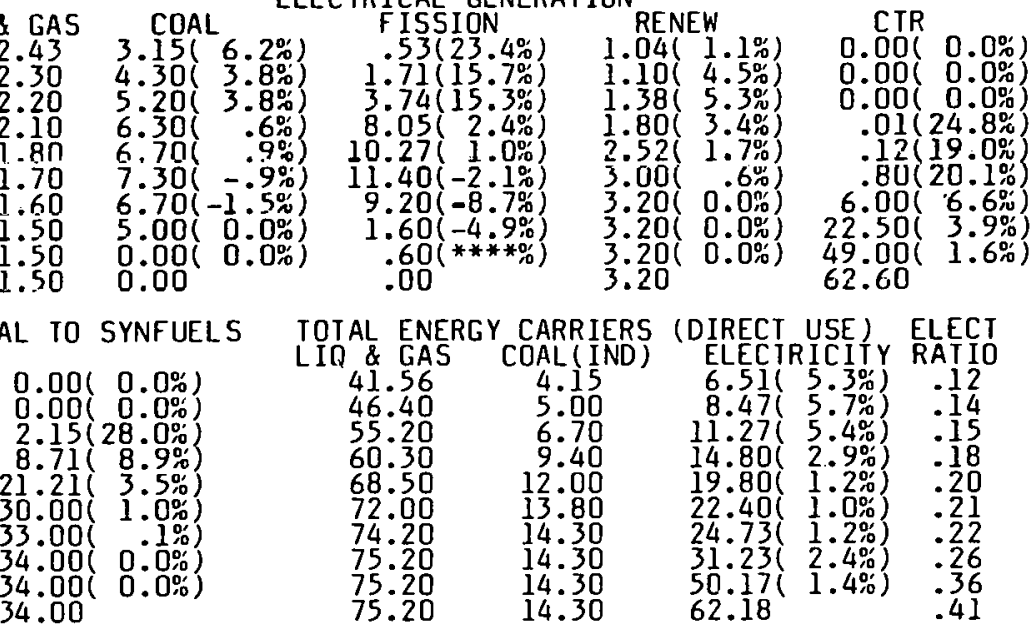

YEAR
1975
1980
1985
1990
2000
2010
2020
2040
2060
2075

LIT

$\begin{array}{cc}\text { TAL } & \text { ENERGY CARR IERS } \\ \text { Q \& GAS } & \text { COAL (IND) } \\ 41.56 & 4.15 \\ 46.40 & 5.00 \\ 55.20 & 6.70 \\ 60.30 & 9.40 \\ 68.50 & 12.00 \\ 72.00 & 13.80 \\ 74.20 & 14.30 \\ 75.20 & 14.30 \\ 75.20 & 14.30 \\ 75.20 & 14.30\end{array}$

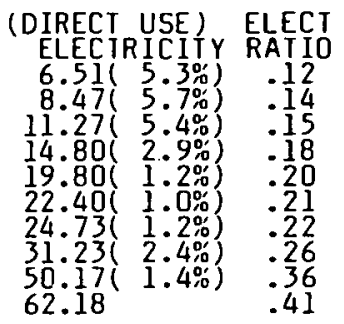

FINAL CONSUMPTION END USE

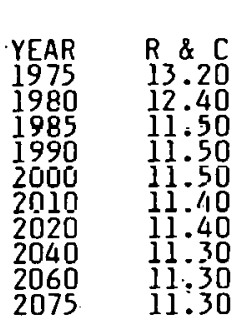

LID \& GAS
IND
9.88
14.00
20.50
22.80
26.00
27.70
28.10
28.60
28.60
28.60
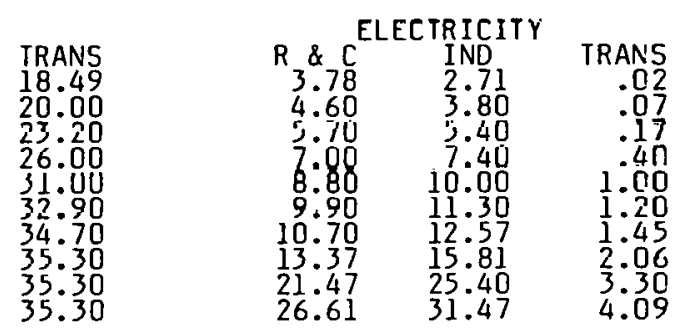

TOTALS

\begin{tabular}{|c|c|c|c|c|c|}
\hline $\begin{array}{l}\text { YFAR } \\
1975 \\
1980 \\
1985 \\
1990 \\
2000 \\
2010 \\
2020 \\
2040 \\
2060 \\
2075\end{array}$ & $\begin{array}{l}R \& r \\
16.98 \\
17.00 \\
17.20 \\
18.50 \\
20.30 \\
21.30 \\
22.10 \\
24.67 \\
32.77\end{array}$ & $\begin{array}{l}\text { INO } \\
16.73 \\
22.80 \\
32.80 \\
39.60 \\
48.00 \\
52.80 \\
54.97 \\
58.71 \\
68.30 \\
74.37\end{array}$ & $\begin{array}{l}\text { TRANS } \\
18.51 \\
20.17 \\
23.37 \\
26.40 \\
32.00 \\
34.10 \\
36.15 \\
37.36 \\
38.60 \\
39\end{array}$ & $\begin{array}{l}\text { TOI USE } \\
52.22 \\
59.97 \\
73.37 \\
84.50 \\
100.30 \\
108.20 \\
113.22 \\
120.74 \\
139.67 \\
151.67\end{array}$ & $\begin{array}{r}\text { TOT RES } \\
70.94 \\
85.73( \\
106.04 \\
129.82 \\
155.27 \\
174.37 \\
181.81 \\
204.36 \\
262.601 \\
299.84\end{array}$ \\
\hline
\end{tabular}

$$
\begin{array}{cccc} 
& \text { CUM RESOURCE USE } & \\
& 1975-2024 & 1995-2044 & 1975-2075 \\
\text { IOIAL COAL } & 2386 . & 3168 . & 5263 . \\
\text { TOTAL LIQ \& GAS } & 3176 . & 3187 . & 6395 .
\end{array}
$$

Figure D-14. Energy activity levels national annual totals (EI5 Btu). 
IOTAL ANNUAL SYSTEM COSI (E9 DOLLARS)

$\begin{array}{llll}\text { YEAR } & \text { SETI } & \text { COST ASSUMPIIONS SETS } \\ 1975 & 148.1 & 148.1 & \text { SET3 } \\ 1980 & 191.5 & 191.5 & 148.1 \\ 1985 & 254.2 & 254.2 & 191.5 \\ 1990 & 333.8 & 333.8 & 254.2 \\ 2000 & 462.5 & 462.5 & 333.7 \\ 2010 & 579.3 & 578.2 & 461.9 \\ 2010 & 661.2 & 644.6 & 575.5 \\ 2040 & 810.7 & 750.5 & 635.2 \\ 2060 & 989.0 & 898.2 & 838.8 \\ 2075 & 1078.0 & 1034.9 & 1034.2\end{array}$

SEIS

T0 1975

DISCOUNTED PRESENT VALUE OF CUM. SYSTEM COST

$\begin{array}{rrrr}0 \% & 67749.8 & 64166.1 & 63764.9 \\ 5 \% & 7661.4 & 7548.4 & 7515.9 \\ 10 \% & 2880.3 & 2873.6 & 2869.6 \\ 15 \% & 1692.9 & 1692.3 & 1691.6\end{array}$

TO 1995

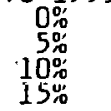

$\begin{array}{lll}62608.6 & 59024.9 & 58624.8 \\ 12131.8 & 11831.9 & 11746.9\end{array}$ $\begin{array}{rrr}5628.4 & 5583.1 & 5557.5 \\ 3612.7 & 3662.2 & 3651.7\end{array}$

TO 2010

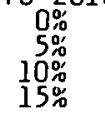

$$
\begin{array}{rrr}
55325.0 & 51742.9 & 51352.8 \\
14457.2 & 13835.5 & 13672.7 \\
7240.4 & 7053.0 & 6967.4 \\
4865.9 & 4782.5 & 4729.1
\end{array}
$$

$\begin{array}{crrr}\text { TO } 2020 & & & \\ 0 \% & 49126.0 & 45606.5 & 45280.6 \\ 5 \% & 15407.7 & 14469.8 & 14285.3 \\ 10 \% & 8027.5 & 7632.5 & 7512.3 \\ 15 \% & 5433.9 & 5206.7 & 5119.7\end{array}$

\begin{tabular}{|c|c|c|c|c|c|c|}
\hline $\begin{array}{l}\text { YEAR } \\
1975 \\
1980 \\
1985 \\
1990 \\
2000 \\
2010 \\
2020 \\
2040 \\
2060\end{array}$ & $\begin{array}{l}\text { POP EXP } \\
\text { E3 } \\
\text { MAN REM } \\
14.31 \\
46.17 \\
100.98 \\
217.62 \\
280.53 \\
329.40 \\
410.40 \\
650.70 \\
1339.20 \\
1690.20\end{array}$ & $\begin{array}{c}\text { KR-85 } \\
\text { E6 } \\
\text { CURIES } \\
13.04 \\
42.07 \\
92.00 \\
198.03 \\
252.64 \\
280.44 \\
226.32 \\
39.36 \\
14.76 \\
.00 .\end{array}$ & $\begin{array}{r}\text { TRIT } \\
\text { ES } \\
\text { CURIES } \\
4.66 \\
15.05 \\
32.91 \\
70.86 \\
90.57 \\
101.62 \\
90.74 \\
50.76 \\
85.15 \\
102.04\end{array}$ & $\begin{array}{c}\text { RAD WASTE } \\
\text { E3 } \\
\text { CU FT } \\
2.92 \\
9.41 \\
20.57 \\
44.28 \\
56.49 \\
62.70 \\
50.60 \\
8.80 \\
3.30 \\
.00\end{array}$ & $\begin{array}{r}\text { SPENT } \\
\text { BLANKET } \\
\text { E3 CU F } \\
0.00 \\
0.00 \\
0.00 \\
.55 \\
6.60 \\
44.00 \\
330.00 \\
1237.50 \\
2695.00 \\
3443.00\end{array}$ & $\begin{array}{l}0.00 \\
0.00 \\
0.00 \\
0.00 \\
0.00 \\
0.00 \\
0.00 \\
0.00 \\
0.00 \\
0.00\end{array}$ \\
\hline $\begin{array}{l}A R \\
75 \\
380 \\
85 \\
90 \\
000 \\
10 \\
20 \\
40 \\
60\end{array}$ & $\begin{array}{c}\text { CO2 } \\
\text { E9 TONS } \\
5.67 \\
6.53 \\
7.73 \\
8.80 \\
9.79 \\
10.46 \\
10.44 \\
9.88 \\
8.10 \\
8.10\end{array}$ & $\begin{array}{c}\text { CO } \\
\text { E6 TONS } \\
8.32 \\
9.10 \\
10.62 \\
11.99 \\
14.25 \\
15.21 \\
15.91 \\
16.03 \\
15.65 \\
15.65\end{array}$ & $\begin{array}{c}\text { NOX } \\
\text { E6 TONS } \\
18.08 \\
21.19 \\
25.42 \\
28.80 \\
31.90 \\
34.17 \\
33.92 \\
32.01 \\
26.07 \\
26.07\end{array}$ & $\begin{array}{l}\text { S02 } \\
\text { E6 TONS } \\
14.12 \\
16.91 \\
21.16 \\
24.56 \\
27.81 \\
30.12 \\
30.19 \\
29.19 \\
25.93 \\
25.93\end{array}$ & $\begin{array}{c}\text { PART } \\
\text { E6 TONS } \\
8.36 \\
9.96 \\
12.90 \\
16.77 \\
20.79 \\
23.49 \\
24.16 \\
24.03 \\
23.44 \\
23.44\end{array}$ & $\begin{array}{c}\text { HC } \\
\text { E6 TONS } \\
2.73 \\
3.02 \\
3.46 \\
3.71 \\
4.04 \\
4.15 \\
4.23 \\
4.21 \\
4.07 \\
4.07\end{array}$ \\
\hline $\begin{array}{l}5 A R \\
975 \\
980 \\
985 \\
990 \\
000 \\
10 \\
20 \\
340 \\
160\end{array}$ & $\begin{array}{c}\text { LAND USE } \\
\text { E6 ACRES } \\
14.17 \\
18.01 \\
22.94 \\
30.96 \\
37.86 \\
43.93 \\
45.77 \\
51.04 \\
65.50 \\
77.07\end{array}$ & $\begin{array}{c}\text { DEATHS } \\
\text { E3 } \\
1.14 \\
1.58 \\
1.96 \\
2.36 \\
3.21 \\
3.95 \\
3.65 \\
3.22 \\
2.00 \\
1.99\end{array}$ & $\begin{array}{c}\text { INJURIES } \\
\text { E3 } \\
26.12 \\
35.51 \\
45.05 \\
57.56 \\
81.85 \\
101.75 \\
97.41 \\
88.45 \\
62.89 \\
63.00\end{array}$ & $\begin{array}{c}\text { MAN DAYS } \\
\text { LOST E6 } \\
1.71 \\
2.34 \\
2.94 \\
3.68 \\
5.15 \\
6.39 \\
6.04 \\
5.43 \\
3.69 \\
3.69\end{array}$ & $\begin{array}{c}\text { SOLID WASIE } \\
\text { E9 TONS } \\
.20 \\
.28 \\
.36 \\
.48 \\
.60 \\
.71 \\
.68 \\
.56 \\
.24 \\
.24\end{array}$ & \\
\hline
\end{tabular}

HEALTH \& ENVIRON - EMISSIONS \& EFFECTS

Figure D-14. Continued. 
HHO2 NO IMPORTS, VERY HIGH FUSION

FOSSIL RESOURCES

\& GAS

52.80

49.45

47.79

39.79

26.11

23.36

20.29

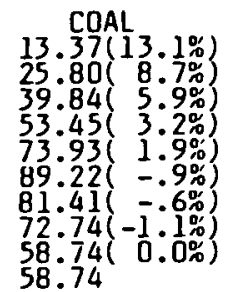

ELECIRIC GENERAIIDN RESOURCE USE (THERMAL)

LIO

$\begin{array}{lrrr}\text { 8. GAS } & \text { COAL } & \text { FISSION } & \text { CTR } \\ 6.48 & 8.82 & 1.65 & 0.00 \\ 6.98 & 13.03 & 5.34 & 0.00 \\ 6.70 & 14.86 & 11.33 & 0.00 \\ 6.15 & 18.00 & 23.94 & .03 \\ 5.30 & 19.14 & 28.53 & .034 \\ 5.00 & 20.90 & 31.58 & 8.00 \\ 4.71 & 19.14 & 24.95 & 40.00 \\ 4.36 & 14.31 & 4.33 & 94.29 \\ 4.36 & 0.00 & 1.62 & 172.29 \\ 4.36 & 0.00 & .00 & 212.57\end{array}$

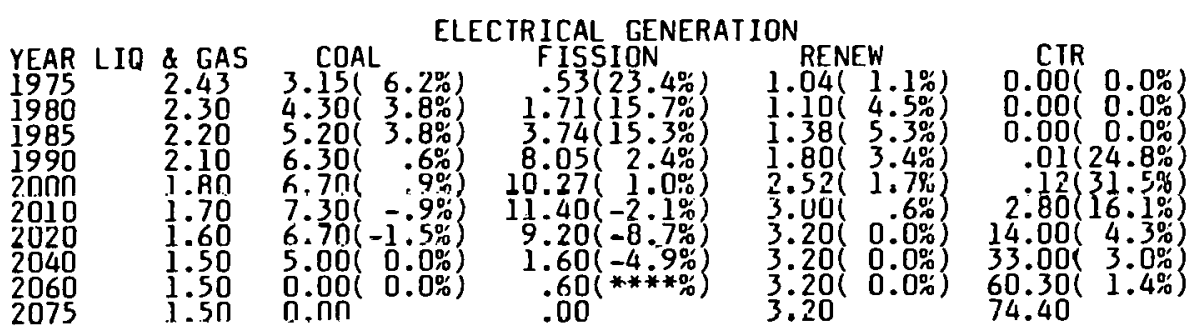

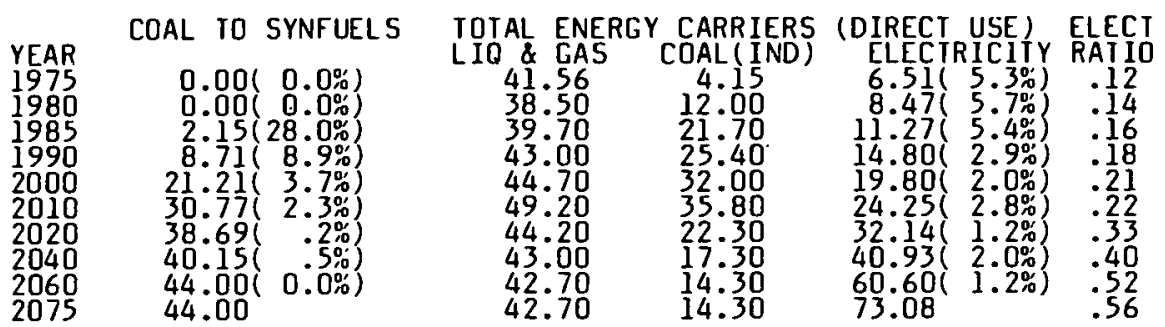

FINAL CONSUMPIION END USE

$\begin{array}{lccc} & & \text { LIQ } \$ \text { GAS } & \\ \text { YEAR } & \text { R \& C } & \text { IND } & \text { IRANS } \\ 1975 & 13.20 & 9.88 & 18.49 \\ 1980 & 10.29 & 11.62 & 16.59 \\ 1985 & 8.27 & 14.74 & 16.09 \\ 1990 & 0.20 & 16.26 & 18.54 \\ 2000 & 7.50 & 16.57 & 20.23 \\ 7010 & 7.79 & 18.92 & 20.19 \\ 2020 & 6.79 & 16.74 & 20.67 \\ 2040 & 6.46 & 16.35 & 20.18 \\ 2060 & 6.42 & 16.24 & 20.04 \\ 2075 & 6.42 & 16.24 & 20.04\end{array}$

$\begin{array}{rrr} & \text { ELECIRICLIY } \\ R \& C & \text { IND } & \text { TRANS } \\ 3.78 & 2.71 & 002 \\ 4.60 & 3.80 & .07 \\ 5.70 & 5.40 & .17 \\ 7.00 & 7.41 & .40 \\ 8.80 & 10.00 & 1.00 \\ 10.72 & 12.23 & 1.30 \\ 13.91 & 16.34 & 1.89 \\ 17.52 & 20.71 & 2.70 \\ 25.93 & 30.68 & 3.99 \\ 31.27 & 36.99 & 4.82\end{array}$

TOTALS

\begin{tabular}{|c|c|c|c|c|c|}
\hline $\begin{array}{l}\text { YEAR } \\
1975 \\
1980 \\
1985 \\
1990 \\
2000 \\
2010 \\
2020 \\
2040\end{array}$ & $\begin{array}{l}R \& C \\
16.98 \\
14.89 \\
13.97 \\
15.20 \\
16.30 \\
18.51 \\
20.70 \\
23.98 \\
32.35\end{array}$ & $\begin{array}{l}\text { IND } \\
16.73 \\
27.42 \\
41.84 \\
49.06 \\
58.97 \\
66.95 \\
55.38 \\
54.36 \\
61.22 \\
67.53\end{array}$ & $\begin{array}{l}\text { TRANS } \\
18.51 \\
16.66 \\
16.86 \\
18.94 \\
21.23 \\
23.79 \\
22.56 \\
22.88 \\
24.03\end{array}$ & $\begin{array}{r}\text { TOT USE } \\
52.22 \\
58.97 \\
72.67 \\
83.20 \\
96.50 \\
109.25 \\
98.64 \\
101.22 \\
117.60\end{array}$ & $\begin{array}{r}\text { TOT RES } \\
70.94( \\
84.26 \\
104.25( \\
130.351 \\
149.79( \\
174.99( \\
181.61 \\
203.863 \\
262.081 \\
300.74\end{array}$ \\
\hline
\end{tabular}

\section{5-2024 RESOURCE USE $1995-2044 \quad 1975-2075$ \\ $\begin{array}{llll}\text { IOIAL COAL } & 3194 . & 3917 . & 6571\end{array}$}

Figure D-15. Energy activity levels national annual totals (E15 Btu). 
TOTAL ANNUAL SYSTEM COST (E9 DOLLARS)

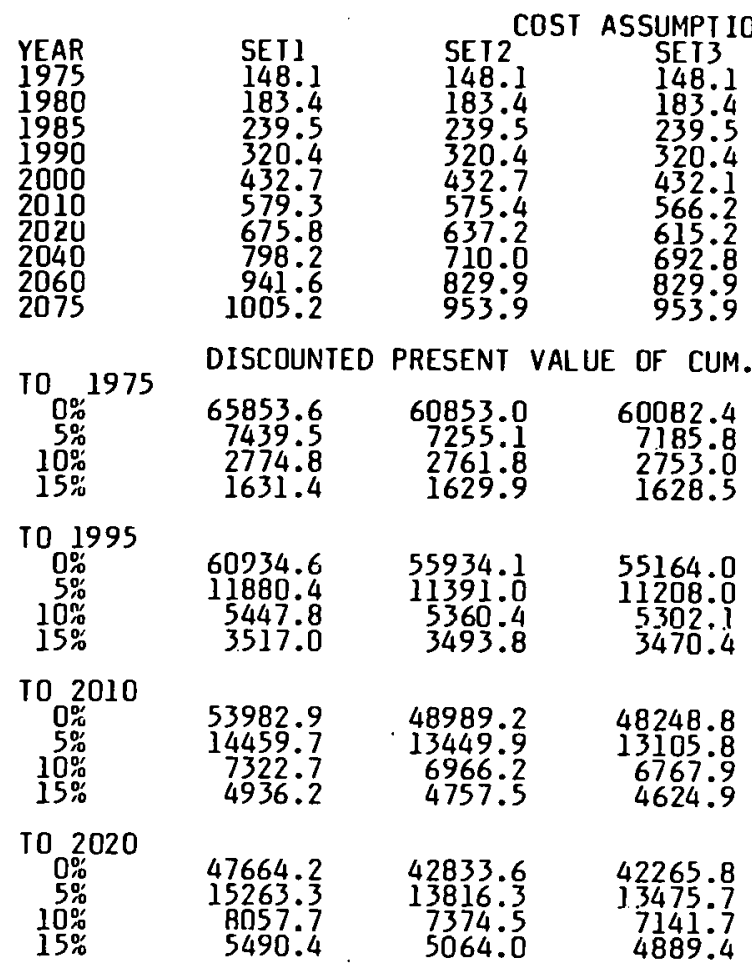

HEALTH \& ENVIRON - EMISSIONS \& EFFECTS

\begin{tabular}{|c|c|c|c|c|c|c|}
\hline $\begin{array}{l}\text { YEAR } \\
1975 \\
1980 \\
1985 \\
1990 \\
2000 \\
2010 \\
2020 \\
2040 \\
2060 \\
2075\end{array}$ & $\begin{array}{l}\text { POP EXP } \\
\text { E3 } \\
\text { MAN REM } \\
14.31 \\
46.17 \\
100.98 \\
217.62 \\
280.53 \\
383.40 \\
626.40 \\
934.20 \\
1644.30 \\
2008.80\end{array}$ & $\begin{array}{r}\text { KR-85 } \\
\text { E6 } \\
\text { CURIES } \\
13.04 \\
42.07 \\
92.00 \\
198.03 \\
252.64 \\
280.44 \\
226.32 \\
39.36 \\
14.76 \\
.00\end{array}$ & $\begin{array}{r}\text { TRIT } \\
\text { E5 } \\
\text { CURIES } \\
4.66 \\
15.05 \\
32.91 \\
70.86 \\
90.57 \\
104.88 \\
103.78 \\
67.87 \\
103.57 \\
121.27\end{array}$ & $\begin{array}{c}\text { RAD WASTE } \\
\text { E3 } \\
\text { CUFI } \\
2.92 \\
9.41 \\
20.57 \\
44.28 \\
56.49 \\
62.70 \\
50.60 \\
8.80 \\
3.30 \\
.00\end{array}$ & $\begin{array}{r}\text { SPENT } \\
\text { BLANKET } \\
\text { E3 CU FT } \\
0.00 \\
0.00 \\
0.00 \\
.55 \\
6.60 \\
154.00 \\
770.00 \\
1815.00 \\
3316.50 \\
4092.00\end{array}$ & $\begin{array}{l}0.00 \\
0.00 \\
0.00 \\
0.00 \\
0.00 \\
0.00 \\
0.00 \\
0.00 \\
0.00 \\
0.00\end{array}$ \\
\hline $\begin{array}{l}\text { YEAR } \\
1975 \\
1980 \\
1985 \\
1990 \\
2000 \\
2010 \\
2020 \\
2040 \\
2060 \\
2075\end{array}$ & $\begin{array}{c}\text { CO2 } \\
\text { E9 TONS } \\
5.67 \\
6.68 \\
8.16 \\
9.20 \\
10.12 \\
11.09 \\
8.92 \\
7.63 \\
5.49 \\
.5 .49\end{array}$ & $\begin{array}{c}\text { CO } \\
\text { E6 TONS } \\
8.32 \\
7.94 \\
8.47 \\
9.50 \\
10.53 \\
11.71 \\
10.34 \\
9.79 \\
9.24 \\
9.24\end{array}$ & $\begin{array}{c}\text { NOX } \\
\text { E6 TONS } \\
18.08 \\
21.39 \\
25.99 \\
29.25 \\
31.94 \\
35.05 \\
29.13 \\
25.22 \\
18.44 \\
18.44 .\end{array}$ & $\begin{array}{c}\text { S02 } \\
\text { E6 TONS } \\
14.12 \\
19.15 \\
27.16 \\
30.82 \\
35.22 \\
38.92 \\
29.25 \\
24.79 \\
19.72 \\
19.72\end{array}$ & $\begin{array}{c}\text { PART } \\
\text { E6 TONS } \\
8.36 \\
18.27 \\
30.75 \\
35.81 \\
44.36 \\
49.59 \\
32.26 \\
25.69 \\
21.34 \\
21.34\end{array}$ & $\begin{array}{r}H C \\
\text { E6 } T 0 \mathrm{~N} \\
2.73 \\
2.74 \\
2.96 \\
3.14 \\
3.18 \\
3.37 \\
2.67 \\
2.41 \\
2.13 \\
2.13\end{array}$ \\
\hline $\begin{array}{l}\text { YEAR } \\
1975 \\
1980 \\
1985 \\
1990 \\
2000 \\
2010 \\
2020 \\
2040 \\
2060\end{array}$ & $\begin{array}{c}\text { LAND USE } \\
\text { E6 ACRES } \\
14.17 \\
19.20 \\
25.56 \\
33.93 \\
41.15 \\
48.98 \\
53.38 \\
59.41 \\
74.41\end{array}$ & $\begin{array}{c}\text { DEA IHS } \\
\text { E.3 } \\
1.14 \\
2.16 \\
3.19 \\
3.94 \\
4.87 \\
5.56 \\
4.43 \\
3.58 \\
2.19 \\
2.19\end{array}$ & $\begin{array}{c}\text { INJURIES } \\
\text { E3 } \\
26.12 \\
46.80 \\
69.02 \\
88.30 \\
114.09 \\
133.48 \\
114.87 \\
97.91 \\
71.09 \\
71.21\end{array}$ & $\begin{array}{c}\text { MAN DAYS } \\
\text { LOSTE6 } \\
1.71 \\
3.13 \\
4.63 \\
5.84 \\
7.43 \\
8.61 \\
7.20 \\
6.03 \\
4.14 \\
4.13\end{array}$ & $\begin{array}{c}\text { SOLID WAST } \\
\text { E9 TONS } \\
.20 \\
.29 \\
.37 \\
.50 \\
.62 \\
.73 \\
.72 \\
.60 \\
.31\end{array}$ & \\
\hline
\end{tabular}

Figure D-15. Continued. 
HHO3 NO IMPORTS SOLAR ONLY

FOSSIL RESOURCES
TOTAL USE

$\begin{array}{cc}\text { YEAR } & \text { LIQ \& GAS } \\ 1975 & 52.80 \\ 1980 & 49.98 \\ 1985 & 49.45 \\ 1990 & 47.79 \\ 2000 & 39.79 \\ 2010 & 37.58 \\ 2020 & 26.11 \\ 2040 & 23.36 \\ 2060 & 20.29 \\ 2075 & 20.29\end{array}$

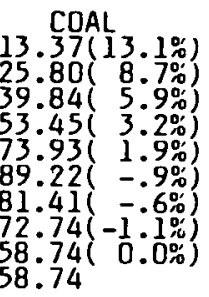

ELECIRIC GENERATION RESDURCE USE (THERMAL)

$\begin{array}{cccc}\text { LIO \& GAS } & \text { CUAL } & \text { FISSION } & \text { CTR } \\ 6.48 & 8.82 & 1.65 & 0.00 \\ 6.98 & 13.03 & 5.34 & 0.00 \\ 6.70 & 14.86 & 11.33 & 0.00 \\ 6.15 & 18.00 & 23.94 & 0.00 \\ 5.30 & 19.14 & 28.53 & 0.00 \\ 5.00 & 20.90 & 31.58 & .00 \\ 4.71 & 19.14 & 24.95 & 0.00 \\ 4.36 & 14.31 & 4.33 & 0.00 \\ 4.36 & 0.00 & 1.62 & 0.00 \\ 4.36 & 0.00 & .00 & .00\end{array}$

\section{ELECTRICAL GENERATION}

$\begin{array}{ll}\text { YEAR LIO } & \& \text { GAS } \\ 1975 & 2.43 \\ 1980 & 2.30 \\ 1985 & 2.20 \\ 1990 & 2.10 \\ 2000 & 1.80 \\ 2010 & 1.70 \\ 2020 & 1.60 \\ 2040 & 1.50 \\ 2060 & 1.50 \\ 2075 & 1.50\end{array}$
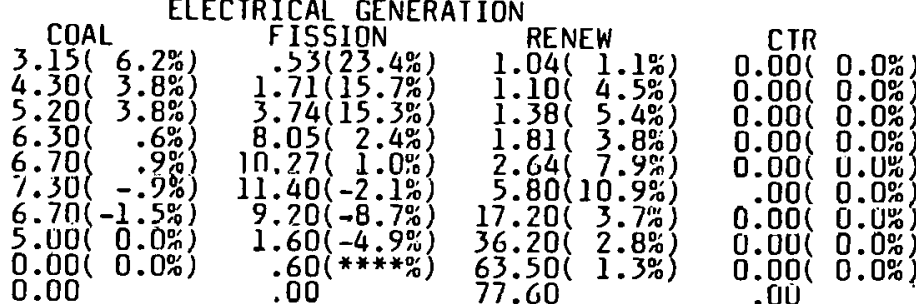

COAL TO SYNFUELS
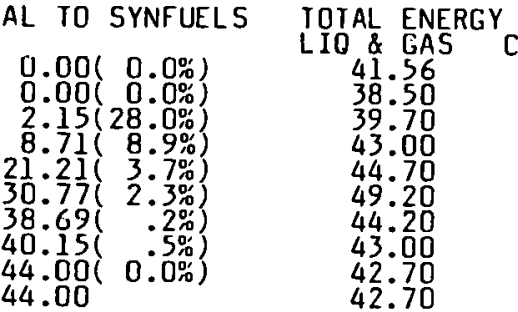

$$
\begin{aligned}
& 41.56 \\
& 38.50 \\
& 39.70 \\
& 43.00 \\
& 44.70 \\
& 49.20 \\
& 44.20 \\
& 43.00 \\
& 42.70
\end{aligned}
$$

\begin{tabular}{|c|c|c|c|c|c|}
\hline $\begin{array}{l}\text { YEAR } \\
1975 \\
1980 \\
1985 \\
1990 \\
2000 \\
2010 \\
2020 \\
2040 \\
2060 \\
2015\end{array}$ & $\begin{array}{l}R \& C \\
16.98 \\
14.89 \\
13.97 \\
15.20 \\
16.30 \\
18.51 \\
20.70 \\
23.98 \\
32.35 \\
37.69\end{array}$ & $\begin{array}{r}\text { IND } \\
16.73 \\
27.42 \\
41.84 \\
49.06 \\
58.97 \\
66.95 \\
55.38 \\
54.36 \\
61.22 \\
67.53\end{array}$ & $\begin{array}{l}\text { TRANS } \\
18.51 \\
16.66 \\
16.86 \\
18.94 \\
21.23 \\
23.79 \\
22.56 \\
22.88 \\
24.03\end{array}$ & $\begin{array}{r}\text { TOT USE } \\
52.22 \\
58.97 \\
72.67 \\
83.20 \\
96.50 \\
109.25 \\
98.64 \\
101.22 \\
111.60\end{array}$ & $\begin{array}{r}\text { TOT RES } \\
70.941 \\
84.26 \\
104.25 \\
130.35 \\
144.79 \\
174.95 \\
181.61 \\
203.86 \\
262.08\end{array}$ \\
\hline
\end{tabular}

CARRIER
COAL (IN
4.15
12.00
21.70
25.40
32.00
35.80
22.30
17.30
14.30
14.30

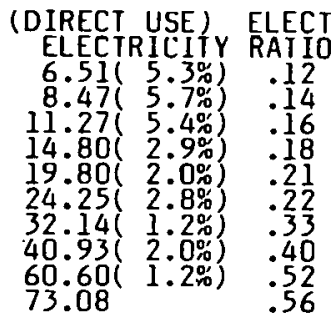

FINAL CONSUMPTION END USE

$\begin{array}{lrcc}\text { YEAK } & \text { R\& } \& & \text { LIO \& GNS } \\ 1975 & 13.20 & \text { IND } & \text { TRANS } \\ 1980 & 10.29 & 11.88 & 18.49 \\ 1985 & 8.27 & 14.72 & 16.59 \\ 1990 & 8.20 & 16.26 & 16.69 \\ 2000 & 7.50 & 16.97 & 20.54 \\ 2010 & 7.79 & 18.92 & 20.49 \\ 2020 & 6.79 & 16.94 & 20.67 \\ 2040 & 6.46 & 16.35 & 20.18 \\ 2060 & 6.42 & 16.24 & 20.04 \\ 2075 & 6.42 & 16.24 & 20.04\end{array}$

\begin{tabular}{rrr}
\multicolumn{3}{c}{ ELELIRICITY } \\
$\mathrm{R}_{2}$ EC & IND & TRANS \\
3.78 & 2.71 & .002 \\
4.60 & 3.80 & .07 \\
5.70 & 5.40 & .17 \\
7.00 & 7.40 & .40 \\
8.80 & 10.00 & 1.00 \\
10.72 & 12.23 & 1.30 \\
13.91 & 16.34 & 1.89 \\
17.52 & 20.71 & 2.70 \\
25.93 & 30.68 & 3.99 \\
31.27 & 36.99 & 4.82
\end{tabular}

TOTALS

$$
\begin{aligned}
& \begin{array}{l}
\text { CUM } \\
1975-2024 \\
\text { RESOURCE USE }
\end{array} \\
& \text { IOTAL COAL CAS 3194. } 3031 \text { TIOL } \\
& \text { Figure. D-16. Energy activity levels national } \\
& \text { annual totals (E15 Btu). }
\end{aligned}
$$


TOTAL ANNUAL SYSIEM COST (E9 DOLLARS)

$\begin{array}{lrrr} & & & \text { COST ASSUMPTIONS SEIS } \\ \text { YEAR } & \text { SEI1 } & \text { SET2 } & \text { SET3 } \\ 1975 & 148.1 & 148.1 & 148.1 \\ 1980 & 183.4 & 183.4 & 183.4 \\ 1985 & 239.5 & 239.5 & 239.5 \\ 1990 & 320.3 & 320.3 & 320.3 \\ 2000 & 431.9 & 431.9 & 431.9 \\ 2010 & 581.8 & 581.8 & 581.8 \\ 2020 & 730.6 & -730.6 & 730.6 \\ 2040 & 978.5 & 978.5 & 978.5 \\ 2060 & 1364.5 & 1364.5 & 1364.5 \\ 2075 & 1613.5 & 1613.5 & 1613.5\end{array}$

\begin{tabular}{ccrr} 
TO 1975 & \multicolumn{2}{l}{ DISCOUNTED PRESENT VALUE DF CUM } \\
$\begin{array}{c}0 \% \\
5 \%\end{array}$ & 82249.3 & 82249.3 & 82249.3 \\
$5 \%$ & 7845.4 & 7845.4 & 7845.3 \\
$10 \%$ & 2795.3 & 2795.3 & 2795.3 \\
$15 \%$ & 1632.9 & 1632.9 & 1632.9
\end{tabular}

$\begin{array}{crrr}\text { TO } 1995 & & & \\ 0 \% & 77331.5 & 77331.5 & 77331.5 \\ 5 \% & 12958.5 & 12958.5 & 12958.5 \\ 10 \% & 5587.6 & 5587.5 & 5587.5 \\ 15 \% & 3544.5 & 3544.5 & 3544.5\end{array}$

$\begin{array}{crrr}\text { T0 } 2010 & 70392.7 & 70392.7 & 70392.7 \\ 0 \% & 16719.6 & 16719.6 & 16719.6 \\ 5 \% & 7933.4 & 7933.4 & 7933.4 \\ 10 \% & 5200.0 & 5200.0 & 5200.0 \\ 15 \% & & \end{array}$

$\begin{array}{crrr}\text { To } 2020 & & & \\ 0 \% & 63876.7 & 63876.7 & 63876.7 \\ 5 \% & 18709.3 & 18709.3 & 18709.3 \\ 10 \% & 9360.3 & 9360.3 & 9360.3 \\ 15 \% & 6219.5 & 6219.5 & 6219.5\end{array}$

HEALTH \& ENVIRON - EMISSIONS \& EFFECTS

\begin{tabular}{|c|c|c|c|c|c|c|}
\hline $\begin{array}{l}\text { YEAR } \\
1975 \\
1980 \\
1985 \\
1990 \\
2000 \\
2010 \\
2020 \\
2040 \\
2060 \\
2075\end{array}$ & $\begin{array}{l}\text { POP EXP } \\
\text { E3 } \\
\text { MAN REM } \\
14.31 \\
46.17 \\
100.98 \\
217.35 \\
277.29 \\
307.83 \\
248.40 \\
43.20 \\
16.20\end{array}$ & $\begin{array}{c}\text { KR-85 } \\
\text { E6 } \\
\text { CURIES } \\
13.04 \\
42.07 \\
92.00 \\
198.03 \\
252.64 \\
280.44 \\
226.32 \\
39.36 \\
14.76\end{array}$ & $\begin{array}{r}\text { TRIT } \\
\text { E5 } \\
\text { CURIES } \\
4.66 \\
15.05 \\
32.91 \\
70.84 \\
90.38 \\
100.32 \\
80.96 \\
14.08 \\
5.28\end{array}$ & $\begin{array}{c}\text { RAD WASTE } \\
\text { E3 } \\
\text { CUF! } \\
2.92 \\
9.41 \\
20.57 \\
44.28 \\
56.49 \\
62.70 \\
50.60 \\
8.80 \\
3.30 \\
.00\end{array}$ & $\begin{array}{c}\text { SPENT } \\
\text { BLANKET } \\
\text { E3 CU FT } \\
0.00 \\
0.00 \\
0.00 \\
0.00 \\
0.00 \\
0.05 \\
0.00 \\
0.00 \\
0.00\end{array}$ & ( SPARE \\
\hline
\end{tabular}

\begin{tabular}{|c|c|c|c|c|c|c|}
\hline $\begin{array}{l}\text { AR } \\
75 \\
80 \\
85 \\
90 \\
00 \\
10 \\
20 \\
40 \\
60 \\
60\end{array}$ & $\begin{array}{c}\text { CO2 } \\
\text { E9 TONS } \\
5.67 \\
6.68 \\
8.16 \\
9.20 \\
10.12 \\
11.09 \\
8.92 \\
7.63 \\
5.49 \\
5.49\end{array}$ & $\begin{array}{c}\text { CO } \\
\text { E6 IONS } \\
8.32 \\
7.94 \\
8.47 \\
9.50 \\
10.53 \\
11.72 \\
10.34 \\
9.79 \\
9.24 \\
9.24\end{array}$ & $\begin{array}{c}\text { NOX } \\
\text { E6 TONS } \\
18.08 \\
21.39 \\
25.99 \\
29.25 \\
31.94 \\
35.05 \\
29.13 \\
25.22 \\
18.44 \\
18.44\end{array}$ & $\begin{array}{c}\text { SO2 } \\
\text { E6 TONS } \\
14.12 \\
19.75 \\
27.16 \\
30.82 \\
35.22 \\
38.92 \\
29.25 \\
24.79 \\
19.72 \\
19.72\end{array}$ & $\begin{array}{c}\text { PART } \\
\text { E6 TONS } \\
8.36 \\
18.27 \\
30.75 \\
35.81 \\
44.36 \\
49.59 \\
32.26 \\
25.69 \\
21.34 \\
21.34\end{array}$ & $\begin{aligned} \text { HC } \\
\text { E6 } 10 \mathrm{NS} \\
2.73 \\
2.74 \\
2.96 \\
3.14 \\
3.18 \\
3.37 \\
2.67 \\
2.41 \\
2.13 \\
2.13\end{aligned}$ \\
\hline $\begin{array}{l}80 \\
85 \\
90 \\
00 \\
10\end{array}$ & $\begin{array}{l}\text { LAND USE } \\
\text { E6 ACRES } \\
14.17 \\
19.20 \\
25.56 \\
33.93 \\
41.17 \\
49.49 \\
55.90 \\
65.35 \\
85.26 \\
99.81\end{array}$ & $\begin{array}{c}\text { DEATHS } \\
\text { E3 } \\
1.14 \\
2.16 \\
3.19 \\
3.94 \\
4.87 \\
5.56 \\
4.43 \\
3.58 \\
2.18 \\
2.18\end{array}$ & $\begin{array}{c}\text { INJURIES } \\
\text { E3 } \\
26.12 \\
46.80 \\
69.02 \\
88.30 \\
114.09 \\
133.43 \\
114.64 \\
97.35 \\
70.06 \\
69.94\end{array}$ & $\begin{array}{c}\text { MAN DAYS } \\
\text { LOST E6 } \\
1.71 \\
3.13 \\
4.63 \\
5.84 \\
7.43 \\
8.61 \\
7.20 \\
6.01 \\
4.11 \\
4.11\end{array}$ & $\begin{array}{c}\text { SOL ID WASTE } \\
\text { E9 TONS } \\
.20 \\
.29 \\
.37 \\
.50 \\
.62 \\
.73 \\
.72 \\
.60 \\
.31\end{array}$ & \\
\hline
\end{tabular}

Figure D-16. Continued. 
HHO4 NO IMPORTS, FISSION ONLY (FBR)

FOSSIL RESOURCES

TOTAL USE

$\begin{array}{lr}\text { YEAR } & \text { LIQ } \\ 1975 & 52.80 \\ 1980 & 49.98 \\ 1985 & 49.45 \\ 1990 & 47.79 \\ 2000 & 39.79 \\ 2010 & 37.58 \\ 2020 & 26.11 \\ 2040 & 23.36 \\ 2060 & 20.29 \\ 2075 & 20.29\end{array}$

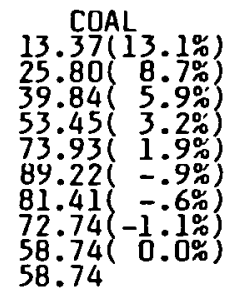

ELECTRIC GENERATION

RESOURCE USE (THERMAL)

\section{ELECTRICAL GENERATION}

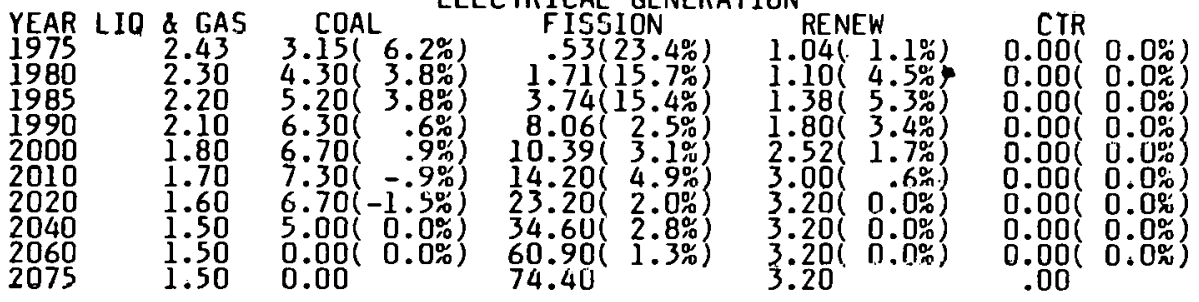

COAL TO SYNFUELS TOTAL ENERGY CARRIERS (DIRECT USE) ELECT

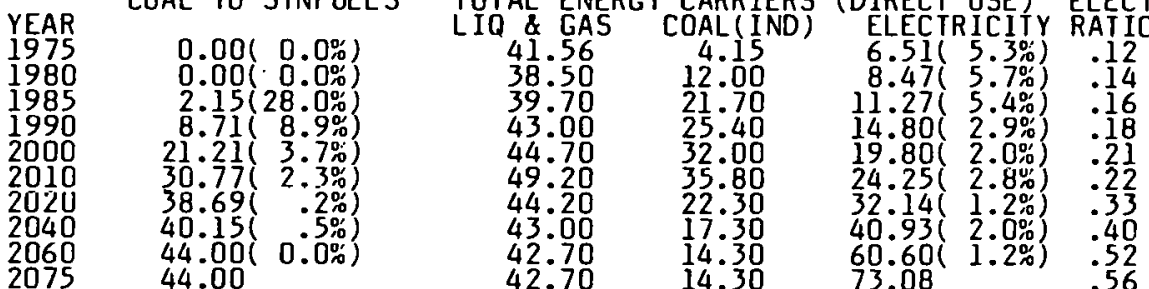

FINAL CONSUMPTION END USE

$\begin{array}{ccc}\text { YEAR } & \text { R \& C } & \text { LIQ \& LAS } \\ \text { IND } \\ 1975 & 13.20 & 9.88 \\ 1980 & 10.29 & 11.62 \\ 1905 & 8.27 & 14.14 \\ 1990 & 8.20 & 16.26 \\ 2 \text { UUU } & 7.50 & 16.9 .7 \\ 2010 & 7.79 & 18.92 \\ 2020 & 6.79 & 16.74 \\ 2010 & 6.46 & 16.35 \\ 2060 & 6.42 & 16.24 \\ 2075 & 6.42 & 16.24\end{array}$

TRANS
18.49
12.59
16.69
18.54
20.23
22.49
20.67
20.18
20.04
20.04

$\begin{array}{rrr} & \text { ELECIRICITY } \\ R \quad C^{2} & \text { IND } & \text { TRANS } \\ 3.78 & 2.71 & .02 \\ 1.60 & 3.00 & .07 \\ 5.70 & 5.40 & .17 \\ 7.00 & 7.40 & .40 \\ 8.80 & 11.00 & 1.00 \\ 10.72 & 12.23 & 1.30 \\ 13.91 & 16.34 & 1.89 \\ 17.52 & 20.71 & 2.70 \\ 25.93 & 30.68 & 3.99 \\ 31.27 & 36.99 & 4.82\end{array}$

TOTALS

$\begin{array}{llllll}\text { YFAR } & \text { R } \$ C & \text { IND } & \text { TRANS } & \text { IUI USE } & \text { TOT RESOURCE } \\ 1975 & 16.98 & 16.73 & 18.51 & 52.22 & 70.94(3.4 \%) \\ 1980 & 14.89 & 27.42 & 16.66 & 58.97 & 84.26(4.3 \%) \\ 1985 & 13.97 & 41.84 & 16.86 & 72.67 & 104.25(4.5 \%) \\ 1990 & 15.20 & 49.06 & 18.94 & 83.20 & 130.35(1.4 \%) \\ 2000 & 16.30 & 58.97 & 21.23 & 96.50 & 149.78(1.5 \%) \\ 2010 & 18.51 & 66.95 & 23.79 & 109.25 & 174.74(1.3 \%) \\ 2020 & 20.70 & 55.38 & 22.56 & 98.64 & 179.58(.5 \%) \\ 2040 & 23.98 & 51.36 & 22.86 & 101.22 & 196.88(1.2 \%) \\ 2060 & 32.35 & 61.23 & 24.03 & 117.60 & 252.60(-.4 \%) \\ 2075 & 37.69 & 67.53 & 24.86 & 130.08 & 236.97\end{array}$

\begin{tabular}{cccc} 
& \multicolumn{2}{c}{ CUM R RESOURCE USE } \\
& $1975-2024$ & $1995-2044$ & $1975-2075$ \\
IOIAL COAL \& LAS & 3194. & 3917. & 6571. \\
TOTAL LIÖ \& LAS & 2031. & 1503. & 3134.
\end{tabular}

Figure D-17. Energy actiyity leyels national annual totals (E15 Btu). 
TOTAL ANNUAL SYSIEM COST (E9 DOLLARS)

\begin{tabular}{|c|c|c|c|}
\hline $\begin{array}{l}\text { YEAR } \\
1975 \\
1980 \\
1985 \\
1990 \\
2000 \\
2010 \\
2020 \\
2040 \\
2060 \\
2075\end{array}$ & $\begin{array}{l}\text { SETI } \\
148.1 \\
183.4 \\
239.5 \\
320.3 \\
431.6 \\
562.7 \\
637.1 \\
758.1 \\
961.7 \\
1116.6\end{array}$ & $\begin{array}{l}\text { SET2 COST A } \\
148.1 \\
183.4 \\
239.5 \\
320.3 \\
431.6 \\
562.7 \\
637.1 \\
758.1 \\
961.7 \\
1116.6\end{array}$ & $\begin{array}{l}\text { ASSUMPT IO } \\
\text { SET } 3 \\
148.1 \\
183.4 \\
239.5 \\
320.3 \\
431.6 \\
562.7 \\
637.1 \\
758.1 \\
961.7 \\
1116.6\end{array}$ \\
\hline 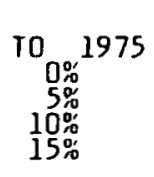 & $\begin{array}{l}\text { DISCOUNTED } \\
65250.5 \\
7316.7 \\
2758.7 \\
1628.7\end{array}$ & $\begin{array}{l}\text { PRESENT VALUE } \\
65250.5 \\
7316.7 \\
2758.7 \\
1628.7\end{array}$ & $\begin{array}{l}\text { OF CUM. } \\
65250.5 \\
7316.7 \\
2758.7 \\
1628.7\end{array}$ \\
\hline $\begin{array}{c}10_{0} 1995^{\circ} \\
0 \% \\
5 \% \\
10 \% \\
15 \% \\
15 \%\end{array}$ & $\begin{array}{r}60332.6 \\
11555.7 \\
5341.2 \\
3474.6\end{array}$ & $\begin{array}{r}60332.6 \\
11555.7 \\
5341.2 \\
3474.6\end{array}$ & $\begin{array}{r}60332.6 \\
11555.7 \\
5341.2 \\
3474.6\end{array}$ \\
\hline $\begin{array}{c}\text { T0 2010 } \\
0 \% \\
5 \% \\
10 \% \\
15 \%\end{array}$ & $\begin{array}{r}53434.4 \\
13850.2 \\
6959.2 \\
4695.5\end{array}$ & $\begin{array}{r}53434.4 \\
13850.2 \\
6959.2 \\
4695.5\end{array}$ & $\begin{array}{r}53434.4 \\
13850.2 \\
6959.2 \\
4695.5\end{array}$ \\
\hline 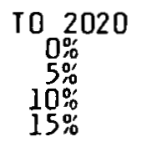 & $\begin{array}{r}47424.4 \\
14663.7 \\
7618.7 \\
5164.8\end{array}$ & $\begin{array}{r}47424.4 \\
14663.7 \\
7618.7 \\
5164.8\end{array}$ & $\begin{array}{r}47424.4 \\
14663.7 \\
7618.7 \\
5164.8\end{array}$ \\
\hline
\end{tabular}

HEALTH \& ENVIRON - EMISSIONS \& EFFECTS

\begin{tabular}{|c|c|c|c|c|c|c|}
\hline $\begin{array}{l}\text { YEAR } \\
1975 \\
1980 \\
1985 \\
1990 \\
2000 \\
2010 \\
2020 \\
2040 \\
2060 \\
2075\end{array}$ & $\begin{array}{l}\text { POP EXP } \\
\text { E3 } \\
\text { MAN REM } \\
14.31 \\
46.17 \\
100.98 \\
217.62 \\
280.53 \\
383.40 \\
626.40 \\
934.20 \\
1644.30 \\
2008.80\end{array}$ & $\begin{array}{r}\text { KR-85 } \\
\text { E6 } \\
\text { CURIES } \\
13.04 \\
42.07 \\
92.00 \\
198.28 \\
255.59 \\
349.32 \\
570.72 \\
851.16 \\
1498.14 \\
1830.22\end{array}$ & $\begin{array}{r}\text { TRIT } \\
\text { ES } \\
\text { CURIES } \\
4.66 \\
15.05 \\
32.91 \\
70.93 \\
91.43 \\
124.96 \\
204.16 \\
304.48 \\
535.92 \\
654.71\end{array}$ & $\begin{array}{c}\text { RAD WASTE } \\
\text { E3 } \\
\text { CU FT } \\
2.92 \\
9.41 \\
20.57 \\
44.33 \\
57.15 \\
78.10 \\
127.60 \\
190.30 \\
334.95 \\
409.19\end{array}$ & $\begin{array}{c}\text { SPENT } \\
\text { BLANKET } \\
\text { E CU FT } \\
0.00 \\
0.00 \\
0.00 \\
0.00 \\
0.00 \\
0.00 \\
0.00 \\
0.00 \\
0.00 \\
.05\end{array}$ & $\begin{array}{l}0.00 \\
0.00 \\
0.00 \\
0.00 \\
0.00 \\
0.00 \\
0.00 \\
0.00 \\
0.00 \\
0.00\end{array}$ \\
\hline $\begin{array}{l}\text { YEAR } \\
1975 \\
1980 \\
1985 \\
1990 \\
2000 \\
2010 \\
2020 \\
2040 \\
2060 \\
2075\end{array}$ & $\begin{array}{c}\text { CO2 } \\
\text { E9 TONS } \\
5.67 \\
6.68 \\
8.16 \\
9.20 \\
10.12 \\
11.09 \\
8.92 \\
7.63 \\
5.49 \\
5.49\end{array}$ & $\begin{array}{c}\text { CO } \\
\text { E6 TONS } \\
8.32 \\
7.94 \\
8.47 \\
9.50 \\
10.53 \\
11.72 \\
10.34 \\
9.79 \\
9.24 \\
9.24\end{array}$ & $\begin{array}{c}\text { NOX } \\
\text { E6 TONS } \\
18.7 R \\
21.39 \\
25.99 \\
29.25 \\
31.94 \\
35.05 \\
29.15 \\
25.26 \\
18.52 \\
18.54\end{array}$ & $\begin{array}{c}\text { SO2 } \\
\text { E6 TONS } \\
14.1 ? \\
19.75 \\
27.16 \\
30.82 \\
35.22 \\
38.92 \\
29.25 \\
24.79 \\
19.72 \\
19.72\end{array}$ & $\begin{array}{c}\text { PART } \\
\text { E6 TONS } \\
\text { B. } 36 \\
18.27 \\
30.75 \\
35.81 \\
44.36 \\
49.59 \\
32.27 \\
25.71 \\
21.38 \\
21.39\end{array}$ & $\begin{array}{c}\text { HC } \\
\text { E6 TONS } \\
2.73 \\
2.74 \\
2.96 \\
3.14 \\
3.18 \\
3.37 \\
2.67 \\
2.41 \\
2.14 \\
2.14\end{array}$ \\
\hline $\begin{array}{l}\text { YEAR } \\
1975 \\
1980 \\
1905 \\
1990 \\
2000 \\
2010 \\
2020 \\
2040 \\
2060\end{array}$ & $\begin{array}{c}\text { LAND USE } \\
\text { E6. ACRES } \\
14.17 \\
19.20 \\
25.56 \\
33.93 \\
41.15 \\
48.98 \\
53.38 \\
59.41 \\
74.41 \\
86.42\end{array}$ & $\begin{array}{l}2.16 \\
3.19 \\
3.94 \\
4.87 \\
5.57 \\
4.51 \\
3.79 \\
2.57 \\
2.65\end{array}$ & $\begin{array}{c}\text { INJURIES } \\
\text { E3 } \\
26.12 \\
46.80 \\
69.02 \\
88.31 \\
114.12 \\
133.99 \\
117.44 \\
103.95 \\
82.12 \\
84.82\end{array}$ & $\begin{array}{c}\text { MAN DAYS } \\
\text { LOST E6 } \\
1.71 \\
3.13 \\
4.63 \\
5.84 \\
7.43 \\
8.64 \\
7.35 \\
6.38 \\
4.79 \\
4.94\end{array}$ & $\begin{array}{c}\text { SOLID WASTE } \\
\text { EY IONS } \\
.20 \\
.29 \\
.37 \\
.50 \\
.62 \\
.74 \\
.77 \\
.71 \\
.51 \\
.56\end{array}$ & \\
\hline
\end{tabular}

Fj,gure D-17. Continued. 
LOW-ZEG BASE CASE

FOSSIL RESOURCES

$\begin{array}{lc}\text { YEAR } & \text { LIQ } \& \text { GAS } \\ 1975 & 52.80 \\ 1980 & 55.14 \\ 1985 & 59.85 \\ 1990 & 56.78 \\ 2000 & 48.14 \\ 2010 & 41.71 \\ 2020 & 40.77 \\ 2040 & 40.35 \\ 2060 & 40.37 \\ 2075 & 40.37\end{array}$

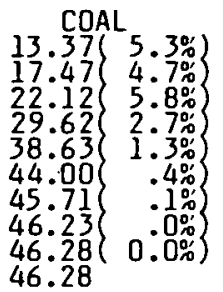

ELECTRIC GENERATION RESOURCE USE (THERMAL)

$\begin{array}{cccc}\text { LIQ \& CAS } & \text { COAL } & \text { FISSION } & \text { CTR } \\ 6.48 & 8.82 & 1.65 & 0.00 \\ 6.56 & 12.25 & 5.02 & 0.00 \\ 6.03 & 13.37 & 10.20 & 0.00 \\ 5.23 & 13.56 & 20.37 & 0.00 \\ 3.92 & 14.16 & 21.36 & 0.00 \\ 3.30 & 14.37 & 22.72 & 0.00 \\ 3.04 & 14.41 & 23.13 & 0.00 \\ 2.79 & 14.64 & 23.53 & 0.00 \\ 2.79 & 14.65 & 23.54 & 0.00 \\ 2.79 & 14.65 & 23.54 & 0.00\end{array}$

\section{ELECTRICAL, GENERATION}

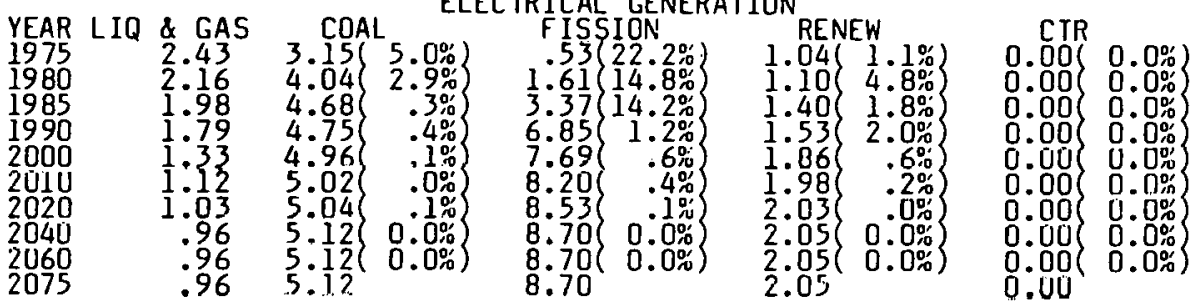

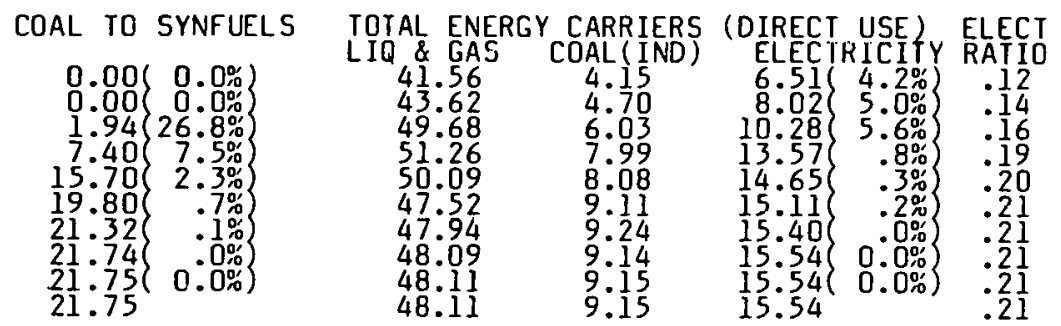

FINAL CONSUMPTION END USE

$\begin{array}{llcl}\text { YEAR } & R \& C & \text { LIQ \& } \mathrm{H} \text { GAS } \\ 1975 & 13.20 & \text { IND } & \text { TRANS } \\ 1980 & 11.66 & 13.88 & 18.49 \\ 1985 & 10.35 & 18.45 & 18.80 \\ 1990 & 9.78 & 19.38 & 20.88 \\ 1990 & 8.41 & 19.01 & 22.10 \\ 2000 & 82.67 \\ 2010 & 7.52 & 18.28 & 21.71 \\ 2020 & 7.37 & 18.16 & 22.42 \\ 2040 & 7.23 & 18.29 & 22.57 \\ 2060 & 7.23 & 18.30 & 22.58 \\ 2075 & 7.23 & 18.30 & 22.58\end{array}$

$\begin{array}{lcr} & \text { ELEETRICITY } & \\ R \& C & \text { IND } & \text { TRANS } \\ 3.78 & 2.71 & .02 \\ 4.36 & 3.60 & .07 \\ 5.20 & 4.93 & .15 \\ 6.47 & 6.79 & .37 \\ 6.51 & 7.40 & .74 \\ 6.68 & 7.62 & .81 \\ 6.67 & 7.83 & .91 \\ 6.65 & 7.87 & 1.02 \\ 6.65 & 7.87 & 1.02 \\ 6.65 & 7.87 & 1.02\end{array}$

TOTALS

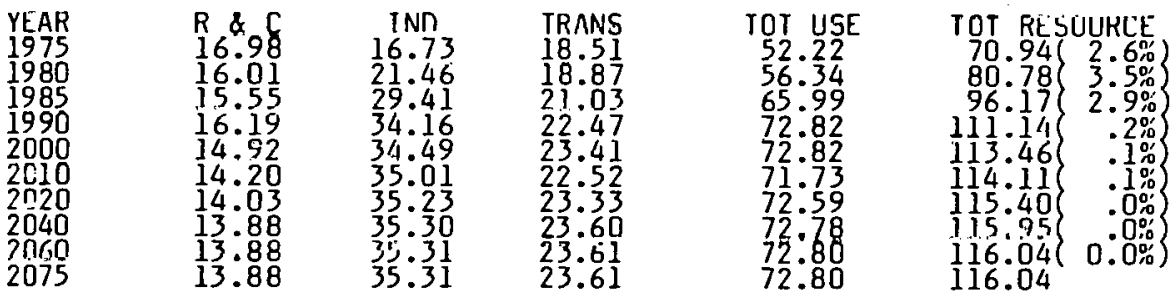

\section{CUM. RESOURCE USE
$1975-2024$
$1995-2044$
$1975-2075$ \\ FOIALE CPAL \& GAS 2435: 3128:}

Figure D-18. Energy activity levels national annual totals (El5 Btu). 
TOIAL ANNUAL SYSTEM COST (ES DCLLAFS)

\begin{tabular}{|c|c|c|c|}
\hline $\begin{array}{l}\text { YEAR } \\
1975 \\
1980 \\
1985 \\
1990 \\
2000 \\
2010 \\
2020 \\
2040 \\
2060 \\
2075\end{array}$ & $\begin{array}{l}\text { SETI } \\
148.1 \\
180.4 \\
229.8 \\
284.6 \\
338.2 \\
378.8 \\
413.4 \\
469.3 \\
523.0 \\
563.1\end{array}$ & $\begin{array}{l}\text { SEI2 COST A } \\
148.1 \\
180.4 \\
229.8 \\
284.6 \\
338.2 \\
378.8 \\
413.4 \\
469.3 \\
523.0 \\
563.1\end{array}$ & $\begin{array}{c}\text { ASSUMPI IO } \\
\text { SE I3 } \\
148.1 \\
180.4 \\
229.8 \\
284.6 \\
338.2 \\
378.8 \\
413.4 \\
469.3 \\
523.0 \\
563.1\end{array}$ \\
\hline $\begin{array}{c}10 \\
0 \% \\
0 \% \\
5 \% \\
10 \% \\
15 \%\end{array}$ & $\begin{array}{l}\text { DISCOUNTED } \\
41099.1 \\
5774.8 \\
2456.8 \\
1527.2\end{array}$ & $\begin{array}{l}\text { PRESENT VALUE } \\
\begin{array}{l}41099.1 \\
5774.8 \\
2456.8 \\
1527.2\end{array}\end{array}$ & $\begin{array}{l}\text { OF CUM. } \\
41099.1 \\
5774.8 \\
2456.8 \\
1527.2\end{array}$ \\
\hline $\begin{array}{c}10,1995 \\
0 \% \\
5 \% \\
10 \% \\
15 \%\end{array}$ & $\begin{array}{r}36539.0 \\
7926.5 \\
3920.5 \\
2642.5\end{array}$ & $\begin{array}{r}36539.0 \\
7926.5 \\
3920.5 \\
2642.5\end{array}$ & $\begin{array}{r}36539.0 \\
7926.5 \\
3920.5 \\
2642.5\end{array}$ \\
\hline $\begin{array}{c}\text { TO } 2010 \\
0 \% \\
5 \% \\
10 \% \\
15 \% \\
15 \%\end{array}$ & $\begin{array}{r}31346.7 \\
8714.6 \\
4510.9 \\
3074.7\end{array}$ & $\begin{array}{r}31346.7 \\
8714.6 \\
4510.9 \\
3074.7\end{array}$ & $\begin{array}{r}31346.7 \\
8714.6 \\
4510.9 \\
3074.7\end{array}$ \\
\hline $\begin{array}{c}\text { T0 } 2020 \\
0 \% \\
5 \% \\
10 \% \\
15 \%\end{array}$ & $\begin{array}{r}27400.8 \\
9002.4 \\
4829.9 \\
3316.2\end{array}$ & $\begin{array}{r}27400.8 \\
9002.4 \\
4829.9 \\
3316.2\end{array}$ & $\begin{array}{r}27400.8 \\
9002.4 \\
4829.9 \\
3316.2\end{array}$ \\
\hline
\end{tabular}

HEALTH \& ENVIRON - EMISSIONS \& EFFECTS

\begin{tabular}{|c|c|c|c|c|c|c|}
\hline $\begin{array}{l}\text { YEAR } \\
1975 \\
1980 \\
1985 \\
1990 \\
2000 \\
2010 \\
2020 \\
2040 \\
2060 \\
2075\end{array}$ & $\begin{array}{l}\text { POP EXP } \\
\text { E3 } \\
\text { MAN REM } \\
14.31 \\
43.47 \\
90.99 \\
184.95 \\
207.63 \\
221.40 \\
230.31 \\
234.90 \\
234.90 \\
234.90\end{array}$ & $\begin{array}{l}\text { KR-85 } \\
\text { E6 } \\
\text { CURIES } \\
13.04 \\
39.61 \\
82.90 \\
168.51 \\
189.17 \\
201.72 \\
209.84 \\
214.02 \\
214.02 \\
214.02\end{array}$ & $\begin{array}{r}\text { TRIT } \\
\text { E5 } \\
\text { CURIES } \\
4.66 \\
14.17 \\
29.66 \\
60.28 \\
67.67 \\
72.16 \\
75.06 \\
76.56 \\
76.56 \\
76.56\end{array}$ & $\begin{array}{c}\text { RAD WASTE } \\
\text { E3 } \\
\text { CU FT } \\
2.92 \\
8.86 \\
18.54 \\
37.68 \\
42.30 \\
45.10 \\
46.92 \\
47.85 \\
47.85 \\
47.85\end{array}$ & $\begin{array}{r}\text { SPENT } \\
\text { BLANKE } \\
\text { E3 CU FI } \\
0.00 \\
0.00 \\
0.000 \\
0.00 \\
0.00 \\
0.00 \\
0.00 \\
0.00 \\
0.00 \\
0.00\end{array}$ & $\begin{array}{l}0.00 \\
0.00 \\
0.00 \\
0.00 \\
0.00 \\
0.00 \\
0.00 \\
0.00 \\
0.00 \\
0.00\end{array}$ \\
\hline $\begin{array}{l}\text { YEAR } \\
1975 \\
1980 \\
1985 \\
1990 \\
2000 \\
2010 \\
2020 \\
2040 \\
2060 \\
2075\end{array}$ & $\begin{array}{c}\text { CO2 } \\
\text { E9 TONS } \\
5.67 \\
6.14 \\
6.96 \\
7.27 \\
7.11 \\
6.97 \\
7.00 \\
7.00 \\
7.01 \\
7.01\end{array}$ & $\begin{array}{c}\text { CO } \\
\text { E6 TONS } \\
0.32 \\
8.56 \\
9.56 \\
10.16 \\
10.40 \\
10.04 \\
10.34 \\
10.40 \\
10.40 \\
10.40\end{array}$ & $\begin{array}{c}\text { NOX } \\
\text { E6 TONS } \\
18.08 \\
19.92 \\
22.87 \\
23.78 \\
23.22 \\
22.78 \\
22.76 \\
22.76 \\
22.77 \\
22.77\end{array}$ & $\begin{array}{c}\text { SO2 } \\
\text { E6 TONS } \\
14.12 \\
15.90 \\
19.04 \\
20.50 \\
19.97 \\
20.00 \\
19.97 \\
19.92 \\
19.93 \\
19.93\end{array}$ & $\begin{array}{c}\text { PART } \\
\text { E6 TONS } \\
8.36 \\
9.36 \\
11.61 \\
14.23 \\
14.34 \\
15.50 \\
15.69 \\
15.59 \\
15.60 \\
15.60\end{array}$ & $\begin{array}{c}\mathrm{HC} \\
\text { E6 }{ }^{\mathrm{T}} \mathrm{N} S \mathrm{NS} \\
2.73 \\
2.83 \\
3.12 \\
3.15 \\
2.94 \\
2.74 \\
2.75 \\
2.75 \\
2.75 \\
2.75\end{array}$ \\
\hline $\begin{array}{l}\text { YEAR } \\
1975 \\
1980 \\
1985 \\
1990 \\
2000 \\
2010 \\
2020 \\
2040 \\
2060\end{array}$ & $\begin{array}{l}\text { LAND USF } \\
\text { E6 ACRES } \\
14.17 \\
17.00 \\
20.82 \\
25.48 \\
27.75 \\
28.95 \\
29.56 \\
29.83 \\
29.84 \\
29.84\end{array}$ & $\begin{array}{c}\text { NFAIHS } \\
\text { E3 } \\
1.14 \\
1.48 \\
1.76 \\
2.07 \\
2.31 \\
2.50 \\
2.55 \\
2.57 \\
2.57 \\
2.57\end{array}$ & $\begin{array}{c}\text { IN.JIIRIES } \\
\text { E3 } \\
26.12 \\
33.37 \\
40.54 \\
49.94 \\
59.24 \\
65.22 \\
67.08 \\
67.70 \\
67.77 \\
67.77\end{array}$ & $\begin{array}{c}\text { MAN DAYS } \\
\text { COSfEG } \\
1.71 \\
2.20 \\
2.65 \\
3.20 \\
3.72 \\
4.08 \\
4.18 \\
4.22 \\
4.22 \\
4.22\end{array}$ & $\begin{array}{c}\text { SOLID WASTE } \\
\text { EY YUNS } \\
.20 \\
.26 \\
.32 \\
.38 \\
.45 \\
.48 \\
.49 \\
.50 \\
.50 \\
.50\end{array}$ & \\
\hline
\end{tabular}

Figure D-18. Continuad. 
LZO2 FUSION REPLACES FBR FOSSIL RESOURCES

ELECTRIC GENERATION TOTAL USE

RESOURCE USE (THERMAL)

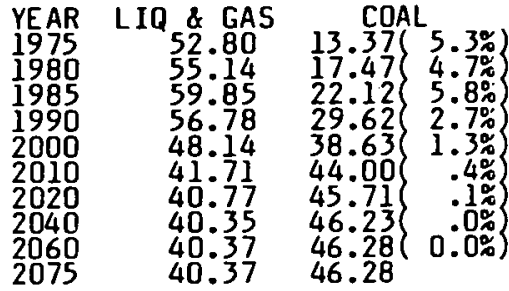

\begin{tabular}{cccr} 
LIQ \& GAS & COAL & FISSION & \multicolumn{1}{c}{ CTR } \\
6.48 & 8.82 & 1.65 & 0.00 \\
6.56 & 12.25 & 5.02 & 0.00 \\
6.03 & 13.37 & 10.20 & 0.00 \\
5.23 & 13.56 & 20.34 & .03 \\
3.92 & 14.16 & 21.03 & .34 \\
3.30 & 14.37 & 15.79 & 7.14 \\
3.04 & 14.41 & 12.28 & 11.43 \\
2.79 & 14.64 & 1.89 & 22.86 \\
2.79 & 14.65 & .81 & 24.00 \\
2.79 & 14.65 & .00 & 24.86
\end{tabular}

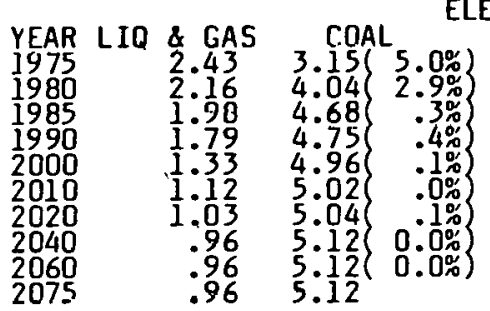

ELECTRICAL GENERATION

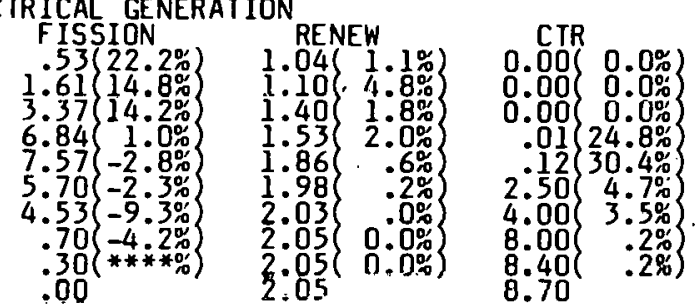

COAL TO SYNFUELS

$\begin{array}{ccccc}\text { TOTAL ENERGY CARRIERS } & \text { (DIRECT USE) } & \text { ELECT } \\ \text { LIO } 8 \text { GAS } & \text { COAL (IND) } & \text { ELECIRICIIY } & \text { RAIID } \\ 41.56 & 4.15 & 6.51 & 4.2 \% & .12 \\ 43.62 & 4.70 & 8.02 & 5.0 \% & .14 \\ 49.68 & 6.03 & 10.28 & 5.6 \% & .16 \\ 51.26 & 7.99 & 13.57 & .8 \% & .19 \\ 50.09 & 9.08 & 14.65 & .3 \% & .20 \\ 47.52 & 9.11 & 15.11 & .2 \% & .21 \\ 47.94 & 9.24 & 15.40 & .0 \% & .21 \\ 48.09 & 9.14 & 15.54 & 0.0 \% & : 21 \\ 48.11 & 9.15 & 15.54 & 0.0 \% & .21 \\ 48.11 & 9.15 & 15.54 & & .21\end{array}$

FINAL CONSUMMTION END USE

\begin{tabular}{|c|c|c|}
\hline $\begin{array}{l}\text { YEAR } \\
1975 \\
1980 \\
1905 \\
1990 \\
2000 \\
2010 \\
2020 \\
2040 \\
2060 \\
2075\end{array}$ & $\begin{array}{r}R \& C \\
13.20 \\
11.66 \\
10.35 \\
9.78 \\
8.41 \\
7.52 \\
7.37 \\
7.23 \\
7.23 \\
7.23\end{array}$ & $\begin{array}{c}\text { IQ \& GAS } \\
1 \text { ND } \\
9.88 \\
13.16 \\
18.45 \\
19.34 \\
19.01 \\
18.28 \\
18.16 \\
18.29 \\
18.30 \\
18.30\end{array}$ \\
\hline
\end{tabular}

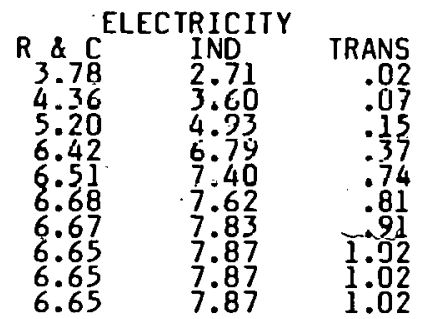

IUIALS

YFAR
1975
1980
1985
1990
2000
2010
2020
2040
2060
2075

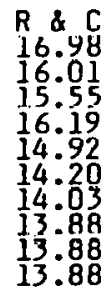

$\begin{array}{ll}\text { IND } & \text { TRANS } \\ 16.73 & 18.51 \\ 21.46 & 18.87 \\ 29.41 & 21.03 \\ 34.16 & 22.47 \\ 34.49 & 23.41 \\ 35.01 & 22.52 \\ 35.23 & 23.33 \\ 35.30 & 23.67 \\ 35.31 & 23.61 \\ 35.31 & 23.61\end{array}$
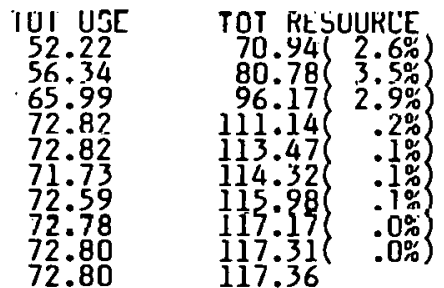

\begin{tabular}{cccc} 
& \multicolumn{2}{c}{ CUM. RESOURCE USE } & \\
& $1975-2024$ & $1995-2044$ & $1975-2075$ \\
TOTAL COAL & 1731. & 2198. & 4089. \\
TOTAL LIU \& GAS & 2439. & 2126. & 4500.
\end{tabular}

Figure D-19. Energy activity levels national annual totals (E15 Btú). 
TOTAL ANNUAL SYSTEM COST (E9 DOLLARS)

\begin{tabular}{|c|c|c|c|c|}
\hline $\begin{array}{l}\text { YEAR } \\
1975 \\
1980 \\
1985 \\
1990 \\
2000 \\
2010 \\
2020 \\
2040 \\
2060 \\
2075\end{array}$ & $\begin{array}{l}\text { SET } 1 \\
148.1 \\
180.4 \\
229.8 \\
284.7 \\
339.3 \\
393.7 \\
424.5 \\
479.0 \\
520.2 \\
550.1\end{array}$ & $\begin{array}{l}\text { SET2 } \\
148.1 \\
180.4 \\
229.8 \\
284 . \\
339.3 \\
390.2 \\
413.5 \\
457.6 \\
504.7 \\
544.1\end{array}$ & 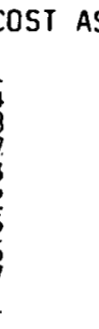 & $\begin{array}{l}\text { SUMP } \\
\text { SE T } \\
148 \\
180 \\
229 \\
284 \\
338 \\
382 \\
407 \\
453 \\
504 \\
544\end{array}$ \\
\hline $\begin{array}{c}T 0_{0 \%} 1975 \\
5 \% \\
10 \% \\
15 \%\end{array}$ & $\begin{array}{l}\text { DISCOUNTED } \\
\begin{array}{l}41500.3 \\
5829.7 \\
2465.3 \\
1528.8\end{array}\end{array}$ & $\begin{array}{l}\text { PRESENT } \\
40514.6 \\
5782.5 \\
2461.1 \\
1528.2\end{array}$ & VALUE & $\begin{array}{l}\text { OF } \\
40250 \\
575 \\
2456 \\
152\end{array}$ \\
\hline $\begin{array}{c}\text { TO } 1995 \\
0 \% \\
5 \% \\
10 \% \\
15 \% \\
15 \%\end{array}$ & $\begin{array}{r}36941.8 \\
8073.7 \\
3979.3 \\
2669.9\end{array}$ & $\begin{array}{r}35956.1 \\
7948.4 \\
3950.9 \\
2660.6\end{array}$ & & $\begin{array}{r}3565 \\
786 \\
39 \\
264\end{array}$ \\
\hline $\begin{array}{c}\text { T0 } 2010 \\
0 \% \\
5 \% \\
10 \% \\
15 \%\end{array}$ & $\begin{array}{r}31673.8 \\
8931.5 \\
4652.8 \\
3179.6\end{array}$ & $\begin{array}{r}30697.9 \\
8682.4 \\
4547.2 \\
3119.1\end{array}$ & & $\begin{array}{r}304 \\
85 \\
44 \\
30\end{array}$ \\
\hline $\begin{array}{c}\text { TO } 2020 \\
0_{\%}^{\%} \\
5 \% \\
10 \% \\
10 \%\end{array}$ & $\begin{array}{r}27586 \\
9166 \\
4945 \\
3402\end{array}$ & $\begin{array}{r}26676 \\
8844 \\
4777 \\
3292\end{array}$ & & $\begin{array}{r}265 \\
87 \\
47 \\
32\end{array}$ \\
\hline
\end{tabular}

HEALTH \& ENVIRON - EMISSIONS \& EFFECTS

\begin{tabular}{|c|c|c|c|c|c|c|}
\hline $\begin{array}{l}\text { YEAR } \\
1975 \\
1980 \\
1985 \\
1990 \\
2000 \\
2010 \\
2020 \\
2040 \\
2060 \\
2075\end{array}$ & $\begin{array}{l}\text { POP EXP } \\
\text { E3 } \\
\text { MAN REM } \\
14.31 \\
43.47 \\
90.99 \\
184.95 \\
207.63 \\
221.40 \\
230.31 \\
234.90 \\
234.90 \\
234.90\end{array}$ & $\begin{array}{r}\text { KR-85 } \\
\text { E6 } \\
\text { CURIES } \\
13.04 \\
39.61 \\
82.90 \\
168.26 \\
186.22 \\
140.22 \\
111.44 \\
17.22 \\
7.38 \\
.00\end{array}$ & $\begin{array}{r}\text { TRIT } \\
\text { E5 } \\
\text { CURIES } \\
4.66 \\
14.17 \\
29.66 \\
60.21 \\
66.81 \\
54.24 \\
46.38 \\
19.20 \\
16.33 \\
14.18\end{array}$ & $\begin{array}{c}\text { RAD WASTE } \\
\text { E3 } \\
\text { CU FT } \\
2.92 \\
8.86 \\
18.54 \\
37.62 \\
41.64 \\
31.35 \\
24.92 \\
3.85 \\
1.65 \\
.00\end{array}$ & $\begin{array}{r}\text { SPENT } \\
\text { BLANKEI } \\
\text { E3 COU FT } \\
0.00 \\
0.00 \\
0.00 \\
.55 \\
6.60 \\
137.50 \\
220.00 \\
440.00 \\
462.00 \\
478.50\end{array}$ & $\begin{array}{l}\text { (SPARE) } \\
\\
0.00 \\
0.00 \\
0.00 \\
0.00 \\
0.00 \\
0.00 \\
0.00 \\
0.00 \\
0.00 \\
0.00\end{array}$ \\
\hline $\begin{array}{l}\text { YFAR } \\
1975 \\
1980 \\
1985 \\
1990 \\
2000 \\
2010 \\
2020 \\
2040 \\
2060 \\
2075\end{array}$ & $\begin{array}{c}\text { CO2 } \\
\text { E9 TONS } \\
5.67 \\
6.14 \\
6.96 \\
7.27 \\
7.11 \\
6.97 \\
7.00 \\
7.00 \\
7.01 \\
7.01\end{array}$ & $\begin{array}{c}\text { CO } \\
\text { E6 TONS } \\
8.92 \\
8.56 \\
9.56 \\
10.16 \\
10.40 \\
10.04 \\
10.34 \\
10.40 \\
10.40 \\
10.40\end{array}$ & $\begin{array}{c}\text { NOX } \\
\text { E6 TONS } \\
18.08 \\
19.92 \\
22.87 \\
23.78 \\
23.22 \\
22.78 \\
22.76 \\
22.75 \\
22.76 \\
22.76\end{array}$ & $\begin{array}{c}\text { SO2 } \\
\text { E6 TONS } \\
14.12 \\
15.90 \\
19.04 \\
20.50 \\
19.97 \\
20.00 \\
19.97 \\
19.92 \\
19.93 \\
19.93\end{array}$ & $\begin{array}{c}\text { PART } \\
\text { E6 TONS } \\
8.36 \\
9.36 \\
11.61 \\
14.23 \\
14.34 \\
15.49 \\
15.69 \\
15.58 \\
15.60 \\
15.60\end{array}$ & $\begin{array}{c}\mathrm{HC} \\
\text { E6 } \mathrm{TONS} \\
2.73 \\
2.83 \\
3.12 \\
3.15 \\
2.94 \\
2.74 \\
2.75 \\
2.75 \\
2.75 \\
2.75\end{array}$ \\
\hline $\begin{array}{l}\text { YEAR } \\
1975 \\
1980 \\
1985 \\
1990 \\
2000 \\
2010 \\
2020 \\
2040 \\
2060 \\
2075\end{array}$ & $\begin{array}{c}\text { LAND USE } \\
\text { E6 ACRES } \\
14.17 \\
17.00 \\
20.82 \\
25.48 \\
27.75 \\
28.95 \\
29.56 \\
29.83 \\
29.84 \\
29.84\end{array}$ & $\begin{array}{c}\text { DEA IHS } \\
\text { E3 } \\
1.14 \\
1 . .48 \\
1.76 \\
2.07 \\
2.31 \\
2.49 \\
2.53 \\
2.52 \\
2.52 \\
2.52\end{array}$ & $\begin{array}{l}\text { INJURIES } \\
\text { E3 } \\
26.12 \\
33.37 \\
40.54 \\
49.93 \\
59.22 \\
64.76 \\
66.35 \\
66.24 \\
66.24 \\
66.18\end{array}$ & $\begin{array}{c}\text { MAN DAYS } \\
\text { LOST EG } \\
1.71 \\
2.20 \\
2.65 \\
3.20 \\
3.72 \\
4.05 \\
4.14 \\
4.13 \\
4.13 \\
4.13\end{array}$ & $\begin{array}{c}\text { SOLID WASTE } \\
\text { E9 TONS } \\
.20 \\
.26 \\
.32 \\
.38 \\
.45 \\
.47 \\
.48 \\
.47 \\
.47 \\
.47\end{array}$ & \\
\hline
\end{tabular}

Figure D-19. Continued. 